\title{
Irish Catholic Voluntary Associations in the Canadian Liberal Order, 1840-1882
}

by

\author{
Mike McLaughlin
}

A thesis submitted to the Faculty of Graduate and Postdoctoral Affairs in partial fulfillment of the requirements for the degree of

Doctor of Philosophy

in

History

Carleton University

Ottawa, Ontario

(C) 2016

Mike McLaughlin 


\begin{abstract}
$\underline{\text { Abstract }}$
This study will explore the ways in which Irish Catholic voluntary associations engaged with the Canadian liberal order in the nineteenth century by focusing especially on three specific associations that were formed at particular times to confront particular social problems: temperance societies, the Catholic League, and Home Rule branches. Some organizations opposed liberalism and the liberal state, while others disseminated liberal values. Some, like temperance societies, did both. Informed by Ian McKay's Liberal Order Framework, I have framed the Canadian context within which Irish Catholic voluntary associations functioned in a liberalizing society with a strong attachment to Protestant British identity. In studies focusing on state formation, democracy, and liberalism, scholars such as Alan Greer and Ian Radforth, Jeffrey McNairn, and Darren Ferry have positioned mainstream voluntary associations as having had a central role in the development of liberalism and the formation of the Canadian state. This study sets out to examine the extent to which Irish Catholic voluntary associations had a similar function.
\end{abstract}

Research suggests that in some cases Irish voluntary associations resisted the liberal Canadian state through their advancement of Catholic values that challenged state encroachment into the lives of parishioners, demonstrations of a robust collective identity that, though couched in liberal terms, emphasized ethno-religious difference, and objections to illiberal techniques of governing by British authorities such as the land tenure system in Ireland and the suspension of legal due process both there and in Canada. Yet in other significant ways the organizations under review in this study contributed to the development of liberal British Canada by promoting principles of self-government, participating in the solidification of the liberal Canadian state, and casting their own Irish nationalism in liberal 
terms. By the time the Canadian Parliament passed resolutions in support of Irish Home Rule in 1882, a liberal consensus was emerging between Canadian Irish Catholics and the Canadian liberal order on the issue of Irish self-government, thus forcing promoters of liberalism in Canada to allow a greater level of pluralism than they wanted, albeit on thoroughly liberal terms. 


\section{$\underline{\text { Acknowledgments }}$}

This dissertation is truly a collaborative effort. I would like to thank the members of my examination committee, Bruce Elliott, Mark McGowan, Leighann Neilson, Karen March, Dominique Marshall, and John Walsh, who all generously provided thoughtful advice and insights on how to improve this work. I need to extend a special thank you to my adviser Bruce Elliott for his tireless work on this project, without which this work would not have been possible. I would also like to acknowledge and thank the staff, faculty, administration, and my colleagues in the Department of History at Carleton University who on daily basis create a warm, encouraging, yet academically demanding atmosphere, which fosters advanced scholarship in a supportive environment.

Funding for this project was generously provided by Carleton's Department of History, the Faculty of Arts and Social Sciences, and the Faculty of Graduate Studies and Postdoctoral Affairs. In addition to departmental funding, I was aided by Shannon Scholarships in Social History, as well as Teaching Assistantships.

My friends and family went along with me on this dissertation ride and our conversations (that were not necessarily conducted on temperance principles) helped me express and clarify some of the ideas on these pages. My partner Wei Lin Wang was patient and supportive as I worked on this project, and throughout my many freak-outs as I assembled the various scraps of paper that I "wrote something important on" and knew I "put somewhere, but I can't remember where." 
Table of Contents

Abstract

Acknowledgements

Table of Contents

List of Tables

List of Appendices

viii

I. Liberalism, State Formation, and Irish Catholic Voluntary Associations 1

Definitions, Social Functions, and Ethnicity

Voluntary Associations and the New Political History:

State Formation and The Liberal Order in the British World 8

Chapters and Argument

II. The Illiberalism of Ultramontanism and the Struggle for Acceptance

Introduction

The Rise and Impact of Ultramontanism

Anti-Catholicism and Community Responses

51

Membership and Leadership of Irish Catholic Voluntary Societies

58

Conclusions

III. Irish Catholic Clergy and Catholicism in the Temperance Crusade

Introduction

Irish Catholics in the Global Temperance Movement

71

Moral Suasion Versus the Power of the State

80

Protestant and Catholic Temperance: Two Solitudes

85

National and Global Catholic Temperance Organizations 92

Conclusions

IV. Irish Catholic Lay Temperance:

Membership, Leadership, Class, and Values $\quad 107$

Introduction

Voluntary Associations and the Middle Class

Class Identity and Values in Irish Catholic Temperance Societies

Elites in the Irish Catholic Temperance Movement

Working-Class Irish Catholics in Temperance Societies

Liberal Individualism and Occupational Self-Interest

Conclusions

\section{Performing Gender and Ethnicity in Irish Catholic Temperance}

Irish Catholic Temperance and the Self-Regulating Male Subject

The Complementarity of Catholic Masculinity and Femininity in the Liberal Order 
VI. The Fenian Challenge and the Defence of the Liberal Order

The Fenian Challenge to the Irish Place in Canada's Liberal Order

The Radical Nationalist Response in Defence of a Liberal Order

Radical Irish Nationalism and the Liberal Order

Patrick Boyle, Peter O'Leary: Settler Colonialism in the Liberal Order J.L.P. O'Hanly: Settler Colonialism and the Liberal Order Conclusions

VII. The Catholic League and the Liberal State

Politics and Patronage

The Catholic League, the Liberal Party and the Push for Unity

Systemic Discrimination and a Liberal Govermentality

Political Fractures Within the Irish Catholic Community

258

Conclusions

VIII. Home Rule and Striving for a Liberal Consensus 272

Introduction 272

Irish Home Rule in the Canadian Liberal Order 276

Parnell, the Land League, and the Radicalization of Irish Home Rule 284

Parnell and the Land League in Canada 286

Parnell's Arrest and the Defence of Legal Liberalism 297

Organizing the Home Rule Resolutions 306

Costigan Introduces the Resolutions 311

The Liberal Language of the Resolutions 315

Political Compromise and the Place of Irish Catholics

in the Liberal State $\quad 320$

Conclusions $\quad 325$

$\begin{array}{ll}\text { IX. Conclusions } & 327\end{array}$

$\begin{array}{ll}\text { Bibliography } & \mathbf{3 6 0}\end{array}$ 
$\underline{\text { List of Tables }}$

Table 2.1 Irish Catholics in Biographical Dictionaries 


\section{List of Appendices}

Appendix A: The 1882 Home Rule Resolutions

Appendix B: Seal of the Montreal St Patrick's Total Abstinence Society

Appendix C: Officers of Irish Catholic Voluntary Associations

in Montreal, 1842-1880

Appendix D: Officers of Irish Catholic Voluntary Associations in Ottawa, 1864-1880

Appendix E: Officers of Irish Catholic Voluntary Associations in Toronto, 1843-1877

Appendix F: Officers of Irish Catholic Voluntary Associations in Halifax, 1871-1880

Appendix G: Officers of Irish Catholic Voluntary Associations in Quebec City, 1871

Appendix H: Officers of Irish Catholic Voluntary Associations in Hamilton, 1869-1876

Appendix I: Officers of Irish Catholic Temperance Societies in Montreal, 1845-1880

Appendix J: Officers of Irish Catholic Temperance Societies in Ottawa, 1864-1880

Appendix K: Officers of Irish Catholic Temperance Societies in Halifax, 1871-1880 
Chapter One: Liberalism, State Formation, and Irish Catholic Voluntary Associations

David Wilson argues that the Irish in nineteenth-century Canada are best understood as a charter group that helped to establish the dominant society to which later immigrants would have to adjust. ${ }^{1}$ Wilson observed that because during the half-century before Confederation, English-speaking Canada was a highly malleable cultural entity, the Irish did more than adapt to Canadian patterns; they actually helped to define and shape those patterns. ${ }^{2}$ This study will trace the ways in which the Irish defined and shaped Canadian cultural patterns by examining the role Irish Catholic voluntary associations played in the development of nineteenth-century liberal British Canada. This study will cover the period from just after the Rebellions and the establishment of Responsible Government—which Ian McKay has argued was the era when the construction of the liberal state began - to the formation of Home Rule associations, the emergence of a liberal consensus between Canadian Irish Catholics and the Canadian state, and the passage of the Home Rule Resolutions by the Canadian Parliament in 1882. The development of the Canadian state in the nineteenth century as a broadly liberal and British entity has become a major study area. Canadian historians have employed numerous models to explore this evolution, from the colony to nation framework through to studies that employ a liberal governmentality paradigm. In recent incarnations of such studies, from Allan Greer and Ian Radforth's seminal state formation study Colonial Leviathan to Jeffrey McNairn's examination of democracy and the public sphere, as well as Darren Ferry's exploration of the liberal order framework, voluntary associations have been viewed as everything from instruments of bourgeois hegemony to training grounds for democratic discourse in a Canadian state dominated by liberalism,

1 David A. Wilson, The Irish in Canada, Canadian Historical Association Booklet: Canada's Ethnic Groups (Ottawa: Canadian Historical Association, 1989), 20.

$2 \quad$ Ibid., 14. 
Protestantism, and British identity. ${ }^{3}$ These studies have neglected Irish Catholic voluntary associations. This dissertation, then, will attempt to write Irish Catholics and Irish Catholic voluntary associations into the political culture of nineteenth-century Canada by exploring the ways in which they both participated in and challenged the formation of a liberal British Canada.

\section{Definitions, Social Functions, and Ethnicity}

During the nineteenth century voluntary associations were widespread, and since then there have been a plethora of studies examining the nature of these organizations. Yet what exactly constitutes a voluntary association has proven difficult for scholars to determine. Constance Smith notes that voluntary associations have been classified according to their size, their internal political structure, their independence of or dependence on outside control, their societal functions, the source of their support, their location, the class and other characteristics of their members, and the intimacy of contact among members. ${ }^{4}$ A succinct theory of organizations evades scholars, leading Smith and Anne Freedman to note the lack of a grand, all encompassing, and generally accepted theory of voluntarism. In the preface to a 1972 study on voluntary associations and their functions in the lives of individuals and social systems, Freedman observed their diffuse nature, remarking that when studying them it is difficult to strictly adhere to a definition since to do so would mean omitting important studies and data based on slightly different concepts of the voluntary association. ${ }^{5}$

3 Allan Greer and Ian Radforth, Colonial Leviathan: State Formation in Mid-nineteenth-century Canada, (Toronto: University of Toronto Press, 1992); Jeffrey McNairn, The Capacity to Judge: Public Opinion and Deliberative Democracy in Upper Canada, 1791-1854, (Toronto: University of Toronto Press, 2000); Darren Ferry, Uniting in Measures of Common Good: The Construction of Liberal Identities in Central Canada, 1830-1900, (Montreal and Kingston: McGill-Queen's University Press, 2008).

4 Constance Smith and Anne Freedman, Voluntary Associations: Perspectives on the Literature (Cambridge: Harvard University Press, 1972), 2.

5 Smith and Freedman, Voluntary Associations, vii. 
An early descriptive attempt, put forth by Samuel Johnson in 1755, defined voluntary associations as "an assembly of good fellows meeting under certain conditions." Since then this definition has been refined and nuanced, but the essential expansiveness of Johnson's definition remains. Some definitions concentrate on the social and cultural aspects of voluntary associations. Bernard Berelson and Gary A. Steiner defined them not as political groups, but as organizations functioning in civil society "that people belong to part time and without pay, such as clubs, lodges, good-works agencies and the like." In his article on "Voluntary Associations" in the 1968 edition of the International Encyclopedia of the Social Sciences, David Sills put forth a similar definition of voluntary associations as "spare-time, participatory associations." " In a 1965 review of British and American research on voluntary associations, Raymond Morris conceived of voluntary associations as "groups in which membership is in no sense obligatory, which have a formal constitution" but do not have paid officials at the local level. ${ }^{9}$ In his research on voluntary associations in history, Jack C. Ross defined them as "an organization of people who participate without coercion or direct profit." Smith and Freedman see voluntary associations as non-profit, non-government, private groups in which individuals join by choice. Members, they continue, "are not born into such associations as they are into the family or the church, nor drafted into them as in the case with the military, nor are they required to join in order to make a living as is frequently true of unions and professional groups." ${ }^{11}$ Another useful definition of the

6 Samuel Johnson, A Dictionary of the English Language, 2 Vols. (London: W. Strahan, 1755) in Jack C. Ross, An Assembly of Good Fellows: Voluntary Associations in History (Westport, Connecticut: Greenwood Press, 1976), 5.

7 Bernard Berelson and Gary A. Steiner, Human Behaviour: An Inventory of Scientific Findings (New York: Harcourt, Brace, 1964), 364.

8 David Sills, "Voluntary Associations: Sociological Aspects," in International Encyclopedia of the Social Sciences, Volume 16, ed. David Sills (New York: Macmillan and Free Press, 1968), 363.

9 Raymond Morris, "British and American Research on Voluntary Associations: A Comparison," Sociological Inquiry, 35 (Spring 1965): 186-7.

10 Ross, An Assembly of Good Fellows, 6.

11 Smith and Freedman, Voluntary Associations, viii. 
expansive term "voluntary association" was put forth by Robert T. Anderson, who contended that voluntary associations are "formally constituted groups bound primarily by ties of shared interest rather than kinship or coresidence."12

Political scientists have explored the democratic functions of voluntary associations. Thomas Hobbes viewed groups and factions as threats to the state, as did Madison in the Federalist Papers..$^{13}$ This view was held by political scientists Carl Friedrich and Zbigniew Brzezinski in their analysis of totalitarian regimes. Friedrich and Brzezinski defined a totalitarian regime in part by the existence of a central control which has direction of the entire economy "through the bureaucratic coordination of formerly independent corporate entities, typically including most associations and group activities." ${ }^{14}$ Arnold Rose likewise saw voluntary associations in terms of their democratic functions, arguing that they support political democracy by distributing power over social life among a large proportion of the citizenry, which provides a sense of "satisfaction with modern democratic processes because they help the ordinary citizen to see how the processes function in limited circumstances, of direct interest to himself." ${ }^{15}$

Political scientists have generally viewed voluntary associations as constitutive elements of the modern liberal democratic state. But in writing of the 1970s, Stuart Langton discussed a renaissance of voluntarism in America. ${ }^{16}$ This "new volunteerism" arose from a sense of alienation from the bureaucratic, centralizing, and depersonalized features of

12 Robert T. Anderson, "Voluntary Associations in History," American Anthropologist LXXIII (February 1971): 219.

13 Smith and Freedman, Voluntary Associations, vii.

14 Carl J. Friedrich and Zbigniew K. Brzezinski, Totalitarian Dictatorship and Autocracy (Cambridge: Harvard University Press, 1965), 22.

15 Arnold Rose, Theory and Method in the Social Sciences (Minneapolis: University of Minnesota Press, 1954), 51.

16 Stuart Langton, "The New Voluntarism," Nonprofit and Voluntary Sector Quarterly 10, no. 1 (January 1981): 7. 
contemporary government and business. ${ }^{17}$ Scholars of ethnicity, religion, and immigration probed the ways in which voluntary associations impacted the integration of immigrants into the receiving society, mirroring Langton's point about the voluntary association as an antidote to the alienation of modern societies and applying it to ethnic studies. ${ }^{18}$ Ethnic voluntary organizations were formed along ethno-religious lines, and their constitutions and bylaws specified ethnic or religious qualifications for membership. ${ }^{19}$ These organizations became important social and cultural gathering places for immigrants and their descendants as they attempted to adjust in their new homes.

In his dissertation "Voluntary Associations and Social Structure" Sherwood Fox distinguished three varieties of voluntary associations. One type was majoral, which includes business, professional, and educational associations and served the interests of the major institutions of society. Fox also defined medial voluntary associations, which includes veterans' groups and social service organizations that mediate between major segments of society. Fox referred to ethno-religious voluntary associations as "minoral" voluntary associations, which served the interests of significant minorities in the population. ${ }^{20}$ Gunnar Myrdal explored African American voluntary associations in his 1940 An American Dilemma and found that African Americans were more likely to join associations than were whites of comparable class status. Myrdal argued that the higher rates of African American participation was a compensating behaviour making up for African American exclusion from many other aspects of American society. ${ }^{21}$ This point, later articulated by Langton, has

17 Ibid., 9.

18 Paul Florin, Eric Jones, Abraham Wandersman, "Black Participation in Voluntary Associations," Nonprofit and Voluntary Sector Quarterly, vol. 15, no. 1, (January 1986): 65.

19 For a representative example of these rules see The Constitution and By-laws of the Irish Catholic Benevolent Society of Quebec. Canadian Institute for Historical Microreproductions (CIHM) 57777.

20 Sherwood Dean Fox, "Voluntary Associations and Social Structure" (PhD diss., Harvard University, 1952). Referenced in Smith and Freedman, Voluntary Associations, 3.

21 Gunnar Myrdal, with the assistance of Richard Sterner and Arnold Rose, An American Dilemma: Two Volumes (New York: Harper, 1940), 984-985; Smith and Freedman, Voluntary Associations, 164. 
become an accepted part of the literature on ethnic voluntary associations of all kinds. For instance, John D. Hutcheson Jr., and Lino H. Dominguez argue that traditional ethnic selfhelp organizations have often been successful in facilitating access to needed services in areas where ethnics have resided in dense clusters. ${ }^{22}$

Myrdal's research laid out a fundamental question relating to the extent to which minority racial or ethno-religious voluntary associations serve as alternatives to mainstream society, or are a part of a pluralistic society. Moreover, with respect to immigrant ethnic voluntary associations, a key issue is the extent to which these organizations facilitate or retard the integration of immigrants. Sills, for instance, has argued that ethnic voluntary associations help integrate minority groups into the larger society. ${ }^{23}$ Likewise, Mary Treudly found that Greek associations in Boston aided in the "Americanization" of the groups' members. Treudly found that they cushioned the shock of transition to a new society, offered incentives for adapting to that society, provided a setting in which to practice American behaviour and leadership techniques, and also articulated a group consensus with respect to the choice of cultural patterns. ${ }^{24}$ Alternatively, Helen Znaniecki Lopata found that voluntary associations within the Polish community of Chicago slowed the rate of integration of members. These organizations, Lopata concluded, helped preserve the ethnic community as a distinct entity owing to the primary function of these organizations as an "in-group statusshifting device" for members, with emphasis on developing outgroup recognition of Polish culture. Part of this process, Lopata argued, necessitated education and cultural activities directed toward the preservation of certain positively evaluated aspects of Polish culture,

22 John D. Hutcheson Jr., and Lino H. Dominguez, "Ethnic Self-Help Organizations in Non-Barrio Settings: Community Identity and Voluntary Action," Nonprofit and Voluntary Sector Quarterly. 15, no. 4, (October 1986): 13.

23 Sills, "Voluntary Associations," 372-6.

24 Mary Bosworth Treudly, "Formal Organization and the Americanization Process with Special Reference to the Greeks of Boston," American Sociological Review 14 (February 1949): 44. 
thus reinforcing Polish Americans as a unified group rather than integrated Americans. ${ }^{25}$

Among immigrants in nineteenth-century Canada, Irish Catholics had a robust associational life, and the issues laid out by Langton, Myrdal, Treudly and Lopata were manifest therein. Brian Clarke has argued that the renewal of the Catholic Church resulted in the emergence of a wide variety of parochial associations dedicated to advancing Catholic principles. ${ }^{26}$ While indeed many Irish organizations were under clerical control, there also existed a substantial amount of lay initiative in these associations.

I argue that Irish Catholic voluntary associations functioned in three interconnected ways: spaces controlled by the Church aimed at instilling ultramontane principles in members and intended to construct a parallel Catholic subculture; adaptive mechanisms for Irish Catholics, in which members could define and prescribe class values and ethnic identity and assert a widespread sense of common identity; and vehicles for social change, emerging in response to specific conditions in Canada and utilized by middle-class Irish Catholics to achieve cultural integration or acceptance. The mode of operation of middle-class Irish Catholic voluntary associations reflected the changing democratic and bureaucratic techniques that accompanied modernity and urban-industrial growth. Structurally, these associations can be classified as "rational-legal." Such associations, according to Anderson, possess "written statutes clearly defining the membership, participant obligations, leadership roles. ${ }^{27}$ Although they were organized along ethno-religious lines, Irish Catholic voluntary associations did not aim to recreate the Old World but to secure rights in the New World. They fought to secure rights for the community, whether that be the right to control their

${ }^{25}$ Helen Znaniecki Lopata, "The Functions of Voluntary Associations in an Ethnic Community: 'Polonia'," in Contributions to Urban Sociology, ed. Ernest W. Burgess and Donald J. Bogue (Chicago: University of Chicago Press, 1964), 203.

26 Brian Clarke, Piety and Nationalism: Lay Voluntary Associations and the Creation of an Irish-Catholic Community in Toronto, 1850-1895, (Montreal \& Kingston: McGill-Queen's University Press, 1993), 4.

27 Anderson, "Voluntary Associations in History," 215. 
own affairs or the right to seek integration on equal terms. They were social units that acted as intermediaries between the individual and society, and were established to confront specific issues that affected the Canadian Irish Catholic community. While each had different social functions, they were linked through common membership of the middle to lower middle-classes who lacked inherited status and sought advancement in Canadian society partly through participation in these societies.

Voluntary Associations and the New Political History: State Formation and The Liberal

\section{Order in the British World}

Another focus of research explored voluntary associations as spaces within which citizens were constructed. In a 1990 article, Virginia A. Walter outlined the ways in which youth voluntary associations trained children to be citizens in a democratic state. Viewing children as "the adult citizens of tomorrow," Walter found that participation in youth service organizations was more potent in transferring knowledge, values, and skills necessary for citizenship, civic awareness, and participation in democratic institutions than either television or formal education. ${ }^{28}$ While Walter explored voluntary associations through the political scientific lens of democratic functions, her focus on non-state institutions and employment of a "citizen-in-training" framework was representative of the new political history and the rise of state formation studies that occurred throughout the 1980s and 1990s. ${ }^{29}$ Not the kind of political histories associated with the great man narrative, new political history was instead a broad study of the processes, agencies, and institutions that facilitated the widening reach of the state in the mid-nineteenth century. As Allan Greer and

28 Virginia A. Walter, "Children as Citizens in Training: Political Socialization for s Strong Democracy," Nonprofit and Voluntary Sector Quarterly, vol. 19, no. 1 (Spring 1990): 7.

29 The classic example of this approach is Philip Corrigan and Derek Sayer, The Great Arch: English State Formation as Cultural Revolution, (Oxford: Basil Blackwell Inc., 1985). 
Ian Radforth note in the introduction to Colonial Leviathan, traditional political histories focused almost wholly on government policies and the legislature leading to a narrow focus on "the competition for power and high office" within a "restricted circle of actors representing different social interests and enunciating conflicting political philosophies." ${ }^{30}$ The state within which these contests for power occurred was assumed, rather than studied. The new political history, by contrast, aimed to explore the edifice of the state through a "broader conception of political power" than the executive and legislature. ${ }^{31} \mathrm{~A}$ critical perspective on state formation emerges in the work of Bruce Curtis. Though he does not probe voluntary associations so much as state agencies, he has explored the growth of a broad framework of liberal government, which he argues worked in part through a series of inclusions and exclusions, and by the demarcation of the civilized from the uncivilized, served the interests of dominant social classes. ${ }^{32}$

Within this paradigm, voluntary associations became an important avenue through which to study mid-nineteenth-century society. Jeffrey McNairn's view on the place of voluntary associations echoed the political scientific view of Walter, who explored voluntary associations as non-state institutions that acted as training grounds for democracy. In voluntary associations, McNairn wrote, "people learned and practised the norms of reasoned discussion and mutual respect vital to sustained public deliberation." ${ }_{33}$ McNairn viewed voluntary associations as spaces in which individuals were trained in democratic principles and rational debate. ${ }^{34}$ He argued that voluntary associations allowed members to "develop

30 Greer and Radforth, Colonial Leviathan, 4.

31 Ibid., 2.

32 Bruce Curtis, “After 'Canada': Liberalisms, Social Theory, and Historical Analysis,” in Liberalism and Hegemony: Debating the Canadian Liberal Revolution edited by Jean-Francois Constant and Michel Ducharme, (Toronto: University of Toronto Press, 2009), 186.

33 Jeffrey McNairn, The Capacity to Judge: Public Opinion and Deliberative Democracy in Upper Canada, 1791-1854, (Toronto: University of Toronto Press, 2000), 63.

34 Ibid. 
the requisite skills, expectations, and sociability for political deliberation," ${ }^{35}$ which meant that colonial elites could no longer claim a "monopoly on the ability to organize or to reason effectively in public." ${ }^{36}$ Yet, he argues, opportunities to participate in these organizations were not equal. "Informal constraints and formal prohibitions," McNairn argued, "minimized the opportunities of the most economically marginal to participate in associational life." 37 Those deemed not to have "the capacity to judge," he argued, included those who "lacked the independence to exercise their reason in public and the time, skills, and resources to contribute to common projects." 38 Thus, McNairn argues that in spite of the fact that voluntary associations were "experiments in democratic sociability," 39 they nonetheless advanced hegemonic perspectives on who could have access to the public sphere and who would be excluded therefrom.

The work of Greer and Radforth likewise presents voluntary associations in the modern, liberal state as institutions of coercion that normalized the rule of a minority. Greer and Radforth see voluntary associations, and the way in which they spread a social and class system throughout society, as tools to advance dominant social classes. They argue that while trade associations, literary and scientific societies, and religious groups were widespread, the most significant type of voluntary associations were the philanthropic/social-reform organizations. In these organizations, people joined together to "succour the poor and infirm, to establish hospitals and clinics, to press for more humane and effective treatment of criminals, and to urge drinkers to shun the bottle." ${ }^{40}$ The actions of these associations, argue Greer and Radforth, almost invariably implied an extension of

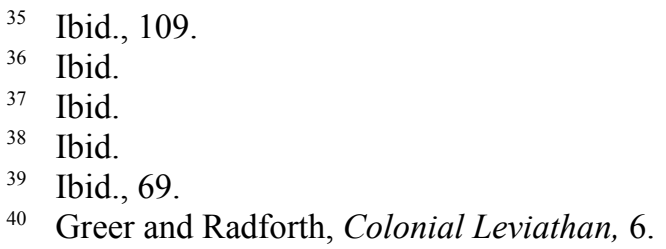


supervision and regulation; the rich and privileged were finding new ways to meddle in the lives of the poor and dependent, all in the interests of "social peace and security." The work of McNairn and Greer and Radforth on the function of voluntary associations illustrates that voluntary associations were institutions controlled by the powerful in society to inculcate what they viewed as appropriate values in members. Liberal democracy legitimized and normalized the rule of powerful leaders.

An influential thesis in the literature of cultural state formation in the liberalizing era has been Ian McKay's Liberal Order Framework. McKay argued that between 1840 and 1900 Canada underwent a liberal revolution in which possessive individualist liberalism became the hegemonic principle of social organization in the place of the collectivist and authoritarian ancien regime. ${ }^{42}$ McKay was taking the idea of the "bourgeois revolution" and applying it to Canadian historiography, arguing that it was through various state measures that liberalism was extended. McKay's critical perspective on this process separates his view sharply from earlier scholars who celebrated the advent of responsible government and other milestones on the road to Canadian liberal democracy and independence. McKay illustrated how this celebration became a dominant discourse and highlighted exclusions from the liberal order.

McKay's framework has garnered much attention among Canadian historians, and it has been lauded and criticized in equal measure. ${ }^{43}$ Nancy Christie has critiqued McKay's Liberal Order Framework for neglecting the role of voluntary associations in Canada's nineteenth-century "liberal" revolution. ${ }^{44}$ In her review of the liberal order framework,

41 Ibid.

42 Ian McKay, "The Liberal Order Framework: A Prospectus for a Reconnaissance of Canadian History," Canadian Historical Review 81, no. 4 (2000): 621.

43 For instance, see the essays in Jean-Francois Constant and Michel Ducharme eds., Liberalism and Hegemony: Debating the Canadian Liberal Revolution, (Toronto: University of Toronto Press, 2009).

44 Nancy Christie, "Revisiting Canada's Project of Liberal Rule, The Underhill Review (Fall 
Christie argued that McKay gives too much credit to the Canadian state for transmitting liberal, middle-class values across society, considering the relative weakness of the Canadian state at that juncture. Rather than positioning the state as the vehicle through which liberal, middle-class ideals emerged and were extended in Canada, Christie asserted that scholars ought to explore associational life in organizations such as temperance societies, mechanics institutes, and similar voluntary associations where individuals who chose to join were exposed to liberal, middle-class values. ${ }^{45}$ In Christie's view, the extension of liberalism and middle-class values is better studied through voluntary associations in civil society than through a state formation framework.

Christie referred to the work of the Canadian historian Darren Ferry, who, in Uniting in Measures of Common Good, explored the history of voluntary associations in central Canada. In a useful introduction to the text, Ferry observed that voluntary associations were established as part of the process of middle-class formation and acted as vehicles through which the agents of emerging industrial capitalism suppressed the working class. Historians have subsequently depicted these organizations as "conscious instruments of middle-class hegemony." ${ }^{46}$ However, Ferry was quick to assert that evidence suggests these organizations were more than simply tools for social control employed by the middle-class over the working classes. For instance, Ferry notes, there was a strong working-class membership in

2009).www3.carleton.ca/underhillreview/09/fall/reviews/christie.htm. Accessed 20 February 2014. McKay does not address the role of voluntary associations in his framework with any depth. Seeing voluntary associations as a product rather than as an instrument, he mentions that the Victorian proliferation of voluntary associations was a product of the liberal freedoms of association and assembly, before moving on to his larger point regarding trade unions who put liberal property rights at risk. Ian McKay, "Canada as a Long Liberal Revolution: On Writing the History of Actually Existing Canadian Liberalisms, 1840s-1940s, in Liberalism and Hegemony: Debating the Canadian Liberal Revolution, edited by Jean-François Constant and Michel Ducharme, (Toronto: University of Toronto Press, 2009), 402.

45 Christie also emphasizes the importance of choice in voluntary associations and the spread of liberal middle-class values, making the point that they were not simply imposed on people by the state but were actively sought out by individuals through their membership in voluntary associations.

46 Ferry, Uniting in Measures of Common Good, 4. 
these organizations. The heterogeneity within voluntary associations, suggests Ferry,

allowed individuals who felt marginalized in colonial society to use voluntary associations to address the "material inequalities inherent in the governing social order and the symbols and representations of that authority." ${ }^{47}$

Ferry has argued that voluntary associations encompassed liberal individualism in the early nineteenth century but that liberal individualism was supplanted by state corporatism in the twentieth century. For Ferry, the shift in liberal notions of community between 1830 and 1900 was from voluntarism and interdependence between classes and the public and private spheres to a liberal conception of community based on the corporate state and bureaucratic expertise. Corporatism, then, swept away the voluntary movement as the nation-state, rather than amateurs in voluntary associations, became seen as the means for the salvation of the citizenry. Many intellectuals, Ferry argues, saw the nation-state as the best means to solve seemingly intractable problems such as class conflict, religious tensions, and ethnic discord. Increased reliance on state measures, particularly in the area of social services in the burgeoning welfare state, meant the end of the popularity of the nineteenth-century voluntary association movement. ${ }^{48}$

Heavily informed by McKay's thesis, Ferry's study is concerned with the role that

47 Ferry, Uniting in Measures of Common Good, 5.

48 Ferry, Uniting in Measures of Common Good, 285-89. The view that the state supplanted voluntary associations in providing services has long been expressed in the literature. In a 1985 article, Mel S. Moyer argued that Canadians have a more left-leaning political philosophy than Americans, and links this to the fact that Canadian rely more on governments and less on voluntary associations to provide social and cultural services. Mel S. Moyer, "Voluntary Action Research: A View From Canada," Nonprofit and Voluntary Sector Quarterly, vol. 14, no. 2-3, (April 1985): 15; Ramsay Cook argues something similar regarding the Social Gospel movement of the early twentieth century. Cook says that the state took control over social welfare and "social reform thought moved from a religious to a social science perspective." Because, Cook argues, the Protestant Churches abandoned theology for improving life on earth, the state's take-over left them devoid of meaning. Cook, though, overstates the degree to which the Churches had abandoned theology as I believe Ferry exaggerates the demise of voluntary organizations. Ramsay Cook, The Regenerators: Social Criticism in Late Victorian Canada, (Toronto: University of Toronto Press, 1985), 5 . 
voluntary associations played in the establishment of the liberal social order in nineteenthcentury Canada, and the way in which the emergent commercial classes employed voluntary associations to combat the strength of the Tory elite. Yet, though he works within the liberal order paradigm, he breaks from McKay's emphasis on the individual as he focuses on a liberal communitarianism that crossed religious and class boundaries. Hence he branded associations that broke apart due to sectarian or class factionalism as having problematic "non-liberal attitudes." ${ }^{49}$ The non-liberal attitudes of associations noted by Ferry were epitomized by the expression of collectivist attitudes and the rights of the collective groupbe they religious, ethnic, or both. ${ }^{50}$ Thus, Ferry omitted religious, political, and ethnic societies from his research. ${ }^{51}$ This gap is surprising and disappointing, as framing voluntary associations as conduits through which individuals within marginalized collectives could address their perceived source of marginalization seems an excellent way to study the role ethnic voluntary associations played in the extension of middle-class values in Canada. Much has been written within historical and sociological literature detailing the role that ethnic voluntary associations played in class and ethnic formation among a specified ethnic group, as well as the role that those organizations played in the evolution of the relationship

49 Ibid, 11.

50 This point is also made in E.A. Heaman, "Rights Talk and the Liberal Order Framework," in Liberalism and Hegemony: Debating the Canadian Liberal Revolution, eds. Jean-François Constant and Michel Ducharme (Toronto: University of Toronto Press, 2009), 163.

51 Gillian Poulter, review of Uniting in Measures of Common Good: The Construction of Liberal Identities in Central Canada, (McGill-Queen's University Press, 2008) by Darren Ferry, Labour/Le Travail 65 (Spring/Printemps 2010): 192-194. Ferry is not alone in this. Despite the influence wielded by the Catholic Church in Irish associational culture, not all scholars place the Church within studies of associational life. In an article on African American voluntary associations, Nicholas Babchuk and Ralph Thompson exclude religious organizations from their analysis. Nicholas Babchuk and Ralph Thompson. "The Voluntary Associations of Negroes," American Sociological Review XXVII (October, 1962): 647-655. Anthony Laying observes that such an exclusion seems arbitrary, especially when Babchuk and Thompson initially assert that in many ways churches and voluntary associations are functional equivalents, yet then go on to claim that equating the Church with other formal voluntary associations would be "spurious." Anthony Layng, "Voluntary Associations and Black Ethnic Identity," Phylon, 39, no. 2 (1978). In the case of Irish Catholic associational life, separating the spiritual from the civic world of associational life seems likewise unnecessary and inaccurate. Catholic theology and practices were prominent as ultramontane clerics came to dominate Irish Catholic voluntary associations. 
between the ethnic group and wider society. ${ }^{52}$ For Ferry, however, the marginalized individuals he referred to were liberals and reformers who seemed solely to be British and American Protestants. By neglecting to include Irish Catholic associational life in the development of liberalism and the dissemination of middle-class values in nineteenthcentury Canada, Ferry's conclusions regarding the history of the relationship between liberalism and voluntary associations overlook a major part of the population and thus omits ethnic diversity within wider Canadian middle-class culture. While Ferry's work is a remarkable piece of scholarship providing insightful and thoughtful analysis into nineteenthcentury society, important voluntary associations were neglected in his study. This dissertation will attempt to fill this gap through an exploration into Irish Catholic voluntary associations that were unabashedly religious, political, and ethnic.

While there is general agreement that something like a liberal revolution took place in nineteenth-century Canada, there has been much less consensus about what liberalism actually means and what form it took in the Canadian context. For McKay, the concept of the individual lies at the heart of the liberal order. ${ }^{53}$ Along similar lines, E.A. Heaman argues that individual political liberties such as habeas corpus are the fundamental principles of liberalism. ${ }^{54}$ By contrast, Bruce Curtis makes the point that liberal individualism was seen by liberal theorists to depend on and advance forms of community. ${ }^{55}$ Darren Ferry also sees community as key to Canadian liberalism, with inclusiveness at its core. ${ }^{56}$ These contrasting

52 Anthony Layng, "Voluntary Associations and Black Ethnic Identity," Phylon, 39, no. 2 (1978): 171; Elizabeth Neswald, “"The Benefits of a Mechanics' Institute and the Blessing of Temperance': Science and Temperance in 1840s Ireland," Social History of Drugs and Alcohol 22, no. 2 (Spring 2008): 209; Lorene Bridgen, "On Their Own Terms: Temperance in Southern Ontario's Black Community, 1830-1860," Ontario History 101, no. 1, (Spring 2009): 64.

53 Ian McKay, "Canada as a Long Liberal Revolution: On Writing the History of Actually Existing Canadian Liberalisms, 1840s-1940s." In Liberalism and Hegemony: Debating the Canadian Liberal Revolution, edited by Jean-François Constant and Michel Ducharme, (Toronto: University of Toronto Press, 2009), 350.

54 Heaman, "Rights Talk and the Liberal Order Framework," 143.

55 Curtis, "After 'Canada,"' 183.

56 Ferry, Uniting in Measures of Common Good, 16-17. 
liberalisms can be reconciled by viewing a liberal community as being made up of liberal, self-governing individuals ${ }^{57}$, which nineteenth-century Irish Catholics were certainly aiming to be. These various aspects of liberalism were invoked at assorted times and will therefore arise throughout the chapters that follow. Disparate notions of nineteenth-century liberalisms can be tied together in English-speaking Canada through their place in a socio-political context in which a Protestantism loyal to the British Empire was the dominant mentality.

The British Conquest of New France in 1760 led to the growth and expansion of British institutions in northern North America. The British government aimed to populate their British North American territories with British subjects. Men who were disbanded from land and sea service were to be placed in spots strategic to the defence of the Empire. ${ }^{58}$ The trend of populating the British colonies in North America with former British soldiers would continue into the nineteenth century. At the end of the Napoleonic Wars in 1815, the British government offered demobilized men 100 acres of land to each private and 50 acres for a family member. They were to take up land in border areas from the maritime colonies to western Canada. ${ }^{59}$

Following the American Revolution in the late-eighteenth century, many Britons in America who remained loyal to the British crown fled north to the British colonies, forever altering the demographics of northern North America and allowing for imperial expansion into Aboriginal lands. Jerry Bannister has observed that the arrival of the Loyalists also engendered a new cultural paradigm in which loyalty to the British Empire became paramount. More than simply opposition to the republic to the south, Bannister argues,

\footnotetext{
57 Michel Foucault, “Governmentality," in The Foucault Effect: Studies in Governmentality, eds. Graham Burchell, Colin Gordon, and Peter Miller, (Chicago: University of Chicago Press, 1991), 87.

58 Helen I. Cowan, British Immigration Before Confederation, Canadian Historical Association Booklets, Canada's Ethnic Groups, (Ottawa: Canadian Historical Association, 1978), 4.

59 Ibid., 5.
} 
Loyalism "drew on emergent British identity that encompassed specific conceptions of social order and monarchism. ${ }^{"}{ }^{60}$ In the nineteenth century, Canada was, of course, a colony, Confederation notwithstanding. In fact, Andrew Smith has argued that the federation of British colonies that occurred between 1867 and 1873 was intended to preserve this status. Smith advanced an economic explanation for the federation of British colonies that occurred between 1867 and 1873. Smith argued that a crisis in British North American investments prompted some of the most important financiers in London with investments in Canada to support the political unification of British North America through the British North American Association, formed in 1862 to lobby the British government toward this end. Following the BNNA's call for colonial union between the British North American colonies, the Colonial Office invited the colonies to consider federation within the British Empire.

Smith argued that politicians in Canada responded favourably to this call and the Charlottetown and Quebec conferences were held. ${ }^{61}$

In addition to the economic links, there also existed cultural links between the Canadian colonies and Britain. In The Sense of Power, Carl Berger argued that “imperialism" was a popular idea among a certain set of powerful Canadian leaders, whose beliefs included "movement for the closer union of the British Empire through economic and military co-operation. ${ }^{62}$ Berger saw late-nineteenth and early-twentieth-century "imperial nationalism" as a form of Canadian nationalism. ${ }^{63}$ Recently, Philip Buckner has been at the forefront of studies on this topic. He and R. Douglas Francis observe that Canadian

60 Jerry Bannister, "Canada as Counter-Revolution: The Loyalist Order Framework in Canadian History, 1750-1840," in Liberalism and Hegemony: Debating the Canadian Liberal Revolution, edited by JeanFrançois Constant and Michel Ducharme, (Toronto: University of Toronto Press, 2009), 103.

61 Andrew Smith, British Businessmen and Canadian Confederation: Constitution Making in an Era of Anglo-Globalization, (Montreal and Kingston: McGill-Queen's University Press, 2008), 3-4.

62 Carl Berger, The Sense of Power: Studies in the Ideas of Canadian Imperialism, 1867-1914, (Toronto: University of Toronto Press, 1970), 3.

63 Ibid., 259. 
historians writing before the Second World War, including George Wrong, W.P.M. Kennedy, and Chester Martin, viewed Canada as a British nation. Following the Second World War, Canada had an emergent independent national identity and confidence regarding the role it could play in international affairs. Indeed, legal transformations such as the first Canadian Citizenship Act in 1947 and the 1949 Act making the Supreme Court of Canada the final court of appeal, rather than the Judicial Committee of the Privy Council, attest to the newfound independence of the Canadian state. In the 1960s, other indications of Canada's detachment from the British World emerged. These included redefinitions of symbolism such as the introduction of a new flag that did not include the Union Jack and making "O Canada" the national anthem. Moreover, increased migration from non-British countries in the mid-twentieth-century altered the demographic profile of the country as less and less of the Canadian population were of British origin. These transformations in Canadian society led A.R.M. Lower to lay out his famous "colony to nation" framework in Canadian history. Lower argued that Canadian political and legal institutions and culture and society changed from an essentially British entity to an independent and strongly centralized Canadian nation-state. ${ }^{64}$

Buckner and Francis argue that in the 1960s and beyond, Canadian historians set out to minimize the impact that ties to Britain had in the development of Canadian society and culture. Challenging this model, Buckner and other scholars have attempted to write the British fact back into Canadian history. ${ }^{65} \mathrm{He}$ writes that Canada, as the largest and most prominent of the self-governing British colonies, was clearly part of the British World "a

64 Arthur R. M. Lower, Colony to Nation: A History of Canada, (Don Mills, Ontario: Longmans Canada Limited, 1946), 328.

${ }^{65}$ In this, Buckner was influenced by a generation of British historians who, beginning in the 1970s studied the nature of British identity. Seminal titles in this literature are J.G.A. Pocock, "British History: A Plea for a New Subject," The Journal of Modern History 47.4 (1975): 601-621; Linda Colley, Britons: Forging the Nation, 1707-1837, (New Haven: Yale University Press, 1992). 
world held together more by a sense of belonging to a shared British culture than by ties of commerce and trade. It was the mass migration of British immigrants to Canada in the nineteenth and early twentieth centuries that ensured that Canada would remain part of a British World well into the twentieth century." ${ }^{\prime 66}$ Thus, be it commercially and economically, as Andrew Smith argues, or because of a sense of shared belonging to British culture spurred on by migration and demographics, as Philip Buckner and R. Douglas Francis assert, nineteenth-century Canada was firmly and loyally a British entity. Britishness, Protestantism, and Loyalism shaped the politics, society, and culture of Canada.

Therefore the liberalisms explored by McKay, Heaman, Curtis, and Ferry, as well as the state formation probed by Greer and Radforth, occurred in a political culture that was firmly linked to the British World. The British Protestant context within which the emergent liberal Canadian state was formed has not been lost on scholars whose own understanding of this context has shaped their research models, most notably by ignoring the role of Irish Catholics and Irish Catholics voluntary associations in their research. This study, then, not only aims to write Irish Catholics into the history of voluntary associations in a liberalizing Canada, but also seeks to write Irish Catholic voluntary associations into the history of the development of British Canada.

\section{Chapters and Argument}

The chapters that follow will focus on three specific Irish Catholic voluntary movements: temperance societies, the Catholic League, and Home Rule and Land League branches, and explore the roles these organizations played in the development of a liberal British Canada in

66 "Introduction", Philip Buckner and R. Douglas Francis in Canada and the British World: Culture, Migration, and Identity edited by Philip Buckner and R. Douglas Francis, (Vancouver: UBC Press, 2006), 3. 
the nineteenth century. The examples of temperance societies, the Catholic League, and Home Rule associations demonstrate the strong place of the Catholic Church and anti-liberal ultramontane values in the Irish community, but also the desire of the striving Irish Catholic middle-classes to achieve respectability as self-governing individuals, and be accepted into wider society. Studying these organizations together will allow us to look for patterns of experience not found if looking at them in isolation. By examining what types of Irish Catholic voluntary associations were formed when, by whom, and for what purposes, we can track the development of the Irish Catholic community in nineteenth-century Canada as well as the role of the community in the formation of liberal British Canada.

The following chapter will explore the increasingly ultramontane and nationalist character of Irish Catholic voluntary associations. Originating as inclusive, ecumenical societies led largely by Anglo-Irish elites, by mid-century they had undergone a process of Catholicization led by ultramontane clerics. At the same time, this period saw the rise of revolutionary societies such as the Irish Republican Brotherhood, and its Canadian counterpart, the Hibernian Benevolent Society. Though not an overtly radical nationalist organization, the HBS nonetheless stirred Protestant anxieties in Toronto and elsewhere in Canada.

The third chapter will explore Irish Catholic temperance associations. Temperance societies were established by the clergy as part of the ultramontane revolution in Catholicism in which the Church was placed as the highest authority and the point around which community activity was to pivot. The illiberal perspective of the Church and its view that the clergy, not the state, should have jurisdiction over the lives of individuals, put the Irish Catholic temperance movement at odds with mainstream temperance advocates and posed a challenge to the Canadian liberal order. But, as Brian Clarke has argued, even in 
organizations established by the clergy the laity could and did gain effective control on occasion. ${ }^{67}$ Chapter Four will thus probe the ways in which these organizations merged Irish nationality and Catholic beliefs with respectability, self-government, and expressions of middle-class values that were a part of the broader nineteenth-century anti-alcohol movement and thus formed a major part of middle-class Irish Catholic associational life that sought respectability and integration. Chapter Five will build upon the drive for respectability by focusing specifically on gender and ethnicity in Irish Catholic temperance. These associations demonstrated both resistance by the clergy to the liberal state, which is the subject of Chapter Three, and a way for striving Irish Catholics to learn and perform liberal values, the subject of Chapters Four and Five.

Ferry argues that the mainstream temperance movement's shift from moral suasion to legislative regulation was a sign of increased state reliance and a veering away from individual voluntarism. I will argue that while Irish Catholic temperance likewise originated with moral suasion principles, unlike the mainstream Protestant movement Irish Catholic temperance advocates rejected full prohibition and remained rooted in a moral suasion approach. This occurred for three reasons. First, the Catholic clergy spearheaded the movement. Ultramontanism and insistence on clerical authority and Catholic community leadership put Catholic temperance advocates at odds with the mainstream Protestant movement's support for state regulated prohibition. Secondly, as a consequence of clerical control, theological arguments regarding why God, rather than the state, should have moral jurisdiction over individuals were advanced by Irish Catholic temperance leaders. Finally, with respect to the middle-class laity who supported Irish Catholic temperance, the rhetoric they employed suggests that they remained wedded to the liberal ethos of individualism that

67 Clarke, Piety and Nationalism, 4. 
Ferry argues dominated the early part of the temperance movement, and the voluntary movement more generally. The confluence of clerical authority and middle-class individualist liberalism meant that Irish Catholic temperance did not look to the state to enact or enforce liquor laws.

Chapter Six will look at how the Fenian Raids of 1866 threatened to undermine the political capital accumulated by self-governing Irish Catholics in the preceding years Some within the community espoused the duty of Canadian Irish Catholics to display their loyalty to Canada. ${ }^{68}$ This group sought to mollify Canadian society in the wake of the Fenian danger by stressing their loyalty to crown and country. Yet there existed another faction, represented by J.L.P. O'Hanly and Patrick Boyle, whose response was more combative. They viewed the negative backlash toward the Irish in the wake of the raids as further proof of the increased level of anti-Irish and anti-Catholic prejudice. In defending their co-religionists and fellowcountrymen from allegations of Fenianism, O'Hanly and Boyle highlighted the inconsistencies in the liberal social order and argued that removing the right of due process subverted legal liberalism.

The Raids, coupled with the perception that growing anti-Irish thought was leading to their exclusion from the liberal order, led to the establishment of the Catholic League, which is the subject of Chapter Seven. ${ }^{69}$ The Catholic League was formed by prominent Irish Catholics in Ontario to combat what they saw as the persistent discrimination faced by Irish

68 The reaction of Thomas D'Arcy McGee to the Fenian Raids was representative of middle-class Irish Catholic response. McGee argued that all Canadians have their duties, but Irish Catholics "have a duty additional to the duty of others. We are belied as a class, we are compromised as a class, by these scoundrels; and as a class we must vindicate our loyalty to the freest country left to Irishmen on the globe." See McGee's letter to the editor of the Canadian Freeman (Toronto) 7 June 1866, p. 2, col. 2.

69 The Irish Canadian (Toronto), 12 October 1872, p. 4, col. 6. In the wake of the Fenian Raids of 1866, the government suspended the Habeas Corpus Act in order to facilitate the arrest of suspected Fenians in Canada. This was seen by many Canadian Irish Catholics as a deliberate attempt to arrest Irish Catholics, whether they were associated with the Fenian movement or not, and cast undue suspicions on the entire Irish Catholic community. 
Catholics, and to advocate for greater political equality. An example of identity politics, the Catholic League sought to establish a coherent Irish Catholic voting block to vote only for their co-religionists in order to ensure a greater number of Irish Catholic representatives in political office, and consequent upon that, appointive patronage positions. Through political activities that sought inclusion in the Canadian state, they were arguing for their rightful position in the liberal order and within the apparatus of the expanding state. Moreover, they argued for this as self-governing individuals and employed the language of liberal "rights talk."

Though the Catholic League did not seek reformation of the governmental or patronage system per se, League members argued that until Orange influence was eradicated and a meritocratic civil service established they needed to vote as a block to press the government for a fair share of appointments. Thus they employed the language of liberalism to demand their inclusion in the liberal state even while proposing the illiberal measure of ethnic block voting. Their elaboration of this argument was a measure of how much public opinion was swinging in the direction of a meritocratic civil service.

The Catholic League sought to convince the state of the legitimacy of their ethnic issues and by doing so to acknowledge their issues as mainstream. Thus, when the Home Rule question emerged Irish Catholics could argue that their point of view on Home Rule had to be accepted as it was in accord with the way the Canadian system operated and with the liberal political values of the Canadian state, and this will be the subject of Chapter Eight. ${ }^{70}$ In the wake of the extension of the Irish Home Rule movement in the 1870 s, and

70 For useful explorations of the Home Rule movement see Alvin Jackson, Home Rule: An Irish History, 1800-2000 (Oxford: Oxford University Press, 2003); Paul Bew, Land and the National Question in Ireland, 1858-1882 (Dublin: Gill \& Macmillan, 1979); Conor Cruise O'Brien, Parnell and His Party, 1880-90 (Oxford: Clarendon Press, 1957); Alan O'Day, Irish Home Rule, 1867-1921 (Manchester: Manchester University Press, 1998). 
furthered by severe distress in Ireland, the Irish Land War of 1878-1881, the creation of the Irish National Land League, and the arrest of Home Rule leader Charles Stewart Parnell by British authorities in 1881, Home Rule associations were established throughout Canada. ${ }^{71}$ Unlike temperance associations or the Catholic League, these organizations were oriented toward Irish affairs. Funds were collected by these organizations, and sent to the main Home Rule branch in Dublin to support this mass political mobilization. ${ }^{72}$ The energy of this movement among Irish Catholics in Canada was so strong that myriad Irish Catholic voluntary associations came together to support an initiative for John Costigan to move resolutions in the House of Commons and Canadian Senate that signified Canadian support for the establishment of Home Rule for Ireland and the end of Irish landlordism. Promoters of the Costigan Resolutions constructed this as a liberal project of extending the internal self-government and freehold land tenure enjoyed in colonial Canada to Ireland. When the British government imprisoned Land Leaguers without trial the supporters of the resolutions denounced this suspension of longstanding legal and political rights as evidence of the illiberality of the liberal British Empire and English tyranny in Ireland. By invoking Canadian precedent and British freedoms the resolutions made this Irish matter a mainstream issue in liberal British Canada and legitimized Irish Catholic ethnic issues. A consensus thus emerged between Irish Catholics and the Canadian liberal order on the issue of Irish Home Rule. Through the Catholic League and Home Rule agitations Canadian Irish Catholics thus played a role in forcing the liberal order in Canada to accept a much greater cultural

71 Rosalyn Trigger, "Clerical Containment of Diasporic Nationalism," in Irish Nationalism in Canada, edited by David A. Wilson (Montreal and Kingston: McGill-Queen's University Press, 2009), 82. On the point regarding middle class involvement in the Home Rule movement in Canada see n. 17, p 209; Peter M. Toner, "The Home Rule League in Canada: Fortune, Fenians, and Failure," Canadian Journal of Irish Studies 15, no. 1 (1989): 7.

72 D.C. Lyne, "Irish-Canadian Financial Contributions to the Home Rule Movement in the 1890s," Studia Hibernica 7 (1967): 182. 
pluralism than it envisioned, and on soundly liberal terms. Promoters of the Costigan Resolutions looked to the liberal Canadian state apparatus to legitimize their ethnic issues.

The resolutions were overwhelmingly supported by Canadian politicians and passed without serious opposition. ${ }^{73}$ The Toronto-based Irish Catholic weekly the Irish Canadian reported that the Costigan Resolutions would forever "remain upon record as the deliberate protest of the people of Canada against English tyranny in Ireland." ${ }^{74}$ More than that, however, the resolutions made this Irish matter a mainstream issue in liberal British Canada and legitimized the concern with Irish independence. By entrenching this distinct and collective measure in the Canadian state, a consensus emerged between Irish Catholics and the Canadian liberal order on the issue of Irish Home Rule. Canadian Irish Catholic liberals thus played a role in forcing the liberal order in Canada to accept a much greater cultural pluralism than it envisioned albeit on soundly liberal terms. ${ }^{75}$

Irish societies displayed collective difference during St Patrick's Day celebrations, collective liberalism (some would say illiberalism) through the Catholic Church's control over the temperance movement, protest against the dominance of Protestantism in the Canadian state through the Catholic League, and protest against illiberal British rule in Ireland. Yet the Irish Catholic voluntary movement also promoted individual, liberal values — such as independence, self-improvement, business efficacy, sober respectability, hard work, and rational leisure activities - that would become dominant in modernizing Canadian society. And Irish Catholics sought access to the burgeoning state apparatus in their efforts to

73 They were called the Costigan Resolutions because they were moved by John Costigan, an Irish Catholic member of Parliament.

74 Irish Canadian (Toronto), 10 August 1882, p. 4, col. 7.

75 A similar argument is made by Robin Jarvis Brownlie regarding the place of aboriginals in the liberal order. Robin Jarvis Brownlie, "A Persistent Antagonism: First Nations and the Liberal Order," in Liberalism and Hegemony: Debating the Canadian Liberal Revolution, edited by Jean-François Constant and Michel Ducharme, (Toronto: University of Toronto Press, 2009), 315. 
amend their social position, and in the process contributed to the liberalization of the state. 
Chapter Two: The Illiberalism of Ultramontanism and the Struggle for Acceptance

\section{Introduction}

This chapter outlines the general evolution of Irish Catholic voluntary associations before and during the period under review, largely in relation to broader trends within Irish Catholicism. Originally non-sectarian associations led primarily by Anglo-Irish elites, by mid-century Irish organizations had undergone a dramatic transformation whereby they increasingly came to identify as Catholic and nationalist.

In a series of lectures in 1860, John Lawrence Power O'Hanly, a prominent Irish Catholic who would later become a leader in the Canadian Irish Catholic associational world, defined Irish national societies as associations or organizations of Irishmen and descendants of Irishmen in a foreign country whose purpose is to commemorate their native land, counsel, direct, and comfort their immigrant fellow-countrymen, and to procure information to direct immigrants to localities where they could obtain employment or land. O'Hanly concluded that associations such as St Patrick's Societies should "form the centre around which the scattering elements that comprise our people should gravitate."1 O'Hanly's view accords with the typical rules and constitution of Irish associations. For instance, the stated purpose of the St Patrick's Society of Quebec, founded in 1836, was to give advice and relief to the natives of Ireland and their descendants and of promoting union among all classes of Irishmen and those of Irish origin in Canada. In light of this mission statement, the society prohibited "all political and religious subjects or discussions." 2 The emphasis on sociability in Irish voluntary associations was common throughout North America. The earliest Irish voluntary association in North America was the Charitable Irish Society of

Constitution of the St Patrick's Society of Quebec, 1836, (Quebec: Thos. Cary \& Son, 1836), 9. 
Boston, formed in 1737. Its purpose was to "cultivate a spirit of unity and harmony among all resident Irishmen and their descendants in the Massachusetts Colony" and to "advance socially and morally the interests of the Irish people." 3 The Society of the Friendly Sons of St Patrick of Philadelphia, established at Burns' Tavern on 17 September 1771, was likewise formed for purely "social and convivial" objects. ${ }^{4}$

As O'Hanly's definition notes, Irish national societies were associations of individuals who shared a common Irish ancestry. They offered spaces within which issues of identity and belonging in both Canada and the British Empire were negotiated, they provided mutual aid for members, as well as social networks of both personal acquaintances and business associates. These functions simultaneously facilitated the integration of migrants into the receiving society and assisted the Irish to re-conceptualize what it meant to be an Irish Catholic by demonstrating their respectability, such as in the temperance movement, as well as their increasing political and voting power. Through these organizations, Irish Catholics sought engagement with the wider society on their own terms.

Though the mutual aid and national aspects of Irish associations were similar across geographical regions, the purpose of the associations themselves differed in particular contexts. For instance, societies in Montreal evolved very differently than they did in other urban centres. They were political from the start and shaped by the contours of local and provincial politics. National societies, starting with the St Patrick's Society, were established by Tory political interests in response to an 1834 St Patrick's Day dinner that had brought pro-reform Irishmen into closer association with French Canadian Patriotes. The Patriotes responded to the establishment of the Tory St Patrick's Society by establishing the St Jean

3 The Constitution and By-laws of the Charitable Irish Society of Boston, (Boston: James F. Cotter \& Co, 1882): 3.

4 A Brief Account of the Society of the Sons of St Patrick; with Biographical Notices of Some of the Members and Extracts from the Minutes, (Philadelphia: Hibernian Society, 1843), 21. 
Baptiste Society. The St Patrick's Society in Montreal was thus a political organization from the start, part of a move to organize Tory politics amongst ethnic communities and mobilize them as loyal and patriotic Britons. These more politicized organizations also celebrated national heritage and relieved poor countrymen. Kevin James notes that the mutual aid provisions helped integrate new arrivals and the patronage of ethnic leaders provided them with valuable social capital and a "springboard to public politics." 5 The traits of sociability and national sentiment outlined by O'Hanly, then, were common across Irish Catholic associational culture.

Continuing to offer fraternal culture, mutual aid, and a sense of belonging, Irish societies would become increasingly sectarian throughout the nineteenth century. Related to this evolution was the Church's increased conservatism. The growing illiberalism of the Catholic Church was heightened by the advent of ultramontanism, a philosophy that placed strong emphasis on the authority of the pope and sought to increase the Church's control over Catholics. It was a school of thought supported by many Irish prelates in Canada, including Bishop Michael Anthony Fleming of St John's, Bishop Ignace Bourget of Montreal, Bishop William Walsh of Halifax, and the Bishop Michael Power of Toronto, among others, as they came to dominate Irish voluntary associations. The increasingly strong position of anti-liberal, ultramontane clerics within Irish Catholic voluntary associations challenged the liberalism that Ian McKay and others argue was emerging and becoming ascendant in Canada at that juncture. ${ }^{6}$

The illiberal position of the Catholic Church was best laid out in the Syllabus Errorum, or the Syllabus of Errors, issued by the Holy See under the direction of Pope Pius

5 Kevin James, "Dynamics of Ethnic Associational Culture in a Nineteenth-Century City: Saint Patrick's Society of Montreal, 1834-56," Canadian Journal of Irish Studies 26, no.1 (2000): 54-55.

6 See, for instance, the articles in Liberalism and Hegemony: Debating the Canadian Liberal Revolution, edited by Jean-François Constant and Michel Ducharme, (Toronto: University of Toronto Press, 2009). 
IX in 1864. The document condemned myriad modern philosophies and schools of thought, including socialism, communism, clerico-liberal societies, and modern liberalism. Eamon Duffy has argued that Pius IX originated as a relatively liberal, modern pontiff and made speeches in which he argued that Catholicism and Liberalism could and should be reconciled. ${ }^{7}$ Yet, Duffy concludes, Pius IX was no liberal. ${ }^{8}$ Moreover, as the Papal States came under threat with the revolutions of 1848, Piux IX became increasingly hostile to liberalism and liberal states. ${ }^{9}$ It was in the Syllabus of Errors that Pius IX detailed his enmity toward the values of nineteenth-century liberalism and outlined his belief that the Roman pontiff cannot, nor should not, reconcile himself to progress, liberalism, and modern civilization. ${ }^{10}$ The Syllabus clearly outlined the Catholic Church's hostility toward liberalism and modernity. Because of ultramontanism, Catholicism was viewed as a faith that could not accommodate itself to pluralism and liberalism.

At the heart of Pius IX's antagonism toward liberalism was the fact that the Church, in the form of the Papal States, was competing for power with the liberal states of Europe. As Jean-Marie Fecteau has argued, the Church and the state were contending to be the locus of authority in the nineteenth century. ${ }^{11}$ E.A. Heaman further argues that the origins of liberalism lay in the power of the churches. A contest for social authority thus occurred between the emergent liberal state and the ultramontane Church. Heaman has argued that though ultramontanes engaged in rights talk, theirs was not a liberal discourse. ${ }^{12}$

Ultramontane leaders were openly hostile to the concept of universal rights, and nineteenth-

7 Eamon Duffy, "The Age of Pio Nono: The Age of Paul Cullen," in Cardinal Paul Cullen and his World, edited by Daire Keogh and Albert McDonnell, (Dublin: Four Courts Press, 2011), 54.

8 Ibid.

9 Ibid., 57.

10 Ibid.

11 Cited in E.A. Heaman, "Rights Talk and the Liberal Order Framework," in Liberalism and Hegemony: Debating the Canadian Liberal Revolution, eds. Jean-François Constant and Michel Ducharme (Toronto: University of Toronto Press, 2009), 164

12 Ibid., 162. 
century Catholic activists talked more about the collective rights of the Catholic Church than the liberties and rights of individuals. ${ }^{13}$ Insistence on the rights and liberties of the Church pervade nineteenth-century ultramontane writings, and Heaman argues that clerics saw no contradiction between denouncing liberalism and defending liberties, so long as they were the liberties of the Church. While it is true that clerical rhetoric emphasized collective rights, Heaman here is placing a positive spin on a self-interested power grab by the Church hierarchy who sought to carve out a distinct social space in which they, rather than the secular state, had sole jurisdiction. This illiberalism, in which the Church was seeking to be seen as the sole authority in the lives of Catholics, became a target for those advancing antiCatholicism in the 1850 s and 1860 s, as well as those liberals who sought to minimize the role of the Church in society.

The Catholic Church dominated Irish Catholic voluntary associations in the nineteenth century and its collectivism and anti-liberalism was in marked contrast to the spirit of volunteerism and liberalism of mainstream associations studied by Darren Ferry. In Ferry's paradigm, the twentieth-century statism that supplanted voluntary associations was foreshadowed by the Protestant movement's shift from moral suasion to legislative regulation. Clerical control, the advent of ultramontanism, and the devotional revolution meant Catholic temperance was shaped by theological arguments more than arguments about state-enforced regulatory frameworks. Deepening anti-Catholicism, which will be explored below in greater detail, meant that Irish Catholic voluntary associations did engage the state on certain issues in order to legitimize their ethnic and religious issues. Militant Irish organizations, like the Hibernian Benevolent Society, emerged to challenge anti-Catholicism and Orange hostility, while the Catholic League and the 1882 Costigan Resolutions

13 Ibid., 163. 
(Chapters Seven and Eight in this study) were examples of using the growing state apparatus to achieve ethno-religious objectives. Irish Catholics argued that their community and their perspective had to be recognized as being part of the pluralism and universalism inherent in the liberal order. Pointing out the exclusionary aspects of the liberal order challenged the dominant mentality in Canada and forced Canadian liberals to accept pluralism to a greater extent that they wanted. Perhaps somewhat ironically, clerical and lay activities that engaged with the state in fact demonstrate Irish Catholic aspirations that their community would have jurisdiction over spheres in which they wanted minimal state involvement. And yet, as later chapters will demonstrate, the Irish Catholic voluntary movement promoted liberal values and engaged in debates in the broader public sphere.

\section{The Rise and Impact of Ultramontanism}

A key component of early Irish voluntary associations was cross-religious membership, as these organizations were open to both Protestant and Catholic Irish. Early associations were made up of elites in urban societies on the brink of transforming from colonial outposts to emerging commercial hubs, including military officers, religious authorities, and mercantile leaders. These societies were charitable enterprises, formed to aid poor and destitute Irish immigrants and their descendants. An example of this type of voluntary association was Halifax's Charitable Irish Society. ${ }^{14}$ Organized in 1786 at a "meeting of a number of respectable Inhabitants" of Nova Scotia, the CIS consisted of "natives of the Kingdom of Ireland." 15 The meeting was held at the house of John O'Brien, proprietor of the Golden Ball

14 Provincial Archives of Nova Scotia, online exhibit on the Charitable Irish Society. https://novascotia.ca/archives/CIS/. Accessed 16 December 2015. Also see Katherine Crooks, "The Quest for Respectability: The Charitable Irish Society in Victorian Halifax," Canadian Catholic Historical Association, Historical Studies 81 (2015): 174.

15 The Rules and Constitution of the Charitable Irish Society established at Halifax in the Province of Nova Scotia, 1795, Canadian Institute of Historical Microreproductions (CIHM) 67291: 4. 
Tavern, and members signed the constitution and rules of the Society for the purpose of "relieving the wants and misfortunes of their Countrymen." In the constitution of the society, qualification for membership was open. Natives of Ireland, descendants of Irish men or women, persons born in the province of Nova Scotia, and descendants of any present or future member of the Society were all eligible for membership, as well as natives of any other country who were inhabitants of Nova Scotia provided they were not members of any national society. Potential members had to be invited to join by a standing member, and would only become members by consent of a majority of the society in a vote at a meeting. Following membership, individuals had to pay a sum of at least twenty shillings into the treasury. In addition to the charitable aspects of the organization, it was also an Irish national association, as it was stated in the inaugural constitution that the society would annually celebrate the Feast of Saint Patrick in commemoration of their native country. ${ }^{16}$ It was therefore formed in part to celebrate Irish identity, but at this juncture Irish identity included Protestant and Catholic Irish. The first president of the CIS, Richard John Uniacke, was an Anglican born in 1753 in Cork. Uniacke would go on to become Attorney General of Nova Scotia and was a leader in the struggle for Catholic emancipation in Nova Scotia. ${ }^{17}$ Uniacke's elite position in society was reflective of the membership of these early Irish voluntary associations across the globe, and his religious denomination reflective of their ecumenical character. ${ }^{18}$

https://archive.org/details/cihm_67219, accessed 12 June 2014.

16 Ibid.

17 B.C. Cuthbertson, “UNIACKE, RICHARD JOHN (1753-1830).” In Dictionary of Canadian Biography, vol. 6, University of Toronto/Université Laval, 2003-, accessed March 15, 2016,http://www.biographi.ca/en/bio/uniacke_richard_john_1753_1830_6E.ht

18 Similarly, the first president of The Society of the Friendly Sons of St Patrick, organized in New York in 1784, was Daniel McCormick, a Presbyterian. Nathan Glazer and Daniel P. Moynihan, Beyond the Melting Pot: The Negroes, Puerto Ricans, Jews, Italians, and Irish of New York City, (Cambridge: M.I.T. Press and Harvard University Press, 1963), 239. Glazer and Moynihan do not mention McCormick by name, but according to the history of The Society of the Friendly Sons of St Patrick in the City of New York, he was indeed the first president. McCormick was elite, as he was a founding director of the Bank of New York, 
Another example of this type of society was the Benevolent Irish Society, founded in St John's Newfoundland on 17 February 1806. It was formed by a group of Irish elites whose aim was to ameliorate the poor conditions under which many Newfoundlanders, mostly Irish, lived. Settlement in Newfoundland began in earnest in the late eighteenth century, as habitation there shifted from seasonal fishing villages to more permanent settlement. From the beginning, Newfoundland had a large Irish Catholic population, which was largely on the lower end of the socio-economic scale. As in most other British colonies in North America, this would change through the course of the nineteenth century, aided in no small measure by collective organizations such as the BIS. Prominent Irishmen of the city attended this initial meeting, held at the London Tavern. These men included representatives of the military, mercantile, and official establishments. At this exploratory meeting it was decided to form a society consisting of Irishmen or descendants of Irishmen, and it was resolved that "a society, formed on the principles of benevolence and philanthropy, would be the most effectual mode of establishing a permanent relief to the wretched and distressed."19 The need for an organization to facilitate social welfare was acute in Newfoundland at this point, as the colony had no municipal government, simply a seasonal naval governor. ${ }^{20}$ At the meeting in which the rules and constitution were drawn up all the men serving on the committee save one, Henry Shea, were Protestants. The Catholic Church was not completely removed from this organization even at this early stage, however, as the meeting was presided over by James Louis O'Donel, the first Catholic bishop of Newfoundland. In all there were 202 original members of the BIS, made up of the prominent, respectable cross-denominational along with Alexander Hamilton, among others. History of The Society of the Friendly Sons of St Patrick in the City of New York: https://www.friendlysonsnyc.com/index.cfm?fl=history. Accessed 19 January 2016.

19 Rules and Constitution of the Benevolent Irish Society: February 17th 1806 (1807), CIHM 68438, 3. https://archive.org/details/cihm_68438, accessed 12 June 2014.

20 Jerry Bannister, The Rule of the Admirals: Law, Custom, and Naval Government in Newfoundland, 16991832, (Toronto: University of Toronto Press, 2003), 13. 
Irish citizens of St John's.

As the nineteenth century wore on, however, Irish Catholic voluntary associations took on more of a sectarian tone as the Catholic Church increased its influence within the community. Prior to mid-century, as Terrence Murphy outlines, the task of founding Catholic institutions fell to the laity, rather than the clergy, because the Church at this juncture had limited resources. The Church, as it existed at the time, could not keep pace with the influx of Irish Catholic immigrants in the 1830s and 1840s. For instance, Nova Scotia, New Brunswick, and Prince Edward Island were under the jurisdiction of the Bishop of Quebec, while Newfoundland, like the former American colonies, had been placed within the London District. Likewise in Upper Canada, there existed only 170 Catholic settlers in $1806,{ }^{21}$ but as more Catholics, mostly Irish, settled, new dioceses had to be created to accommodate the immigrants, such as Toronto in 1841, Hamilton and London in 1856, and Peterborough in 1874. Clerics were concerned about the power the laity wielded in church affairs and tension occurred between clergy and laity over each's role in the Catholic community well before the arrival of the ultramontanes to Canada. John FitzGerald argues that there was a conflict in St John's between lay Catholic trustees who aimed to hold their influence over church affairs and Bishop Michael Anthony Fleming who sought to consolidate and centralize clerical control over the Church. ${ }^{22}$ Rome supported Fleming and he was therefore able to systemically remove lay trustees from position of influence on school and chapel committees. $^{23}$

In Halifax until 1846 church wardens were the legal proprietors of church property.

21 Archives of Roman Catholic Archdiocese of Toronto, Bishop Macdonell Fonds, M CG01.02, letter from Rev. Alexander Macdonell to Bishop Plessis, 10 May 1806.

22 John E. FitzGerald, "Conflict and Culture in Irish Newfoundland Roman Catholicism, 1829-1850," (PhD Diss., University of Ottawa, 1997), ii.

23 Ibid., iii. 
Before a Catholic parish could be established in the Atlantic colonies, the congregation had to obtain the permission of the government. Once this was achieved, lay leaders purchased land, erected chapels, and recruited priests. In doing so, they became the proprietors of the land. Murphy outlines the tension caused between the clergy and the laity, which was only resolved after the arrival of the ultramontane bishop William Walsh who promoted an 1846 bill that created an episcopal corporation. From that point forward, all church property was vested in the Catholic bishop and his successors. ${ }^{24}$

The episode in Halifax was not an isolated incident, and to better understand the transnational community-building work of Irish clerics it is useful to employ the framework of the Irish spiritual empire. Fiona Bateman, Peter Cunich and others have explored this concept, which is a paradigm meant to indicate that the growth of the Catholic Church in the British Empire was a spiritual realization parallel with and equal to the political and cultural empire established by the British state, but not under its control. ${ }^{25}$ The creation of this spiritual empire occurred through the settling of Irish-born and Irish-trained priests and bishops across the British Empire. Cunich explored this spiritual empire in Australia in the late nineteenth century through the work of Roger Vaughan, who was the Archbishop of Sydney between 1877 and 1883. Cunich concluded that rather than attempting to create an Irish-centric spiritual empire, the development of the Catholic Church in Australia must be considered as a part of the imperial goals of Rome and the Holy See. ${ }^{26}$

A rather different perspective on the Irish spiritual empire was presented by Colin

24 Murphy, "Trusteeism," 143-44.

25 Peter Cunich, "Archbishop Vaughan and the Empires of Religion in Colonial New South Wales," in Empires of Religion ed. Hilary Carey (London: Palgrave Macmillan, 2008), 137; Fiona Bateman, "Ireland's Spiritual Empire: Territory and Landscape in Irish Catholic Missionary Discourse," in Empires of Religion ed. Hilary Carey, 267; Tadhag O hAnnrachain, "The Consolidation of Irish Catholicism Within a Hostile Imperial Framework: A Comparative Study of Early Modern Ireland and Hungary," in Empires of Religion, ed. Hilary Carey, 25.

26 Cunich, "Archbishop Vaughan and the Empires of Religion,” 154. 
Barr, who argues that starting in 1839 a concerted effort began to get Irish clergy appointed to sees throughout the British Empire and the United States by employing ruthless campaigns of disinformation to unseat non-Irish incumbent bishops. The effort was spearheaded by Paul Cullen, later archbishop of Dublin, who at this juncture was rector of the Irish College in Rome. ${ }^{27}$ Cullen, Barr argues, made Irish ethnicity and ultramontanism the key points in his push to populate the global Catholic Church with Irish clergy. Cullen was able to wield such power because of his influential position in the Sacred Congregation for the Propagation of the Faith - the Propaganda — and because it was the Propaganda that supervised the Church in the United States, British Isles, and the British Empire. ${ }^{28}$ Cullen entered the Propaganda in 1819 and remained there until he was appointed rector of the Irish College in Rome in 1831. He continued to wield influence within the Propaganda even after his departure owing to the relationships he built up with successive cardinal prefects there, the most important of whom was Alessandro Barnabo, who was secretary to the Propaganda from 1848 to 1856 , and then prefect till his death in $1874 .{ }^{29}$ Cullen's project originated as a response to anti-Irish feelings within the Church, and the feeling, after the second provincial council of Baltimore in 1833, that the Irish were being shut out by American and French leaders in the American Catholic Church. Irish-born prelates John England and Francis Patrick Kenrick, who were stationed in the United States, turned to Cullen as their man in Rome. Barr outlines the pattern which repeated itself, with the Irish coming to dominate Catholic jurisdictions across the English-speaking world:

First, Irish-born priests began to make loud complaints about their non-Irish bishop,

27 Mark McGowan, Michael Power: The Struggle to Build the Catholic Church on the Canadian Frontier (Montreal and Kingston, McGill-Queen's University Press, 2005.), 107.

28 Colin Barr, "Imperium in Imperio": Irish Episcopal Imperialism in the Nineteenth Century," English Historical Review, CXXIII, 502 (June 2008): 614.

29 Barr also comments on Cullen's skills as a translator in securing and maintaining his influence in the Propaganda. Barr, "Imperium in Imperio," 615. 
either to an isolated Irish bishop in the same hierarchy or directly to Rome; the complaints - however unlikely — were taken seriously at the Propaganda, which began to turn on the existing (non-Irish) hierarchy. Over time the Propaganda enabled an Irish take-over of the episcopate in three distinct ways: appointing a coadjutor with right of succession to the most important see or the most important non-Irish bishop; creating new dioceses and appointing Irishmen to head them; filling vacancies of existing dioceses with Irish candidates. Once a majority was achieved, regular national synods imposed the policies of the majority on any remaining minority. Even when the strategy failed, the pattern was clear. ${ }^{30}$

In his study of William Walsh's appointment as Bishop of Halifax in the 1840s, Terrance Murphy demonstrates that this pattern was evident in British North America. Murphy notes that significant tension existed between the Scottish Vicar Apostolic of Nova Scotia William Fraser, his Vicar General John Loughnan and the largely Irish congregation of Halifax. The Irish in Halifax successfully lobbied to get Walsh appointed as coadjutor without Fraser's knowledge. Murphy notes that Cullen in Rome proposed the appointment of a coadjutor to Fraser. Walsh was connected to Cullen through Tobias Kirby, Vice-Rector of the Irish College in Rome. Cullen used his position and influence in Rome to advocate for Walsh, who was eventually appointed coadjutor and arrived in Halifax in 1842. This upset Fraser, who was not consulted about the decision and resulted in an escalation of the sometimes bitter rivalry between the two factions. ${ }^{31}$ Walsh's appointment as coadjutor against the wishes of Bishop Fraser indicates a struggle between the Scottish population in northern Nova Scotia, where the diocese of Nova Scotia was centered, and the Irish of Halifax, who controlled the parish there and wanted to have Irish clergy who would support their aspirations and get out from under Scottish control. The Irish in Halifax agreed to go along with Walsh's ultramontanism so long as Walsh stood up for Irish interests, which he did in various ways such as reorganizing the temperance society under the control of Irish

30 Ibid, 620.

31 Terrance Murphy, "Transformation and Triumphialism: The Irish Catholics of Halifax, 1839-1858," Unpublished paper delivered at CCHA Conference 2014. 
clergy $^{32}$ and founding a second parish made up of a largely Irish congregation. The diocese was then divided, with the Irish controlling the new one and Fraser controlling a much smaller, and more Scottish, territory than before. Thus, Walsh in Halifax fused Irish and papal interests and ensured their rise by working to increase papal authority. The work of Barr and Murphy throws cold water on Cunich's notion that there existed a dualism between an Irish spiritual empire and a Roman one. According to these authors, there existed a mutually supportive relationship between the two, what Barr refers to as a "Hiberno-Roman fusion of devotional and administrative practice."${ }^{.33}$

The Irish spiritual empire as it functioned in practice reflected dominant trends within the Irish Catholic Church in the mid-nineteenth century. While the first was the advent of ultramontanism, another major trend in Irish Catholicism at this juncture was what Emmet Larkin termed "the devotional revolution," which was tied to ultramontanism but focused more narrowly on the Irish community. Larkin pointed out that prior to the Great Famine of 1845-49, the Irish, though nominally Catholic, were not practising the rituals of the Church to the extent the Church deemed appropriate. Adherence to such practices increased throughout the 1840s and 1850s as a centralizing hierarchy set new standards of religious observance and behaviour. ${ }^{34}$

The Irish spiritual empire also encompassed an administrative revolution that saw the rebuilding of religious infrastructure shattered by the Protestant Reformation and the anticlericalism of Revolutionary and Napoleonic Europe. One of the strategies of ultramontanist

32 The reorganization of the temperance society will be explored in greater detail in the following chapter.

33 Barr, "Imperium in Imperio," 612.

34 Emmet Larkin, “The Devotional Revolution in Ireland, 1850-1875," American Historical Review 77, no. 3 (June 1972): 625. Larkin's thesis has elicited, and continues to elicit, considerable scholarly debate. See Thomas G. McGrath, "The Tridentine Evolution of Modern Irish Catholicism, 1563-1962: A Reexamination of the 'Devotional Revolution' Thesis," Recusant History, 20, no. 4, (October 1991): 512; And all of the essays in Stuart J. Brown and David W. Miller, eds, Piety and Power in Ireland, 1760-1960:

Essays in Honour of Emmet Larkin, (Belfast: Institute of Irish Studies and University of Notre Dame Press, 2000). 
clerics was to import European religious orders to Canada to strengthen church infrastructure. Murray Nicholson notes that in Toronto, Bishop Armand de Charbonnel brought over religious orders who promoted devotional, moral, and social renewal. ${ }^{35}$ Bishop Michael Anthony Fleming established two communities of Irish religious orders in St John's, the Presentation Sisters in 1833 and the Mercy Sisters in $1842 .{ }^{36}$ Bishop Remi Gaulin of Kingston, with the help of the Bishop of Montreal, Ignace Bourget, brought the Sisters of the Congregation of Notre Dame to Kingston in $1841 .{ }^{37}$ In 1868, Bishop John Walsh of London invited the Sisters of St Joseph to the diocese under his care. ${ }^{38}$

Parish associations were also established to create a Catholic subculture under hierarchical control. In his study of the Irish Catholic community in mid-nineteenth-century Toronto, Brian Clarke has argued that the clergy introduced voluntary organizations that emphasized secular pastimes in order to establish an associational environment that would prove more amenable to Irish Catholic men and facilitate their incorporation into Catholic culture. In Clarke's estimation, a central purpose of Irish Catholic temperance societies was to co-opt otherwise non-practising lay members of the parish into participation in cultural activities within a Catholic world. ${ }^{39}$ Irish Catholic confraternities fit the outline of ultramontanism, the devotional revolution, and the spiritual empire and must therefore be understood within the framework of clerically-led Irish Catholic community building that was so prevalent among the global Irish Catholic diaspora in the nineteenth century.

35 Murray W. Nicholson, "Bishop Charbonnel: The Beggar Bishop and the Origins of Catholic Social Action," CCHA Historical Studies, 52 (1985), 51.

36 Carolyn Lambert, "Far from the Homes of their Fathers: Irish Catholics in St John's, Newfoundland, 184086," (PhD Diss., Memorial University, 2010), 74;

37 Calista Begnal, "Sisters of the Congregation of Notre Dame Nineteenth Century Kingston," CCHA Study Sessions, 40 (1973), 27.

38 Julia Moore, "The Sisters of St Joseph: Beginnings in London Diocese, 1868-1878," CCHA Study Sessions, 45 (1978): 43. Moore also notes that the Sisters had come to Toronto in 1851, and Hamilton in 1852.

39 Brian Clarke, Piety and Nationalism: Lay Voluntary Associations and the Creation of an Irish-Catholic Community in Toronto, 1850-1895 (Montreal and Kingston: McGill-Queen's University Press, 1993), 127. 
In 1878 John Joseph Lynch, Archbishop of Toronto, observed that Irish societies under the direction of the clergy formed "banks to preserve this mighty flood of population from being washed and absorbed in other and less religious people." ${ }^{40}$ This indicates Lynch's view that voluntary associations ought to be formed and operated upon a Catholic basis, to prevent Catholics from losing their faith and obedience to the clergy while living in a largely non-Catholic environment. An example of an ultramontane cleric who privileged papal over state authority, aimed to spread Catholic culture, and was involved in Irish Catholic associational life was Rev. George Richard Northgraves. Though not of Irish heritage, by appealing to Irish ethnicity and expressing ultramontane views, Northgraves was able to earn the support of Irish parishioners and cement adherence to ultramontanism within the Irish Catholic temperance movement. As a Catholic cleric at the centre of Irish Catholic associational life, with its religious and civic aspects and political divisions, Northgraves was a representative figure. However, what was less common about Northgraves' activities as president of the Father Mathew Society, prominent place at St. Patrick's Day festivities, and role within the heated Irish Catholic cultural world of the 1860s, was his non-Irish heritage. Northgraves was born in 1834 in what was then known as Bytown. His father, William Northgraves, was a jeweller. In the 1919 obituary of Northgraves published in the London Catholic Record it was noted that Northgraves' old English Catholic family was "one of that glorious remnant who, despite persecution and penal laws, never lost the faith." ${ }^{41}$ Northgraves' mother, Therese Prussien dit Nicole, was a French Canadian Catholic from Quebec. Thus, Northgraves had a long history of Catholic heritage, but he himself was not Irish. He had, in fact, no Irish roots whatsoever. This points to the dualism of the Roman and Irish Empires that were intermingled in the development of an Irish Catholic community

40 ARCAT, Archbishop Lynch Fonds, LA A11.24, Pastoral Letter on the Festival of St Patrick, 1878.

41 London Catholic Record (London), 3 May 1919, p. 5, cols. 5-6. 
in Canada.

He was educated at Catholic private schools in Kingston and Belleville, and at the age of eighteen became a pupil at St. Michael's College in Toronto. Northgraves was one of the first students at that institution, beginning his studies only two weeks after it was opened in St. Michael's Palace. Clearly a gifted student, in 1854 Northgraves became a professor at the College where he would teach Rhetoric and Belles Lettres. ${ }^{42}$ During his time as professor, he continued his studies for the priesthood and was summoned in August of 1857 by Bishop John O' Farrell of Hamilton. He continued his professorship until 1860, when he became rector of St. Michael's Cathedral.

Northgraves was president of the Toronto-based Father Mathew Total Abstinence and Literary Society in Toronto in the $1860 \mathrm{~s} .{ }^{43}$ The Father Mathew Society worked in conjunction with other Irish Catholic societies of Toronto, such as the Hibernian Benevolent Society. He was held in high esteem by leader of the HBS, and editor of the Irish Canadian, Patrick Boyle, who referred to Northgraves as a "polished gentleman, a scholar of the highest mental culture, an eloquent and zealous Priest, and a man the generosity of whose heart is equaled only by his humble and unobtrusive disposition." 44 Northgraves and the Father Mathew Total Abstinence and Benefit Society held pride of place at the 1863 St. Patrick's Day celebrations in Toronto, which were organized by the HBS. Members of the grand procession were addressed by Lynch, president of the Hibernian Benevolent Society Michael Murphy, and Northgraves, among others. During his speech, Northgraves praised his mostly Irish audience for the "nobleness of the display" they made upon this occasion, and "held up Ireland's patron saint as an example" to follow. ${ }^{45}$ Northgraves concluded by

42 The Metropolitan Catholic Almanac and Laity's Directory (Baltimore: John Murphy \& Co., 1860), 284.

43 Irish Canadian (Toronto), 7 January 1863, p. 5, col. 4.

44 Irish Canadian (Toronto), 11 February 1874, p. 4, col. 3.

45 Irish Canadian (Toronto), 18 March 1863, p. 4, col. 5 continued on p.5, cols. 1-2. 
lauding their behaviour that day, saying that "the manner in which they had celebrated the occasion reflected great credit to the society of which he had the honor to belong., ${ }^{46}$ Northgraves' speech thus rhetorically linked temperance with tropes of Irish Catholic identity such as St Patrick and praised the respectability of the celebrants that derived from their membership in an organization under clerical leadership.

Northgraves was thus no stranger to Irish Catholic associational life, nor was he ignorant of the divisions among the Irish Catholic community. His presence on stage with Lynch and Murphy suggests an attempt to put a public face on unity. As we will see in subsequent chapters, Murphy was at the centre of the Fenian controversy in Canada in 1866, even being arrested and held in prison for suspected Fenian activities. In his role as Archbishop, Lynch was careful not to alienate those with more radical political leanings, such as Murphy, while at the same time he did not want to alienate political allies who opposed the physical force nationalism of the Fenians.

Northgraves' career is a testament to his activities spreading Catholicism in conjunction with Irish national sentiment. He would proudly recount how his work in aiding the separate school cause thwarted "the designs of the Orange Party," 47 but this had wider implications as well This incident in question began when Northgraves got wind of a meeting scheduled by Orangemen to discuss the matter of Catholic schools in Canada West. The purpose of the meeting was to pass a resolution opposing these schools, and then present this resolution to the government as evidence of a lack of support for the creation of a system of tax-supported Catholic separate schools. Upon hearing this, Northgraves notified the Catholics in the area of the meeting and urged that they be there at least one hour ahead of the designated starting time. In consequence, the hall was full of Catholics with little

46 Ibid.

47 Ibid. 
room left for others to enter. What was described as "a somewhat lively meeting" began and, much to the consternation of the officers who had organized the gathering, a resolution in favour of Catholic schools was passed. ${ }^{48}$ It was said by Northgraves' memorialists that the government of day cited this resolution as the reason for the speedy passage of the Separate School Bill. ${ }^{49}$ The extent to which Northgraves and his plan were responsible for the passage of the bill is less important than what this event represents: Northgraves as a champion for a Catholic cause aimed at maintaining clerical control over the education of Catholics, an important element in the creation of a Catholic cultural world.

Northgraves would choose Catholicism over other worldly pursuits. He turned down the position of Chair of Mathematics at Toronto University to remain in the priesthood. He would become Dean of Barrie north of Toronto in the 1860s, until he was moved to Rome where he attended the Vatican Council as theologian of Archbishop Lynch. Upon his return from Rome, Northgraves was appointed Archdeacon of St. Michael's Cathedral. ${ }^{50}$ Then, he was requested by his old classmate Bishop John Walsh of London to take up a position in the Diocese of London as Rector of St. Peter's Cathedral. ${ }^{51}$ Upon his departure for London, the priests of the Archdiocese of Toronto marked their esteem for Northgraves by presenting him with an address and a purse of $\$ 175 . .^{52}$

Upon his arrival in the Diocese of London, Northgraves took up the battle against the forces of secularism and rationalism by attacking well-known atheist Robert Ingersoll in a book lengthily entitled The Mistake of Modern Infidels, or, Evidences of Christianity:

48 Ibid.

49 London Catholic Record (London), 3 May 1919, p. 5, cols. 5-6. Though this assertion should not be taken at face value, as the Northgraves memorialists likely exaggerated his contribution to the schools question.

50 Irish Canadian (Toronto), 18 March 1863, p. 4, col. 5 continued on p.5, cols. 1-2.

51 Irish Canadian (Toronto), 11 February 1874, p. 4, col. 3.

52 Ibid; Rev. William Cochrane, The Canadian Album. Men of Canada; or Success by Example in Religion, Patriotism, Business, Law, Medicine, Education and Agriculture, (Bradley, Garreston \& Co.: Brantford, Ontario, 1891), 419. 
Comprising a complete refutation of Colonel Ingersoll's so-called Mistakes of Moses, and objections of Voltaire, Paine, and others against Christianity. ${ }^{53}$ Ingersoll was an American public lecturer who advocated secularism and humanism, and poked fun at religious belief and pretensions. Northgraves dedicated this Catholic polemic to Bishop John Walsh of London calling his text a testimony of the high-esteem, affection, and veneration that Northgraves had for Walsh. In reply to this dedication, Walsh noted that he was "glad to know that you have prepared a work in reply to Ingersoll's 'Mistakes of Moses' and that it is now ready for publication. ${ }^{54}$ In evaluating the importance of this work to counter what he termed "the infidel cause" Walsh proclaimed:

In view of the momentous issues involved in the questions raised by the infidel school, in view of the nearest and dearest interests of individual man and of society attacked and imperilled by the agents of unbelief - a work like yours which exposes the sophisms of the aforesaid school, which confutes its errors, which thoroughly refutes and pulverizes its objections and which triumphantly defends the outworks and the fortress of Christian truth and belief — such a work, I say, is eminently deserving of the favorable recognition and patronage of the public and is sure to receive hearty encouragement and warm welcome from all who love "the faith once delivered to the saints. ${ }^{.55}$

Thus Northgraves was first and foremost a Catholic ultramontane. He assumed clerical leadership over the Father Mathew Total Abstinence and Literary Society, and though not of Irish origin himself he happily tailored his rhetoric to accord with Irish Catholic tropes and the sensibilities of its Irish membership, and he took pride of place at Irish ethnic festivals. But in combating Orange influence in defence of separate schools he also challenged the liberal state's right to educate Catholic children, and his polemic against the atheist Ingersoll

53 George Northgraves, The Mistake of Modern Infidels, or, Evidences of Christianity: Comprising a complete refutation of Colonel Ingersoll's so-called Mistakes of Moses, and objections of Voltaire, Paine, and others against Christianity, (Detroit: Free House Printing Press, 1885), 13.

54 Ibid., 5.

55 Ibid., 8. 
was a defence of Catholic theology against the growing rationalism and secularism of the liberal order. At this juncture, Pius IX was the locus of authority amongst Catholics, and Northgraves was one of the clergy who enacted his pronouncements in the daily lives of colonial Catholics.

The hierarchy condemned Irish voluntary associations not under clerical direction and supported lay-organized Irish Catholic societies only insofar as those societies fell under the control of the Catholic Church. As the Catholic Church gained a more prominent place in Irish voluntary associations, existing societies that had been constituted under ecumenical principles were reorganized under clerical control. Kevin James has outlined how the Montreal St Patrick's Society was reorganized in 1856 to allow for greater control by the Catholic Church. ${ }^{56}$ Increasing political factionalism amongst the Irish developed with a growing Catholic population and an ultramontane clergy, but they were also divided over Francis Hincks's presidency. In 1850, ultramontane Irish cleric Patrick Dowd arrived to take charge of the new St Patrick's Church and established a host of confessional associations. Under Dowd's influence, and with a majority Catholic membership, the St Patrick's Society voted to confessionalize in 1856 , which prompted the Protestant members to establish their own benevolent organization. A similar reorganization seems to have occurred in Hamilton as a major change in the religious makeup of leadership in the Hamilton St Patrick's Society occurred in the 1860s. Henry McKinstry, the mayor of Hamilton who was a member of the Church of England and had been born in Antrim, Ireland, chaired the inaugural meeting of the St Patrick's Society in 1860, and in 1862-3 McKinstry was listed as president. In 1862-3, the second vice-president of the society, Thomas Gray, was also a Protestant, as was the organization's secretary and treasurer, William Irwin. ${ }^{57}$ After significant reorganization, 56 James, "Dynamics of Ethnic Associational Culture," 47.

57 True Witness and Catholic Chronicle (Montreal), 22 June 1860, p. 5, col. 4; Hutchinson's Hamilton City 
however, Hamilton's St Patrick's Society was transformed into a Catholic body by the end of the 1860s. The clergy of St Mary's Cathedral were listed as chaplains of the society and the secular leadership was also Catholic. ${ }^{58}$ This was likely the result of the creation of the Diocese of Hamilton, established by papal decree on 29 February 1856. The first bishop of Hamilton was John Farrell. Farrell, born in Armagh in 1820, emigrated to Canada with his entire family and settled in Kingston in 1832. Upon his consecration as bishop, Farrell built a new cathedral, St Mary's, after a fire destroyed the old wooden church. Farrell was also an active participant in the Irish Catholic voluntary movement, and sought to employ organizations like the St Patrick's Society to counter the rising popularity of revolutionary Irish societies such as the Fenian Brotherhood and the Hibernian Benevolent Society. ${ }^{59}$ In the Maritimes, the non-denominational origins of the CIS and the BIS likewise changed as they grew closer to the Catholic Church. In Halifax, Katherine Crooks argued, by mid-century the Charitable Irish Society had transformed from a society led by Anglo-Irish aristocrats such as Uniacke to one that was more "Catholic in character." 60 The process of "Catholicization" 61 also took place in the Benevolent Irish Society of St John's. In the 1840s the patron of the BIS had been the governor of Newfoundland, but owing to its increasingly Catholic make-up, the society resolved to appoint the Catholic bishop of St. John's as copatron. ${ }^{62}$ The Church and its many Irish-born clerics used ethno-religious confraternities, church-run societies, and their increasing influence within the Irish Catholic culture to achieve a position of community leadership. Part of the reorganization of the BIS as a

Directory, 1862-3, (Hamilton: Eastwood, 1862).

58 Hutchinson's Hamilton City Directory, 1869, (Hamilton: 1869).

59 Arthur P. Monahan, "Bishop Farrell of Hamilton as a Participant in the Political Life of his Day", Canadian Catholic Historical Association, Report 27 (1960): 26.

60 Crooks, “The Quest for Respectability," 176.

61 Ibid.

62 Provincial Archives of Newfoundland and Labrador, MG612 28303, Benevolent Irish Society Minute Book, 28 July 1850. 
Catholic institution centred on the efforts of the Tipperary-born Bishop of Newfoundland, Michael Anthony Fleming. Fleming was Bishop from 1830 until his death in 1850, and espoused an ultramontane ideology. ${ }^{63}$ Carolyn Lambert argues that under Fleming's leadership in the 1830 s and 1840 s, there "emerged an institutionalized and reinvigorated Catholic Church" that was shaped by his ultramontane views. ${ }^{64}$ Fleming expanded church infrastructure and recruited Irish-born clergy. ${ }^{65}$ Fleming was thus part of a global movement in which Irish priests were sent to communities across the English-speaking Catholic world. This would result in Catholic voluntary associations transforming from ecumenical, crossreligious organizations to ones in which the clergy exercised considerable control, and adherence to Catholicism became a qualification for membership, even among the executive committees.

Fleming had a combative relationship with the leadership of the BIS, and the lay community in general. In the 1820s, when he was not the bishop of St John's but instead working under Bishop Thomas Scallan, Fleming and the BIS clashed over the operation of the BIS-run Orphan Asylum School. The school, like the BIS at this juncture, was nondenominational and so religious books were excluded from the curriculum. However, since most of the students, and all of the teachers were Catholic, Fleming insisted that Catholic theology be taught. So incensed was Fleming, that he secretly taught the students theology, and prepared them for their first communion. The BIS appealed to Scallan to prevent Fleming from holding a public procession for the students. Scallan assented and Fleming held a private ceremony with the students. Fleming would enjoy more power after he became bishop of St John's in 1830, and his rivalry with the BIS would continue until his

63 Carolyn Lambert, "Far From the Homes of Their Fathers," 74.

64 Ibid.

65 Ibid. 
death in 1850 .

Fleming clashed again with the BIS over the school in 1849 . When the Society allowed an individual by the name of Mooney to lecture in the school rooms, Bishop Fleming ordered the Christian Brothers in charge of the school to close the building. A meeting was held by the BIS to discuss the matter, where a resolution proposed that the Society alone had the power to grant the use of the rooms for any purpose whatsoever, a clear rebuke of Fleming's interference. The resolution divided the voting members of the BIS, and the resolution failed to pass, as 25 members voted for and 26 against. In response, the president of the Society, John Nugent, resigned his post. ${ }^{66}$ Nugent's resignation was seen as a further slight to the Bishop. Fleming wrote to the BIS stating that he had been "slandered" by the Society simply for expressing his disapproval of the permission given to Mooney, whom Fleming referred to as "a very doubtful character," to "desecrate your asylum, a place devoted to religion and scandalize the faithful with his indecent songs." Because of the BIS's actions in this regard, Fleming asked that his name be withdrawn as Vice Patron of the Society, asserting that "no consideration can induce me to hold the office a moment longer. ${ }^{968}$ In response, the BIS sent their thanks to Fleming for his support and contributions over the past 25 years and expressed "deep unqualified and sincere regret that Fleming had resigned the Vice Patronship of the Society." ${ }^{69}$ Nugent forwarded the Society's expression of regret to Fleming, along with a preface in which he insisted that his resignation was "not in the remote degree actuated by the slightest intention of exhibiting toward your Lordship, either spiritually or otherwise, the slightest offence," and pleaded with Fleming to

\footnotetext{
PANL, Benevolent Irish Society Minute Book, 1844-59, MG612, 10 October 1849.

Ibid., 18 February 1850.

68 Ibid.

69 Ibid.
} 
pardon his actions. ${ }^{70}$ Fleming felt gratified by these apologies and expressions of respect, and though he did not stay on as Vice Patron, citing his poor health, he did remain a member of the Society, asserting that he looked forward to continuing to contribute his "humble services in the discharge of any duty regarding me as a members of the BIS." ${ }^{\prime 71}$ Fleming died shortly thereafter, on 14 July 1850, and the BIS participated in the funeral procession. In the BIS annual officer's report for 1850, it was noted that during the whole period of Fleming's residency in St John's he was "bound up with the Society in the bonds of affection.""72 Well, perhaps not quite "the whole period." The fact that the Society backed down in the face of episcopal pressure indicates the powerful role of Catholic clerics such as Fleming in the formerly ecumenical BIS, and is representative of the increased influence of the Catholic hierarchy in Irish voluntary associations amidst the growing sectarianism in Canada during the $1850 \mathrm{~s}$.

Another example of clergy-lay conflict centered around the actions of the Irish Catholic Union, an organization that was active in Montreal in the 1870s. The ICU was formed in opposition to the Orange Order. ${ }^{73}$ Much like the HBS in Toronto, the formation of the ICU was framed by its organizers as a necessity owing to Protestant hostility and to defend visible religious identity in Montreal. ${ }^{74}$ The ICU was opposed by Catholic clergymen Patrick Dowd and Michael Hogan. The basis for this opposition lay in the local Montreal branch of the society falling under the control of a general leadership not connected with the Montreal Archdiocese. Dowd and Hogan critiqued the Irish Catholic Union's nine-person Supreme Council, which alone had authority in all matters that concerned the entire union,

70 Ibid., 24 February 1850.

71 Ibid.

72 Ibid., 17 February 1851

73 Raymond Jess, "Re-centering the Periphery: The Protestant Irish of Montreal and the Birth of Canadian National Identity," (MA Thesis, Concordia University, 2013), 48; Montreal Daily Star, 12 March 1877, p. 2.

74 Jess, "Re-centering the Periphery," 48. 
and whose judgments were final. They were concerned that the Supreme Council of the Irish Catholic Union "may cast aside the rightful authority of the Bishop and the pastor of Montreal over their flock."75 They further asserted that the Supreme Council assumes "authority incompatible with the just authority of the Church," and warned that "any body of Catholics resolving themselves into a position inviting a very probable antagonism with their ecclesiastical guides expose themselves to a grave danger and imperil the existence of their society." 76 Dowd and Hogan felt threatened by the possibility of an Irish society operating outside their control.

For clerical leaders like Walsh, Fleming, Dowd, and Hogan, then, Irish Catholic voluntary societies were tools to carve out Catholic cultural spaces distinct from mainstream Protestant culture and operated as a means to position the Church as the pivot around which the Irish community functioned. These clerics jealously guarded their position of community leadership from lay-directed associations.

\section{$\underline{\text { Anti-Catholicism and Community Responses }}$}

Through voluntary associations and confraternities, ultramontane Catholic clergy established themselves as leaders in the Irish Catholic community and drew strict boundaries between Irish Catholics and the rest of the population. For working-class members or middle-class leadership however, joining Irish voluntary associations centered on adjusting to settlement and adapting to life in Canada. That these societies tended to be directed or at least approved by the Catholic Church was a positive feature of associational life as it meant settlement and adaptation in Canada could be accomplished through an institution they were familiar with,

75 Archives of the Archdiocese of Montreal (ACAM), 355.121, Paroisse St Patrick, n.d., "Irish Catholic Union," Dowd and Hogan give their Opinion on Irish Catholic Union of Montreal to Fabre.

76 ACAM, 355.121, Paroisse St Patrick, n.d., "Irish Catholic Union," Remarks on Irish Catholic Union. 
working with clergy who shared their religion and in many cases their Irish nationality. Certainly there were instances when the working-class or middle-class leadership of Irish Catholic voluntary societies clashed with the Catholic hierarchy, as evidenced by the organizational structure of the Irish Catholic Union that so angered Dowd and Hogan. However, belonging to an association that was either clerically-led or clerically-authorized carried much weight within the Irish Catholic community, bestowing prestige and enhancing respectability. ${ }^{77}$ The process of constructing and enforcing Irish Catholic ethno-religious consciousness went hand in hand with growing anti-Irish and anti-Catholic sentiment in much of Canada, as the mainstream Protestant population, too, sought to separate itself from Irish Catholics. Anti-Catholicism was one stimulus to the organization of new Irish Catholic associations that were more radical, and aimed at responding to Orange aggression.

J.R. Miller has advanced a careful analysis of the tenets of anti-Catholic thought in mid-nineteenth-century Canada. The Protestant critique of Catholicism, argued Miller, centered around the authority of the pope in Catholic teaching, rather than the authority of scripture as in most Protestant denominations. For Catholics, scripture was interpreted by humans whom the Church invested with authority. And for Protestants this was one of the misguided teachings of Catholics. Others included transubstantiation, idolatry, confession, and priestly absolution. Miller argued that it was not much of a leap to move from these theological failing to moral failings: "the nineteenth-century critique that originated in theological differences evolved ineluctably into a social, economic, and political attack on the place and role of Catholicism in Canada." 78 Another major aspect of anti-Catholic

\footnotetext{
77 Anthony Layng, "Voluntary Associations and Black Ethnic Identity," Phylon, 39, no. 2 (1978): 176. Layng argues that black leaders and activists in the American civil rights movement achieved community prestige through their participation in voluntary associations, and concludes that such prestige was a significant factor in explaining the importance of voluntary associations within the African American population.

78 J.R. Miller, "Anti-Catholicism in Canada from the British Conquest to the Great War," in Creed and Culture: The Place of English-Speaking Catholics in Canadian Society, 1750-1930, ed. Terrence Murphy
} 
thought was the fact that within ultramontanism, the pope claimed jurisdiction in areas superior to that of the state. In this sense, Catholicism was inherently illiberal, could not be reconciled with the liberal order, and constituted a serious challenge to state authority.

John McCormick, a fire and life insurance agent who had an office on Spadina Avenue in Toronto, was a frequent letter-writer to the Irish Canadian. In one letter McCormick explored the ways in which the moral failings of Irish Catholics, as theorized in anti-Catholic thought, were disseminated to a global audience. ${ }^{79}$ McCormick outlined the history of anti-Irish and anti-Catholic prejudice through a look at language and representation. McCormick argued that in the press, Anglo-Saxons have "taken pleasure in writing down the Irish people" and held them up before the world "only deserving the world's scorn, contumely, and contempt." 80 The Irish had been painted by the English press as "Wild Irish," "Savage Irish," "Lazy Irish," "Drunken Irish,” Priest-ridden Irish," "Ignorant Irish," "Blood-thirsty Irish," "Murderous Irish," and "Low Beggarly Irish."81 McCormick opined that because such representations of the Irish have been carried all over the world through the English press, they have had a pervasive detrimental effect. ${ }^{82}$ The prescient post-modern view of McCormick on the use of language and representation to "other" the Irish worked in conjunction with material events to shape and transmit antiCatholicism and anti-Irishness across the globe.

Despite reformulations in the history of the Irish, the popular impression of Irish immigrants remains the starving famine migrant. Considering the extent of suffering and the impact that this catastrophe had on Ireland and countries such as Canada and the United

\footnotetext{
and Gerald Stortz (Montreal and Kingston: McGill-Queen's University Press, 1993), 35.

79 Irish Canadian (Toronto), 16 August 1871, p. 5, col. 4.
}

${ }^{8}$ Ibid.

81 Ibid.

82 Ibid. 
States who received them, this is not surprising. Mark McGowan has argued that the horrifying events of the Famine, particularly Black '47, "left an indelible impression on both the host society and the Irish Canadian settlers." ${ }^{83}$ Kevin James and Jason King likewise argue that the Famine migration had such a lasting effect on society that it continues to shape how the Irish immigrant experience is viewed in Canada. ${ }^{84}$

While images of Irish famine migrants hastened antagonism toward the Catholic population, other factors deepened anti-Catholic feelings in the 1850s. Pope Pius IX had become a conservative reactionary in response to the 1848 revolutions in Europe that had attacked his jurisdiction in the Papal States, and the Church was consolidating and extending its infrastructure globally. The power of the pope within ultramontane teachings meant that many in the wider society felt that Catholicism was a faith that could not be reconciled with modernity and liberalism. New laws in favour of Separate Schools in the early 1850s further hardened anti-Catholic feelings.

The illiberalism of the Church and the connection between Catholicism and despotism was typical of anti-Catholic thought, which presented Catholics as slavish followers of corrupt and immoral priests, not as worshippers of a faith. Catholicism, in this view, was inherently illiberal and inconsistent with the values of liberal society. Because Catholics followed the pope, rather than the state, they were deemed unfit for citizenship. This theme was furthered in a 9 July 1856 article in which the Globe criticized the political activities of the Catholic Bishop of Toronto, Armand de Charbonnel:

The conduct of the Bishop to those who have been the political leaders of his people is eminently characteristic of the Church to which he belongs...He draws up a paper in which he informs the faithful that certain members of Parliament are unworthy of their support at the polls and indicates that of they do not med

83 Mark McGowan, Creating Canadian Historical Memory: The Case of the Famine Migration of 1847, Canada's Ethnic Group Series, Booklet No.30, (Canadian Historical Association: Ottawa, 2006), 6.

84 Jason King and Kevin James, "Introduction," Canadian Journal of Irish Studies 31 (2005): 14. 
their ways he will speedily pronounce them unworthy of absolution. He positively threatens to excommunicate them. We all know what terrors these warnings have for the faithful, and that the Bishop has the power to bring his followers to their knees, no matter what may be their rank or position. They may resist at first, but if they want to remain connected with the Church, submission must ultimately be made. The Bishop is the representative of God's Vicegerent upon earth, he holds the scale of eternal life or death in his hands. That is the Romish doctrine...If anyone should dare to oppose his decrees, not only the culprit himself but his innocent family will undergo the ban of excommunication - "which open Hell and closes Heaven". Monstrous doctrine!-yet it is that of the rulers of Canada at the moment. We are bound hand and foot to men who acknowledge this faith, who cringe to a frail, fallible mortal, as if he were a God. The Government dare not disobey the orders of the Bishop, and until we have a thorough expression of the feelings of Upper Canada, we are tied fast to the chariot-wheels of Rome. ${ }^{85}$

Similar views were shared by various readers of the Globe, as was made clear by several letters to the editor that condemned the tyranny of Rome. The paper was all too willing to print letters like the following, which was signed A Protestant, published 18 July 1856:

I feel justified in speaking as I do, and believe that the present ministry are TRAITORS TO THIS PROVINCE AND IN LEAGUE WITH ROME TO ENSLAVE IT. They style themselves Conservative and Conservatives they are. Bishop Charbonnel is their master, and we are his serfs. For years, Cabinet after Cabinet has but one aim - the retention of power; and for years, this has been purchased by subserviency to Rome. Rome has sat in our Assembly, and commanded the vote. Rome has sat on our judgment-seat and subverted the laws. Wherever we turn we are met by an agent of Rome...I would implore Protestants to rouse then-Forget your differences!... One vigorous effort might defy the conspirators. We might yet save the country. Oh try! Rouse you from the lethargy of years. Be men of action as you are in fact. Do not leave a legacy of misery to generations yet unborn... So many villains never lorded it over us before. Let us show them that we will endure their yoke no longer. Remember the Bill of Rights, the glorious Revolution, William of Orange, your murdered fathers, your hearts and your God, and save the country. ${ }^{86}$ (Emphasis in original)

The Globe was of course operated by George Brown, who was both a small-1 and a

Globe (Toronto), 9 July 1856, p. 2, col. 4.

${ }^{86}$ Ibid. 
large-L liberal. ${ }^{87}$ Ian McKay argues that one can discern in Brown, along with other nineteenth-century liberals, the "underlying commitment to propertied improvement and development perfectibility," 88 which excluded from the liberal order those who were not seen to possess such beliefs. These exclusions, argued McKay, were not accidental, but rather the logical consequence of that very allegiance to liberal values. ${ }^{89}$ Within this field, Brown and others who promulgated anti-Catholic views believed that Catholics were to be excluded from the Canadian liberal order owing to their superstitious customs and adherence to irrational tribalism.

As a result of this hostile social environment, Irish Catholics in North America organized new societies whose professed purpose was ethno-religious defence. While I noted the formation of the Irish Catholic Union in Montreal as an example of these types of organizations, the most widely-known example of a militant Irish Catholic association was Toronto's Hibernian Benevolent Society. The HBS was founded in response to the $1858 \mathrm{St}$. Patrick's Day riot in Toronto, where an Irish Catholic, Matthew Sheedy, was killed. Citing the "intense bigotry and hatred" members of the Orange Order held toward their "more peaceably disposed fellow-subjects, the Roman Catholics," founders of the HBS asserted that the organization was formed in the interests of Irish Catholic self-defence. ${ }^{90}$ Peter Toner has argued that the most important accomplishment of the HBS was "to force Orangemen in Toronto stand down."

The Hibernian Benevolent Society belonged to a global movement of revolutionary

87 J.M.S. Careless, Brown of the Globe: Statesman of Confederation, 1860-1880, (Toronto: The Macmillian Company of Canada, 1963), vii.

88 Ian McKay, "Canada as a Long Liberal Revolution: On Writing the History of Actually Existing Canadian Liberalisms, 1840s-1940s." In Liberalism and Hegemony: Debating the Canadian Liberal Revolution, edited by Jean-François Constant and Michel Ducharme, (Toronto: University of Toronto Press, 2009 ), 397.

89 Ibid.

$90 \quad$ Irish Canadian (Toronto), 11 March 1863, p.4, col.1.

91 Peter M. Toner, "The Fanatic Heart of the North," in Irish Nationalism in Canada, edited by David A. Wilson, (Montreal and Kingston: McGill-Queen's University Press, 2009), 36. 
Irish Catholic nationalist organizations established during the same period. On 17 March 1858 "the organization” or the Irish Republican Brotherhood, was formed by James Stephens in Dublin. John O’Mahony formed a parallel organization in New York in April of 1859 called the Fenian Brotherhood. The Irish Republican Brotherhood, the Fenian Brotherhood, and the HBS all promoted the cause of Irish freedom and an end to British rule in Ireland. As will be shown in Chapter Six, Patrick Nolan, a government spy who infiltrated the Irish community of Toronto, found that members of the HBS were actively supporting the revolutionary aspirations of the Fenians. ${ }^{92}$ Brian Clarke has argued that while the number of Fenians in Toronto was probably low, around $100,{ }^{93}$ this was enough to dominate the HBS by holding key executive positions in the organization. Thus, Clarke concludes, the HBS became, wittingly or not, a front for the Fenian Brotherhood. ${ }^{94}$ Yet, as Reg Whitaker, Andrew Parnaby, and Greg Kealey observe, the Hibernian Benevolent Society and the Fenians were not the same thing. ${ }^{95}$ Peter Toner also argues that not all Hibernians were Fenians. ${ }^{96}$ Indeed, the HBS denied any affiliation with the Fenians. When, in 1864, editor of the Globe George Brown accused Murphy and the HBS of supporting the Fenian movement, Murphy responded by writing a letter to the Globe. In it, Murphy argued that the HBS was formed on the principles of benevolence and self-defense. He further argued that it was incumbent upon Irish Catholics to protect their own families and property from Orange excesses and aggression as a result of the unwillingness of authorities in Toronto to act on their behalf. While Murphy did admit that the HBS would always express a heartfelt sympathy with the Fenians or any organization whose objective was the freedom and prosperity of Irish people

92 Reg Whitaker, Gregory S. Kealey, Andrew Parnaby, Secret Service: Political Policing in Canada From the Fenians to Fortress America, (Toronto: University of Toronto Press, 2012), 22.

93 Clarke, Piety and Nationalism, 170.

94 Ibid.

95 Whitaker, Parnaby, Kealey, Secret Service, 25;

96 Toner, "The Fanatic Heart of the North," 48. 
on Irish soil, he argued that there was "no connection whatsoever between Fenianism and his organization. ${ }^{997}$ Murphy’s letter illustrates that the HBS supported the cause of Irish freedom and was formed within the global context of Irish Catholic nationalist movements. At the same time it also indicated that the HBS concerned itself with improving the plight of Irish Catholics in Toronto. As Murphy declared with much hyperbole, the protection of the HBS meant that Irish Catholics in Toronto would no longer be shot down like dogs. ${ }^{98}$ Owing to their revolutionary ideas, the HBS was thus a different organization from the Church-run and middle-class voluntary associations that dominated the Irish Catholic voluntary movement. ${ }^{99}$

Lay organizations such as the HBS were formed to counter what was seen as growing anti-Irish and anti-Catholic hostilities by the Protestant majority. ${ }^{100}$ Hostility begat hostility, as Catholics and Protestants fed off of the increasingly truculent attitudes of the other. ${ }^{101}$ Organizations shifted from those organized on ethno-charitable or clerical-community principles to ones in which Catholicism was a requirement of membership, and those advocating an uncompromising variety of Irish Catholic nationalism. More than responding to increased sectarianism in Canadian society, then, Irish Catholic voluntary associations such as the HBS in fact helped to construct this social environment.

\section{Membership and Leadership of Irish Catholic Voluntary Associations}

Irish Catholic voluntary associations, then, were formed for various reasons. Early

97 W.S. Neidhardt, "MURPHY, MICHAEL," in EN:UNDEF:public_citation_publication, vol. 9, University of Toronto/Université Laval, 2003-, accessed June 3, 2014, http://www.biographi.ca/en/bio/murphy_michael_9E.html.

98 Clarke, Piety and Nationalism, 195.

99 Ibid., 182. Clarke also notes the working class composition of the HBS.

100 Toner, "The Fanatic Heart of the North," 48.

101 David A. Wilson, "The Fenian World of Jeremiah Gallagher," Canadian Journal of Irish Studies, Volume 39, Volume 1 (2015): 30. Though Wilson notes that the presence of the Orange Order was not necessary to stimulate Irish radical nationalism, he does observe that in Toronto at least, Fenianism and Orangeism fed off one another. 
ecumenical groups like the CIS in Halifax and the BIS in St John's were formed on benevolent and charitable principles. Increased numbers of Irish Catholics in Canada, the growing influence of ultramontanism within the Catholic Church, the development of ethnoreligious consciousness among this group, and the sectarianism of Canada in the 1840s led to the establishment of new societies with different aims. Catholic associations aimed to establish clerical community leadership, while more nationalist associations such as the HBS were formed to unite Catholics in an increasingly hostile social environment. Despite ethnic identity being central in Irish Catholic voluntary associations, marking these societies off from the liberal societies studied by Darren Ferry, and despite the fact that Irish Catholic voluntary associations became increasingly sectarian throughout the century and in doing so challenged the dominance of Protestantism within the emergent Canadian state, these organizations facilitated social mobility and engaged in significant dialogues with state and society.

These organizations allowed members to retain their Irishness and rework that sense of identity within Canadian culture that they were an increasingly growing and influential part. As in the research of Mary Treudly and Helen Znaniecki Lopata referenced in the previous chapter, ${ }^{102}$ one of the major questions this study seeks to answer is the extent to which participation in Irish Catholic voluntary associations facilitated or retarded the integration of its members. Treudly found that voluntary associations within the Greek community of Boston aided in the integration and eventual advancement of members, while Znaniecki Lopata found that Polish voluntary associations slowed the rate of integration of its members in Chicago. This study has found that, as in Treudly's research among Boston's

${ }^{102}$ Mary Bosworth Treudly, "Formal Organization and the Americanization Process with Special Reference to the Greeks of Boston," American Sociological Review 14 (February 1949): 44; Helen Znaniecki Lopata, "The Functions of Voluntary Associations in an Ethnic Community: 'Polonia'," in Contributions to Urban Sociology, ed. Ernest W. Burgess and Donald J. Bogue (Chicago: University of Chicago Press, 1964), 203. 
Greek community, membership in Irish Catholic voluntary associations did not decelerate the successful integration of its members. Indeed, for the very elite of Canadian Irish Catholic society, membership in ethnic voluntary associations did not cut them off from social advancement and social mobility, and indeed, as later chapters will relate, it helped them become self-governing individuals with the liberal values and respectable attributes not only to succeed in material terms, but to make claims to equal status in the wider society and government. It would only be in the 1870 s that they would organize to push against the exclusions and limitations of the British Canadian liberal order that McKay and others emphasize so strongly.

Two sources useful for studying social standing and material success are city directories and biographical dictionaries. These dictionaries include the five volumes of The Canadian Album: Men of Canada; Or, Success by Example in Religion, Patriotism, Business, Law, Medicine, Education and Agriculture, the two volumes of The Canadian Biographical and Portrait Gallery of Eminent and Self-Made Men, and the two volumes of A Cyclopaedia of Canadian Biography: Being Chiefly Men of the Time. These dictionaries were published in order to inform the public of the "leaders of thought and action in the towns, cities, townships, and counties of Canada"103 and based on the belief that "the world worships success, and is glad to learn how it has been brought about." ${ }^{104}$ I collected the names and biographical information of all the Irish Catholic entries and created a data-set based on the information contained therein. With this information, I have been able to determine the occupational profile of the Irish Catholics in the dictionaries. The inclusion of

103 Rev. William Cochrane, The Canadian Album. Men of Canada; or Success by Example in Religion, Patriotism, Business, Law, Medicine, Education and Agriculture, Vol. 1, (Bradley, Garreston \& Co.: Brantford, Ontario, 1891), 4.

104 The Canadian Biographical Dictionary and Portrait Gallery of Eminent and Self-Made Men, Ontario Volume, (American Biographical Publishing Company: Chicago, New York, and Toronto, 1880), 3. 
Irish Catholics in these biographies recognized them as successful within their ethno-

religious milieu, and also by objective measures of liberal standards of success.

Table 2.1: Irish Catholics in Biographical Dictionaries ${ }^{105}$

\begin{tabular}{|l|l|l|}
\hline Name of Biographical Dictionary & Total Number of Biographies & $\begin{array}{l}\text { Total Number of } \\
\text { Irish Catholics }\end{array}$ \\
\hline $\begin{array}{l}\text { The Canadian Album: Men of Canada or Success } \\
\text { by Example. (Five Volumes) }\end{array}$ & 2763 & 159 \\
\hline $\begin{array}{l}\text { A Cyclopaedia of Canadian Biography. (Two } \\
\text { Volumes) }\end{array}$ & 1849 & 101 \\
\hline $\begin{array}{l}\text { Canadian Biographical Dictionary and Portrait } \\
\text { Gallery of Eminent and Self-Made Men (Two } \\
\text { Volumes) }\end{array}$ & 1103 & 54 \\
\hline
\end{tabular}

The total number of Irish Catholics listed in these dictionaries was 294. ${ }^{106}$ This

number represents a rather paltry $5 \%$ of the total number of biographies. Of the 294 Irish

Catholics in these dictionaries, 65 were listed as being members of Irish Catholic voluntary

associations, which represents $22 \%{ }^{107}$ Moreover, the biographies do not mention any

105 William Cochrane, The Canadian Album. Men of Canada; or Success by Example in Religion, Patriotism, Business, Law, Medicine, Education and Agriculture, Vol. 1, (Brantford, Ontario: Bradley, Garreston \& Co., 1891); William Cochrane, The Canadian Album. Men of Canada; or Success by Example in Religion, Patriotism, Business, Law, Medicine, Education and Agriculture, Vol. 2, (Brantford, Ontario: Bradley, Garreston \& Co., 1893); William Cochrane, The Canadian Album. Men of Canada; or Success by Example in Religion, Patriotism, Business, Law, Medicine, Education and Agriculture, Vol. 3, (Brantford, Ontario: Bradley, Garreston \& Co., 1894); William Cochrane, The Canadian Album. Men of Canada; or Success by Example in Religion, Patriotism, Business, Law, Medicine, Education and Agriculture, Vol. 4, (Brantford, Ontario: Bradley, Garreston \& Co., 1895); J. Castell Hopkins, The Canadian Album: Encyclopedic Canada, or The Progress of a Nation in Religion, Patriotism, Business, Law, Medicine, Eeducation and Agriculture, Vol. 5, (Brantford, Ontario: The Bradley-Garreston Company Ltd., 1896); George MacLean Rose, $A$ Cyclopaedia of Canadian Biography: Being Chiefly Men of the Time, Vol. 1, (Toronto: Rose Publishing Company, 1886); George MacLean Rose, A Cyclopaedia of Canadian Biography: Being Chiefly Men of the Time, Vol. 2, (Toronto: Rose Publishing Company, 1888); The Canadian Biographical Dictionary and Portrait Gallery of Eminent and Self-Made Men, Ontario Volume, (Chicago, New York, and Toronto: American Biographical Publishing Company, 1880); The Canadian Biographical Dictionary and Portrait Gallery of Eminent and Self-Made Men, Quebec and Maritime Provinces Volume. (Chicago, New York, and Toronto: American Biographical Publishing Company, 1881).

106 This number is smaller than the total number of Irish Catholics listed in the table below because that number includes all Irish Catholics listed in all the dictionaries, while the number of 294 excluded repeating entries in the dictionaries.

${ }^{107}$ Of this group, there were 19 merchants, 17 lawyers or judges, six doctors, six government workers, six 
significant participation in non-Irish and non-Catholic voluntary associations. This data is likely problematic. That just over $20 \%$ of Irish Catholic biographees were listed as involved with Catholic associations must be under-reporting, or an exclusion based in the interest of space, where biographees often received only a quarter page including a picture. Still, if they under-reported that, they may also have under-reported membership in associations that crossed the religious divide. In terms of an occupational profile of Irish Catholics in the dictionaries, 74 were merchants or involved in business, 68 were members of the clergy, 66 were lawyers, judges, or magistrates, 24 were doctors of medicine, 20 were builders or contractors, 15 were employed in the government or civil service, nine were newspaper editors or journalists, four were engineers, three were members of the police, two each were dentists, architects, teachers, and members of the military, while there was one veterinarian, one druggist, and one accountant.

The low representation of Irish Catholics raises the question of economic and social mobility among the community in the nineteenth century, and as yet the scholarship does not offer an agreed-upon conclusion to the topic. Gordon Darroch and Michael Ornstein found the Irish experienced economic stagnation relative to other ethnicities, with $60 \%$ remaining labourers over the decade 1861-1871 compared with 23\% of Irish Protestants. ${ }^{108}$ William Smyth notes that any improvement in the occupational profile of Toronto's Irish Catholics in the latter part of the nineteenth century can be accounted for by the development of Toronto itself as a commercial centre of national importance. Structural shifts in the commercial economy created an increasing demand for clerical workers and Irish Catholics were able to take advantage of the transforming economy. Outside of this, Smyth argues, the Irish

clergy, four builders/contractors, four journalists, one dentist, one accountant, and one teacher. 27 members of this group ran for political office.

${ }^{108}$ Gordon Darroch, "Half Empty or Half Full? Images and Interpretations in the Historical Analysis of the Catholic Irish in Nineteenth-Century Canada." Canadian Ethnic Studies 25, no. 1, (1993): 5. 
Catholic population did not advance in fields such as architecture, civil engineering, or medicine. ${ }^{109}$ William Jenkins advances a rather more nuanced position. He argues that Irish Catholics were in fact becoming economically and socially mobile in the 1880 s and 1890 s. However, Jenkins argues that their advancement was belied by the fact that they did not break into Protestant social circles or business networks. Looking at the names of pallbearers and chief mourners for middle- and upper-class Irishmen in Toronto, Jenkins found that they attracted relatively few mourners from the other side of the sectarian divide. ${ }^{110} \mathrm{He}$ concludes that the persistence of such denominational separations frustrated incorporation within Protestant social circles. ${ }^{111}$ Thus, based on the data in the biographical dictionaries, the argument advanced by Jenkins, and the campaign for political and patronage representation that occurred in the 1870 s, it seems likely that Irish Catholics were achieving social and economic mobility in the wider society, but they largely remained within their own social milieu.

Another invaluable source were city directories, which often published a list of the various voluntary associations located in their district, and members of the executive committees of these organizations. Using this information, I have taken the names of officers and committee members and cross-referenced them with census and city directory information in an attempt to establish a prosopographical social profile of the societies' leadership with such information as age, place of birth, marital status, and occupation. It is difficult to perform such research in general, and perhaps especially with the Irish, owing to the commonness of certain names, particularly in largely populated centres such as Montreal

109 William Smyth, Toronto, The Belfast of Canada: The Orange Order and the Shaping of Municipal Culture, (Toronto: University of Toronto Press, 2015), 149. The larger implications of Irish Catholics taking advantage of new opportunities in a changing economy, not in itself a bad thing, is not discussed by Smyth.

110 William Jenkins, "Deconstructing Diasporas: Networks and Identities Among the Irish in Buffalo and Toronto. 1870-1910," Immigrants and Minorities Volume 23 Issue 2-3 (2005): 384.

${ }^{111}$ Ibid. 
or Toronto. For instance, I had difficulty matching the John Murphy from the city directory list of an organization with the multiple John Murphys in the census and city directories. Moreover, if the name is listed as simply "J Murphy" there is even greater confusion is ascertaining whether or not I am inputting the statistical information of the correct $\mathrm{J}$. Murphy. To avoid claiming too much, I have discarded names if there are more than three of one name in the census or city directory records, unless, however, all of the names indicate they were born in Ireland and they were all married working in retail. But this approach also presents problems because there is a difference between working as a tailor and owning a clothing store, though both could be considered retail/commercial workers. Moreover, in many instances, two of the same name cancel each other out with contrasting information. Supposing, for instance, that the first Francis O'Neill in the census was born in Ireland, was married, had three children, and owned a grocery store, but the other Francis O'Neill was born in Canada, was unmarried, and a day labourer. In this instance, then, we can never really know the Francis O'Neill that was listed as an officer in the Irish Catholic voluntary association. Nevertheless, if both Francis O'Neill's were born in Ireland, but had a different marital status and different occupations, we then at least determine that Francis O'Neill was born in Ireland, even if we cannot know other demographic information. ${ }^{12}$

Certain characteristics can be teased out of this analysis of membership, flawed though it may be. The tables above show that even as late as 1880, a high percentage of the members of committees were born in Ireland. This suggests that the organizations were lead by individuals who had for some time been at the forefront of Irish Catholic cultural life. This Irish-born leadership was indicative of the fact that this generation helped shape the contours of the Irish Catholic community, and the associations representing the interests of

${ }^{112}$ For these tables, please see Appendices C-H. 
that community. It further suggests a hierarchical social structure within the community in which age and experience counted toward authority and thus allowed for those individuals to be placed into positions of community leadership. The leadership seem mostly to be merchants and professionals at the outset, but by mid-century included large numbers of the skilled working class gaining office over time.

Women did not have much of a voice in these organizations, and leadership positions, as well as membership, were largely, if not wholly, male. ${ }^{113}$ Unlike the mainstream temperance movement, women did not actively participate in Catholic temperance, especially after the 1850 s. Female associational involvement consisted of organizing charitable efforts to aid Irish orphans, notably church bazaars. In some instances female Irish Catholics did organize their own associations, such as the Society of Ladies of Charity of St Patrick's Congregation in Montreal in the 1880 s. This society consisted of wives of male leaders in Montreal's Irish Catholic community, including the wives of Edward Murphy, Thomas Ryan, and William Brennan and was under clerical control, with Father Patrick Dowd listed as the director of the society. ${ }^{114}$

Regional variation with respect to the types of associations was limited, as clericotemperance, national, and self-improvement societies existed across Canada. The exception, which will be explored in more depth later in this dissertation, is the Catholic League in Ontario. There were calls in other provinces to increase the number of Irish Catholics to public office, but the Catholic League seems to be the sole instance of an organized effort on the part of Irish Catholics to make these calls into a reality through agitation and action.

\footnotetext{
113 Terrence Murphy, "Trusteeism in Atlantic Canada: The Struggle for Leadership Among the Irish Catholics of Halifax, St John's, and Saint John, 1780-1850," in Creed and Culture: The Place of English-Speaking Catholics in Canadian Society, 1750-1930, edited by Terrence Murphy and Gerald Stortz (Montreal and Kingston: McGill-Queen's University Press, 1993), 126-127. This point will be taken up further in the following chapters.

114 Lovell's Montreal City Directory, Society of Ladies of Charity of St Patrick's Congregation, 772.
} 
Given the incendiary character of Globe articles in the 1850s and 1860s, it is likely that the context of Ontario as a hotbed of Orangeism and Loyalist traditions contributed to the feeling of persecution felt by Irish Catholics in the province. As will be discussed further, the response of authorities to the Fenian Raids of 1866 only served to heighten such feelings among the Irish, and this also contributed to the formation of the Catholic League.

\section{Conclusions}

This chapter has shown how illiberal the Church could be and how it tried to use voluntary associations as a measure of social control over its members. The most important developments in this period for the Irish Catholic community were the ascent of ultramontanism, the growing global power of Irish prelates, the rise of sectarianism, and the development of an ethno-religious consciousness. All of these transformations were reflected in the changing nature of Irish voluntary associations. The period between the formation of early ecumenical Irish voluntary associations in the late-eighteenth and early-nineteenth centuries and the 1880 s witnessed a rise in sectarianism. This process included confessionalization of existing, originally elite, organizations at mid-century, and the formation of militant lay organizations such as the Hibernian Benevolent Society to counter anti-Catholicism and Orange hostility.

Despite the increased emphasis on Catholicism in the Irish Catholic associational world in the 1850s and the rise of sectarianism, Irish Catholics did not cloister themselves away from society. The societies and members were actively involved in developments in the wider Canadian society. Irish Catholic voluntary associations tended to be arenas for ambitious Irish Catholics to gather support from among their community to use in politics. Typically, individuals would experience success in business, increase their profile in the 
societies, then use the social and cultural capital they garnered in these positions to stand for elected office an/or increase their business interests. Irish Catholic voluntary associations were in a sense alternative publics, spaces for Irish Catholics to function, as inclusion into Protestant society was made difficult due to sectarian loyalties. Still they were not operating in a social, cultural, or political vacuum. Instead, members of Irish Catholic voluntary societies, and the societies themselves, engaged with broader issues in liberal Canada, as we shall see in later chapters. 
Chapter Three: Irish Catholic Clergy and Catholicism in the Temperance Crusade.

\section{Introduction}

The focus of this chapter is on the Catholicity of the Irish Catholic temperance movement, elaborating upon the theme of the previous chapter, which centered on how the Catholic hierarchy contested both liberalism and state formation. The force of organized religion opposed the intrusion of the liberal state into the everyday lives of Catholics. Catholic commentators even denounced legislative enactments prohibiting the production and sale of alcohol as "tyrannical measures" and constructed the Church as the moral guide of the selfgoverning individual. Through the theological thrust of the Irish Catholic temperance movement, the hierarchy denied the state a moral jurisdiction over the lives of Catholics.

Temperance emerged as part of the Second Great Awakening in the United States in the 1790s. It became widespread across the Atlantic World and the British Empire in no small part owing to the temperance missionary work undertaken by Protestant evangelical organizations associated with religious revivalism. ${ }^{1}$ Temperance originated within the evangelical culture of the United States and through the work of these evangelical Protestant groups espousing the self-control ethos of temperance it soon became an important issue across the globe. ${ }^{2}$ Historians have viewed temperance largely as a Protestant social

1 Ian Tyrell, Woman's World, Woman's Empire: The Woman's Christian Temperance Union in International Perspective, 1880-1930, (Chapel Hill \& London; University of North Carolina Press, 1991). For this point see especially Chapter One: "Origins of Temperance Internationalism."

2 The literature on temperance is vast. Among others see for the United States Joseph R Gusfield, Symbolic Crusade: Status Politics and the American Temperance Movement (Urbana: University of Illinois Press, 1963); Jack S Blocker, American Temperance Movements: Cycles of Reform (Boston: Twayne Publishers, 1989); Holly Berkley Fletcher, Gender and the American Temperance Movement (New York \& London: Routledge, 2008); For Canada see Jan Noel, Canada Dry: Temperance Crusades Before Confederation (Toronto: University of Toronto Press, 1995); Craig Heron, Booze: A Distilled History (Toronto: Between the Lines Press, 2003); For England see Brian Howard Harrison, Drink and the Victorians: The Temperance Question in England, 1815-1872 (London: Faber and Faber Inc., 1971); James Nicholls, The Politics of Alcohol: A History of the Drink Question in England, (Manchester \& New York: Manchester University Press, 2009); For South Africa See Paul Nugent, "The Temperance Movement and Wine Farmers at the 
movement. ${ }^{3}$ Deirdre Moloney goes so far as to say that readers of these works "are often left with the impression that Catholics were opposed or indifferent to temperance." ${ }^{4}$ But as Moloney and others have shown, this was not the case: Catholic temperance societies emerged across North America as the Church expanded its infrastructure and the Catholic population increased.

There existed significant differences between Protestant and Catholic temperance movements, with Protestant organizations increasingly aiming for state mandated prohibition. From the formation of the earliest temperance societies in the 1820 s to midcentury, Protestant temperance societies employed a moral suasion approach emphasizing individual reformation through moral agency. Darren Ferry argues that following the Maine Laws of 1851, which prohibited the sale of all alcoholic beverages except for medicinal, mechanical, or manufacturing purposes and the adoption of similar laws in other American jurisdictions, Protestant temperance societies such as the Canadian Sons of Temperance came to feel that moral suasion was no longer effective. ${ }^{5}$ Catholic temperance, on the other hand, did not look to the state to curb alcohol consumption; rather, they relied on an ethos of moral suasion that was grounded in Catholic teaching. Catholic temperance societies continued to preach the merits of individual moral reformation rather than state-enforced liquor laws. This was one of the ways in which the Catholic Church resisted the intrusion of

Cape: Collective Action, Racial Discourse, and Legislative Reform, 1890-1965," The Journal of African History, 52 no. 2 (2011): 341-363; For Australia see Diana Christine Noyce, "Coffee Palaces in Australia: A Pub with no Beer," M/C Journal 15 no. 2 (2012); Anna Blainey, "The Prohibition and Total Abstinence Movement in Australia, 1880-1910," in Food, Power and Communities: Essays in the History of Food and Drink, ed. Robert Dare, (Adelaide: Wakefield Press, 1999); For the broad international perspective on temperance see Jack S. Blocker, David M. Fahey, Ian R. Tyrell, Alcohol and Temperance in Modern History: An International Encyclopedia, (Santa Barbara: ABC-CLIO, 2003).

3 Berkley Fletcher, Gender and the American Temperance Movement, 94.

4 Deirdre Moloney, American Catholic Lay Groups and Transatlantic Social Reform in the Progressive Era (Chapel Hill\&London: University of North Carolina Press, 2002), 43.

5 Darren Ferry, Uniting in Measures of Common Good: The Construction of Liberal Identities in Central Canada, 1830-1900, (Montreal and Kingston: McGill-Queen's University Press, 2008), 109. 
the state into moral and educational areas it felt were properly within its own jurisdiction. Ferry also argues that women took a more prominent role in the Protestant temperance movement, which was a training ground for them to move into the public sphere. Though women were active in Catholic temperance societies during their earliest decades, after 1860 Catholic temperance societies were male organizations in both leadership and membership, and women's activities were largely confined to parish confraternities and social fundraising events. The roles of women will be explored further in Chapter Five.

Organizationally, the mainstream temperance movement shifted from temperance pledge societies to self-help mutual benefit societies, composed of local divisions, in the 1840s. ${ }^{6}$ Catholic temperance associations, in contrast, were grounded in local parishes and dioceses. They were typically organized in a spontaneous manner and depended upon the enthusiasm of local clerics, though occasionally reforming bishops encouraged the movement as Ignace Bourget did in the Diocese of Montreal by employing Charles Chiniquy as a traveling evangelist of temperance. Bourget was also a fierce ultramontane. Echoing the mainstream movement's more centralized organizational structure, and seeking greater concentrated clerical control, national and international Catholic temperance societies were founded in the 1870s and 1880s, such as the American-based Catholic Total Abstinence Union and British-based League of the Cross. Parish and diocesan temperance societies became linked to these national and international organizations. Following the collapse of the CTAU in Canada, the Catholic movement remained under the control of the hierarchy, with some diocesan temperance societies established in lieu of the provincial ones. Thus, despite the burgeoning of these larger organizations, the movement remained centered around dioceses and parishes, and were controlled by the Catholic hierarchy. Clergy issued

6 Ibid, 102-3. 
injunctions to the Irish Catholic community to lead religious, sober, and productive lives and made sure that the practices and theology of the Catholic Church were embedded within the movement. Irish Catholic temperance societies were part of the global movement among the Irish diaspora in which Catholic clergy aimed to place themselves in roles of community leadership through parish-organized associations and keep their Catholic flock separate from mainstream Protestant society. At the same time as the Catholic temperance movement was strengthening its position among Canadian Catholics, the mainstream temperance movement was organizing national organizations to lobby the state to curb alcohol consumption through prohibitory legislation. Canadian clerics adhering to ultramontanist beliefs regarding papal authority over Catholic populations, however, resisted state attempts to control the drinking habits of the population. In doing so, Catholic temperance advocates challenged the expansion of Canadian state functions.

\section{Irish Catholics in the Global Temperance Movement}

One of the most successful temperance campaigns originated in Ireland and was led by Capuchin monk Theobald Mathew. ${ }^{7}$ Organized temperance came to Ireland through the work of Rev. Joseph Penney, a Presbyterian minister who belonged to a branch of the religion known as Seeders. Penney emigrated to New York State in 1819 and became active in the temperance movement. In 1829 he returned to his native Ulster to spread the temperance message. Penney convinced his fellow Seeder John Edgar to take up the cause, and in September 1829 Edgar, along with four ministers and one layman, founded the Ulster Temperance Society in Belfast. ${ }^{8}$ Mathew came to temperance through The St Nicholas

7 Rev. W.H. Cologan and Sir Francis Richard Cruise, The Catholic Temperance Reader, (London: Catholic Truth Society, 1900), 147.

8 John F. Quinn, Father Mathew's Crusade: Temperance in Nineteenth-Century Ireland and Irish America, (Amherst and Boston: University of Massachusetts Press, 2002), 47. 
Society, a temperance society formed in 1830 in Cork by a Quaker merchant and a Catholic ex-soldier, with a committee dominated by Quakers and supported mostly by "Liberal Protestants." "An anti-Catholic lecture given by a visiting clergymen caused the Catholics to withdraw from the society and urge Mathew to organize a Catholic teetotal association. ${ }^{10}$ Mathew was not a member of the St Nicholas Society, but they believed he would be sympathetic to their cause. At their behest, Mathew formed the Cork Total Abstinence Society in $1838 .{ }^{11}$ Mathew's temperance crusade would have a major impact both in Ireland and abroad, with supporters estimating that Mathew enrolled somewhere between three and five million people into the movement. ${ }^{12}$ Mathew's temperance movement attracted especially a rising Irish Catholic middle-class who had been "emancipated" by Daniel O'Connell's political campaign of the $1820 \mathrm{~s}^{13}$ This group infused its temperance campaign with distinct meanings that would be carried across the globe by Irish Catholics who engaged in temperance activities wherever they settled. The effect of this was to present temperance as a way to achieve spiritual and material self-improvement and regeneration for both the individual and the collective Irish nation. The temperate individual was not the end, argued historian Paul Townend, but rather "the beginning of a regenerated Ireland and a new social order." 14

In the United States, Irish Catholic temperance societies formed as a direct result of Father Mathew's American tour of the late 1840s. ${ }^{15}$ For instance, in October of 1849 Mathew

$9 \quad$ Elizabeth Malcolm, Ireland Sober, Ireland Free: Drink and Temperance in Nineteenth Century Ireland (Syracuse: Syracuse University Press, 1986), 109-110.

10 Ibid., 110.

11 Quinn, Father Mathew's Crusade, 58.

Quinn, Father Mathew's Crusade, 112.

13 Daniel O'Connell led the movement for Catholic Emancipation in the 1820s, which aimed to reduce and remove many of the restrictions on Roman Catholics imposed by various Acts of the British Government.

14 Paul A. Townend, Father Mathew, Temperance and Irish Identity, (Dublin: Irish Academic Press, 2002), 856.

15 John F. Quinn, “Father Mathew's American Tour,” Éire-Ireland 30 (Spring1995): 91. 
visited East Cambridge, Massachusetts where his efforts resulted in over 1300 men signing the total abstinence pledge. Two months after Mathew's visit, a local total abstinence society was formed. This society was under the influence of the parish priest Father Carroll who requested that the society hold its meetings in the basement of the Church, a request the society accommodated. ${ }^{16}$ Mathew also organized the Father Mathew Society of Worcester, Massachusetts during his 1849 visit to that city, and he administered the pledge to thousands in St Louis in October $1850 .{ }^{17}$

Mathew was indeed influential in extending temperance among the global Irish diaspora. Townend has argued that Mathew's popularity was spread by Irish emigrants, as halls, statues, towers were later erected across Ireland, Australia, Britain, and the United States in honour of his successes. ${ }^{18}$ Yet along with the importance of Mathew, Irish Catholic clerics who supported temperance also played a fundamental role in organizing temperance societies. In Australia, the first Irish Catholic temperance society was formed under the auspices of Irish priest John T. Lynch. Lynch trained at the seminary at Maynooth, where Mathew was influential. According to Mathew's 1841 memoir, 250 students and eight Professors at the Maynooth seminary had taken the temperance pledge to that point. ${ }^{19}$ Lynch, along with four other Irish born and trained priests, arrived in Sydney aboard the Cecilia on 15 July 1838. They were meant to establish a Catholic infrastructure in colonial New South Wales. One of Lynch's first efforts in this endeavor was the establishment of an Irish Catholic temperance society, the St John's Total Abstinence Society in West Maitland on 15

16 The Sacred Heart Review (Boston) 1 December 1888, p. 6, col. 2. This publication was the organ of the Catholic Church in Cambridge and Boston and was published between 1888 and 1918.

17 Joseph C. Gibbs, History of the Catholic Total Abstinence Union of America, (Philadelphia: Penn Printing House, 1907), 199.

18 Paul A. Townend, "Matthewite Temperance in Atlantic Perspective," in The Irish in the Atlantic World edited by David T. Gleeson, (University of South Carolina Press, 2010), 19.

19 A Memoir of the Very Rev. Theobald Mathew, edited by P.H. Morris, (New York: Alexander V. Blake, 1841), 1. 
August 1841. Lynch biographer John O'Brien notes that Lynch, inspired by Father Mathew's crusade, designed to "take the thing (alcohol) by the throat." ${ }^{20}$ Such temperance societies were part of the establishment of the Irish spiritual empire, explained in the previous chapter.

The increase in the numbers of Irish Catholics who arrived in Canada since the 1820 s, as well as the growing popularity of temperance among the Irish Catholic diaspora at this juncture, resulted in the temperance movement becoming one of the first mass social reform efforts undertaken by clerical and lay Irish Catholics in Canada. ${ }^{21}$ In Montreal in 1840, Irish born Sulpician Patrick Phelan established the first Irish Catholic temperance society in Canada. In an article announcing his death in 1857, the organ of Irish Catholics in Montreal, The True Witness and Catholic Chronicle remarked that Phelan exemplified the "good shepard" who "gave his life for the sheep."22 Phelan was born in County Kilkenny in 1793. After running out of funds to continue his education, he became a teacher in a private school. Soon after, he decided to leave for the United States to continue his education. He left Dublin on a ship destined for Boston in 1821. Three months later, Phelan was sent to Montreal by the prelate of Boston to study for the priesthood. Upon completion of his studies, Phelan was ordained as a priest on 24 September 1825, and was soon aggregated to the Seminary of St. Sulpice. Following this, he was active in ministering to the spiritual and temporal needs of the Irish Catholic community of that city and provided medical care during the cholera epidemics of 1832 and $1834 .{ }^{23}$ Though his temperance activities were influenced by the work of Mathew, as the outline of the history of St Ann's Total Abstinence and Benefit Society of Montreal suggests, Phelan seems to have been influenced as much by

20 John O'Brien, The Men of '38 and Other Pioneer Priests, (Kilmore: Lowden Publishing Co., 1975), 91.

21 The Repeal movement was also popular among Irish Catholics, with Canadian branches emerging in the 1830s advocating for a repeal of the union between Ireland and Great Britain.

22 True Witness and Catholic Chronicle (Montreal), 12 June 1857, p. 4, col. 4.

23 Ibid. 
his own experiences in Montreal during the cholera epidemics as he was by the Irish apostle of temperance. Seeing the destruction wrought by cholera, Phelan's temperance work was an extension of his desire to improve the lives of the poor and destitute of Montreal.

Phelan organized the Montreal association after vespers on Sunday 23 February 1840 in the Recollet Church, of which he was pastor. He addressed the members of the congregation on the evils of intemperance, and sought to form those in attendance into a society to combat the excessive consumption of alcohol. Following Phelan's address over 300 men joined the society, which was called the Irish Roman Catholic Temperance Association of Montreal. On 21 February 1841, the name of the Society was changed to the Irish Catholic Total Abstinence Society, and from that point only total abstainers were admitted as members. Prior to this, there was no distinction made between those who took the total abstinence pledge and those who took the temperance pledge. In 1843, the Society participated in laying the cornerstone of St Patrick's Church, and in 1847 the Society changed its name once again to the St Patrick's Total Abstinence Society, just a short time before St Patrick's Church was opened. ${ }^{24}$

In the United States, temperance became an Irish specific issue owing to the relative lack of enthusiasm demonstrated by German Catholics, the next largest Catholic population in the country. ${ }^{25}$ In Canada, by contrast, enthusiasm for temperance existed among French Catholics. The creation of Catholic temperance societies was promoted by the ultramontane Ignace Bourget, who became bishop of Montreal in 1840. Jan Noel argues that in many ways, Bourget was an effective social reformer as Montreal's population increased in the 1840s. He established orphanages, asylums, and schools in response to the "grave concerns

24 Souvenir of the Golden Jubilee of St. Patrick's T.A.\&B Society, 1840-1890 (Montreal: Dominion Illustrated Co., 1890), 22-25.

25 Moloney, American Catholic Lay Groups, 50. 
of the day." ${ }^{26}$ Noel argues that at this point the ultramontane wing of the Church had yet to assume its classic conservative perspective, and that Bourget was a "thoroughly modern man of the 1840 's," as he identified more with the reforming middle classes than with the aristocracy. ${ }^{27}$ One modern reform that Bourget espoused was temperance, which he, unlike his predecessor Bishop Jean-Jacques Lartigue, did not dismiss as a Protestant cause. Yet, despite Noel's assertion that his modernness was why Bourget advanced the temperance cause, she also notes that one of Bourget's aims in establishing temperance societies was to replace the political clubs of the Rebellion era with organizations aligned with clerics. ${ }^{28}$ In other words, Bourget employed temperance as a means to grow and extend Church authority in the post-Rebellion period. Toward this objective, Bourget recruited the fiery orator Charles Chiniquy to advance the temperance cause amongst his French-speaking flock.

Chiniquy served as chaplain at the Marine and Emigrant Hospital in the 1830s where he met Dr. James Douglas, a Scottish Methodist minister. It was Douglas who introduced Chiniquy to temperance, after showing him the destruction wrought by alcohol. With Bourget's support, Chiniquy founded a temperance society on 29 March 1840, which 1300 parishioners joined. Chiniquy used his public platform to advance ultramontanism, proclaiming the rights of the Church and the duty to submit to the pope. ${ }^{29}$ Bourget, Chiniquy, and other Catholic clergy in Canada sought to employ temperance societies as a way to grow and strengthen Catholic infrastructure in Canada with church-based confraternities such as temperance societies placing the parish at the center of the Catholic community, with the ultramontane Bishop Bourget, taking Chiniquy on as a traveling temperance promoter for

26 Jan Noel, "Dry Patriotism: The Chiniquy Crusade," Canadian Historical Review 71, no. 2 (1990): 194.

Ibid.

28 Noel, "Dry Patriotism," 205.

29 Ibid., 200. 
just this purpose. ${ }^{30}$

Chiniquy's temperance crusade paralleled the Irish one in many ways. Jan Noel argues that Chiniquy employed temperance as a means to achieve collective respectability and national regeneration, as well as an instrument to consolidate clerical control over Catholics' lives in the aftermath of the Rebellions of 1837-8 when anti-clerical Patriote leaders were in exile. ${ }^{31}$ Bourget's and Chiniquy's temperance crusade was part of a broader process in which people rejected radical politics in favour of conservative clerical leadership. ${ }^{32}$ That Phelan's organization predated Chiniquy's society by one month indicates that Phelan was not moved by the popularity of Chiniquy's movement to establish his own temperance society. Though the fact that a French-speaking and an English-speaking temperance society were established just one month apart, and in the context of the rising tide of temperance in both North America and Ireland, points to the fact that the move to temperance was an endeavour by the Catholic hierarchy to reach out to parishioners.

Given Bourget's support for temperance, his objective to use temperance societies to extend Church authority, the fact that he recruited Chiniquy in 1840, and his friendship with Phelan, it would be logical to assume that Bourget also played a role in helping Phelan establish his temperance society in 1840 . However, if such links existed, they were not documented by the Irish Catholic population of Montreal. In the Souvenir of the Golden Jubilee of St Patrick's T.A. \& B. Society, a booklet outlining the history of the society, it was emphatically stated that Patrick Phelan acted alone in establishing the organization in 1840. Described as "saintly, zealous, indefatigable, and fearless," Phelan was said to have

\footnotetext{
30 Yves Roby, “CHINIQUY, CHARLES," in Dictionary of Canadian Biography, vol. 12, University of Toronto/Université Laval, 2003-, accessed March 21, 2016,http://www.biographi.ca/en/bio/chiniquy_charles_12E.html.

31 Noel, "Dry Patriotism," 190.

32 Ibid.
} 
"gathered his people together and enrolled them in the noble army of Temperance." ${ }^{33}$ In an 1894 article outlining the history of St Ann's Total Abstinence and Benefit Society of Montreal, it was noted that because "the sacred cause of total abstinence has ever found numerous and staunch champions among the Irish race," it was no surprise that one of the first thoughts of Irish migrants who settled in Montreal was to "perpetuate the memory of that great apostle of temperance, Rev. Father Mathew, by organizing themselves here into societies for the propagation of that sentiment of total abstinence...(a)s the Irish people multiplied in Montreal so did the number of adherents to the principle of total abstinence, and as a natural consequence the spread of Irish Catholic temperance societies became as spontaneous as it did popular." 34 These hagiographical accounts of the founding of Irish Catholic temperance associations in Montreal suggest that the cause was motivated purely by issues internal to the Irish diasporic community in Canada. Within Irish memory, then, there were no links between French Catholic and Irish Catholic temperance, despite the fact that both organizations were established in the context of a rising tide of temperance in both North American and Ireland.

Despite their common religion and shared temperance support, as well as feeling themselves to be besieged minority out-groups in a society dominated by British Protestants, Irish Catholic temperance supporters wanted limited contact with French Catholic temperance activists. Various factors contributed to the lack of sustained cooperation between Irish and French Catholics, such as the linguistic divide, rivalry for control of the Catholic hierarchy in Canada, and increased anxieties among French Canadian leaders regarding the linguistic assimilationist policies of British colonists. More germane to this

33 Souvenir of the Golden Jubilee of St Patrick's T.A. \& B. Society, (Dominion Illustrated Company: Montreal, 1890), 9.

34 Montreal Daily Star, 11 August 1894, p. 8. 
chapter is the emphasis that the Canadian Irish Catholic clerical leaders placed on Catholic values and Irish nationality in their formulation of temperance, and the explicit links made between temperance and Irish Catholic ethno-religious identity. Thus in the French Catholic city of Montreal there were two Catholic temperance societies established in the early 1840s: an Irish one in 1840 and a French one in $1841 .^{35}$ It appears that the Irish Catholic laity participated in the project to create an Irish Catholic cultural world, without involvement from non-Irish Catholic groups.

Even during moments of apparent unity, French and Irish rivalry within Catholicism meant that both sides were well aware of the ethnic differences separating them. For instance, a correspondence was printed in the 6 September 1850 edition of The True Witness between John Hayes, president of The Catholic Total Abstinence Society of Toronto, and Chiniquy on the occasion of Chiniquy's visit to Toronto. Hayes, writing on behalf of the managing committee of the society, welcomed Chiniquy to the city and congratulated him on his success in extending temperance throughout Quebec. ${ }^{36}$ Hayes went on to note that Chinquy was well aware of the obstacles to the temperance cause in Canada, and because of that Hayes and the committee valued Chiniquy's work and success in the temperance cause all the more. In his response to Hayes's letter, Chiniquy noted the gratitude with which he received the well-wishes of the committee and spoke of the merits of temperance as an act of social regeneration. ${ }^{37}$

Though Hayes did acknowledge on a general level the work of Catholic temperance undertaken by Chiniquy, he nonetheless told Chiniquy that his work was initiated specifically toward the improved social position of "your people," along with "their

\footnotetext{
Ibid., 23.

True Witness and Catholic Chronicle, (Montreal), 6 September 1850, p. 6, col. 1-2.

37 Ibid.
} 
happiness" in the life to come ${ }^{38}$ Hayes thus distinguished between Chiniquy's "people" and himself (and presumably the rest of the committee for whom he was speaking) as an Irish Catholic. For his part, Chiniquy also distinguished his temperance work from the temperance work of his Irish co-religionists, noting that his work was directed specifically at Catholics of French origin who inhabit Canada East (Quebec), while lauding Hayes and the Toronto society for continuing and furthering the temperance work done by and for Irish Catholics. ${ }^{39}$ Thus, both Hayes and Chiniquy recognized that their temperance work was undertaken on behalf of their respective, and distinct, ethno-religious communities.

The Canadian Irish Catholic temperance movement and its advocates aided in the growth of the Catholic culture distinct from mainstream Protestantism and an Irish Catholic culture distinct from French Catholicism. Because Irish Catholic clerics used temperance societies as a means to establish a distinct Irish Catholic culture under their control, they understood that their movement could not be led by French Catholic temperance advocates such as Chiniquy. The language issue made the struggle more complex, dividing as it did the Church into French-speaking and English-speaking parts. Considering the demographics of Canada at this juncture, the narrowing of temperance along ethnic lines led to temperance becoming an Irish-specific issue among English-speaking Catholics.

\section{Moral Suasion Versus The Power of the State}

Brian Clarke has explored the Irish Catholic temperance movement in Toronto and identified the sacramentalization of the movement. Yet, he does not delve too deeply into the theological grounds behind this approach. Building on Clarke's work, this section will outline the important role that theology played in shaping the contours of Catholic

38 Ibid.

39 Ibid. 
temperance. The prominent place of clerics within the Irish Catholic temperance movement reflected the importance of Catholic beliefs and practices in these associations. The rules of Phelan's society in Montreal stated that when new members first took the temperance pledge they were to do so kneeling before the altar in the presence of the president of the society, the priest, or an assistant priest, who would then give them a blessing. ${ }^{40}$ Every member was obliged to go to confession prior to taking the pledge "in order to rectify his conscience and to be guided by his pastor." ${ }^{41}$ Members were also required to say the daily prayer prescribed on the temperance medal. ${ }^{42}$ The rules and by-laws of the Father Mathew Association of Saint John, New Brunswick asserted that the chaplain, who was to be a member of the clergy appointed by the bishop of the diocese, would be the head of the society above the elected officers. ${ }^{43}$ Religious duties, such as taking the sacraments of penance and blessed Eucharist at least twice a year, accompanied membership, and most Irish Catholic temperance societies held their regular meetings on Sundays following Vespers. ${ }^{44}$

Catholicism and clerical control led to the Catholic temperance movement's rejection of legislative prohibition of alcohol in favour of a moral suasion approach, but one rooted in Catholic doctrine that resisted the mainstream temperance movement's shift to the state to curb alcohol consumption. Since the inception of the broader temperance movement in the 1790s, supporters had campaigned on moral suasion principles, which meant the diffusion of arguments that urged individuals to cease their production and consumption of ardent spirits and to reduce, but not necessarily eliminate, their intake of wine, beer, and ciders. But from

40 ACAM, 790.021, Temperance, 1842-3. Abridged Rules of the R.C. Temperance Association at the Recollet Church.

41 Ibid.

42 Ibid.

43 "Constitution and Rules of the Father Mathew Association organized at St. John, New Brunswick, 9 March 1871,” Toronto Reference Library, CIHM 98690.

44 Ibid. 
the mid-nineteenth century large swaths of the mainstream Protestant movement shifted from support for moral suasion to support for legislated suppression of alcohol production and consumption. ${ }^{45}$

Irish Catholic temperance advocates did support the right of the state to legislate on the alcohol question to a certain degree. For instance, during the debate over the Maine Liquor Law of 1851, which was a state-wide ban on liquor production and sales, a sentiment of support for legislative prohibition of alcohol was expressed in a letter printed in the Ottawa Tribune, the Irish Catholic paper in Ottawa, in April 1858. The writer argued that owing to the harm inflicted upon society by alcohol consumption; it was the duty of any government to denounce the production, importation and sale of alcohol severely and suppress them by means of needful penalties and punishments. ${ }^{46}$ This sentiment was shared by John Gough, the secretary of the St Patrick's Temperance Society in Bedford, Quebec. Born in the Irish county of Cavan in 1819, Gough came to the town of Bedford in 1837 and opened a harness-shop. Successful in this business, Gough was also involved in the volunteer militia for many years until he resigned in 1855 to take a clerkship in the commissioners' court. Gough was elected mayor of the township of Stanbridge in 1868 and was made a justice of the peace in $1870 .{ }^{47} \mathrm{~A}$ devout and active Catholic, Gough married his support for temperance with his Catholicism and Irishness, and also held positions of government under the liberal state. Gough felt that the established law was insufficient to battle booze, in part because the low cost of intoxicating drinks meant that people would continue to consume alcohol in large quantities. Gough urged "friends of the cause" to bring

${ }^{45}$ Quinn, Father Mathew's Crusade, 188.

46 Ottawa Tribune (Ottawa), 24 April 1858, p. 2, col. 3.

47 The Canadian Biographical Dictionary and Portrait Gallery of Eminent and Self-Made Men, Quebec and Maritime Provinces Volume, (American Biographical Publishing Company: Chicago, New York, and Toronto, 1881), 355-56. 
the matter before the legislative body to implement heavier duties on the distilling of whiskey and a law stating that no distiller be allowed to sell less than five gallons per customer. ${ }^{48}$ In addition, Gough recommended that all temperance societies form committees of vigilance in each parish or township for the purpose of "making compliant any person or persons found in a state of intoxication, exposed to public view." ${ }^{\prime 49}$ Likewise an 1854 pastoral letter signed by the bishops of Quebec, Montreal, Toronto, and Bytown thundered against those who evaded liquor laws and purchased illicit booze. "The flagrant violation of a law framed to protect public order and morality demands the most vigorous repression," the letter read, and went on to exclaim that people who do evade this law "are unworthy of being admitted to the sacraments of the church." 50

Such examples notwithstanding, support for the complete legal prohibition of alcohol and the liquor trade seldom emanated from Irish Catholic temperance circles. Irish Catholic temperance leaders more typically argued against prohibition, instead promoting the value of moral suasion. Brian Clarke has argued that the clergy were themselves disturbed by the social behaviour and drinking habits of Irish Catholic immigrants. Armand de Charbonnel, Archbishop of Toronto from 1847 to 1860 , asserted that drunkenness was far too common among the Irish and he was sure that this was the cause of their religious indifference. The moral reform of the laity, Charbonnel believed, was essential to effect their spiritual renewal. ${ }^{51}$ In this distinct Catholic view of temperance, "sacramentalized temperance" as Brian Clarke deemed it, the focus was on "individual moral reform and spiritual regeneration

48 Ottawa Tribune (Ottawa), 24 April 1858, p. 2, col. 3.

49 Ibid.

50 Ottawa Tribune (Ottawa), 23 July 1854, p. 4, col. 3.

51 Brian Clarke, "The Parish and the Hearth: Women's Confraternities and the Devotional Revolution Among the Irish Catholic's of Toronto, 1850-1895," in Creed and Culture: The Place of English-Speaking Catholics in Canadian Society, 1750-1930, ed. Terrence Murphy and Gerald Stortz (Montreal and Kingston: McGill-Queen's University Press, 1993), 188. 
rather than on reform of the social order through prohibition." Catholic temperance societies were established to save souls not pass legislation. ${ }^{52}$ Thus, Catholic opposition to the legislated prohibition the Protestant temperance movement was advocating by the middle of the nineteenth century lay in the belief that temporal laws were inefficient to combat excessive alcohol consumption. Man-made laws, it was felt, were not enough to reform the behaviour of individuals. Legislation was desirable, but for a real change to occur it was necessary to look to Catholic theology. The Ottawa Tribune's position on temperance reflected the hybridity of moral suasion and legislative techniques, with moral suasion termed more effective. The Tribune called for heavy penalties to be given to those who commit crimes while intoxicated and that tavern licences be regulated with strictness, yet also believed there was "more virtue in good example, in generous self-denial, in gentle precept, than in restrictive legislation." 53

The True Witness argued that a "golden age" of temperance would be brought about only through the moral reformation of individuals. Diminish the number of alcohol consumers, it argued, "and the sellers will soon be driven out of the field." ${ }^{, 54}$ This logic was furthered by the True Witness when it commented on the 1865 Annual Report of the Montreal Chief of Police. This report showed that whereas in 1864 in Montreal 290 licensed establishments existed there were 250 unlicensed ones. In these two years there had been a decrease in unlicensed drinking establishments by thirty-five and an increase in licensed drinking establishments by thirty-six, with the total changing only by one from 540 to $541 .{ }^{55}$ This, according to the True Witness, was proof that licensed and unlicensed grog-shops stood in inverse ratio to one another: as one category diminished the other increased in the same

52 Clarke, Piety and Nationalism, 132-3.

53 Ottawa Tribune (Ottawa), 3 August 1854, p. 3, col. 1.

54 True Witness and Catholic Chronicle, (Montreal), 23 May 1851, p. 4, col. 3.

55 True Witness and Catholic Chronicle, (Montreal), 6 April 1866, p. 5, col. 1. 
quantity. Having fewer unlicensed grog shops only served to increase the number of licensed liquor sellers, because the craving or demand for alcohol amongst the population remained the same. Legislative prohibition, according to this line of thought, did not bring about the moral reformation of the population necessary to rid society of drunkenness. Moral reformation, not laws, was necessary to suppress drunkenness, and this, according to the Irish Catholic clergy, could only come about through the intervention of the Catholic Church. Archbishop Lynch expressed this sentiment in an 1884 letter, in which he discussed the Canada Temperance Act of 1878, a piece of legislation that extended nationally the local option of the 1864 Dunkin Act. Declaring his support for the cause of temperance, Lynch nonetheless maintained his belief that changing laws would have little impact if the behaviour of individuals did not change. If the people themselves don't want to stop drinking, he wrote, "prohibition won't do it, they will get it somehow."56 The True Witness concluded that while the state should treat the liquor traffic as any other traffic from which it had the right to raise revenue and over which it exercised fiscal or police control, the spiritual reformation of the individual which would bring about a temperate society would be achieved by Catholicism rather than legislation. In presenting this analysis, Irish Catholic clergy aimed to integrate the temperance question into Catholic practice, and limit interference in their Catholic direction of temperance. ${ }^{57}$

\section{$\underline{\text { Protestant and Catholic Temperance: Two Solitudes }}$}

Despite sharing the fundamental goal of creating a temperate society, divisions over how to best achieve that goal meant that there was little cooperation between Irish Catholic and

56 ARCAT, Archbishop Lynch Fonds, AH 2940, Letter from Archbishop John Joseph Lynch, 1884.

57 True Witness and Catholic Chronicle, (Montreal), 6 October 1854, p. 4, cols. 1-3. 
Protestant temperance societies. Theological differences between the Catholics and Protestants resulted in contrasting perspectives on temperance. While they argued for some control over the production and consumption of alcohol, Catholic temperance advocates refused to denounce alcohol in and of itself as evil. Catholic opposition to prohibition was justified through scripture and theology. The True Witness argued that for Catholics alcohol itself never became something inherently evil that had to be completely banned. In an editorial they cited the story of Jesus accepting wine on the cross and argued that this was evidence that Christianity sanctioned alcohol; thus to denounce the mere use of alcoholic beverages was a "most blasphemous and damnable heresy." 58 As Clarke notes, the moderate use of alcohol, as of all things created by God, had long been accepted by the Catholic Church. ${ }^{59}$

Theological differences were at the heart of a quarrel between the True Witness and the Canada Temperance Advocate in the 1850s. The Canada Temperance Advocate was a temperance journal that began publishing out of Montreal in 1835 . Widely circulated, by the 1840 s it claimed to have a readership of over 30,000 in Upper and Lower Canada. ${ }^{60}$ The Advocate represented the mainstream Protestant temperance movement, and its long-time editor, John Dougall, has been called the Canadian prophet of temperance by historian Jan Noel, who argued that Dougall "translated temperance enthusiasm into a social blueprint that won wide acceptance in mid-nineteenth-century Canada." ${ }^{91}$ Dougall was a Presbyterian but left that Church in 1840 because it "worshipped rumsellers" and joined the Congregational Zion Church. ${ }^{62}$ As an evangelical Protestant, Dougall used the Advocate, along with his other

58 Ibid.

59 Clarke, Piety and Nationalism, 132.

60 Craig Heron, Booze: A Distilled History, (Toronto: Between the Lines, 2003), 53.

61 Jan Noel, Canada Dry: Temperance Crusades before Confederation, (Toronto and Buffalo: University of Toronto Press, 1995), 77.

62 Joanna Dean, Religious Experience and the New Woman: The Life of Lily Dougall (Bloomington: Indiana 
newspaper, the Montreal Witness, to encourage the evangelical ideal of temperance. ${ }^{63}$ Dougall's Protestantism made him an easy target for the Irish Catholic press, as the naming of the Irish Catholic organ as the True Witness in contrast to Dougall's Witness, suggests. Ethnic and theological differences between Dougall and the Irish Catholic community resulted in a divergence in perspectives on temperance, despite a shared support of the temperance cause. Dougall supported the Maine Liquor Law of 1851, and laudatory columns were devoted to this piece of legislation in the pages of Dougall's Advocate. This resulted in a critique of Protestant temperance societies from the True Witness, which opposed the legislation. Moreover, the True Witness argued that because it was a Catholic newspaper and the Canada Temperance Advocate was Protestant, the two had "nothing in common to which they can alike appeal." ${ }^{64}$ In response, the Canada Temperance Advocate questioned why Catholics and non-Catholics had no principles in common. To this query, the True Witness thundered that the first principle of every Catholic is that in all problems involving "faith and morals the Catholic Church is the sole authority given by God to man." ${ }^{65}$ Because this ultramontanist reasoning was denied by non-Catholics, the True Witness argued, "Catholics and non-Catholics have no principles in common."

Strictly speaking this was untrue. Given their shared goal of creating a temperate population, Catholic and Protestant temperance proponents alike opposed frequenting locations where liquor was sold, and ritualized drinking practices such as treating. Treating was a common drinking custom in the nineteenth century, which Craig Heron notes was widespread and deemed essential for business, cementing relationships between drinkers,

63 Ibid.

University Press, 2006), 18.

64 True Witness and Catholic Chronicle, (Montreal), 15 October 1852, p. 4, col. 2.

65 True Witness and Catholic Chronicle, (Montreal), 10 December 1852, p. 4, col. 3.

66 Ibid. 
and overall conviviality. ${ }^{67}$ Because of the general pervasiveness of treating, it was a target of the mainstream temperance movement. Like the mainstream temperance movement, Catholic temperance societies such as Phelan's had rules forbidding members from participating in the ritual of treating. However, because Catholics, unlike Protestants, did not view alcohol as inherently evil, such injunctions came with qualifications. While the rules forbade members from taking or giving treats in taverns or public houses, at raffles or public assemblies, an exception was made for treating when it was an "absolute necessity, such as in the case of excessive cold or heat, or sickness." ${ }^{\prime 68}$ And though it was stated that members were to avoid frequenting places where ardent spirits were sold, this could be overlooked in the case of travellers "who are sometimes obliged to take some refreshments in taverns." 69

Thus while the issues of treating and presence in places where ardent spirits were sold were commonly seen by both Protestant and Catholic temperance societies as dangerous to their cause, theological divisions between the two camps that led to divergent temperance views was manifest in Catholic opposition to prohibition. Irish Catholic temperance leaders were adamant that liquor laws and legislative enactments could never replace the sacraments and Grace of God. They believed that Christ established His Church as the remedy for all the moral evils that have their origin in the corrupt heart of man and drunkenness was certainly one of these moral evils. If the Church, therefore, was the remedy for all moral diseases, then it was fully competent to cure society of drunkenness and intemperance. A position of clerical authority over the lives of the Catholic population was staked out by Pope Pius IX, culminating in the First Vatican Council's dogmatic definition of papal infallibility. This position was also laid out in Pius' 1874 encyclical on the Church in Austria, in which he

67 Heron, Booze, 35.

68 Ibid.

69 ACAM, 790.021, Temperance, 1842-3. Abridged Rules of the R.C. Temperance Association at the Recollet Church. 
asserted that the Austro-Hungarian Empire's proposal of certain laws intended to subjugate the Catholic Church to the civil authority. "This," Pius stated, "is, of course, against the ordination of Our Lord Jesus Christ." In denying the state a moral or spiritual jurisdiction, Irish Catholic temperance advocates also opposed temperance societies that supported prohibition. They railed against "any man made society and organization that gave itself the functions of the Church of Christ and professed to do by its rules and regulations, by its pledges and human devices what the blessed Sacraments are unable to effect and the assertion that in making His Church Christ did His work imperfectly and it requires supplementing by human agency."70 The True Witness argued that only the "Grace of God" could combat drunkenness, and this remedy was applicable only to Catholics and was of no use to Protestants. To their disgrace, the editorial asserted, Protestant countries alone "confess the impotence of moral and religious influences to reform the drunkard and thus clamour for legislative enactments," while in Catholic countries "such tyrannical measures are never dreamt of and would not be tolerated for one moment."71 The True Witness cast the Church as both champion and moral guide of the self-governing individual, and the liberal state as the tyrannical oppressor.

The effect of theological differences between Irish Catholic and Protestant temperance societies were divergent views regarding the optimal outcomes of temperance. Clerical Irish Catholic temperance leaders argued that Protestant temperance was too involved in total prohibition, worldly affairs and government legislation. Irish Catholic temperance advocates insisted that the Catholic movement was more spiritually oriented:

Catholicity denounces drunkenness because it drags down to hell and excludes forever from Heaven-Protestantism because it entails poverty and is ruinous to

70 True Witness and Catholic Chronicle, (Montreal), 17 September 1852, p. 4, col. 3.

71 True Witness and Catholic Chronicle,, (Montreal), 27 April 1855, p. 4, cols. 3-4. 
thrift and worldly prosperity; Catholicity preaches temperance as a Christian dutyProtestantism as a civic virtue...one seeks to reform mankind by spiritual means, spiritual threats, and the hope of spiritual rewards-the other by secular means, by contrasting the poverty, filth and misery of the drunkard with the wealth, thrift, and general comfort of the sober man. ${ }^{72}$

The True Witness was arguing that Catholic temperance societies sought to "bring about moral reformation by the use of spiritual means," while Protestant temperance societies were formed outside of the Church and attempted to effect a moral reformation without religion but for reasons of self-advancement rather than out of morality and Christian duty. ${ }^{73}$ Irish Catholic temperance advocates fought against the social problem of excessive consumption of alcohol, but their utilization of temperance as a means for Catholic community building and their fealty to Catholic faith and spirituality led them to establish a distinctly Catholic temperance movement separate from Protestant temperance. Catholic beliefs formed the basis for the moral suasion approach of Irish Catholic temperance societies.

The temperance movement was not the only area in which clergy sought control and denied the state jurisdiction. As in the field of education, the True Witness opposed the establishment of Houses of Industry because of the control that state or civil authority would have over their operations. As Catholics, it was argued, they objected to any charitable or religious institution controlled by secular authorities, or any such institution over which the Catholic Church did not have supreme control. Like arguments opposing state-sanctioned prohibition, they argued that because Christianity is the sole remedy for the moral diseases which afflict mankind, the sole agent to be relied upon for the moral reformation of the "social outcasts destined to be the subjects of the House of Industry" would be a sound religious education. ${ }^{74}$ Such reasoning was expressed by the laity as well. The Harp, an Irish

72 Ibid.

3 Ibid.

74 True Witness and Catholic Chronicle, (Montreal), 13 June 1851, p. 4, cols. 1-2. 
Catholic journal established in Montreal in 1874 by printer Felix Callahan, even questioned the necessity of having organizations dedicated to temperance if those organizations did not have Catholic practices at their core. In an essay on the question of intemperance they positioned drunkenness and intemperance within a constellation of sins, arguing that "the disease or sin of intemperance is similar to any other carnal sin" such as impurity. Both, The Harp argued, have their root in the fallen nature of man, both attacked the peace of the family, and both undermined society. The best way to deal with these linked social problems was not through legal prohibition of certain activities aimed at shaping individual behaviour, nor was the optimal approach to intemperance the mere forming of temperance societies and taking the pledge. Rather, it argued, the best way to deal with intemperance and the constellation of sins linked to it was through the sacraments of the Catholic Church:

How do we arrest the progress of impurity, and banish it from the system? By enacting and enforcing in the courts prohibitory laws? No! By forming societies whose individual members are pledged to abstain from impurity in thought, word, and deed? No! By the confessional; by the sacrament of the Blessed Eucharist; by prayer. These remedies, and these only, can subdue the passions, and restore health to the soul. Ten thousand prohibitory liquor laws, all rigidly enforced, will never destroy an appetite for liquor, and therefor will never banish the disease of intemperance. Total abstinence societies and the "pledge" are useless without frequent confession, communion, and prayer. To fight and conquer evil, no matter under what form, we need not become members of this society or that union, if we are faithful members of that most perfect union, the Catholic Church, if we obey her in all things, and frequently approach her altars. We know that Total Abstinence societies, when and where properly established, have the approval of the clergy and we do not wish to disparage them. We do not, however, believe, for reasons above stated, that they are at all necessary...The more we reflect on intemperance and its effects, and the closer we watch the working of Total Abstinence societies, and Protestant Associations of Good Templars or Sons of Temperance, the stronger grows our belief in prayer and the sacraments as the only remedy for a most mischievous vice. ${ }^{75}$

The issue as stake in this debate was the Catholic hierarchy not wanting to cede control of moral issues to external forces. The Harp believed the state had the right to govern and

75 The Harp (Montreal), November 1874, p. 210, col. 2-p. 211, col. 1. 
regulate the liquor traffic as it would any other sector of the economy, such as setting tariffs and taxes, but that Protestant temperance advocates were employing the state to enact measures that should rightly be under the jurisdiction of God. The Irish Catholic community believed the temperance movement should be focused on the moral reformation of the individual, and this reformation could only come about through the Grace of God. The temperance societies organized within the Catholic community were thus formed on Catholic principles and fused temperance and Catholicism. In doing this, the clergy created a means to maintain a separate culture that would not be subsumed or put under control of the dominant Protestant culture of the British colonies in North America.

\section{National and Global Catholic Temperance Organizations}

Mainstream temperance and total abstinence societies increasingly looked to the state to enact and enforce liquor laws. Ferry argues that the 1870 s was a period in which temperance unions were established to lobby more effectively for prohibitory legislation. ${ }^{76}$ And while Catholic temperance societies also began to organize nationally with organizations such as the League of the Cross and Catholic Total Abstinence Union of America, these organizations continued to resist state enforcement of strict liquor laws and prohibition. National and international Catholic temperance organizations remained anchored in local parish and diocesan associations and continued to preach a moral suasion doctrine in which the Catholic hierarchy, rather than the state, had jurisdiction.

At the Second Plenary Council of Baltimore of 1866, which was the second of three national meetings of Catholic bishops in the United States, American bishops put forth a

76 Ferry, Uniting in Measures of Common Good, 115, Cheryl Krasnick Walsh, "Dominion Alliance for the Total Suppression of the Liquor Traffic," in Alcohol and Drugs in North America: A Historical Encyclopedia, Vol. 1, eds. David M. Fahey and Jon S. Miller, (Santa Barbara, California: ABC-CLIO, 2013), 228. 
strong endorsement of teetotalism. They wrote that the most frightful scandals came about due to excess in drinking, and praised "the zeal of those most faithful children of the Church," who "pledge themselves to Total Abstinence." 77 John Quinn argues that this injunction led to a revival amongst Catholic temperance societies, as new associations were organized and older organizations were revitalized. ${ }^{78}$ Efforts were then made to unite parish temperance societies into broader organizations. ${ }^{79}$ Thus, with a new zeal, and seeking a more unified and consolidated system of Catholic temperance, the Catholic Total Abstinence Union was formed in Baltimore on 22 February 1872. The movement for a national body of Catholic temperance societies was also realized in England with the formation of the League of the Cross under the leadership of Archbishop of Westminster, and future Cardinal, Henry Edward Manning in London in 1873.

According to a CTAU pamphlet published in 1881, the success of the organization resulted from its foundations on a "thoroughly Catholic basis." ${ }^{\prime \prime 0}$ This affirms the theological dimensions of the Catholic temperance movement and the widely-held view that temperance was a religious, rather than a temporal, matter. Even the Irish Canadian, a press organ whose own devotion to Catholic leadership was often called into question, asserted that though there were some excellent lay workers in the cause of temperance in Toronto, "whose highest ambition is to see their fellow-citizens rescued from a life of poverty and wretchedness," they had done "comparatively little" in efforts at reforming the drunkard. ${ }^{81}$ So little, the Irish Canadian insisted, that "the mission of our Temperance Societies had been next to a failure." 82 The solution was increased participation of the clergy in the Catholic

77 Quinn, Father Mathew's Crusade, 180

78 Ibid.

79 Ibid., 181.

80 Ibid.

${ }^{81}$ Irish Canadian (Toronto), 27 October 1875, p. 4, cols. 3-4.

82 Ibid. 
temperance causes. "We see no hope for improvement," the editorial maintained,

except prompt and vigorous action on the part of the clergy. Our venerated Archbishop, on every occasion of Confirmation, makes it a rule to administer the temperance pledge to the boys and girls confirmed to be strictly observed till they are a certain age. If brought under his Grace's notice we are confident the temperance societies would also be well cared for, that under his fostering care a new energy would be infused into their movements; that the words of exhortation would fall on willing ears; and that recruits would swell the temperance ranks from all quarters in obedience to the call of their pastors. With the bishops and clergy on their side, the success of the Catholic temperance societies is assured; lacking this support, at best they will but drag out a precarious existence. ${ }^{83}$

Irish Canadian editor Patrick's Boyle's support for increased clerical control over temperance seems inconsistent with his usual editorial stance in which Irish nationalism, rather than clericalism, was privileged. ${ }^{84}$ Boyle argued for more clerical involvement on the grounds that the groups are failing in their moral reform efforts without them. This position suggests the widely-held Catholic view that temperance, unlike Canadian or Irish politics, was a religious, rather than a temporal or political matter and as such the clergy should take the lead in temperance affairs. In seeking clerical leadership in temperance, Boyle looked to the example of the CTAU as a desirable organizational model. The structure of the American societies was laid out in the pages of the newspaper, and it was remarked that CTAU branches are established and operated under various names, and had local jurisdiction to write and enforce their own by-laws and constitutions. However, it continued,

in order to obtain harmony and concerted action among the whole, on important occasions, and the better to consolidate and perpetuate existing interests, it was deemed prudent to gather the different temperance organizations into one fold... and govern them with an executive council, whose special duty it would be to cultivate a closer acquaintance, to foster a more liberal and charitable sentiment, and a more frequent interchange of opinion among men having the

83 Ibid.

84 Boyle's position on the Catholic Church and Irish Canadian affairs will be discussed further in later chapters. 
same object in common. ${ }^{85}$

The plan was adopted in the United States, observed the editorial, and the result had been the spreading of the temperance cause across the country. Based on this success, the general desire for similar temperance unions had spread to Canada and a meeting of Catholic temperance societies from across Ontario was desired.

The CTAU was a parish-based organization. It acted as an umbrella association made up of local Catholic temperance societies, which retained control and influence in the movement. For instance, the St Bridget's Total Abstinence and Benefit Society of Montreal was affiliated with the CTAU. ${ }^{86}$ In order to join the CTAU, a local temperance society first had to ask permission of the parish pastor. If granted, a letter signed by the local affiliate's president would be sent to the general secretary of the CTAU along with a certificate signed by the pastor of the parish stating that the organization has received pastoral recognition. No local society would be enrolled under the larger umbrella of the CTAU without the consent of the spiritual director of the local society. Once enrolled, the constitution and by-laws of the CTAU had to receive approval of the pastor of the parish. The constitution and by-laws were strict in their allegiance to Catholic values, and to the CTAU itself. They asserted that no person would be admitted as a member who was not a Catholic. ${ }^{87}$ There was also a mutual benefit society component to the CTAU, and it was stated no person would be admitted as a beneficial member-meaning a member who receives benefits from the society - who was a beneficial member of another total abstinence society. To verify this, upon application for individual membership, the president of the society was to ask the

85 Irish Canadian (Toronto), 21 October 1874, p. 4, col. 1.

86 Lovell's Montreal Directory for 1880-81, (Montreal: John Lovell \& Son, 1881), 783.

87 These particular rules came from the Archdiocese of Philadelphia, which was one of the largest and most active dioceses connected with the CTAU. 
prospective member publicly in front of the society if they were a Catholic or a beneficial member of another total abstinence society. In addition, the potential member would be asked if he belonged to any society condemned by the Church. ${ }^{88}$ While such rules were implemented to allow for the growth and eventual hegemony of a centralized Catholic temperance society under the direction of the Catholic hierarchy, the parish temperance society remained powerful within this structure.

The CTAU advocated moral suasion over state enforced prohibition. In a history of the movement written in 1907, Joseph C. Gibbs laid out the philosophy of the society, which lauded "the principle of individual subjugation to a moral rule" and stated that only by such subjugation can the "modification of habit and instinct take place which constitutes the advancement of character in the direction of a state of social harmony and general happiness." ${ }^{89}$ In his opening remarks at the first convention of the CTAU, named the National Temperance Convention and held in Baltimore on 22-23 February 1872, Rev. James McDevitt of the District of Columbia asserted that the organization must "work on a strictly Catholic basis" and "labor for the amelioration of the victims of intemperance through religious principles only." ${ }^{90}$ The CTAU thus staked out a clear position on the issue of moral reformation in their temperance crusade. However, their views on alcohol legislation were more ambiguous. In the resolutions passed by the CTAU during its first convention, it was declared that the association did not deem it expedient to take part in any political or legislative agitation, in reference to the prohibitory liquor laws. In "An Address to the Catholics of America" issued during the 1872 convention, it was clearly stated that the

88 ACAM, 790.027, 1881-1913, The Catholic Total Abstinence Union of America/Canada Papers

${ }^{89}$ Gibbs, History of the Catholic Total Abstinence Movement of America, (Philadelphia, 1907), 7.

90 Ibid., 16. Though it might seem confusing that an organization that called itself a total abstinence society would call its convention a temperance convention, the terms temperance and total abstinence were used interchangeably throughout the period. On this point see Brian Clarke, Piety and Nationalism, 303, fn. 34. 
motto of the organization was moral suasion. "With prohibitory laws, restrictive license systems, and special legislation, we have nothing whatever to do," the address read. ${ }^{91}$ At the same time, however, it was resolved that the CTAU recognized that "great good that would accrue from the suppression of public drinking-places, and from such legislation as would restrain the manufacture of intoxicating liquors within bounds consistent with public morality and will gladly hail such legislation whenever the proper authorities may grant it." 92 They believed that the laws of the state should be followed and enforced, but believed suasion more efficacious in effecting real social change. Indeed, the convention adopted a decree from the 1866 Second Plenary Council of Baltimore that privileged individual moral reform through Catholicism over state prohibition. The decree, which was on the issue of temperance, asserted that, "by prayer, the frequent reception of the sacraments, and other works of piety, (Catholic temperance supporters) would obtain for themselves the Divine assistance, not putting their trust in their own resolutions or their own strength, but in God, without whom human efforts can avail nothing." The local diocesan associations likewise promoted the moral suasion temperance strategy. In 1875, the Catholic Total Abstinence Union of Connecticut passed a resolution favoring the principle of moral suasion as the most effective. ${ }^{93}$ Thus, even with its broader organizational ambition, the CTAU supported the moral suasion strategy of temperance reform.

Members of the Catholic clergy in Canada soon began organizing analogous associations. In fact, at the first meeting of the CTAU of America, held in Baltimore on 22 and 23 February 1872, it was noted that the original name of the organization was to be the Catholic Total Abstinence Union of the United States, but as societies in Canada wanted to

Ibid, 20 .

Ibid., 18.

Gibbs, History of the Catholic Total Abstinence Union of America, 191. 
join, the word "America" was used. ${ }^{94}$ Recognizing the progress made by the CTAU to the cause of temperance in the United States, and wanting to strengthen a Catholic alternative to the mainstream Protestant temperance movement, the first Canadian CTAU was organized in New Brunswick in the summer of $1872 .{ }^{95}$ The first annual convention took place at St.

Malachi's Hall in Saint John 29 June 1872. Represented at this meeting was the St. Dunstan Temperance Society of Fredericton, and the St. Malachi's Catholic Total Abstinence Relief Society and the Father Mathew Association, both of which were located in Saint John. John O'Brien, President of the Father Mathew Association, was elected president of the association. ${ }^{96}$

The New Brunswick association's constitution began with the notice of approval from Bishop Sweeny of Saint John, who noted that the Catholic hierarchy of New Brunswick examined and approved of the constitution and by-laws. This broad-based organization was to consist of Catholic temperance societies established in New Brunswick that were "recognized by the Ecclesiastical authority." 97 The spiritual director of the organization was to be either the Bishop of Saint John, or a clergyman named by the Bishop. Unlike the other officers of the union, the spiritual director was not an elected position. Because the CTAU of New Brunswick was meant to be structured as a kind of umbrella organization for all Catholic temperance societies within the province, it was to be funded by local societies through an initiation fee of ten dollars for the first year, followed by an assessment of seven cents per member each subsequent year. Membership was transferable between local temperance societies connected with the CTAU, meaning that individuals who

94 Gibbs, History of the Catholic Total Abstinence Union of America, 19.

95 "Constitution of the Catholic Total Abstinence Union of New Brunswick, Together with the Proceedings of the First Annual Convention of the Union, Held at Saint John, N.B. June 29 and 30, 1872," (St. John: Geo. A. Knodell, 1872), Toronto Reference Library, CIHM 54596.

96 Ibid.

97 Ibid. 
had memberships in a temperance organization connected with the CTAU could be received into a CTAU branch in their new locality upon presenting a signed certificate from their old society.

Taking a cue from their co-religionists, the Catholics of Ontario sought to unite their societies likewise in 1874 . The idea was first proposed by temperance activist and Lasallian Brother Arnold, whose efforts in this enterprise were aided by the Father Mathew and St. Mary's Temperance Associations of Toronto. Arnold, a native of Tipperary, had established the LaSalle Institute, a Catholic school, in Toronto, and also formed a local temperance organization in 1871 . Though he would relocate to Montreal by the end of the $1870 \mathrm{~s}$, Brother Arnold was noted to have done "more than all other men to instil a patriotic spirit into the Irish element" in Toronto. The initial meeting of the Irish Catholic temperance society organized by Brother Arnold took place on 7 December 1871 where "some thirteen gentleman subscribed their names as members." The Irish Canadian urged greater participation in this endeavor, arguing that "the effort about being made for the abatement of an evil, every day becoming more and more chronic, deserves the encouragement of all who have the interests of their fellow beings at heart." ${ }^{98}$ By 1874, seeking greater engagement from the Catholic population, Arnold proposed the organization of an umbrella temperance organization. Circulars were sent out to the various organizations across the province, inviting them to send delegations to the provincial gathering and injunctions were presented throughout the pages of the Irish Catholic press calling for active participation in such organizational meetings.

The first annual meeting of the Catholic Total Abstinence Union of Ontario took place on 21 October 1874. The Irish Canadian heralded this meeting as the beginning of a

98 For this organization see Irish Canadian (Toronto), 13 December 1871, p. 4, col. 5. For Brother Arnold, see True Witness and Catholic Chronicle, (Montreal), 1 September 1880., p. 3, cols 2-3. 
new era in the temperance world. ${ }^{99}$ It brought together temperance societies from Toronto, Tyendinaga, Belleville, Oshawa, Ottawa, Stratford, and Cobourg, among other places. The delegates met in Toronto's La Salle Hall, and the meeting opened with a prayer and words of encouragement from Rev. F. P. Rooney. Father Michael Molloy of the Irish Catholic Temperance Society of Ottawa was appointed chairman of the convention. Illustrating the importance of not only Catholic theology, but also the importance of Catholic approval and support, one of the first motions passed by delegates was to send telegrams asking for the benediction of Archbishop Lynch, as well as the Bishops of Hamilton, London, Kingston, and Ottawa on "the labors of the convention." 100 As always with temperance societies, a major purpose of the convention was to increase membership. In this endeavour, the Catholic Total Abstinence Union of Ontario proclaimed itself "anxious to embrace all the Catholic temperance societies of the province." 101 It was quick to note that the local societies would not forfeit their autonomy to the central committee, but would instead enjoy "the fullest local freedom." $" 102$

Rev. Father Sullivan of the St. Patrick's Temperance Society of Thorold was elected president of the CTAU at the inaugural meeting. On the eve of the following year's convention, Sullivan wrote a letter that was circulated in the Irish Catholic press which lauded the effects of temperance societies and continued to stress the importance of the local components of the collective union. While stating the importance of a union of Catholic temperance societies, Sullivan also remarked on the "healthy tone" that a local temperance society gave to its community. ${ }^{103}$ Sullivan argued that a larger union was necessary owing to

99 Irish Canadian (Toronto), 28 October 1874, p. 4, cols. 3-4.

100 Ibid.

101 Ibid.

102 Ibid.

103 Irish Canadian (Toronto), 6 October 1875, p. 5, cols. 3-4 
"the fear of decay or relaxation in discipline" stemming from local, isolated, unaffiliated temperance societies. ${ }^{104} \mathrm{He}$ allowed that separate societies were "good and perhaps perfect in their own way," but maintained that they were exposed to dangers of various kinds and therefore "require the encouragement of larger bodies to sustain them."105

The second annual convention took place in October of 1875 at St. Patrick's Hall in Ottawa. ${ }^{106}$ The meeting was opened by the members forming in procession through Sussex, Rideau, Dalhousie, and St. Patrick streets to the Catholic cathedral, where high mass was performed by Rev. Foley, who was secretary to Ottawa Bishop Duhamel. Present were members of the Ottawa Irish Catholic temperance society, as well as delegates representing societies from Almonte, Toronto, Cobourg, Trenton, among other locations. Some of the members of the Ottawa society spoke, including Alderman John Heney, vice-president of the Ottawa society, who welcomed the delegates from across Ontario and said it was not only the cause of temperance that was promoted at this event, but also the relationship between Catholicism and temperance. The president of the CTAU of Ontario, Father Sullivan, noted that as he was addressing "an assembly of Catholic gentlemen" he "need hardly to say to you that the frequentation of the sacraments is necessary to enable us to overcome the frailties of human nature." 107 Because of this, Sullivan urged the assembled societies to be earnest in recommending sustained sacramental devotions be performed by its members. In recommending the extension of Catholic temperance activities among the youth of Ontario, Sullivan referred to the advice of the Holy Ghost, "to train up a child in the way he should go, and when he grows old he will not depart from it." ${ }^{108} \mathrm{He}$ thus recommended the

\footnotetext{
104 Ibid.

105 Ibid.

${ }^{106}$ Irish Canadian (Toronto), 27 October 1875, p. 4, cols. 3-4.

107 Ibid.

${ }^{108}$ Ibid.
} 
formation of Cadet societies into the CTAU, echoing the "advice from the Holy Ghost" that "if temperate habits are acquired in the morning of their days, an assurance is given that their sun of life will set, undimmed by the mephitic vapors of soul destroying drink."109

That Catholic practice and Catholic organization were central to the Irish Catholic temperance movement is further evidenced by the resolution passed at this meeting recommending that local unions be formed of all the societies in each diocese throughout the province, with each diocese then being represented by delegates to the annual meeting of the CTAU of Ontario. Sullivan remarked that this structural organization worked "upon much the same principle as that which the church was constituted, and would prove of infinite benefit to the temperance movement." $" 110$

The organization noted in an address to the Catholics of Ontario, the society "is founded on a Catholic basis, and has the indispensable approbation of the hierarchy and clergy of the province, and, we might say, the Catholic world." ${ }^{111}$ Further, this address to the Catholics of Ontario to join in societies associated with the CTAU of Ontario stressed, not only the temporal benefits of total abstinence, but also the "spiritual advantages which are to be derived from connection with our organization." 112 It was noted that all of the members were obliged by a provision in the constitution of the organization to approach the sacraments at certain periods. This injunction to participate in Catholic practices was deemed "an advantage which cannot be too highly prized, since we rely for success upon the grace of God communicated to us through the Sacraments of the Church."113

Even though the CTAU organized itself to send diocesan representatives to the

\footnotetext{
109 Ibid.

110 Ibid.

111 Ibid.

112 Ibid.

113 Ibid.
} 
provincial level, the Church had no parallel institution at that level except where dioceses or archdioceses coincided with provinces. As an initiative aimed partly at clerical control, structures that were comparable with ecclesiastical ones would have been easier to influence, and it appears that these differences led to attempts to reorganize at the archdiocesan level. For instance a temperance union was organized by Archbishop Lynch in Toronto in 1876. At its inaugural meeting in February 1876, delegates from fifteen temperance societies in the Archdiocese of Toronto were present, including representatives from Niagara Falls, Brock, Markham, Port Colborne, St Catharines, Port Dalhousie, Thorold, Father Mathew Temperance Association of Toronto, Father Mathew Association of Oshawa, Father Mathew Association of Dixie, and the Toronto St Patrick's Temperance Society. ${ }^{114}$ Similarly, the Irish Catholic Temperance Convention of Montreal, which met on 12 June 1884 in St Patrick's Presbytery, with father Patrick Dowd acting as president, sought to organize at the diocesan level. The purpose of this convention was to promote temperance by all legitimate means and act in the name and by the authority of the various societies in emergencies when prompt and united efforts are required to advance the cause of temperance. ${ }^{115}$ This movement was made up of representatives from St. Patrick's, St Ann's, St Gabriel's, and St Mary's parishes, and as its name suggests, was an overtly Irish and Catholic organization. ${ }^{116}$ Thus, even as Catholic temperance sought a more united front in the war on alcohol, they remained wedded to the values of moral suasion, grounded in the Catholic faith, and anchored in local parishes.

114 Irish Canadian (Toronto), 23 February 1876, p. 4.

115 Souvenir of the Golden Jubilee of St Patrick's TABS, 25-26.

116 Official Report of the Debates of the House of Commons of the Dominion of Canada. First Session-Sixth Parliament, Vol. XXIV, 13 May-23 June 1887, (MacLean, Roger, \& Co.: Ottawa, 1887), 857-58. 


\section{$\underline{\text { Conclusions }}$}

This chapter explored the moral and theological arguments of the clergy that were framed in opposition to legislative prohibition by the liberal state. The hierarchy believed that Catholics should abide by state laws but parted company with the mainstream or Protestant temperance movement over motivations, means, and methods. The clergy saw spiritual regeneration rather than material prosperity as the proper goal of temperance. Moral reform and spiritual regeneration could come only through modifying behaviour and not from banning access to alcohol, and individual transformation could not be achieved through selfhelp or human agency alone but only through the sacraments and the grace of God. The confessional, sacraments, and prayer were the path to sobriety. They did not believe alcohol itself to be inherently evil. Denying the state a moral or spiritual jurisdiction, and indeed a role in the education of Catholics, they opposed the force of organized religion to the intrusion of the liberal state into the everyday lives of Catholics. Catholic commentators even denounced legislative enactments prohibiting the production and sale of alcohol as "tyrannical measures" and constructed the Church as the moral guide of the self-governing individual.

Within this clerically-controlled temperance model, two distinct organizational phases were evident. The period from the 1840 s to the early to mid 1870 s was characterized by parish-level organizations. Irish Catholic clergy like Patrick Phelan organized temperance societies within an ultramontane Catholic culture. Catholic temperance thus had different motivations from the Protestant temperance societies explored by Darren Ferry. Establishing clerical control over temperance societies was part of the concerted international movement sketched in the previous chapter to put Irishmen in charge of dioceses by supporting the pretensions of the pope, to bring local parishes and associations under clerical control and 
Roman devotions, and separate Catholic daily life from mainstream Protestant or secular society. At the same time the desire of Irish congregations to secure Irish priests who would champion Irish causes provided the opportunity for ultramontane clergy to take control of parochial administration from the laity as the price of advancing Irish interests. Catholic beliefs and practices informed their views on temperance as a spiritual matter, rather than a temporal matter. This led to Catholic opposition to the prohibition of alcohol, in a marked difference to the view of their Protestant counterparts. Moreover, unlike Protestant temperance societies, women did not participate in Catholic temperance societies. Yet, gendered ideals were a major part of the dissemination of temperance among Catholics.

As mainstream temperance shifted toward calling on the state to enact prohibitory legislation in the 1870s, the gulf between Protestant and Catholic associations widened. Mainstream temperance associations organized nationally to push for prohibition and Catholics also created national, provincial, and diocesan temperance organizations that paralleled the hierarchical structures of the Church, to rescue local associations from isolation and centralize their administration while strengthening the control of the clergy. Yet, even as these national and international organizations were established, Catholic temperance societies did not look to the state to enforce liquor laws. Mainstream Protestant temperance unions that operated at the national level lobbied for state prohibition, while Catholic temperance societies shored up Church, rather than state, authority. Catholic opposition to state-enforced prohibition resisted the growth of the state as it sought to extend its reach into areas it had previously had lacked jurisdiction to control..

That clerical authority in matters such as temperance was accepted by laity did not preclude Irish ethnicity and middle-class values from emanating from Irish Catholic temperance societies, as Chapter Five shall demonstrate. From the inception of Phelan's 
organization, the Irish Catholic laity who made up the leadership and committees of these organizations, while content to belong to societies under Church direction, nonetheless had secular goals in mind for their support of temperance. They sought to present themselves as liberal self-regulating individuals. Indeed, as Brian Clarke argued, temperance "also appealed to the clergy's secular ambition to raise the social status of their flock" $" 117$ preaching "a dual message of religious uplift and social success." 118 The process of forming respectable class, ethnic, and gender identities undertaken by the Irish Catholic laity in temperance societies was a major part of this regenerative project and will be the focus of the following chapter.

117 Clarke, Piety and Nationalism, 137-38.

118 Ibid., 139. 
Chapter Four: Irish Catholic Lay Temperance: Membership, Leadership, Class, and Values

\section{$\underline{\text { Introduction }}$}

The ultramontane push in Catholicism that saw the establishment and expansion of Catholic institutions meant that the laity who were so disposed joined parish-based, Catholic temperance societies rather than become active in the wider temperance movement. The Catholic hierarchy's control of the Catholic temperance movement, resistance to state encroachment into the quotidian lives of Catholics, and anti-liberalism suggest the challenge that the Irish Catholic associational movement posed to the formation of a liberal British Canadian state. Yet ultramontane Catholic leadership in the temperance movement did not preclude the burgeoning Irish Catholic lay middle class from espousing liberal individualism and encouraging the lower orders to emulate middle-class respectability by belonging to a temperance society. Brian Clarke observed that while the clergy founded temperance societies for religious purposes, the aspirations to self-improvement and self-respect inherent in the temperance movement suited the goals of the striving Irish Catholic laity. ${ }^{1}$ Indeed, the clergy wanted to use temperance as a means to organize the Irish Catholic community under their spiritual control in rejection of nascent state control, whereas middle-class Irish Catholics saw temperance as a way of integrating and advancing in Canadian society on thoroughly middle-class terms that embraced respectable sobriety, political loyalty, and period gender norms. ${ }^{2}$ Yet there was overlap between religious and secular objectives. According to Clarke, the clergy also had ambitions to raise the social position of

1 Brian Clarke, Piety and Nationalism: Lay Voluntary Associations and the Creation of an Irish-Catholic Community in Toronto, 1850-1895, (Montreal and Kingston: McGill-Queen's University Press, 1993), 137, 139.

2 A similar point is made by Deidre Moloney, but she argued that the last two decades of the nineteenth century saw the growth of a Catholic middle class and an increase in lay activity. Clarke, and this study, would argue that there existed significant lay activity in Canada well previous to the 1880s. Deidre Moloney, American Catholic Lay Groups and Transatlantic Social Reform in the Progressive Era, (Chapel Hill and London: University of North Carolina Press, 2002), 7. 
parishioners, meaning that temperance created a twin message of "religious uplift and social success. ${ }^{\prime 3}$ But for the clergy the primary motivations for espousing temperance were religious, for the laity often secular. The middle-class community's articulation of temperance objectives reflected the maturation and growing strength of an Irish Catholic middle class in Canada whose orientation was increasingly toward success and acceptance in the wider society.

Victor Walsh has laid out the duality of the scholarship on nineteenth-century temperance which pits, on one side, middle-class Protestant reformers attacking urban vices such as the saloon and, on the other side, immigrant working-class life which was typically the object of censure by Protestant reformers. ${ }^{4}$ Walsh points out that this dichotomy neglects the large Irish Catholic middle-class temperance crusade in which Irish Catholic immigrants were the middle-class reformers as well as the immigrants. Likewise, Edith Jeffrey has demonstrated that Irish Catholics supported the ethic of discipline, self-help, and self-control found in the temperance movement..$^{5}$ The work of Walsh, Jeffrey and others researching Irish Catholic reform activities has forced scholars to reconsider the traditional view that frames Irish Catholic immigrants in nineteenth-century North America as an underclass of urban poor. ${ }^{6}$ In his essay "Governmentality," Michel Foucault argued that in order for an individual to be seen as fit to govern others, they must first learn to govern themselves, their goods, and their patrimony. ${ }^{7}$ Lay Irish Catholic temperance supporters were motivated by a desire to be

3 Clarke, Piety and Nationalism, 137, 139.

4 Victor Walsh, "'Drowning the Shamrock': Drink, Teetotalism, and the Irish Catholics of Gilded-Age Pittsburgh," Journal of American Ethnic History, 10, nos. 1/2 (Fall 1990-Winter 1991): 60.

5 Edith Jeffrey, "Reform, Renewal, and Vindication: Irish Immigrants and the Catholic Total Abstinence Movement in Antebellum Philadelphia," The Pennsylvania Magazine of History and Biography, 112, no. 3 (July 1988): 407.

6 Colleen McDannell, "True Men As We Need Them: Catholicism and the Irish-American Male," American Studies 27, no. 4 (1986): 19.

7 Michel Foucault, "Governmentality," in The Foucault Effect: Studies in Governmentality, edited by Graham Burchell, Colin Gordon, and Peter Miller, (Chicago: University of Chicago Press, 1991), 91; For valuable insights on Foucauldian governmentality and the "self-governing" individual, see Bruce Curtis "After 
seen as liberal, self-governing individuals.

Voluntary Associations and the Middle Class

Voluntary associations were at the forefront of what Ian McKay has termed the liberal revolution: material and cultural transformations in the eighteenth and nineteenth centuries in which an emergent commercial class confronted and surpassed the entrenched landed power structure. ${ }^{8}$ These transformations arose from the development of a middle class, argue sociologists Melanie Archer and Judith R. Blau, and were rooted in changes of class and occupational structure accompanying the development of industrial capitalism and urbanization. ${ }^{9}$ In the introduction to The Middling Sort, Burton J. Bledstein explored the creation of social classes, which eclipsed social rank during the eighteenth-century. Bledstein detailed the differences between social classes and social rank, remarking that whereas social ranks were determined by birth, education and manners, were not in competition with one another, and were, at least in theory, the epitome of structure and order, social classes were mobile and open. ${ }^{10}$ Further, unlike social ranks, social classes were made, not given. Such arguments reflect the seminal work of E.P. Thompson on the history and making of the English working class. Thompson famously argued that the English working

'Canada': Liberalisms, Social Theory, and Historical Analysis," in Liberalism and Hegemony: Debating the Canadian Liberal Revolution, edited by Jean-Francois Constant and Michel Ducharme, (Toronto: University of Toronto Press, 2009), especially 186-194. Curtis argues that Foucault's governmentality concept arose through explorations into the relation between technologies of domination and technologies of the self. Curtis sees the interplay between technologies of the self and subjectification as a clear way to advance our understanding of liberal development, and hence, the Canadian liberal order, 188.

8 Ian McKay, "The Liberal Order Framework: A Prospectus for a Reconnaissance of Canadian History," Canadian Historical Review 81, no. 4 (2000): 631.

9 Melanie Archer and Judith R. Blau, "Class Formation in Nineteenth-Century America: The Case of the Middle-Class," Annual Review of Sociology, 19 (1993): 18.

10 Burton J. Bledstein, "Introduction," in The Middling Sorts: Explorations in the History of the American Middle-Class, eds. Burton J. Bledstein and Robert D. Johnston, (New York and London: Routledge, 2001), 1; Bledstein has been at the forefront of explorations into nineteenth-century middle-class formation in the United States. See especially Bledstein, The Culture of Professionalism: The Middle-Class and the Development of Higher Education in America (New York: W.W. Norton \& Co., 1976). 
class were present at their own making, thus giving that group agency in their own history. ${ }^{11}$

Working within a Marxist analytical framework, Thompson saw class as a concrete,

historically specific phenomenon. Scholars who have been inspired by Thompson's work

have sought to demonstrate that working people created a shared culture that diverged from

the culture of the capitalist class. This allowed the working classes to recognize their

interests as separate from the capitalist class and thus mobilize in the interests of their

class. $^{12}$

Gordon Darroch has noted that the success of histories of the working class led to a

proliferation of studies on the development of middle-class culture in the United States from

scholars including Bledstein, Paul E. Johnson, Mary P. Ryan, and Stuart Blumin, among

others. ${ }^{13}$ The early literature on the middle class found that social composition changed over

time, from skilled artisans and merchants in the early nineteenth century, to retailers and

petite bourgeoisie by mid-century, to the rise of a professional and managerial middle class

11 E.P. Thompson, The Making of the English Working-Class (New York: Oxford University Press, 1966$), 9$.

12 The international literature on working-class life is vast. For the United States see Sean Wilentz, "Against Exceptionalism: Class Consciousness and the American Labor Movement," International Labor and Working-Class History, 26, no. 1 (1984): 1-36; For Canada see: Terry Copp, The Anatomy of Poverty: The Condition of the Working Class in Montreal, 1897-1929, (Toronto: McClelland and Stewart, 1974); Peter Delottenville, "Joe Beef of Montreal: Working-Class Culture and the Tavern, 1869-1889," Labour/Le Travail 8/9 (1981-82), 9; Gregory Kealey, “Writing About Labour," In Writing About Canada: A Handbook for Modern Canadian History, ed. John Schultz (Scarborough: Prentice-Hall Canada Inc., 1990), 145; Gregory Kealey, Toronto Workers Respond to Industrial Capitalism, 1860-1892, (Toronto: University of Toronto Press, 1980); Bryan Palmer, Working-Class Experience: Rethinking the History of Canadian Labour, 1800-1991, (Toronto: McClelland and Stewart, 1992); Craig Heron, Working in Steel: The Early Years in Canada, 1883-1935, (Toronto: McClelland and Stewart; 1988).

13 For the development of middle-class culture in the United States see Bledstein, The Culture of Professionalism; Paul E. Johnson, A Shopkeeper's Millennium: Society and Revivals in Rochester, New York, 1815-1837 (New York: Hill \& Wang, 1978); Paul Boyer, Urban Masses and Moral Order in America, 1820-1920 (Cambridge: Harvard University Press, 1978); Mary P. Ryan, The Cradle of the Middle-Class: The Family in Oneida County, New York, 1790-1865 (Cambridge, Eng: Cambridge University Press, 1981); For a useful review of this early literature see Stuart M. Blumin, "The Hypothesis of Middle-Class Formation in Nineteenth-Century America: A Critique and Some Proposals," The American Historical Review 90, no. 2 (April 1985): 299-338; also Blumin's own contribution to the canon, The Emergence of the Middle-Class: Social Experience in the American City, 1760-1900, (New York: Cambridge University Press, 1989). Gordon Darroch also cites the abandonment of postwar consensus theory as a reason why the middle class came to be studied. Darroch, "Domestic Revolution and Cultural Formation in NineteenthCentury Ontario, Canada, The History of the Family 4, no. 4 (1999): 429. 
by the later part of the century. ${ }^{14}$ Studies of middle-class formation became a controversial historiographical topic, especially among Marxist scholars. Marxist theory posits the existence of a two-class model of owner and worker in a capitalist society. Within this paradigm the existence of a middle class is viewed as inessential and transitory, eventually to become a part of one or the other of the two social classes. Because the middle class was viewed as inessential and impermanent, argued Stuart Blumin, it was seen by those working within a Marxist tradition to contain "within it no potential for genuine coherence and consciousness." ${ }^{15}$ However, the middle class was in a much more ambiguous and mobile place with respect to the production process, owing to transformations in the economy in the mid- to late-nineteenth century, particularly the rise of professional work and a commercializing economy in which service occupations such as retailers, merchants, and wholesalers were carving out a major place in the economy.

In an attempt to place the middle class as a more permanent feature in an economy that was becoming more diversified and complex than the polar extremes of Marxist theory allowed for, and to deal with the issue of class consciousness among the middle class, Blumin referred to Anthony Giddens's distinction between class consciousness and class awareness. ${ }^{16}$ Giddens argued that class awareness involves "common awareness and acceptance of similar attitudes and beliefs, linked to a common style of life, among the members of the class," while class consciousness involves recognizing that these "attitudes and beliefs signify a particular class affiliation, or the recognition that there exist other classes, characterized by different attitudes, beliefs, and styles of life." Giddens further argued that class awareness "may take the form of a denial of the existence or reality of

\footnotetext{
Archer and Blau, "Class Formation," 35-6.

Blumin, "Hypothesis of Middle-Class Formation," 303.

16 Anthony Giddens, Class Structure of the Advanced Societies, (London: Hutchinson, 1973), 23.
} 
classes." ${ }^{17}$ This was the key aspect in the formation of a middle class for Giddens, who maintained that the denial of class antagonisms in society was the fundamental aspect in the class awareness of the middle class. Blumin reformulated Giddens' conclusion, arguing that it hardly seemed possible for members of a class to be aware of similar attitudes and beliefs among members of their class without being aware that there existed other classes with different attitudes and beliefs. Nevertheless, Blumin did not object to Giddens' larger point regarding the difference between class awareness and class consciousness lying in different types of class perception, and that the middle class fit into this difference as a class that existed as a social and cultural reality without necessarily being a "conflict" group antagonistic to other social classes. A key characteristic of the middle class as laid out by Giddens and Blumin, then, was either its denial of social classes in society, or of its nonantagonistic role in society. Thus, whereas traditional studies of class in society saw social classes in an antagonistic relationship with one another, early studies of the middle class did not see the middle class as inherently antagonistic to other classes owing to its lack of class consciousness, strictly defined.

However, scholars soon began to argue that middle-class articulation did involve the development of a more typical class-consciousness in which this ideology was transmitted throughout society, as a hegemonic effort to institute middle-class supremacy and normalize its value system. Voluntary associations have been framed as ways in which this ideology was expressed in society. In their exploration of voluntary associations as an aspect of English middle-class identity, for instance, Lenore Davidoff and Catherine Hall observe that these associations were effective political tools for the liberal revolution in which merchants, farmers, mechanics, and others of the emergent middling sort could demand independence

17 Blumin, "Hypothesis of Middle-Class Formation," 308. 
from aristocratic patronage. This independence, Davidoff and Hall note, "was not to be conferred by the gentry; it had to be won." ${ }^{18}$ Kevin James observes that in Ireland, the principles of voluntarism underpinned significant institutions of sociability and middle-class political mobilization. While James notes that Irish associations were divided between evangelical Protestant organizations like the Orange Order and Catholic Repealers, he nonetheless argues that each were middle-class institutions that became important vehicles to achieve political objectives and construct and express collective identities. ${ }^{19}$ Archer and Blau likewise argue that the spirit of voluntarism swept American cities in the nineteenth century, and organizations originally composed of wealthy elites by this juncture came to be composed of urban middle-class professionals. ${ }^{20}$

Along with the economic and material changes in society leading to the establishment of a middle class came a liberal democratic revolution in values. Davidoff and Hall observed that although the nascent middling class in eighteenth-century England had much in common with the aristocracy and gentry, it was in large part the value system that set them apart. ${ }^{21}$ Archer and Blau remark that cultural historians have linked economic changes associated with the rise of a middle class with codes of middle-class culture that helped to shape a common class identity in the United States during the late nineteenth century. ${ }^{22}$ They cite Raymond Williams's work on the emergence of a "structure of feeling" as the expression and legitimization of middle-class behaviour and ideals. ${ }^{23}$ The cultural aspects of this newly formed group - including the liberal values of industry, thrift, sobriety,

18 Lenore Davidoff and Catherine Hall, Family Fortunes: Men and Women of the English Middle Class, 17801850, Chicago: University of Chicago Press, 1987), 419.

19 Kevin James, "Dynamics of Ethnic Associational Culture in a Nineteenth-Century City: Saint Patrick's Society of Montreal, 1834-56," Canadian Journal of Irish Studies 26, no.1 (2000): 50-51.

20 Arrcher and Blau, "Class Formation," 32.

21 Davidoff and Hall, Family Fortunes, 18

22 Ibid. 30.

23 Ibid. 
self-improvement, and discipline — were becoming increasingly dominant, and a major historical topic has been to explore how middle-class ways of life were spread and normalized. In Canada, Jeffrey McNairn has engaged with this question by defining voluntary associations as "self-governing organizations of open and voluntary membership electing their own officers 'untrammelled' by state control."24 For McNairn, voluntary associations were training grounds for democratic sociability where people learned how to properly function in a society whose locus of authority was shifting from the pre-modern to the modern, liberal, and democratic. ${ }^{25}$ Associations were thus instruments used by the rising classes to battle the power of established authority and carve out their own social milieu with a degree of autonomy from "family, economic production, and the state." ${ }^{.26}$ Within this field, Gordon Darroch has explored changes in family structure, including the "domestic revolution," which was closely tied to the liberal revolution. This concept posited that along with material change came cultural changes in the form of new identities forged in the context of Protestant revivalism and the extension of new family structures that emphasized women's responsibility for the family, formal schooling, and the sanctification of the home. ${ }^{27}$ Another approach employed by Bruce Curtis has been to emphasize the role of education in transmitting middle-class values to the wider society. ${ }^{28}$

Allan Greer and Ian Radforth advance the perspective that voluntary associations were important in the development of the middle class and acted for them as instruments of social control. ${ }^{29}$ Likewise, in his study of middle-class formation in the Ontario towns of

24 Jeffrey McNairn, The Capacity to Judge: Public Opinion and Deliberative Democracy in Upper Canada, 1791-1854, (Toronto: University of Toronto Press, 2000), 94.

25 Ibid., 109.

26 Ibid., 109.

27 Darroch, "Domestic Revolution and Cultural Formation," 429.

28 Bruce Curtis, "Class Culture and Administration: Educational Inspection in Canada West," In Colonial Leviathan: State Formation in Mid-Nineteenth-Century Canada, eds. Allan Greer and Ian Radforth (Toronto: University of Toronto Press, 1992), 103.

29 Allan Greer and Ian Radforth, "Introduction," in Colonial Leviathan, edited by Allan Greer and Ian 
Galt and Goderich, Andrew Holman positions voluntary associations as vehicles through which the rising middle class developed and functioned as public and prescriptive bodies which "acted as training grounds for social and political leadership by members of the local middle class and as messengers of benevolence, industry, and thrift." ${ }^{30}$ While Darren Ferry generally views voluntary associations in similar terms, as tools in the economic and political transformations that allowed the nascent middling classes to organize on the basis of shared economic interests, and define both their relationship to one another and to other social classes, ${ }^{31}$ he does not see temperance societies as being wedded to the emerging liberal state as, for example, Mechanics' Institute were. ${ }^{32}$

Ferry argues that community was central to the liberal order. ${ }^{33}$ A liberal community, according to Ferry, is one that is grounded in inclusiveness toward all occupations, class interests, religious affiliations, and political parties, as well as being dedicated to the promotion of honest industry. ${ }^{34}$ Ferry argued that temperance societies adhered to the labour theory of value, whereby individual labour contributed to a liberal community and intemperance was a bar to honest industry. ${ }^{35} \mathrm{He}$ asserted that this social philosophy was consistent throughout the nineteenth century, though the objects of censure changed. In the 1870s and 1880s, urban fraternal temperance orders, for instance, focused on how "workingmen became idle wastrels as a result of drinking," which was a far cry from the condemnation piled on the "genteel upper class" for their drinking habits a few decades

Radforth, (Toronto: University of Toronto Press, 1992), 6.

30 Andrew Holman, A Sense of Their Duty: Middle-Class Formation in Victorian Ontario Towns, (Montreal: McGill-Queen's University Press, 2000), 128.

31 Ferry, Uniting in Measures of Common Good, 4. With respect to temperance, however, he does note that a more recent and persuasive argument is that the both middle and working classes used temperance at various times to advance their own objectives. 320, fn. 2 .

32 Ibid., 96.

33 Ibid., 16.

34 Ibid., 16-17.

35 Ibid., 101-102. 
earlier. ${ }^{36}$ And while he argued that early temperance societies offered, or claimed to offer, inclusivity, they in fact were an elite constituency of evangelical urban commercial interests $^{37}$ Their temperance and sectarian connections put them at odds with conservative clergymen and "reveals an emerging liberal social order in conflict with an established Tory and High Anglican" establishment. ${ }^{38}$ From this, one might conclude that middle-class temperance played a key role in McKay’s liberal revolution against the ancien régime. But Ferry instead emphasizes that though temperance associations employed the liberal rhetoric of inclusive community and honest industry, they failed to "reconcile competing classes, orders, and interests into a harmonious, united, and collectively 'liberal' temperance community." 39 The "non-sectarianism and antipartyism" of Ferry's liberal order was undercut in the temperance cause by religious, political, and class differences over prohibition. ${ }^{40}$ Moreover, he notes divisions such as the Sons of Temperance denying women equality, and he explains that working class members fell out with the commercial element and attacked their exclusivity. ${ }^{41}$ Ferry sees the politicization of temperance over prohibition as divisive and therefore illiberal ${ }^{42}$ and therefore "at odds with an emerging liberal social order." ${ }^{43}$

Ferry's emphasis on community and inclusiveness differs from McKay's argument that the concept of the individual was at the heart of the liberal social and political order. ${ }^{44}$ They agree, however, that the liberal order was compromised by its exclusions. Definitions

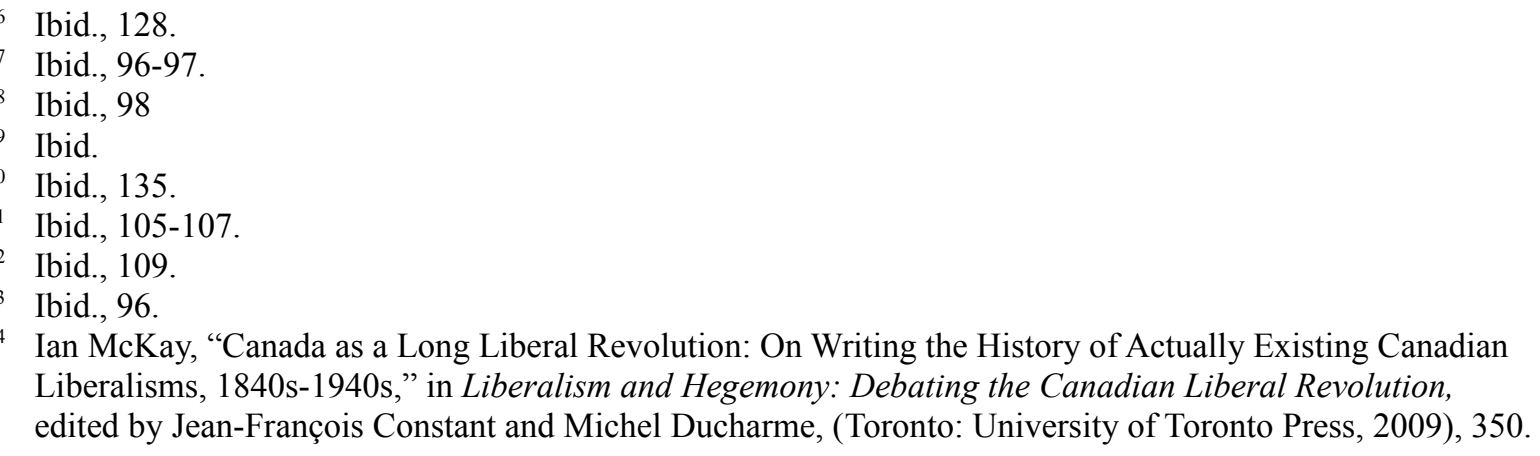
Liberalisms, 1840s-1940s," in Liberalism and Hegemony: Debating the Canadian Liberal Revolution, edited by Jean-François Constant and Michel Ducharme, (Toronto: University of Toronto Press, 2009 ), 350. 
of liberalism, according to McKay himself, have historically been "slippery." 45 The divergence between McKay and Ferry on what constituted the central element of the liberal order indeed demonstrates this lack of consensus. Nevertheless, taking aspects of the contrasting definitions formulated by McKay and Ferry and applying them to the Irish Catholic temperance movement shows that it promoted liberal values. It would appear that owing to clerical authority and ethnic attachment Irish Catholic temperance associations exemplify Ferry's point about religious and ethnic differences undercutting a liberal sense of community. But if one accepts McNairn's argument that voluntary associations were training grounds for the public sphere, one might reasonably expect such organizations to be inclusive, perhaps, but certainly not politically neutral. Irish Catholic temperance associations functioned as conduits through which the Irish Catholic middle class schooled its members in public debate and expressed a hegemonic middle-class culture. Central to this project was the attempt to present Irish Catholics as self-governing, liberal individuals. In the sense that this project was about collective social uplift it can be seen as promoting a sense of Irish Catholic community, but on middle-class terms.

\section{Class Identity and Values in Irish Catholic Temperance Societies}

The liberal values of honest industry, self-government, self-improvement, and individual success were advocated by lay leaders of the Irish Catholic temperance movement. Thomas Ryan spoke of such values during his presidential address at the 1853 St Patrick's Day dinner in Montreal. Ryan came to Canada from Ireland, where his parents sent he and his two brothers to the Jesuit College, Clonglowes Wood, in Kildare. Ryan attended the College from 1815 to 1822 , at which point he and his brother Edward emigrated to Quebec City to

45 Ibid. 
enter into business. ${ }^{46}$ Ryan had achieved sufficient prestige to have been elected president of Montreal's St Patrick's Society in the 1850s. Ryan was successful in the commercial shipping business, and would be appointed to the Senate in 1867 . During his 1853 presidential address, Ryan looked round at the officers of the St Patrick's Total Abstinence and Benefit Society who were seated at the head table and said he felt assured that those officers would act as guarantors that no excess would be indulged in. He hoped that all gathered there that evening would follow their example as closely as possible on this or any other day. Ryan expected that people would not forget the evil consequences of intemperance, and that every Irishman would unite in discouraging and preventing any offense, no matter how trivial, that was calculated to disgrace their country. If such a sentiment prevailed, Ryan continued, it would ultimately prove beneficial to all and render their prospects and careers in Canada bright and successful. ${ }^{47}$

Temperance was thus a vehicle through which Irish Catholics expressed a respectable middle-class identity and staked their claims to citizenship. Here I am using citizenship in a more figurative than a legal sense referring to hegemonic perspectives on the values and qualities seen as making one fit for citizenship in the liberal order. ${ }^{48}$ Nineteenth-century Canada underwent a transformation in which the social philosophy and economic doctrine of liberalism became dominant and supplanted traditional forms of power and authority that rested upon paternal governing structures and a Protestantism linked to the British imperial project. Even within this environment in which the locus of authority and power was

46 George MacLean Rose, A Cyclopaedia of Canadian Biography: Being Chiefly Men of the Time, (Rose Publishing Company: Toronto, 1886), 581; Gerald J.J. Tulchinsky and Alan R. Dever, "RYAN, THOMAS," in Dictionary of Canadian Biography, vol. 11, University of Toronto/Université Laval, 2003-, accessed January 6, 2014, http://www.biographi.ca/en/bio/ryan_thomas_11E.html

47 True Witness and Catholic Chronicle, (Montreal), 25 March 1853, p. 4, col. 4.

48 Engin F. Isin and Patricia K. Wood, Citizenship and Identity, (London: Sage Publications, 1999), 19; Josue David Cisneros, The Border Crossed Us: Rhetorics of Borders, Citizenship, and Latina/o Identity, (Tuscaloosa: University of Alabama Press, 2013), 4. 
shifting, Irish Catholics continued to face anti-Catholic and anti-immigrant sentiment from the Protestant majority. In seeking to take their rightful place in the liberal social order, ambitious Irish Catholics aimed to show they could govern themselves and thus be fit to govern others and perform a respectable middle-class identity.

While Thomas Ryan rhetorically espoused liberal, middle-class values and achieved social advancement and respectability through sobriety, he linked these liberal values to his ethno-religious identity. Indeed, Ryan's views on the importance of linkages between alcohol consumption, ethno-religious identity, and achieving respectability were reflective of widely-held beliefs within the Canadian Irish Catholic community. Barriers for Irish Catholics existed in Canada and across the Empire, the strongest of which was the negative view of Irish Catholics. Scholars such as John Wolffe have noted that there existed a strong link between imperial and anti-Catholic rhetoric, ${ }^{49}$ while studies by L. Perry Curtis stress the preponderance of demeaning cultural stereotypes throughout British imperial society that presented the Irish as something less than human. ${ }^{50}$ Though it has been famously argued that Canada was transforming from a British colony to an independent nation state during the nineteenth century, it nonetheless remained a part of the British world and shared its dominant mentalities. ${ }^{51}$ As Paula Hastings has argued, "English Canadians continuously negotiated their position within the British Empire and their constructions of British identity

49 John Wolffe, "Anti-Catholicism and the British Empire, 1815-1914," in Empires of Religion ed. Hilary Carey, (London: Palgrave Macmillan, 2008), 43.

50 L.P. Curtis, Apes and Angels: The Irishman in Victorian Caricature, (Washington: Smithsonian Institution Press, 1971), 29. Curtis asserts that anti-Irish sentiment was racialized, as Victorian caricaturists simianized Irish features so that the Victorian stereotype of Paddy looked more like an ape than a man. Racialized Irishness and whiteness within Irish studies has been a hotly contested topic with major titles including David Roediger, The Wages of Whiteness: Race and the Making of the American Working Class (London; New York: Verso, 1991) and Noel Igantiev, How the Irish Became White, (New York: Routledge, 1995). For a refutation of the whiteness theory in Irish studies, see David A. Wilson, "The Whiteness of Ireland Under and After the Union. Comment: Whiteness and Irish Experience in North America," The Journal of British Studies 44, no.1 (January 2005): 153.

51 Arthur R. M. Lower, Colony to Nation: A History of Canada, (Don Mills, Ontario: Longmans Canada Limited, 1946). 
were often inspired by domestic circumstances." 52 Irish Catholic migrants to Canada at this juncture were living firmly within a British culture that viewed them on not quite equal terms. Irish Catholics aimed to overcome real or perceived inequalities and find their place in Canada through various social, cultural, and economic activities. Faced with discriminatory and prejudicial attitudes, integrating and advancing meant having to differentiate themselves from crude caricatures of Irish identity. Ambitious Irish Catholics in Canada sought to individually and collectively remake themselves.

Emphasis on social uplift and achieving respectability through temperance was not uncommon among marginalized groups in the nineteenth century. In her study of nineteenthcentury African Canadian temperance societies, for instance, Lorene Bridgen argued that African Americans who entered Canada in search of freedom found their place in Southern Ontario through participation in the temperance movement which "played a major role in the African Canadian community's struggle for equality and respect." ${ }^{\prime 53}$ Temperance, Bridgen reasoned, "became a path to freedom - moral, social and political freedom. Through it Blacks could show, by example, that they deserved both liberty and citizenship. And by choosing for themselves not to drink they could gain both self-respect and the approval of the Canadian community as a whole.. ${ }^{\circ 4}$ Bridgen's conclusions regarding social uplift and community building amongst African Canadians involved in temperance recalls the work of Jan Noel on Charles Chiniquy and Paul Townend on Father Mathew, both of whom linked the temperance struggles of their subjects to their own campaigns for community uplift and

52 Paula Hastings "Our Glorious Anglo-Saxon Race Shall Ever Fill Earth's Highest Place: The Anglo-Saxon and the Construction of Identity in Late-Nineteenth-Century Canada" in Phillip Buckner and R. Douglas Francis, eds. Canada and the British World: Culture, Migration, and Identity (Vancouver: UBC Press, 2006), 101.

53 Lorene Bridgen, "On Their Own Terms: Temperance in Southern Ontario's Black Community, 1830-1860," Ontario History 101, no. 1, (Spring 2009): 64.

54 Ibid., 82. 
moral regeneration. ${ }^{55}$

The middle-class respectability of the temperance movement combated negative representations of the Irish and demonstrated collective respectability. Following the cholera outbreaks of the 1830 s and the Irish famine of the 1840s, fears regarding the influx of immigrants heightened. Recognizing these fears, Irish Catholic temperance supporters aimed to showcase how their work was helping to diminish the negative impact of the newcomers. In November 1860, John O’Reilly, the Inspector of Licenses for Ottawa, a leading member of Irish Catholic voluntary associations in the city, and a member of the Ottawa Irish Catholic temperance society, penned a letter to the Ottawa Tribune in which he noted the increase in drunkenness in the city owing to the "sudden influx of people of all classes." ${ }^{56} \mathrm{He}$ stated that among Catholics drunkenness had not increased and was in fact close to being suppressed altogether. O'Reilly attributed this triumph of temperance to the "bold front presented by the Irish Temperance Association" and the "firm determination of its members" in doing their part to curb drunkenness among newcomers to the city. ${ }^{57}$ The Irish Temperance Association, O'Reilly asserted, was "alive to the increasing responsibilities devolving upon it" and had not only "checked the evil of intemperance" but "by its moral force has caused a decided reaction (of sobriety and respectable behaviour) to set in." ${ }^{.58}$ O'Reilly positioned himself and the Ottawa Irish Temperance Association as ethnic gatekeepers regulating the potentially disruptive behaviours of incoming migrants. ${ }^{59}$

55 Jan Noel, "Dry Patriotism: The Chiniquy Crusade," Canadian Historical Review 71, no. 2 (1990): 190; Paul A. Townend, Father Mathew, Temperance and Irish Identity, (Dublin: Irish Academic Press, 2002), 85-6.

56 Ottawa Tribune (Ottawa), 10 November 1860, p. 2, col. 7; J. Castell Hopkins, The Canadian Album: Encyclopedic Canada, or The Progress of a Nation in Religion, Patriotism, Business, Law, Medicine, Eeducation and Agriculture, Vol. V, (The Bradley-Garreston Company Ltd: Brantford and Toronto, Ontario, 1896), 31.

57 Ottawa Tribune (Ottawa), 10 November 1860, p. 2, col. 7

58 Ibid.

59 Franca Iacovetta, Gatekeepers: Reshaping Immigrant Lives in Cold War Canada, (Toronto: Between the Lines Press, 2006). 
As was the case with the African Canadian temperance societies in Bridgen's study, the Irish Catholic temperance leadership such as O'Reilly were motivated by a desire to improve the lot of the collective ethno-religious identity to which they belonged. This group did not reject their Irishness because they felt it was an impediment to their middle-class respectability; instead they used their middle-class respectability to make Irish identity estimable in the eyes of wider society. Through the discursive imagery of middle-class Irish Catholic voluntary societies and symbols of Irish Catholic ethnicity such as St. Patrick's Day, Catholic Churches, harps, and shamrocks were blended into their respectability as middleclass citizens who were loyal to Crown and country. Indeed, they grafted new meanings on what it meant to be an Irish Catholic.

Since the inception of Irish Catholic temperance organizations in Canada, lay Irish Catholics who made up the leadership and committees of these organizations were content to belong to societies under Church direction. Yet lay temperance objectives differed from clerical objectives. For the clergy, a major aim of temperance and temperance societies was to extend Catholic social institutions and establish a Catholic culture as an alternative to mainstream Protestant culture within which Catholics could function. For the laity temperance was often temporal, and tied to the emergent Irish Catholic middle class. Temperance allowed lay community leaders - as well as those aspiring to community leadership - to adjust to settlement and achieve prestige within both the community and wider society. Differing clerical and lay temperance motivations could co-exist and be reconciled because both clergy and middle-class laity attempted to use Irish Catholic temperance as a means to unify the Irish Catholic population within church-approved organizations that aimed to ameliorate the disadvantaged position of Irish Catholics in 
Canada through the display of sober respectability. ${ }^{60}$ Because the Canadian Irish Catholic temperance movement blended religious and lay goals, the messages imparted through the injunctions, iconography, and public spectacles of the movement were ones of Catholicism, Irishness, and a middle-class identity.

\section{Elites in the Irish Catholic Temperance Movement}

Ruth Bleasdale remarks in her article on Irish canal workers that the Irish diaspora in Canada has largely been explored through an ethno-religious lens. ${ }^{61}$ Their Irish ethnicity, and/or their religious denomination have been the primary models scholars have employed to assess and explain the behaviours and activities of this group. To the extent that class has been explored in relation to the Irish in North America it has been the working class under examination, as in the work of Kerby Miller, H.C. Pentland, David Emmons, and Bleasdale's own study. ${ }^{62}$ Largely neglected in Irish North American diaspora scholarship is the Irish Catholic middle class and its relation to Irish Catholic ethnic identity. ${ }^{63}$ This is striking considering that members of the Irish Catholic middle class assumed prominent public roles in the shifting culture and economy of Canada and the British Empire.

The path to prosperity for Irish Catholics in nineteenth-century Canada was through the liberalizing and commercializing economy. Part of the liberal revolution was a transformation in how one acquired social standing. Thomas Laqueur has argued that in the

60 Clarke, Piety and Nationalism, 139.

61 Ruth Bleasdale, "Class Conflict on the Canals of Upper Canada in the 1840s," Labour/Le Travailleur 7 (1981), 9.

62 For class and the Irish see Bleasdale, "Class Conflict"; Kerby Miller, Ireland and Irish America: Culture, Class, and Transatlantic Migration, (Dublin: Field Day, 2008); H.C. Pentland, Labour and Capital in Canada, 1650-1860 (Toronto: Lorimer, 1981); David Emmons, The Butte Irish: Class and Ethnicity in an American Mining Town, 1875-1925 (Urbana \& Chicago: University of Illinois Press, 1990).

63 There are exceptions, such as Mark McGowan's The Waning of the Green. However, McGowan's focus is on the relationship between laity and the Catholic hierarchy and how that group became a part of a broader Catholic world. See Chapter Two of his work, "Prelates, Priests, and Professors: The Rise of a HomeGrown Church." 
ancien regime social standing was linked to inherited attributes. But throughout the nineteenth century, social standing came to depend on acquired wealth, membership in voluntaristic organizations, and on one's philanthropic or entrepreneurial prominence. In this new social world, argued Laqueur, public standing became linked with the importance one earned in the eye's of one's fellow man through earthly pursuits. One way to achieve importance was membership in respectable voluntary organizations such as temperance societies. ${ }^{64}$

While the Penal Laws are referenced as a period in Irish history when Catholics faced social and economic disabilities that rendered them a landless, poverty-ridden group, Maureen Wall suggests that a strong Irish Catholic middle class emerged in eighteenthcentury Ireland. In fact, Wall argued that the development of a prosperous Catholic middle class of traders and manufacturers occurred in some sense because of the Penal Laws, as commercial success was facilitated by laws which prevented them from investing money in politics or land. ${ }^{65}$ Some of those Irish Catholics were among the millions who emigrated across the Atlantic World and British Empire in the mid-nineteenth century. Across these vast regions, this social group established itself and evolved within national, regional, and local contexts. Others came from less successful backgrounds and worked their way up the occupational hierarchy in the new world.

Edward Murphy was example of an immigrant who came from a solidly middle-class background in Ireland and who achieved prominence in business and in Irish Catholic associational circles, as well as being accepted into the wider society in Canada. Born in Ireland in 1818, Edward Murphy was descended from "the good old stock of that name in

64 Thomas Laqueur, "Bodies, Death, and Pauper Funerals," Representations 1, no. 1 (1983): 109.

65 S.J. Connolly, "Eighteenth-Century Ireland," in The Making of Modern Irish History: Revisionism and The Revisionist Controversy, edited by D. George Boyce and Alan O'Day, (London and New York: Routledge, 1996), 23. 
the County Carlow." ${ }^{\prime 66}$ Murphy's father, Daniel, and his uncles were successful corn millers and had an extensive trade with Waterford and other large towns in the south of Ireland. ${ }^{67}$ Daniel Murphy and Mary Byrne moved Edward and the rest of the family to Canada in 1824, where they settled in Upper Canada on a tract of land of 500 acres. The family stayed there only a few short years, relocating to Montreal in 1829. Following a bout with cholera during the epidemic of 1832, Edward, at the age of 14, became employed as a clerk in the hardware trade. By 1846, Murphy was the principal salesman in the established hardware firm of Frothingham and Workman and by 1859, Murphy was a partner in the firm.

Frothingham and Workman was run by Protestants. The Irish-born William Workman was a past president of Montreal's St Patrick's Society prior to its reorganization as a purely Roman Catholic organization in $1856 .{ }^{68}$ Murphy was accepted into a Protestant firm in 1832 , when Irish associational culture was ecumenical. Murphy may have been introduced to Workman through Irish associational culture, but this avenue into Protestant business circles would not survive the confessionalization of the St Patrick's Society in $1856 .{ }^{69}$

Later in life Murphy would endow a Catholic school that emphasized commercial learning, and in 1873 he founded an annual prize "for the encouragement of commercial education" in Montreal. He was inspired to found this prize because he knew by experience "the great necessity of a good commercial education for our youth," and was satisfied that such an education "could be imparted at the Catholic Commercial Academy," which was an educational institute that operated under the auspices of the Roman Catholic School

66 "Biography of Edward Murphy" from The Harp, Vol. 5, No. 11, September 1880, 494; Rev. William Cochrane, The Canadian Album: Men of Canada, Vol. II, 245.

67 George MacLean Rose, A Cyclopaedia of Canadian Biography, 764.

68 G.Tulchinsky, "WORKMAN, WILLIAM," in Dictionary of Canadian Biography, vol. 10, University of Toronto/Université Laval, 2003-, accessed January 4, 2016, http://www.biographi.ca/en/bio/workman_william_10E.html.

69 That Catholics were not accepted into Protestant business circles was discussed in Chapter Two of this study. 
Commission of Montreal. ${ }^{70}$ Murphy's offer to found the prize was accepted, and came to consist of a cash prize of $\$ 50$, along with a gold medal valued at $\$ 25$.

Murphy's employment and later partnership in a Protestant firm did not deter him from being a leader in Montreal's Irish Catholic community. In the 1830s, he was prominent in Montreal's Repeal movement, and in 1841 assisted in forming the Irish Roman Catholic Total Abstinence Society of Montreal. Murphy was elected one of the secretaries of this organization at its formation. Murphy continued to be an active member of the temperance cause, assisting with the society at the laying of the cornerstone of St Patrick's Church. So important was Murphy to that society that in 1862 he was presented with a silver water pitcher and laudatory address to commemorate his years of valuable service to the cause of Irish Catholic temperance in the city. He was congratulated on 20 years of service and exalted for being "a good citizen and a patriotic Irishman." ${ }^{, 71}$ He was further memorialized by that society in 1872 with an oil painting of himself. Murphy was also one of the organizers of Montreal's Home Rule League in 1873, and was an active member of that organization throughout its existence but he achieved success also within the wider society of the city. ${ }^{72}$ Murphy was elected a director of the City and District Savings Bank of Montreal, and in 1877 was elected president of that institution. Murphy's hobby was scientific research, particularly microscopic work, and he lectured almost a dozen times on that subject to various temperance societies and Mechanic's Institutes across Montreal and was a member of the Natural History Society of Montreal, the Numismatic and Antiquarian Society, the Société Historique de Montréal, among other associations, all of which had memberships that crossed ethnic lines. Upon the advice of John A. Macdonald, Murphy was

${ }^{0}$ LAC, Edward Murphy Fonds MG27-1E10A, Autobiography of Edward Murphy.

1 Ibid.

72 Ibid. 
appointed Senator for the Victoria district following the death of Thomas Ryan in 1889. Murphy represented the Liberal-Conservative Party as senator until his death in $1895 .^{73}$ Murphy thus advanced Irish and Catholic causes, but was also active in non-Catholic ones that indicated his acceptance into the wider community.

John Heney, a long-time officer in the St. Patrick's Temperance Society of Ottawa, was an example of an immigrant who rose from a more humble background. Born in Cavan in 1821 , he emigrated in 1843 . He started out as a shoemaker but rapidly built it into a business with a large number of employees. In 1861 he was a merchant living in a threestorey stone house, with $\$ 11,200$ invested in his business, the 'City Boot and Shoe Store' and in real estate. Six shoemakers are listed with him, living in, and he is said to have eventually had 27 employees. ${ }^{74}$ Branching out after Confederation, Heney received the $\$ 8,000$ annual contract to supply the House of Commons and the Senate on Parliament Hill with firewood to heat those buildings, ${ }^{75}$ which opened the door to government contracting. Heney was on the Ottawa City Council from 1853 to 1890 and worked as Chairman of the Board of Works, a committee that oversaw public transit, new railways, waterworks, bridges, and roads. ${ }^{76}$ During the 1890 s, Heney transitioned his business from supplying cord wood to supplying coal $^{77}$ and in 1927 the business shifted once again to heating oil. ${ }^{78}$ So successful was the business that it was approached by Texaco to operate Texaco gas stations as part of a regional franchise. ${ }^{79}$ The offer was declined, but the Heney business remained a major player in the heating industry in Ottawa. Heney was influential in the Irish Catholic voluntary

73 Ibid;

74 Census of 1861 (online): http://data2.collectionscanada.gc.ca/1861/jpg/4108498_00841.jpg. Last accessed 6 April 2016.

75 John J. Heney, John Heney \& Son: The Saga of an Ottawa Irish Family, (Renfrew: General Store Publishing House, 2010), 44.

76 Ibid., 86.

77 Ibid., 261.

78 Ibid., 288.

79 Ibid. 
movement, especially in the cause of temperance and received a papal knighthood in 1889 . Heney came to occupy as important a place in Ottawa's Irish Catholic community as did Murphy in Montreal owing to his flair for business and his associational activities.

Owen McGarvey was heavily involved in the associational culture of Montreal's Irish Catholic community. Born in County Armagh in 1821, McGarvey, already a painter by trade, arrived in Montreal in 1838 and by 1843 had opened a paint, oil, and glass store in 1843 . He would eventually change his occupation from painter to furniture manufacturer, and this occupational change also resulted in changes to his place of business in order to accommodate increasingly large furniture showrooms, including his six-story premises at the corner of Notre-Dame and McGill which was topped by a gigantic rocking-chair. ${ }^{80}$ Along with his role as vice president in the St Patrick's Total Abstinence Society, he was director of the Montreal St Patrick's Orphan Asylum and the Montreal St Bridget's Refuge. Like Edward Murphy, McGarvey was involved in the wider society. He was a life governor of the Montreal General Hospital, life governor and vice-president of Notre-Dame Hospital, director and vice-president of the Mutual Fire Insurance Company of Montreal, a member of the Art Association, and a member of the Board of Trade. ${ }^{81}$

Murphy, Heney, and McGarvey were involved in the commercial economy of an urban centre and were able to expand their businesses and succeed in Irish Catholic associational life and achieve upward social mobility and acceptance in the wider society by taking advantage of a Canadian economy that was becoming increasingly urban, commercial, and capitalist in the second half of the nineteenth century. But, how typical were such examples? In Chapter Two of this study, based on evidence in biographical

80 Rev. William Cochrane, The Canadian Album: Men of Canada, Vol. II, 383; Elizabeth Collard, "MCGARVEY, OWEN," in Dictionary of Canadian Biography, vol. 12 University of Toronto/ Université Laval-, accessed January 6, 2014, http://www.biographi.ca/en/bio/mcgarvey_owen_12E.html.

81 Rev. William Cochrane, The Canadian Album: Men of Canada, Vol. II, 383 
dictionaries, as well as the argument advanced by William Jenkins, I concluded that Catholics on the whole did not break into Protestant business or associational circles. Yet, the examples of Murphy, Heney, and McGarvey show that there were at least some successful businessmen who did, while also remaining faithful Irish Catholics. They joined the temperance bodies early in their careers and were firm believers in their efficacy for others as well as for themselves, and they gained status within the communities (and in Heney's case papal recognition), from their central roles.

\section{$\underline{\text { Working-Class Irish Catholics in Temperance Societies }}$}

Elites like Edward Murphy, John Heney, and Owen McGarvey were successful in the wider society, and were central in the development of Canadian Irish Catholic temperance. Though membership lists are difficult to track down, the substantial number of members enrolled in Irish Catholic temperance societies suggests a wide range of class origins within these organizations. For instance, in 1840, the first year of its existence, Montreal's St Patrick's Total Abstinence and Benefit Society had enrolled 3,000 members. By 1871, the Society had 12,040 members, an increase of 505 from the previous year. ${ }^{82}$ Such high numbers suggests that not all members were elite, or even solidly middle class.

The tables below, which list committee members of temperance associations, indicate that through the course of the nineteenth century labourers and working-class members became more involved in temperance than in other Irish societies analyzed in Chapter Two. They show that the earliest societies tended to have boards consisting mostly of clergy and merchants, with practitioners of the skilled trades joining fraternal benefit societies by the 1860s, and clerks and day-labourers joining committees by the 1870s. This affirms Archer's

82 Concordia University Archives, HA 219. Proceedings of the Montreal St. Patrick's Total Abstinence and Benefit Society, 1868-71. 28 January 1872. 
and Blau's point that by the late nineteenth century voluntary associations originally composed of wealthy elites came to be composed of urban middle-class professionals. ${ }^{83}$ Ferry on Protestants and Clarke on Catholics see the same stages in temperance evolutionpledge societies giving way to skilled workers' mutual benefit fraternalist societies by the 1840s and 1850s — with the establishment of the mainstream Sons of Temperance in 1848. The SOT was an American import that recruited heavily from the working classes with a message of self-help and self-improvement, as well as alternative social attractions ${ }^{84}$ Ferry remarks that farmers and skilled workers, a traditional "producers" alliance" were strong in the executives of these temperance fraternal orders. ${ }^{85}$ Although there were no agriculturalists in these tables, as the associations were urban, we see the working class, largely skilled trades, coming into leadership positions of Irish Catholic temperance societies around midcentury.

Brian Clarke found that the working class played a prominent role in Irish temperance societies in Toronto, and the tables above suggest that this was the case across Canada. Temperance societies welcomed more working classes into committee and leadership positions than other Irish organizations. ${ }^{86}$ Like the mainstream temperance societies Ferry explored, Irish Catholic temperance organizations promoted an image of respectability and middle-class self-improvement to the working classes. ${ }^{87}$ Leaders believed that through their work advocating temperance and total abstinence, they were saving the working class from the ruin potentially brought on by intemperance. For instance, during his address on the occasion of the $50^{\text {th }}$ anniversary of Montreal's St Patrick's Total Abstinence

33 Archer and Blau, "Class Formation," 32.

84 Ferry, Uniting in Measures of Common Good, 102-103.

85 Ibid., 103.

86 See Appendices C-H. And for the tables on temperance societies, see Appendices I-K.

87 Ferry, Uniting in Measures of Common Good, 103. 
and Benefit Society, president of that society, Rev. J. A. McCallen, observed that if the number of saloons were reduced in cities then the labouring classes would have less temptation to spend their money "in the physical, intellectual and moral ruin of the drunkard" instead of toward the "comforts of a happy and peaceful home." 88

Clarke argues that the working classes were drawn to temperance societies through social and recreational activities. There was indeed a significant recreational component to the Catholic temperance movement through activities such as picnics, lectures, concerts, and excursions. ${ }^{89}$ Yet another aspect of temperance societies that drew working-class members was the benefit function, which Ferry believes was more significant in drawing workingclass members to mainstream voluntary associations. Irish Catholic societies served a social purpose providing benefit payments to members and their families. For instance, at the 1881 annual general meeting of St Bridget's Total Abstinence and Benefit Society of Montreal, treasurer Patrick Tansey reported that the Society had paid out $\$ 1780$ in benefits and donations to the Church, leaving $\$ 2879.84 .^{90}$ The dues received by the Society from members constituted the base of their benefits function. Benevolent aspects of the organizations attracted working-class members and, along with the enthusiasm of the local clerical and lay leaders, contributed to the popularity and lifespan of organizations. Montreal's St Patrick's Total Abstinence and Benefit Society offered the advantage of benevolent functions, as well as supportive clerics such as Father Phelan and Father Dowd and successful laity such as Edward Murphy. The combination of a benefits function and supportive and prominent clergy and laity meant that the society remained active until into the twentieth century, a remarkable achievement given that many Catholic temperance

8 Souvenir of the Golden Jubilee of St. Patrick's T.A.\&B Society, 1840-1890, 17.

89 Clarke, Piety and Nationalism, 143.

90 True Witness and Catholic Chronicle, (Montreal), 5 January 1881, p. 5, col. 3. 
societies survived for only a few years. Darren Ferry argues that temperance associations which offered a benefit function differed in class membership relative to societies that were solely involved in temperance and had a longer lifespan than those that did not. ${ }^{91}$ This was true for Irish Catholic temperance societies as well, as the working-class membership took advantage of the benevolent and insurance aspects of societies that provided benefits.

The St Ann's TA \& B society had a membership fee of 25 cents per month, which was used to pay $\$ 100$ to the wife or family of a deceased member upon his death, and a $\$ 50$ benefit was paid to a member upon the death of his wife. ${ }^{92}$ Laqueur and Julie Strange both argue that the working classes abhorred the possibility of a pauper funeral, seeing them as degrading to one's survivors and representative of social worthlessness, earthly failure, and abject poverty. ${ }^{93}$ They were therefore willing to join benefit societies and contribute monthly toward respectful burial. While Laqueur attributes this mentality to working class emulation of the higher classes in the context of hegemonic capitalist and earthly values becoming the measure of success, Strange attributes desire for respectful burial to personal attachment and working-class agency. ${ }^{94}$ In any event, the temperance and benefit societies who provided funeral coverage for its members allowed the working classes and lower-middle classes to have a respectful burial that would be attended by a large gathering of fellow society members. Such a funeral contributed to the social standing of the deceased and their survivors in an age when the esteem of one's peers was a measure of social success.

Benevolent temperance societies also provided insurance for the living. In 1857 the membership fee for the Halifax Catholic Total Abstinence and Benevolent Society was two

91 Ferry, Uniting in Measures of Common Good, 142.

92 Montreal Daily Star, 11 August 1894, p. 8.

93 Laqueur, Bodies, Death, and Pauper Funerals," 109; Julie -Marie Strange, "Only a Pauper Whom Nobody Owns: Reassessing the Pauper Grave, c. 1880-1914," Past \& Present 178 (2003): 148.

94 Laqueur, "Bodies, Death, and Pauper Graves," 125-126; Strange, "Only a Pauper," 150. 
dollars, with a monthly fee of twenty-five cents. This entitled members to benefits should they require financial assistance - eligible members could receive up to three dollars per week - and provided funeral coverage for needy members as well. ${ }^{95}$ The funeral allowances point to the socio-economic precariousness of members and their families, especially should the male head of the household die. The Father Mathew Association of Saint John, New Brunswick levied a fee of between twenty-five and fifty cents on each regular member in the event of the death of a member, a member's wife, or the widowed mother of an unmarried member. Its constitution noted that any member who was six months behind in their dues would forfeit membership. ${ }^{96}$ Members were thus allowed a few months grace should they be unable to afford the twelve-cent monthly fee, but ultimately they had to pay to qualify for membership. Montreal's St Bridget's TABS charged members a fee of twenty-five cents per month. A member's widow was entitled to a benefit payment of $\$ 100$ upon his death, and a member received a benefit payment of $\$ 40$ upon the death of his wife or widowed mother. In the spirit of camaraderie, every member was obliged to attend the funeral of a deceased fellow member. The constitution of Montreal's St Patrick's Total Abstinence and Benefit Society stated that after one year, a member was entitled to the Society's death benefits plan, which gave money to the family of the deceased member. If there was no family, the Society would organize and pay for the burial.

Abiding by the temperance pledge was tied to the benefit function of these societies. The Halifax Catholic Total Abstinence and Benevolent Society provided benefits to members should they require financial assistance and provided funeral coverage for needy members. To be eligible to receive these benefits, however, members had to have been

95 “Constitution and Bylaws of Halifax Catholic Total Abstinence and Benefit Society, 1857," Toronto Reference Library, Canadian Institute of Historical Microfilm 67184.

96 "Constitution and Rules of the Father Mathew Association organized at Saint John New Brunswick 9 March 1871," Toronto Reference Library, CIHM 98690 
enrolled in the society for at least a year and have "not broken the pledge." 97 Further, members would not be eligible for funeral allowance if the illness causing death had been "the result of immoral conduct." 98 However such rules did not stop people from breaking the pledge. In their records for 1843, the St. Mary's and St. Patrick's Temperance Society of Halifax noted several people who did not keep the pledge. People dropped out of membership for several other reasons, too, including death and migration. ${ }^{99}$ The rules of the society establishing sobriety as a criterion of eligibility confined payouts to victims of circumstance rather than to victims of moral failure. ${ }^{100}$

By contrast, societies that had temperance, rather than benefits, as their major aim were more lenient on the issue of pledge-breaking. Organizations that were primarily temperance associations provided benefits only as a way to compete with organizations that were primarily benevolent associations. Temperance-first societies were lenient of pledgebreaking because they wanted to keep the wayward within the Catholic fold in order to reform them. Members of the Father Mathew Association of Saint John, New Brunswick, had to take the following pledge to gain entrance into that organization: "I promise with divine assistance to abstain from all intoxicating drinks, except used medicinally by order of a medical man and to discountenance the cause and practice of intemperance." 101 In the case of individuals who broke that pledge, the penalty for the first offence was 25 cents, for the second 50 cents, and if a member broke the pledge for a third time only they would be

Ibid.

98 Ibid.

99 Archives of the Archdiocese of Halifax-Yarmouth.St. Mary's Cathedral Fonds, St. Mary's and St. Patrick's Temperance Society Series, Roll Book, 1843, 002-18.

100 This was also the case in mainstream voluntary associations. Darren Ferry recounts an incident in an Oddfellows lodge in London where a brother was suspended for three months for intemperance. Ferry, Uniting in Measures of Common Good, 150.

101 "Constitution and Rules Father Mathew Association of Saint John, New Brunswick 9 March 1857," Toronto Reference Library, CIHM 98690. 
expelled from the organization. ${ }^{102}$

Irish Catholic temperance societies, then, were made up of individuals from a range of classes. Elites like Edward Murphy, John Heney, and Owen McGarvey were successful in the commercializing economy of nineteenth-century Canada and used their roles as officeholders in temperance societies to further their entrepreneurial interests, gain prestige in the Irish community, and legitimize their place as community leaders. But lists of society officers supports Brian Clarke's suggestion that temperance societies welcomed labourers and other members of the working class as office-holders by the 1860s. Elite temperance officials like Murphy, Heney, and McGarvey strove to inculcate liberal, middle-class values, but Clarke posits that working-class Irish Catholics were drawn to temperance societies by the sociability they provided, while Ferry sees their mutual benefit or insurance functions as the primary draw.

\section{$\underline{\text { Liberal Individualism and Occupational Self-Interest }}$}

Irish Catholic temperance was grounded in Catholic faith, but this theological aspect often blended with a liberal, middle-class perspective resulting in viewpoints that reflected the merging of the spiritual and the temporal aspects of the Irish Catholic middle class. One such position was the opposition to full, legislative prohibition. In the previous chapter, I looked at how this was grounded in Catholic beliefs. But there was also a temporal, liberal aspect to Irish Catholic opposition to prohibition. In a 20 August 1852 True Witness editorial response to a letter written by a "Citizen of Maine," in which this citizen lauded the benefits of legislative prohibition in general and of the Maine Law in particular, the True Witness remarked that this person was at liberty to abstain from beer, wines, brandy, and strong

102 Ibid. 
drinks all the days of his life. All they asked of him was that he leave to others who were not of his way of thinking the right of doing, in those matters, as they saw fit. This notion of "mind your own business" was strong among nineteenth-century liberals and can be seen as a strain of individualism inherent in the liberal social philosophy.

This argument can be placed within a larger debate within nineteenth-century society that focused on the relationship between the rights of individuals and the needs of society. This perspective is in line with John Stuart Mill's argument that a social body has no right to coerce or restrict the individual unless the individual causes harm to others. ${ }^{103}$ According to Isaiah Berlin, Mill adopted a conception of negative liberty in which he wanted a "maximum degree of non-interference compatible with the minimum demands of social life." ${ }^{104}$ Lockean notions of liberty influenced proponents of the liberal order in Canada. In expanding on his initial liberal order framework, Ian McKay noted that Lockean liberal theory underpinned the liberal order: ${ }^{105}$ McKay also emphasized the centrality of property rights. Irish Catholic leaders adhered to Lockean liberalism as well. The True Witness adhered to the concept of negative liberty by opposing prohibition because of its potential for attacks upon the private property of individuals. The editorial continued: "We object to the power that is given to the police to seize upon and destroy the honestly acquired property of private individuals...(in a community where) the property of the individual is at the mercy...of any rascal or common informer...there can be no more true liberty or respect for the rights of property than there is in the empire of China, or in the dominions of the King of Dahomy." 106 Despite this call for liberty and respect for private property, True Witness did feel that the state had the right to

103 John Stuart Mill, On Liberty, (Boston: Ticknor and Fields, 1863), 7.

104 Isaiah Berlin, Four Essays on Liberty, (Oxford: Oxford University Press, 1969), 161.

${ }^{105}$ Ian McKay, "Canada as a Long Liberal Revolution: On Writing the History of Actually Existing Canadian Liberalisms, 1840s-1940s," in Liberalism and Hegemony: Debating the Canadian Liberal Revolution, edited by Jean-François Constant and Michel Ducharme, (Toronto: University of Toronto Press, 2009), 393.

106 True Witness and Catholic Chronicle, (Montreal), 20 August 1852, p. 4, cols. 2-4. 
ban certain things that were deemed evil in Christian teaching, but not alcohol because it was not inherently evil. "If the state has the same right to suppress the distillery or the tavern as it has to suppress the brothel, it must be because like the latter (the brothel) the distillery is essentially evil," they argued. ${ }^{107}$ And of course, alcohol was not evil as demonstrated by the spiritual place it held in Catholic practice. Thus, alcohol and its profits could be considered "honestly acquired property of private individuals" in a way that running a brothel and accumulating profits therefrom could not. ${ }^{108}$ The individualist, liberal argument put forth by the True Witness provided the temporal justification for the moral suasion variety of temperance, and worked in conjunction with the Church's spiritually-based moral suasion arguments.

Some Irish Catholics took this liberal logic even further and opposed the entire movement. Commercial interests and the importance of the liquor trade to the Irish Catholic business community resulted in opposition to legislative prohibition, and in some cases even opposition to the moral suasion variety of temperance. In light of the numbers of Irish Catholics who lived off the avails of the liquor trade, it was difficult for some Irish Catholics to reconcile commercial and temperance interests. Owning a tavern or saloon was also a path to prosperity in the commercial economy. William Jenkins noted that ownership of taverns and saloons was seen by the Irish as an avenue to occupational independence and social respect. ${ }^{109}$ Moreover, owing to the invaluable role keepers of taverns and saloons played in urban communities, they often became key political brokers in local politics. ${ }^{110}$ This

107 Ibid.

${ }^{108}$ Ibid.

109 William Jenkins, "Deconstructing Diasporas: Networks and Identities Among the Irish in Buffalo and Toronto. 1870-1910," Immigrants and Minorities Volume 23 Issue 2-3 (2005): 366-67.

${ }^{110}$ Ibid. The most famous Canadian example is Charles McKiernan, better known as Joe Beef. Delottenville, Peter. "Joe Beef of Montreal: Working-Class Culture and the Tavern, 1869-1889." Labour/Le Travailleur 8/9 (Autumn/Spring 1981-82): 9-40. 
sentiment was expressed by Irish Catholic Canadian Senator Frank Smith, in an 1885 speech on a resolution relating to the Canada Temperance Act and Liquor License Amendment Bill. While Smith noted that he had "never been a teetotaller," he was always in favor of temperance, and assisted that cause in every reasonable way. Yet he opposed the enforcement of temperance, calling it "a wholesale measure to wipe out every man whose calling heretofore has been that of a dealer in liquor." The liquor dealer came honestly by his business, Smith argued, and he predicted financial ruin should temperance through legislation be forced upon any municipality. "Temperance people” Smith asserted, "do not hesitate to force their views, and enforce this Act at the sacrifice of vested rights, in many cases turning people from comfortable homes on to the road." 111 Those affected would include the brewer who brewed the alcohol, the cooper who made the barrels, teamsters, book-keepers, in short, every individual connected with the liquor trade would be forced into financial ruin should prohibitory legislation be passed.

Smith was making a general argument about the importance of alcohol to the general economy. An editorial in the 1894 Catholic Register took up the issue of Irish Catholics and the liquor trade. The editorial remarked that the number of Catholics engaged in the selling and drinking of intoxicants had for years been "a subject of serious alarm." 112 It was felt that the nature of the saloon business did not "invite the best men to enter it." 113 Notwithstanding this situation, the Register argued the remedy for this anxiety-producing trade was not to be found in "attacking Catholic liquor dealers." 114 The Register asserted that many Catholic liquors sellers were fine and honest individuals, who viewed with sorrow the "unavoidable

111 Speech of the Hon. Frank Smith, delivered in the Senate of Canada, April 1885, on a resolution relating to Canada Temperance Act and Liquor License Act Amendment Bill, CIHM 01476.

112 Catholic Register (Toronto), 2 August 1894, p. 5, cols. 3-4.

113 Ibid.

114 Ibid. 
evils of their occupations." 115 The Register tied essentialized notions of an Irish identity to the success of the Irish in the liquor trade: "The traits of character which fit Irishmen for success in the liquor traffic are certainly honorable to the race...A good liquor dealer must be witty, genial, generous, and at times athletic, and these qualities are nowhere found so often as among the Irish." 116 The prevalence of Irish Catholics in the liquor trade was also blamed on anti-Irish sentiment in the wider society. "Besides fitness for dealing with men in all their humours," another cause for Irish Catholics to be found in the liquor trade, the Register continued, was because they were "ostracized in many of the other branches of trade."117 Such thinking on the Irish in the liquor trade in a sense preordained their participation; naturally fit for such service and precluded from activity in other economic sectors they, in a sense, had no viable alternative. Temperance and prohibition threatened to take this economic activity from the many successful Irish Catholics in the liquor trade. This was difficult to reconcile. For some, the individualist view on property and rights led them to oppose legislative prohibition in favour of moral suasion. Others believed that any temperance activity would be harmful to the livelihoods of Irish Catholics.

\section{$\underline{\text { Conclusions }}$}

The burgeoning of parish-based Catholic temperance societies was a consequence of ultramontane clerical attempts to create a cradle-to-grave network of Catholic social institutions that would keep lay Catholics embedded in a Catholic culture that resisted liberalism and the growth of state power in the lives of Catholics. However, the laity's acceptance of clerical authority in matters such as temperance did not preclude the leaders

115 Ibid.

116 Ibid.

117 Ibid. 
and membership of Irish Catholic temperance societies from articulating middle-class values and using these organizations to promote respectability and individual and collective social mobility. Irish Catholic temperance societies had social and benefit functions that appealed to working-class Irish Catholics, particularly those in the skilled trades. The temperance societies had more working-class leaders than were found in other Irish societies and they used their place as members and office-holders in temperance societies to achieve a degree of social prestige, which would likely not have occurred without membership in such associations.

Highlighting the Catholic temperance culture raises questions about Greer and Radforth, McNairn, and Ferry's exclusion of Irish Catholic voluntary associations. Greer and Radforth position temperance organizations as exercises in hegemonic control by dominant social classes in society, ${ }^{118}$ while McNairn sees them as key arenas within which the state, deliberative democracy, and liberalism developed. ${ }^{119}$ By contrast, Ferry views them as illiberal owing to their failure to balance different interests and thus their failure to uphold a liberal sense of community. ${ }^{120}$ However, the associations explored by Greer and Radforth, McNairn, and Ferry were British and Protestant. The Irish Catholic temperance movement had its own issues that did not always follow the trajectory of the mainstream society. There was a strong Catholic temperance voluntary culture in which the clergy held prominence and Catholic theological values were paramount. The importance that the Irish Catholic temperance movement placed on clerical authority and collective ethnic identity would seem to cast them as illiberal within the paradigm of liberalism Ferry utilized. Yet, Irish Catholic temperance societies did in fact promote liberal values of self-government, respectability,

118 Greer and Radforth, "Introduction," Colonial Leviathan, 6.

119 Jeffrey McNairn, The Capacity to Judge: Public Opinion and Deliberative Democracy in Upper Canada, 1791-1854, (Toronto: University of Toronto Press, 2000), 16.

${ }^{120}$ Ferry, Uniting in Measures of Common Good, 96. 
and individualism, and were, like Catholic newspapers, forums for learning and engaging in rational debate as McNairn argues was the case with the mainstream associations. ${ }^{121}$ Irish Catholics joined Irish Catholic voluntary associations for recreational and benefit functions, to get a sense of community belonging and as a respite from the hardening anti-Catholic attitudes in the wider society. Middle-class and working-class leaders attached sober, selfgoverning respectability to Irish identity and aimed to transform working-class members into self-governing liberal individuals and elevate their community in the eyes of the wider society.

These skills, and the support of the myriad and disparate Irish Catholic associational world, would be put to work in the 1870s challenging Irish Catholics' exclusion from the liberal state, in their quest for Parliamentary office and patronage appointments. In doing so the Irishness of these associations would challenge the British and Protestant assumptions of the Canadian liberal state, as will be explained in Chapter Seven. While in certain respects Irish Catholic temperance associations promoted values that would become dominant in the liberal order, Irish societies also expressed challenges to the liberal order and state functions through their faith and nationality.

121 McNairn, Capacity to Judge, 14. 
Chapter Five: Performing Gender and Ethnicity in Irish Catholic Temperance

\section{$\underline{\text { Introduction }}$}

The perception that Irish Catholics could not govern themselves was a dominant trope in the wider society and was disseminated through anti-Catholic imagery of drunken, povertyridden, and violent Irish Catholics. In some instances, anti-Catholic sentiment regarding the inability of Irish Catholics to govern themselves was made explicit. In some instances this was made explicit. A letter to Samuel Leonard Tilley from one James Olive explained Catholic and Protestant divisions in the Parish of Lancaster, New Brunswick and Olive expressed concern about a petition being drawn up to have the district redrawn and have Catholics appointed to the School Board. Olive declared serious doubts about the suitability of Catholics for public appointments, referring to Catholics as "persons of an inferior class, ill qualified to govern themselves, much less others."1 Olive's words were a clear expression of anti-Catholic feeling articulated in terms of governmentality. And further, as pointed out in Chapter Two's look at the newspaper analysis of Irish representation undertaken by John McCormick, the Irish themselves were well aware of the widespread dissemination of representations of the wild drunken Irish. A tract published by Montreal's St Patrick's Total Abstinence and Benefit Society asserted, "There are men who live in glass houses and yet throw stones at those whom they call the drunken Irish. Statistics prove that Ireland is not the most intemperate of the English speaking nations, but the least intemperate."2

Through temperance, Irish Catholics expressed their respectable middle-class identity and staked their claims to liberal citizenship. As the social philosophy of liberalism became dominant in nineteenth-century Canada, thereby supplanting traditional forms of power and

1 David Banoub, "The Patronage Effect: Civil Service Reforms, Job-Seeking, and State Formation in Victorian Canada," (PhD diss., Carleton University, 2013), 179.

2 Souvenir of the Golden Jubilee of St. Patrick's T.A.\&B Society, 14. 
authority that rested upon paternal governing structures and a Protestantism linked to the British imperial project, Irish Catholics continued to face anti-Catholic and anti-immigrant sentiment from the Protestant majority, who viewed them as illiberal subjects. They countered such perceptions and sought what they felt was their rightful place in the liberal social order by constructing themselves as self-governing individuals. ${ }^{3}$

Temperance was also a means of establishing and maintaining middle-class norms of gendered behaviour. In Lenore Davidoff and Catherine Hall's Family Fortunes: Men and Women of the English Middle Class, 1780-1850, a work devoted to understanding the power of separate sphere ideology among the middle classes in eighteenth- and nineteenth-century Britain, gender is presented as central in the process of middle-class formation. A principal argument they present is that "gender and class always operate together, that consciousness of class always takes a gendered form. ${ }^{" 4}$ Gender is relational: the norms and proscriptions regarding gendered behaviour impacted both men and women. Even though women were excluded from positions of leadership in the Catholic temperance movement, and increasingly excluded even from membership, middle-class gender norms were complementary and both were essential to the middle-class project. Female activity within the parish or in aid of the temperance associations articulated middle-class values.

Adele Perry argues that women stood at the margins of the nineteenth-century

Canadian liberal order. ${ }^{5}$ Liberal theory that underpinned the liberal order was anchored in the

3 Michel Foucault, "Governmentality," in The Foucault Effect: Studies in Governmentality, edited by Graham Burchell, Colin Gordon, and Peter Miller, (Chicago: University of Chicago Press, 1991), 91.

4 Lenore Davidoff and Catherine Hall, Family Fortunes: Men and Women of the English Middle Class, 17801850, (Chicago: University of Chicago Press, 1987), 14.

5 Adele Perry, "Women, Racialized People, and The Making of the Liberal Order," in Liberalism and Hegemony: Debating the Canadian Liberal Revolution, (Toronto: University of Toronto Press, 2009 ), 291. Perry was extending Ian McKay's term "entities on the edges of a liberal dominion." Ian McKay, "The Liberal Order Framework: A Prospectus for a Reconnaissance of Canadian History," Canadian Historical Review 81, no. 4 (2000): 636. 
privatization of women. ${ }^{6}$ Women were excluded from formal political subjecthood ${ }^{7}$ and from the public sphere, which helped to give the liberal order its gendered character ${ }^{8}$ as the gendered parameters of the order were being solidified and hardened. ${ }^{9}$ The liberal order project, Perry argues, was "predicated on the privatization of women and the relegation of non-Western peoples to various states of reduced humanity." ${ }^{10}$ Though marginalized from the public sphere, the privatized feminine domestic sphere was imbued by ultramontane theological and liturgical considerations with a divine mission. Domesticity within Catholic theology was linked to the exemplar of the Virgin Mary, and women's temperance activity by mid-century was increasingly centred upon an intense round of devotions both at home and in the parish church, and upon the task of countering the masculine attachment to the tavern by raising a pious generation. ${ }^{11}$ Women in the mainstream temperance movement by contrast increasingly entered the public sphere in pushing for state mandated prohibition in defence of the family. While the clerical leadership behind the Irish Catholic temperance movement constructed its expression in the public sphere as necessarily a male preserve, it raised the female cult of domesticity to the status of a divine mission within the walls of a home formulated as an extension of the parish church. Catholic experience thus expressed the gender exclusions of the liberal order in a fundamentally Catholic way.

This chapter will argue that class vision and gender norms were important parts of Irish Catholic middle-class culture and ethnic identity, and were expressed in the temperance movement. Yet gender and ethnicity functioned differently within this paradigm. Irish

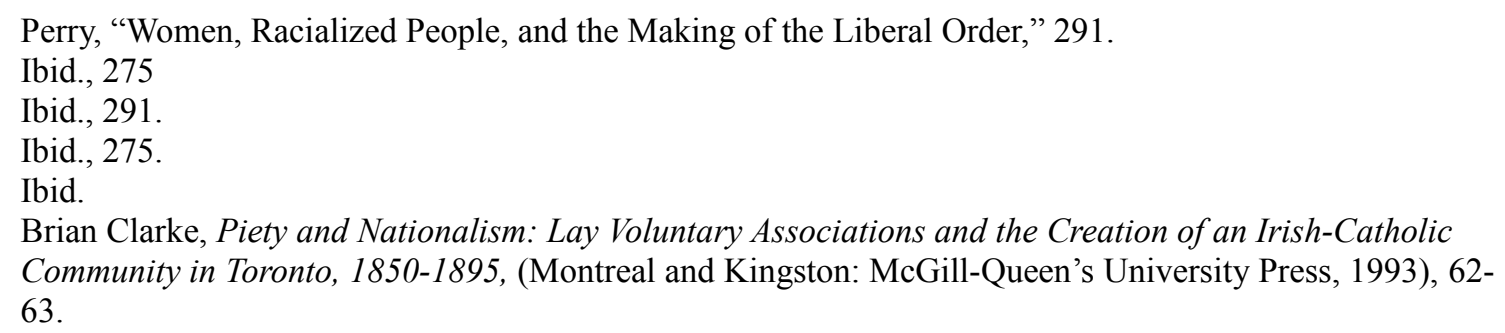


Catholic temperance entrenched the gendering of liberal Canada but for explicitly Catholic reasons. Conversely, expressions of ethno-religious difference through largely male public processions on St Patrick's Day challenged liberal British Canada's self-perception. As radical Irish nationalists came to prominence in the 1860 s, these challenges became more strident, and threatened to undermine demonstrations of Irish Catholic respectability.

\section{$\underline{\text { Irish Catholic Temperance and the Self-Regulating Male Subject }}$}

Irish Catholic temperance advocates defined and prescribed appropriate, respectable masculine behaviour - the tenets of which were sobriety and domesticity - and presented the success, happiness, and prosperity of those who adhered to this behaviour as advantages of living a temperate, respectable life. An example of these social functions within Irish Catholic associational life can be found in the words of John Joseph Curran, an Irish Catholic lawyer. ${ }^{12}$ At a meeting of the Montreal based St. Patrick's Benevolent Society in September 1866, Curran noted that the benefit provisions of the Society would provide for those who paid into the society's insurance plan, rather than see them become objects of charity or benevolence. Curran remarked that charity engendered a "sensation of dependence" which to his mind detracted from the manliness of the person receiving it. This society, noted Curran, obviated that necessity:

The member of this society who honourably discharges the duties incumbent upon him feels that even should he require to make use of it...he can do so without sacrificing that independence without which a man can scarcely consider that he enjoys the privileges of manhood...The avenues are open to all to profit by the means of self-improvement which are offered to everyone and it depends entirely on yourselves whether you shall profit by these advantages or

12 Curran would also become involved in the Home Rule movement in Montreal. The True Witness detailed a meeting of the Montreal branch of the Irish Land League that was called to protest the arrest of Parnell where Curran was one of the speakers. True Witness and Catholic Chronicle, (Montreal), 26 October 1881, p. 6, cols. 1-4. Curran would go on to become Solicitor General of Canada. 
not. There is no excuse in this country for the man who does not cultivate his mind...let us therefore not neglect our opportunities and we shall not only benefit ourselves individually, ameliorate our position as a people but reflect back credit and honour on that old land which we all love so well and for whose name and whose cause no sacrifice has ever been considered too great. ${ }^{13}$

Curran's views reflect the themes outlined in the literature regarding voluntary associations and the middle class. The familiar tropes of moral discipline, self-improvement, and manliness grounded in financial independence are evident. This thinking has typically been associated with British and American Protestants who constructed a middle-class perspective and aimed to shape society based on those values. Curran's speech, however, suggests that key values associated with middle-class masculinity were widespread within Irish Catholic associational life.

While middle-class messages of self-improvement, moral and financial independence, and the value of work in a commercializing economy showed many similarities across ethnic lines, they carried different cultural meanings for Irish Catholics. It was essential that the collective identity of Irish Catholics be tied to Catholic theology as well as this brand of self-improving middle-class respectability owing to the prevalence of anti-Irish and anti-Catholic discourse. ${ }^{14}$ Participation in middle-class Irish Catholic voluntary associations was seen as a way to prescribe and enforce middle-class values among members and train them to participate in the wider society. The goal was to transform perceptions of what it meant to be Irish and Catholic. Gender, class and ethnic formation, were therefore

13 True Witness and Catholic Chronicle, (Montreal) 28 September 1866, p. 5, cols. 2-3.

14 For a look at anti-Irish sentiment in the press see L.Perry Curtis Apes and Angels: The Irishman in Victorian Caricature, (Washington: Smithsonian Institute Press, 1971). The extent to which the Irish faced discrimination and prejudice has been rethought by scholars. See Richard Jensen, “'No Irish Need Apply:' A Myth of Victimization," Journal of Social History, 36, no. 2 (Winter 2002): 405-429. However, the importance of anti-Irish and anti-Catholic sentiment seems to be less in its existence than in the fact that many Irish Catholics, even successful ones, perceived themselves to be in a hostile environment, and was cited by contemporary Irish Catholics as motivation for many of their socio-cultural activities. Indeed, this sentiment is evident in Curran's speech. 
processes that cannot be separated.

Studies of masculinity have highlighted divergent masculinities and the ways in which certain forms were seen as superior to others. As John Tosh and Michael Roper argue in the introduction to Manful Assertions, "dominant or hegemonic masculinities function by asserting their superiority over the other, whether that be gay men, younger men, women, or subordinated ethnic groups." 15 The dominant ideology amongst middle-class Irish Catholics of this period was a respectable, domestically-oriented masculinity. Colleen McDannell argued that promoters of this form of masculinity in the United States hoped to curb the disruptive and anti-social tendencies of Irish Catholic men. ${ }^{16}$ Excessive consumption of alcohol challenged the respectable masculinity advocated by temperance promoters. Drinking was a fundamental element of Irish male cultural life, particularly among the labouring classes. Anti-Catholic and anti-immigrant commentators saw Irish Catholics as especially prone to drunkenness and violence and used this to construct negative stereotypes of Irish Catholics. ${ }^{17}$ One such stereotype was the rough masculinity of the immigrant working-class man. Irish Catholic temperance discourse sought to counter this through the promotion of domestic masculinity.

The Catholic Church's moral suasion position made exemplars especially important, with Christ himself as the prime exemplar for Catholic men. Archbishop John Walsh opened his address to the St. Paul's branch of the League of the Cross in Toronto in 1893 by

15 John Tosh and Michael Roper, "Introduction," Manful Assertions: Masculinities in Britain Since 1800, (New York and London: Routledge 1991), as cited in Carol E. Morgan, Women Workers and Gender Identities, 1835-1913: The Cotton and Metal Industries in England, (London and New York: Routledge, 2001), fn. 93, p. 192.

16 Colleen McDannell, "True Men As We Need Them: Catholicism and the Irish-American Male," American Studies 27, no. 4 (1986): 19.

17 Nathan Glazer and Daniel P. Moynihan, Beyond the Melting Pot: The Negroes, Puerto Ricans, Jews, Italians, and Irish of New York City, (Cambridge: M.I.T. Press and Harvard University Press, 1963), 257258; Kevin Kenny, The American Irish: A History, (New York and London: Routledge, 2000), 201; William H.A. Williams, T'was Only an Irishman's Dream: The Image of Ireland and the Irish in American Popular Song Lyrics, 1800-1920, (Urbana: University of Illinois Press, 1996), 152-153. 
remarking that the aim of that organization was to promote the virtue of temperance not only in the person of its members but by the "powerful influence of good example."18

Disseminating that representation through various mediums was a central component of the Irish Catholic temperance movement. Walsh went on to say that the first law God imposed upon man was abstinence and that the breaking of that law brought on all the sin and misery that existed in the world. And when "Christ came down upon earth to rectify the evils of the world," Walsh continued, "He showed the example of self-denial and when He hung upon the cross his executioners were moved to pity and offered him wine mingled with myrrh to quench his thirst." Christ refused this and in doing so, according to Walsh, "set an example to all mankind of sobriety and total abstinence." ${ }^{19}$ Walsh's use of Christ as a good example in temperance rhetoric reflects the importance of religion in the daily practices of Irish Catholic middle-class culture. It was Catholic belief that drove the Irish Catholic temperance movement to reject the state as an instrument to suppress drunkenness and instead to employ "good examples" of total abstainers to set straight those who excessively imbibed.

\section{The Complementarity of Catholic Masculinity and Femininity in the Liberal Order}

Because of the Church's emphasis on respectable, domestic masculinity, and the idea in the devotional revolution that women had an especially exalted role and a divine familial mission, women were not nearly as active in Catholic as in Protestant temperance circles. Brian Clarke has argued that differences existed between Protestant and Catholic female voluntary associations, as Catholic ones were positioned within Catholic culture and were

18 Catholic Register (Toronto), 19 January 1893.

19 In Walsh's speech, Jesus refuses wine on the cross, yet in an interesting instance of the same Biblical anecdote being used to support opposing arguments, a True Witness editorial noted in f.58 of Chapter 3 Jesus accepted the wine on the cross. 
tied to devotional practices. ${ }^{20}$ A key part of the masculinity of the Irish Catholic temperance movement was its relation to feminine gender norms, and domesticity became the concept around with Catholic masculinity and femininity intersected. The shift of temperance activity that saw women take on increasingly prominent roles in mainstream organizations such as the Women's Christian Temperance Union was precluded amongst Catholics by clerical leadership. Though women had previously belonged to Catholic temperance organizations, ${ }^{21}$ Clarke argues that by the early $1860 \mathrm{~s}$, Catholic temperance societies no longer recruited or even welcomed female members and the societies became exclusively male organizations. Clarke argues that the context for female Catholic temperance work became the devotional organization, which gave them authority in the home but not in the public sphere. ${ }^{22}$ Many organizations, such as the Father Mathew Association of St John, New Brunswick, did not allow female membership. The objective of that society was to "promote total abstinence among the Catholic young men of St John." ${ }^{23}$ Likewise, in the preamble to the constitution and by-laws of the Halifax Catholic Total Abstinence and Benevolent Society, it was specifically noted that that organization would be a male-only association. ${ }^{24}$ In instances where females were not expressly prohibited from joining Catholic temperance societies, the conditions of their involvement were spelled out. For instance, the St Patrick's TABS of Montreal had two kinds of members, ordinary and regular. The regular members of the society were members of the benefit branch, while ordinary members were not entitled to insurance. Only males were eligible to be regular members of the society.

20 Clarke, Piety and Nationalism, 89.

21 Archives of the Archdiocese of Halifax-Yarmouth, St Mary's Cathedral Fonds, St Mary's and St Patrick's Temperance Society Series Roll Book- 1843, 002-18.

22 Clarke, Piety and Nationalism, 135.

23 Constitution and Rules of the Father Mathew Association, Organized at St John N.B., March $9^{\text {th }}$ 1871, 3.

24 Constitution and by-laws of the Halifax Catholic Total Abstinence and Benevolent Society, Founded $2^{\text {nd }}$ Feb'y., 1857 by the Rev. John Higginbotham, 3. 
According to the by-laws of that organization, "all persons without distinction shall be admissible to become ordinary members of the Society" by taking the pledge and paying an admission fee of 15 cents. But only "male members between the age of 14 and 50 years" were eligible to become regular members of the society and be entitled to the benefit by paying a 25 cent admission fee and 25 cents monthly thereafter. Moreover, in the by-laws of the society covering the death benefit function, all references were to benefits being paid out to women as defined by their relationship to the deceased male member. For instance, upon the death of a married member in good standing living with his wife at the time of his death the sum of $\$ 100$ would be paid to his widow, or upon the death of the wife of a member in good standing, the member would receive a sum of $\$ 50$. It was also noted that in cases where the society deemed that the wife of a deceased member was not "a fit or proper person to receive aforesaid benefit," the committee of the society were empowered to dispose of the benefit in "whatever manner they may deem best in the interests of the deceased member's family." 25

Even as the Catholic temperance movement shifted to international organizations, women continued to be unrepresented owing to the clerical control exercised in these broader associations and the fact that they were made up of parish and diocesan temperance societies. It was not until the 1890 s and into the twentieth-century that dioceses began to have female temperance societies separate from male ones. ${ }^{26}$ Deirdre Moloney argues that toward the end of the nineteenth century, American Catholic laywomen of the middle and upper classes were at risk of being seen as idle, frivolous, and prone to material excess. Catholic women could dispel such charges by engaging in voluntary religious work, seen as

${ }_{25}$ Souvenir of the Golden Jubilee of St. Patrick's T.A.\&B Society, 45-47.

26 Joseph Gibbs, History of the Catholic Total Abstinence Union of America., (Philadelphia: Penn Printing House, 1907), 221. 
an extension of their domestic roles. ${ }^{27}$ Temperance, then, became a way for women to engage in the public life of the parish, be seen as doing good works, and retain their domesticity. In Boston a female temperance society was founded in 1889, while the first women's Catholic temperance society in Philadelphia was founded in 1880, "in the belief that to a considerable extent the success of the temperance movement depended upon the women of America." ${ }^{28}$ In Philadelphia in 1907, there existed 36 women's societies with 3700 members and 29 girls societies with 3800 members. ${ }^{29}$ In 1889, women delegates were invited to the Connecticut state convention of the CTAU, and a woman, Mary Davis, was elected second vice-president of the CTAU of Connecticut, the first woman to hold such a position. ${ }^{30}$ The Ladies' Auxiliary of the Knights of Father Mathew was organized on 24 September 1894 in the St Louis Cathedral by nine women. By 1907, this organization had 1000 members in various locations in Missouri and Kansas. This organization belonged to the CTAU, sent delegates to the convention, and also had an insurance feature. ${ }^{31}$

The establishment of Catholic female temperance societies was not, however, a uniform development and depended upon the local parish and diocesan administration. For instance, it was noted in 1907 that in the Diocese of Scranton, Pennsylvania, where 1500 members belonged to the CTAU and cadet associations thrived as "feeders to the adult branches, thereby imbuing every element with the spirit of total abstinence," no special

27 Deirdre Moloney, American Catholic Lay Groups and Transatlantic Social Reform in the Progressive Era, (Chapel Hill and London: University of North Carolina Press, 2002), 174. And was will be shown below, Catholic women in Canada were involved in the public life of the parish through charitable bazaars.

28 Gibbs, History of the Catholic Total Abstinence Union of America, 207.

29 Such high numbers are unsurprising given the large population of Catholics in Philadelphia. Between 1872 and 1907, \$659, 830 was paid in death and sick benefits by Catholic temperance societies in the city. And in 1876, the centenary of Daniel O'Connell was celebrated in Philadelphia by erecting the Catholic Temperance Fountain in Fairmount Park. Gibbs, History of the Catholic Total Abstinence Union of America, 206.

30 Ibid., 192.

31 Ibid., 200. 
efforts had yet been made to organize women's societies. ${ }^{32}$ One must consider whether Catholic women supported the temperance movement or not. In Protestant circles, temperance is often seen as a vehicle through which women could, and did, enter the public sphere and the political realm. In Catholic temperance, however, the clergy's control differentiated the movement from the lay-led Protestant movement. Indeed, the St Louis organization noted above was not an independent organization, but rather an auxiliary association. Perhaps Catholic women, at this juncture at least, did not feel that temperance agitation could result in their participation in the public sphere. For instance, in Louisiana, it was remarked that the temperance cause had weakened by the $1890 \mathrm{~s}$, in part because "women did not give the moral support expected of them." 33 While this statement could be read as blaming "immoral women" for the decrease in temperance activism in Louisiana, it could simply be a case of women not being interested in belonging to the Church-run temperance movement, or to any temperance movement for that matter. In any event, the advent of female-only Catholic temperance societies in Canada, haphazard as it was, does not seem to have occurred during the period under review in this study. Female involvement in the public life of the parish would remain largely auxiliary and work to solidify the links between women and the domestic. ${ }^{34}$ While indeed Canadian Catholic women were involved in parish devotional and benevolent associations, which allowed them to carve out a social space within the male-dominated Catholic Church, ${ }^{35}$ they were not as involved in temperance as their American counterparts.

Yet the lack of females in Irish Catholic temperance societies did not mean that representations of femininity and "ideal womanhood" were absent. Domesticity

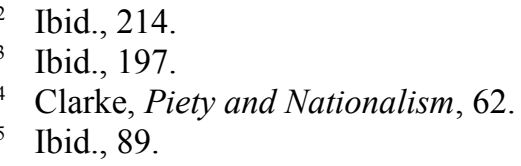


stereotypically associated with women was a central element of the masculinity promoted by Irish Catholic temperance societies and shaped ideas about both men and women.

Temperance discourse often presented women as victimized by men practicing rough masculinity: excessive alcohol consumption, violence, squandering the family's money on booze. As one editorial in the Irish Canadian put it, "the cause of temperance bears with especial importance upon women. The vice of drunkenness may be her husband's, but the suffering is sure to be hers." ${ }^{36}$ By contrast, "respectable" men took care of their domestic lives of sobriety and order. In both cases, women were presented as being dependent upon the masculinity of the man. The difference was that while women were victimized by rough masculinity, they benefited from respectable masculinity. Among Irish Catholics protection of women carried nationalist overtones as well. Ireland was often feminized and represented as a "damsel in distress" owing to the political subjugation to English rule. As Cian McMahon points out, the subjugated and feminized representation of Ireland in nationalist discourse evoked anxiety over national emasculation. The representation of strong, respectable, domestic masculinity protecting femininity in Irish Catholic temperance discourse was meant to signify the respectability of the Irish Catholic male, and also position him as protecting the Irish race and nation from English imperialism. ${ }^{37}$

Employing scenes of domesticity to counter images of rough masculinity was a common strategy within Irish Catholic temperance circles. Brian Clarke notes that Catholicism developed a cult of domesticity that through its "devotional observances sacralized the home as well as women in their capacity as the preservers and defenders of the home's sanctity." 38 The role of femininity in the construction of a masculine gender ideal was

36 Irish Canadian (Toronto), 22 November 1876, p. 4, col. 3.

37 Cian T McMahon, "Caricaturing Race and Nation in the Irish American Press, 1870-1880: A Transnational Perspective," Journal of American Ethnic History 33, no. 2 (Winter 2014): 34.

38 Brian Clarke, "The Parish and the Hearth: Women's Confraternities and the Devotional Revolution Among 
important, so feminine identity was not simply reliant; masculinity and femininity in the Irish Catholic temperance movement were relational. A type of femininity was prescribed and was necessary to round out the domestic masculinity of Irish Catholic males. This was reflected in Father James McCallen's Father Mathew lectures from 1890. McCallen was the president of the Montreal St Patrick's TABS and his two lectures were given in honour of the centenary of Father Mathew. They took place on 12 October 1890 in St. Ann's Church in Montreal and on 26 October 1890 at St. Patrick's Church. ${ }^{39}$ Rather than framing women as the potential victims or beneficiaries of the type of masculinity performed by the men in their lives, McCallen instead positioned women as determining the masculinity of the man because of her potential role as a supplier of drink. He remarked "how often has not the downfall of once sober and respected men been traced to women's weakness in this matter?" ${ }^{40}$ McCallen asked women, "Is it not possible to have a few gentleman friends visit your homes without setting before them ale, beer, and strong liquors?"41 McCallen thus positioned the type of masculinity of the man as dependent upon the type of femininity of the woman.

The type of femininity deemed ideal by middle-class Irish Catholic cultural leaders was analogous to the gender ideals disseminated in the wider society. As Clarke declared, "the cult of domesticity was a middle-class social ideal, but one that was supported by Catholic piety." ${ }^{42}$ This was laid out in a reprinted article published in the Irish Canadian

the Irish Catholic's of Toronto, 1850-1895." In Creed and Culture: The Place of English-Speaking Catholics in Canadian Society, 1750-1930 edited by Terrence Murphy and Gerald Stortz, (Montreal and Kingston: McGill-Queen's University Press, 1993), 194-5. Clarke also notes that this process was especially apparent in the devotions to the Virgin Mary.

39 CIHM 25578, Toronto Reference Library, "Temperance Lectures Delivered in St. Patrick's and St. Ann's Churches: A Grateful Tribute to Father Mathew's Memory and Work."

40 Ibid.

${ }^{41}$ Ibid.

42 Clarke, Piety and Nationalism, 77. 
entitled "Women and Home". It noted that the ideal place for the "really womanly woman" was in her home and her true mission was to make her husband and her children happy. ${ }^{43}$ Such a woman, the article continued, is not concerned with notions of "her sex's rights."44 She does not attend meetings or conventions, does not demand a seat on the bench, a post in the state, or even a vote through the ballot box. This "really womanly woman" does not campaign for these social changes, but instead is content with the position assigned to her by the Almighty at Creation, which placed her in charge of her "appropriate" domestic sphere. The ideal woman did not attempt to overstep this sphere, but enjoyed her role therein. She made it "a charmed circle, within which the husband and father is disbursed of business cares and yields a fullness of placid happiness which the outside world can neither give nor take away." ${ }^{45}$ Another article, in the Ottawa Tribune, on "The Female Temper" stressed the importance of a woman's "sweet temper" to her husband. Let a man go home at night, the article read, "weary and worn by the toils of the day and soothing is a word by good disposition. It is sunshine falling on his heart. He is happy and the cares of his life are forgotten." 46 This classic "haven in a heartless world" perpetuated by separate spheres ideology became popular and gained prominence as individuals and society negotiated the processes of industrialization and modernity, and various types of identity became universalized and strict.

In the seal of Montreal's St. Patrick's Total Abstinence and Benefit Society, the foregrounded man represents sobriety while the woman represents domestic comfort. ${ }^{47}$ The image can be taken to mean that the man carrying the banner of sobriety allows the woman

43 Irish Canadian (Toronto), 24 November 1880, p. 3, col. 5. This article was reprinted in the Irish Canadian. The original source for the article was not given, save for noting that it was from "an exchange paper."

44 Ibid.

45 Ibid.

46 Ottawa Tribune (Ottawa), 23 February 1861, p. 1, col. 3.

47 M930-50-1-580, Seal of The St. Patrick's Total Abstinence Society, McCord Museum of Canadian History. 
to achieve domestic comfort for the household. The domestic comfort of the woman is dependent upon the man's sobriety and his respectable masculinity in general. In this representation of gender roles the woman remains dependent upon the masculinity of the man, but in this case the masculinity is the respectable, domestic middle-class variety. But we may also read the seal in light of McCallen's words. It is conceivable that if the woman in the seal did not hold the banner of domestic comfort but instead held the banner of "social drink" then the man could easily be holding the banner of drunkenness and ruin. Irish Catholic men and women each had a part to play in maintaining prosperity and domestic comfort. Men were to be sober, industrious, and protecting. Women were to be sober, in charge of domestic comfort, and regulating the household intake of alcohol. If either men or women failed to live up to these roles, drunkenness, violence, and ruin would be sure to follow.

The relationship between masculinity and femininity being necessary to assure that the ideal of each was realized was a common theme among the Irish Catholic middleclasses. The Irish Catholic temperance movement prescribed both an ideal masculinity and an ideal femininity that were relational, and centered on domesticity, sobriety, and prosperity. Both were embedded in a broader project among Irish Catholics to construct a respectable middle-class identity that encompassed sobriety and loyalty to nation. This example is thus reflective of Lenore Davidoff and Catherine Hall's assertion that "middleclass men who sought to be 'someone,' to count as individuals because of their wealth, their power to command or their capacity to influence people, were, in fact, embedded in networks of familial and female support which underpinned their rise to public prominence." ${ }^{48}$ The respectable, domestic masculinity performed by Irish Catholic middle-

48 Lenore Davidoff and Catherine Hall, Family Fortunes, 13. 
class men that allowed them to achieve and exercise authority in the public sphere and be seen as respectable citizens in colonial Canada depended in large part upon the performance of respectable, domestic femininity by Irish Catholic women.

The stereotyped images of femininity and masculinity were important in the Irish Catholic associational world and used for specific purposes. Gender ideals as promoted by the mainstream society were used in the constructions of Catholic temperance societies and voluntary culture in general. The expression of gender ideals indicates that despite their placement in the Catholic world, Catholic women and men were impacted by the larger culture of which they were a part and, moreover, helped to legitimize and extend notions of true womanhood and true manhood and the separate spheres ideology from which such notions emerged. One area in which this was prevalent was the charitable bazaar.

\section{The Charitable Bazaar and Commercial Exchange in the Liberal Order}

Charitable bazaars spread a liberal middle-class vision of domesticity, consumption, and values. Charitable bazaars were typically week long events that were held in various buildings from Mechanic's Institutes to church halls. They were charitable in the sense that the money raised was used for some pre-established purpose tied to the Irish Catholic community such as the building of a new church, repairs to an existing church, or for the running of Irish Catholic benevolent institutions. ${ }^{49}$ For instance, the Ladies of Charity of St Patrick's congregation in Montreal held bazaars for the support of the orphans of St Patrick's

49 Annette Shiell, Fundraising, Flirtation, and Fancywork: Charity Bazaars in Nineteenth Century Australia, (Newcastle: Cambridge Scholars Publishing, 2014), 19. Shiell has commented on the difference between charity bazaars and commercial bazaars. The charitable enterprises were voluntary concerns organized and managed by women of the leisured class who sold their own handiwork as a means of raising funds for a designated charity, while commercial bazaars was a means through which women in financial need could support themselves and their dependents by selling their handiwork. The charitable bazaars under review here were all organized and managed by elite and upper-class women, who were the wives of prominent Irish Catholic men such as M.P. Ryan, William Brennan, and Edward Murphy. 
Asylum. The first of these bazaars was held in October 1849, and there was a bazaar held in St Lawrence Hall every year from that point until 1884 . Owing to the prevalence of smallpox, it was deemed imprudent to hold a bazaar in 1885 , and instead raffles were held in private. For the years 1849 to 1884 , a total sum of $\$ 135,099.36$ was raised. Though such fundraising events were in aid of specifically Irish Catholic causes, attendance was open to all thus making bazaars a community, as well as a parish, event. ${ }^{50}$

Bazaars were organized and carried out by women within the congregation, and these committees made up of "ladies of the congregation" put notices in newspapers informing the reading public of their intention to hold these events, the purpose of the event, and the items available for sale. They were geared toward improving the lot of Irish Catholics, and while they were charitable events, contributions were not hand-outs because the people were receiving something in return. This was evident in a letter written by a correspondent about the 1880 St. Patrick's Bazaar in Montreal who remarked that this bazaar had "everything to make a bazaar attractive and give the patrons a chance to receive value for their money." The veneer of charity was underpinned by ethno-religious feelings, as well as market relations between buyer and seller. In the process, they promoted a strictly domestic and even exoticized view of women.

Annette Shiell has argued that bazaars were critically important in raising funds for organizations and institutions. In her study of bazaars in nineteenth-century Australia, she remarked that bazaars were such a popular and successful means of raising revenue that many of the country's major public and religious institutions owe their continued existence

${ }^{50}$ A similar point is made by Joshua Blank in his study of parish picnics in the Polish Canadian parish of Wilno. Joshua Blank, "Pitching, Pies and Piety: Early Twentieth Century St Hedwig's Parish Picnics," Historical Studies Volume 76 (2010): 75.

51 True Witness and Catholic Chronicle, (Montreal), 20 October 1880, p. 5, cols. 4-5. 
and expansion to the funds raised through the efforts of bazaar organizers. ${ }^{52}$ In addition to the financial success of the bazaars they were also successful in facilitating the presence of women in the public domain in the age of separate spheres, which removed middle and upper class women from commercial and public arenas. Shiell argues that organizing events such as charitable bazaars allowed women a legitimate role in the public sphere while upholding the ideology of domesticity and its emphasis on the sanctity of the home..$^{53}$ Focusing specifically on the Catholic case, Brian Clarke has likewise argued that as the clergy confined them to control of the domestic sphere, women made their most visible contribution to the parish in their capacity as fund-raisers and through planning bazaars. ${ }^{54}$

A middle-class vision and liberal values were built into the Irish Catholic identity espoused and promoted by bazaar organizers. Among the Irish Catholic middle-class charity and improvement were tied to a sense of ethno-religious feeling, particularly as it was hoped that raising individual Irish Catholics out of poverty would improve the lot of Irish Catholics as a collective body. An aim of the bazaars was to raise money for institutions that sought to shape the moral character of Irish Catholics. And as is usually the case with indoctrination, the younger the better. Advertisements for the St Patrick's Bazaar of 1850 noted that its purpose was to procure "funds to clothe orphan and destitute children to enable them to attend school in the winter. ${ }^{, 55}$ According to the True Witness, these efforts had been largely successful. In the previous two years, thanks to the funds raised at the bazaars, every child who was willing to attend school has been provided with every necessary comfort in terms of clothing. The aim of the organizers was to have the orphans attend school in order to create useful citizens. As the True Witness remarked, "some hundreds of children who used

52 Shiell, Fundraising, Flirtation, and Fancywork, 2.

53 Ibid., 24-25.

54 Clarke, Piety and Nationalism, 84.

55 True Witness and Catholic Chronicle, (Montreal), 11 October 1850, p. 4, cols. 1-2. 
to be found imbibing the contagion of each others vicious example have been by the exertions of those benevolent ladies induced to attend school and promise to become one day useful members of society." 56 This is part of the formation of an identity that fused ethnoreligious sentiment with liberal values such as the primacy of centralized/organized education, and being productive useful citizens.

A letter writer from Halifax described the scene at an Irish Catholic bazaar held in Halifax during the fall of 1866 for the purpose of raising funds to build a church. A simple glance, remarked the observer, showed that the ladies spared no pains to make their undertaking a complete success. Chairs, ottomans, fancy articles of every description were scattered about on the tables. ${ }^{57}$ A similar description was given for the annual St. Patrick's Bazaar held in Montreal in mid October of 1880. A description in the paper noted that this bazaar has always been the affair of the season. The event took place in the Mechanic's Hall which was always a "splendid delight to see in the evening when (it) was brilliantly illuminated." Indeed, in this description light seems to be a privileged adjective. The writer noted that "the scene was unusually bright, lively, and attractive" the tables covered with articles "enough to dazzle the eyes of those unaccustomed to such articles," the jewelry shone and sparkled under the bright lights." The articles for sale were equally lovely and included items such as a beautiful little clock, silver tea service, tapestry, and "cushions, chairs, ottomans of such surpassing loveliness that none but an aristocrat of the bluest blood could help thinking it was less than desecration to sit upon them." 58 The bazaars were spatially designed to highlight luxury and exclusivity, where domesticity and consumption were paramount.

\footnotetext{
Ibid.

True Witness and Catholic Chronicle, (Montreal), 23 November 1866, p. 5, col. 1.

58 True Witness and Catholic Chronicle, (Montreal), 20 October 1880, p. 5, cols. 4-5.
} 
Working in conjunction with the market culture surrounding the bazaars were ideas about women. The women who organized and ran the bazaars employed popular, if contradictory, ideas about the place of women in a liberal society where separate spheres was the ideal. Two representations of women that were salient to the management of these bazaars were women as sexualized objects and women as maternal keepers of the domestic sphere. The former was used to entice potential customers to attend the bazaars, while the latter was evident in the items for sale.

Notices for these events invoked national and religious sentiment, as well as the deplorable condition of the poor to get people to come to the bazaar and purchase goods. In addition to these strategies of advertising, the organizers of the bazaars used sex to sell. In her article on market relations and charity fairs "Charitable Calculation: Fancywork, Charity, and the Culture of the Sentimental Market: 1830-1880" Elizabeth Alice White asserts that the fancywork at the events she looked at "were not the only thing on display. The presence of the young women at the tables selling their work lured male consumers with the prospect of sanctioned flirtation that accompanied this kind of (sentimental) exchange." ${ }^{59}$ Shiell likewise remarked that flirtation was a key component of the charity bazaar, as they offered patrons an approved opportunity to flirt and mix outside one's family and accepted social circles in the name of charity. ${ }^{60}$ Beverly Gordon has also argued that at various points in time, bazaars have been seen as symbols of risque behaviour and rampant sexuality. ${ }^{61}$

A similar theme was evident at the Irish Catholic bazaars. Thus the following notice was placed in the True Witness regarding the St. Patrick's Bazaar of 1850: "The ladies are so

59 Elizabeth Alice White, "Charitable Calculation: Fancywork, Charity, and the Culture of the Sentimental Market" in The Middling Sorts: Explorations in the History of the American Middle Class eds. Burton J Bledstein and Robert D. Johnston (New York: Routledge, 2001), 76.

60 Shiell, Fundarising, Flirtation, and Fancywork, 285.

${ }^{61}$ Beverly Gordon, Bazaars and Fair Ladies: The History of the American Fundraising Fair, (Knoxville: University of Tennessee Press, 1998), 1. 
agreeable, so fascinating, everything so well arranged, so orderly, so pretty, such real good humour and rational enjoyment that you must really be charmed with your visit...charity on her own account should be always held in high estimation, but in the Irish Bazaar she puts on an aspect so truly agreeable that you find yourself irresistibly compelled to venerate, to love her." ${ }^{62}$ In this instance, charity was gendered female, and an irresistible female at that. And there is this ad for the Ladies of Charity of St. Patrick's Congregation Bazaar of 1865: "Do you wish to spend a pleasant evening...to hear fine ladies say the finest things imaginable - things so very fine that they may steal into your hearts and soften them, but will most assuredly steal into your pockets and empty them of any loose cash they may contain. Just visit the Irish Bazaar...At any hour, but especially from 7 to 10 in the evenings, do their best smiles await you." ${ }^{63}$

The sexualization of women at the bazaars was used to draw people to the events. Once there, this trope was transformed to emphasize the domestic nature of the items for sale. Some of the items for sale at the 1880 Montreal bazaar included mirrors, vases "cushions and rugs good enough, too good, for His Sublime Highness the Sultan of Turkey." These were goods for domestic consumption, meant to be placed in a safe, domestic setting. But in highlighting the domesticity of the items for sale inside the bazaars, the women continued to employ elements of the sexualized, mysterious female. Two women, Mrs. Agnes Burt and Mrs. Thomas Brennan, had a stall at the 1880 St. Patrick's Bazaar in Montreal. This stall was referred to by journalists as "the celebrated fish pond." Here, the "angler" would pay ten cents and take an article from the pond. Then, the "angler" would open up the package to discover what fortune has sent him. This "fish pond" was advertised

62 True Witness and Catholic Chronicle, (Montreal), 18 October 1850, p. 4, col. 3.

63 True Witness and Catholic Chronicle,(Montreal), 6 October 1865, p. 5, col. 3. 
to contain "things mysterious and things profound." ${ }^{64}$ These bazaars fused ideas about the sexuality, domesticity, and mysteriousness of women in order to create a discourse of gender in the marketing of these events. While Irish bazaars point to the important role that women played in an Irish Catholic middle-class culture that espoused liberal values, they also demonstrate the ways in which the options of these women were constrained by ideas about women.

\section{Performing Respectability on St Patrick's Day}

Though they helped maintain gender norms in liberal Canada, the lay Irish Catholic temperance movement's emphasis on their ethnic difference posed a challenge to the type of citizenship desired by promoters of liberal British Canada. This challenge was latent during periods when Irish Catholics expressed their ethnicity in ways consistent with what was considered appropriate behaviour. The willingness of the wider society to accept ethnic difference existed only when it was merged with acceptable standards of behaviour. When expressions of ethnicity veered toward the radical and threatening, such as during the period leading up to the Fenian Raids of the late 1860s, this challenge became pressing and was met with disapproval and opposition from the wider society, reflecting the fact that the issue of loyalty to Canada was defined by many Protestants in imperial terms.

St Patrick's Day commemorations were fundamental in linking temperance to Irishness and Catholicism. A celebration of Ireland's patron saint, St. Patrick's Day was celebrated in Ireland as a saint's day as early as 1607. Pope Urban VIII added the feast of St. Patrick to the calendar of the Church in $1631 .^{65}$ Following this, the seventeenth of March

64 True Witness and Catholic Chronicle, (Montreal), 20 October 1880, p. 5, cols. 4-5.

65 Mike Cronin and Daryl Adair, The Wearing of the Green: A History of St. Patrick's Day, (London and New York: Routledge, 2002), 1. 
took on a greater significance as it linked St Patrick and Ireland's Christian heritage. The first St Patrick's Day celebration in Canada took place in Quebec City in 1765, where Irish Protestant officers in the Quebec garrison of the British Army celebrated the day. This Protestant-oriented celebration makes sense considering that the Irish presence in Canada was overwhelmingly Protestant. However, as more Irish Catholics migrated, and the Catholic Church gained greater influence, the festivities took on an increasingly Catholic tone. ${ }^{66}$

Part of the growing Catholicity of St. Patrick's Day became the performance of masculine respectability, as it became used by Irish Catholic elites to signify the existence of a distinct Irish and Catholic world through public demonstrations. St Patrick's Day became an occasion to perform and display Irish Catholic respectability to both wider society and other Irish Catholics. People and resources were mobilized during this event to reflect on the unique challenges faced by their ethno-religious community in a Protestant-dominated society. Church services followed by parades were central attractions of St. Patrick Day festivities. These public rituals demonstrated the respectable religiosity and good behaviour of Irish Catholic males for all to see. Temperance societies became a part of the display of social power that accompanied these celebrations, combining as they did religious leaders, government officials, and middle-class respectability.

Parades are claims to control over public space. Peter Goheen has observed that parades were important instruments that allowed for the public expression of the many values and viewpoints contending for attention in a dynamic urban context. ${ }^{67}$ The authors of An Introduction to Political Geography likewise argue that parades are "acts of territoriality"

66 Ibid.

67 Peter G. Goheen, "Symbols in the Streets: Parades in Victorian Urban Canada," Urban History Review, Vol. 18, no, 3 (February 1990): 237. 
in which each community lays claim to streets and neighbourhoods to the temporary exclusion of other actors and makes explicit their community's presence in those areas. ${ }^{968} \mathrm{St}$ Patrick's Day parades were opportunities for Irish Catholics to come together and demonstrate their collective strength. Indeed, large gatherings of Irish Catholics celebrating St Patrick's Day were an imposing indication of the community's presence in a Canada dominated by British identity and Protestant faith.

Yet even among seemingly united communities, consensus could be elusive. Rosalyn Trigger has argued that there has been a tendency in some accounts of St Patrick's Day processions to emphasize conformity and consensus while downplaying the fact that public processions are exercises of power that can achieve the appearance of consensus through the influence of dominant groups or individuals within a community. ${ }^{69}$ This was the case as clerical, elite, and middle-class Irish Catholics used the public display of St Patrick's Day to emphasize values of Victorian respectability to the general population and minimized alternative Irishness. Because Irish Catholic temperance societies were subject to the control and cultural values of individuals primarily from the clergy or elite or middle-classes such as Edward Murphy, John Heney, and Owen McGarvey, they became vehicles through which these self-appointed community leaders disseminated their class vision to the rest of the community. Middle-class Irish Catholics hoping to convince the wider society of Irish Catholics' collective respectability and achieve acceptance into the liberal state were concerned about the real and perceived levels of alcohol consumption among Irish Catholics, particularly among the working classes. Temperance societies functioned to alter the

68 Martin Jones, Rhys Jones, Michael Woods, Mark Whitehead, Deborah Dixon, Matthew Hannah, An Introduction to Political Geography: Space, Place and Politics, Second Edition, (London and New York: Routledge, 2015), 114.

69 Rosalyn Trigger, "Irish Politics on Parade: The Clergy, National Societies, and St Patrick's Day Processions in Nineteenth-century Montreal and Toronto," Histoire Sociale/Social History, Vol. 37, no. 74 (2004): 162163. 
perception of the Irish Catholic community by transforming the real or perceived behaviour of Irish Catholics. The display of respectability and social power attempted to counter images of violence and hard-drinking that had become associated with the Irish Catholic population generally, and on St. Patrick's Day in particular, such as during the 1828 St. Patrick's day celebrations in the Ottawa Valley when "200 men, drunk, dancing, and fighting, degenerated into a riot in which one man was killed and several injured." ${ }^{, 70}$

Some success was achieved as press accounts spoke of order and respectability as St Patrick's Day was reformed according to middle-class values and temperance principles. The True Witness observed with great enthusiasm the festivities in Bytown in 1852. After mass, the St. Patrick's Temperance Society, joined by the other Catholic temperance societies of the vicinity, formed a procession with banners and a band of music. The True Witness glowingly remarked that "good order and regularity prevailed throughout.""71 The celebrations were "highly enthusiastic," remarked the paper, but were nonetheless "characterized by piety, sobriety, and good will as become Irishmen and Canadians. The demon of dissipation was, to all appearances, banished from our midst...This was an undoubted triumph of Father Mathew's idea: the day, thank God, is fast passing away when the whiskey bowl enjoyed a prominent place in the arrangements for the festive gathering of Irishmen. Oh! That that had been so a century ago Irishmen might have now occupied another place in the world's history." 72

Patrick O'Reilly, president of the Royal Tara and Chats Valley St Patrick's Society of Torbolton, which claimed to be the "oldest national society in existence in the rural districts of this section of Canada," reminded other Irish societies that would be joining their 1858

\footnotetext{
Ibid, 19.

True Witness and Catholic Chronicle, (Montreal), 26 March 1852, p. 5, cols. 3-4.

2 Ibid.
} 
St. Patrick's Day procession that "the rules of the society should be strictly adhered to, that no one should indulge in intoxicating liquors."73 The 1862 St. Patrick's Day celebration in Ottawa featured members of the St. Patrick's Temperance Society marching in the large procession. They each displayed on the breast of their coat "a badge of green and white silk having impressed thereon in gold bronze the Harp of Erin and the title of the association." ${ }^{\prime 4}$ At the head of this procession was mounted "the Temperance banner showing a life-sized portrait of Father Mathew, the world-renowned temperance advocate." 75 It was reported that everything passed off in an orderly manner," and that no person "could point out a son of Erin anything the worse of liquor."76

Parade routes took the large and imposing gathering of Irish Catholics down major commercial streets of Montreal and St John's, where they would be seen in all their respectable resplendence by the general population. During the 1866 celebration in Montreal the St. Patrick's Total Abstinence Society met and formed in procession with their temperance bands and banners and made their way to St. Patrick's Hall. There they joined the St. Patrick's Society and proceeded with them to St. Patrick's Church. Following mass, the temperance society joined again with the St. Patrick's Society and accompanied the procession through the city. Their route took them along Bleury, St. Catherine, St. Denis, and Notre Dame streets before arriving at St. Lawrence Hall. ${ }^{77}$ Paying respects along the parade route to civil and religious leaders was a way of asserting both the respectability and Catholicicity of the procession. In St. John's, Newfoundland, the Benevolent Irish Society formed in procession early on the morning of 17 March 1876. They passed along Gower

\footnotetext{
Ottawa Tribune (Ottawa), 27 February 1858, p. 2, col. 7.

Ottawa Tribune (Ottawa), 21 March 1862, p. 2, col. 2.

Ibid.

Ibid.

17 True Witness and Catholic Chronicle, (Montreal), 23 March 1866, p. 4, col. 4.
} 
Street to the Church of St. Patrick at River Head where they paid their respects to the Superintendent and Ladies of the convent, as well as the resident clergyman. They then passed along Water Street and up Cochrane Street to the Governor's House where they paid their respects to His Excellency. From there, the procession headed to the Cathedral where "by the kindness of the Very Reverend Thomas McGrath" they were provided with seats inside the Sanctuary during the "celebration of the most holy sacrifice of mass." "Af After mass, the BIS visited the Episcopal Palace, and then the "merry convents" in the vicinity of the Cathedral. They then returned to their hall where the President of the society thanked them for their attendance and congratulated them on their increased numbers. ${ }^{79}$ Such scenes were repeated across Canada on St. Patrick's Day throughout the late nineteenth century.

The dinner after the parade in which the various Irish societies would gather was another highlight of St Patrick's Day. In some instances these dinners were dry events, owing to the popularity of temperance among organizers of the festivities. The refreshments for the 1853 St. Patrick's Day dinner in Cobourg, for instance, were "principally furnished by the ladies of the congregation, who certainly deserve credit for the deep interest they take in promoting the cause of temperance." ${ }^{80}$ During the 1852 dinner in Montreal, which was the nineteenth annual dinner of the society on St. Patrick's Day, various toasts were made, including one to Father Mathew. ${ }^{81}$ This toast was responded to by the secretary of the temperance society, Edward Murphy. In his address, Murphy "exposed in such a manner the evils of intemperance that we shall be much surprised if he has not obtained fresh converts to the cause. ${ }^{" 82}$ The participation of temperance societies during St. Patrick's Day events served

78 PANL, Benevolent Irish Society, Minute Book, MG-612, entry for 17 March 1876.

79 Ibid.

80 True Witness and Catholic Chronicle, (Montreal), 15 April 1853, p. 5, col. 3.

81 True Witness and Catholic Chronicle, (Montreal), 26 March 1852, p. 5, col. 2.

82 Ibid. 
the two purposes that were fundamental to the middle-class project of identity formation.

First, it displayed the respectability of Irish Catholics to the wider society. Second, St Patrick Day festivities functioned as a guide for behaviour among the Irish Catholics themselves.

The presence of temperance societies at these gatherings reinforced the opinion that behaviour such as the kind that occurred in Bytown in 1828 would not be tolerated by the community.

Acceptance of Catholic respectability by the non-Catholic press is a measure of the success of fusing ethno-religious symbolism with performances of respectability on occasions such as St Patrick's Day. For instance, the Ottawa Citizen noted that the $1861 \mathrm{St}$ Patrick's Day festivities in Ottawa were celebrated in a "pleasant, sober, orderly manner." 83 The next year, the Citizen was even more glowing in its report of the day's festivities, concluding that they had never attended St Patrick's Day festivities which had gone off with better spirit. They noted that throughout the day they had not heard of a single case of intoxication or misconduct, an achievement they viewed as not only creditable to the Irish Catholic community of Ottawa, but to the City of Ottawa in general. ${ }^{84}$ The following year, the Citizen observed that the grand procession of imposing and creditable character consisted mostly of members of the St Patrick's Literary Association, St Patrick's National and Benevolent Society, and the Father Mathew Temperance Society. The most prominent banner that day, the Citizen approvingly noted, was the banner of the Father Mathew Society. The Citizen remarked that the officers of the various societies deserved credit for the excellent decorum displayed by the Irishmen of Ottawa. ${ }^{85}$

The process of fusing of middle-class respectability with Irish ethno-religious

3 Ottawa Citizen (Ottawa), 22 March 1861, p. 4, col. 1.

84 Ottawa Citizen (Ottawa), 22 March 1862, p. 3, col. 6-7.

85 Ottawa Citizen (Ottawa), 21 March 1863, p. 5, col. 2. 
identity appeared, then, to be an effective strategy by the 1860s. Yet such demonstrations of respectability were precarious. A more radical brand of Irish Catholic identity could compromise the process of ethno-religious uplift. David Wilson has argued that there existed a very real class difference between the moderate middle classes who supported constitutional Irish nationalism and the Irish Catholic working-class contingent, where radical nationalists and Fenian leaders commanded significant influence ${ }^{86}$ Michael Cottrell has written about the struggle over control of the St Patrick's Day parades in the 1860s between militant, working-class Irish associations in Toronto, such as the Hibernian Benevolent Society, and the middle-class, moderate, and clerically approved St Patrick's Society. ${ }^{87}$ Cottrell argued that a precursor to the HBS, the Young Men's St Patrick's Association, supplanted the role of the clergy in extra-Catholic festivities and assumed responsibility for organizing the St Patrick's Day celebrations in the late 1850s. Cottrell reasoned that the parades changed dramatically under the auspices of this organization: secular symbols such as shamrocks and harps were more prominent than Catholic iconography, temperance gave way to alcoholic good cheer, and expressions of loyalty to Crown and country gave way to anglophobic speeches. ${ }^{88}$ Cottrell argues that middle classes who supported Church leaders were trying to demonstrate their worthiness as citizens, whereas the working-class radicals used the parades to articulate a discourse of difference, seeking acceptance as they were, rather than integration into Canadian society. ${ }^{89}$

As the working-class militants began to take over St Patrick's Day events in Toronto, the tone of the celebrations transformed. This in turn changed the manner in which the day

86 David A. Wilson, "Introduction," in Irish Nationalism in Canada, edited by David A. Wilson, (Montreal and Kingston: McGill-Queen's University Press), 6.

87 Michael Cottrell, "St. Patrick's Day Parades in Nineteenth-Century Toronto: A Study of Immigrant Adjustment and Elite Control," Histoire sociale/Social History 25.49 (May 1992): 65.

88 Cottrell, "St Patrick's Day Parades," 63.

89 Ibid., 66. 
was covered by the mainstream press. As long as Irish Catholics were using St Patrick's Day to express their ethno-religious identity in ways that conformed to notions of loyalty, the general public was positive about the event. But when they deviated from these accepted norms of behavior, as the militants often did, the reception was negative. This can be observed by tracing the coverage of St Patrick's Day in Toronto's Globe in the 1860s. Festivities organized by the accommodationist and moderate St Patrick's Society were presented in complimentary terms by the Globe. In 1860, it noted that members of the St Patrick's Society celebrated the anniversary of Ireland's Patron Saint in ecumenical fashion with members of the St George and St Andrew's Societies. The first toast that evening was given to "Her Majesty the Queen," and was followed by a rendition of God Save the Queen. The next toast was given to "The Prince Consort, The Prince of Wales, and the members of the Royal Family". Other toasts that evening included ones in honour of the Governor General of Canada, the army and navy of Great Britain, as well as the commercial prosperity of Canada. The St Patrick's Society was made up of elite members of the Irish community in Toronto, and their links to the British Empire and Canadian leaders are evident from the list of attendees assembled for St Patrick's Day celebrations, as well as the activities there that evening. ${ }^{90}$

Yet, respectable behaviour was not enough to win over the Protestant press. Performances of ethno-religious identity had also to conform to, or at least not contradict, political loyalty to the British Empire. In 1861 the HBS scheduled a lecture on St Patrick's Day evening to occur at the same time as the St Patrick's Society's annual dinner. The rivalry between the two Irish Catholic factions split the community throughout the $1860 \mathrm{~s}$. In 1862 a delegation from the Hibernians, which included radical Michael Murphy and

90 Globe (Toronto), 19 March, 1860, p. 2, col. 3. 
newspaper editor Patrick Boyle, sought Archbishop Lynch's consent for a St Patrick's Day procession. Claiming he was ill and unable to meet the gathered individuals, Lynch sent Father Northgraves to meet with Murphy, Boyle, and the rest of the assembled individuals. Lynch had authorized Northgraves to neither oppose nor approve of the projected procession, and to inform them that in deciding whether or not to hold it, they ought to "follow the counsel of their own judgement." ${ }^{91}$ Northgraves did as requested, and reported to Lynch that the Hibernians were satisfied with this. They even considered it a blessing of sorts, but as the day approached Northgraves learned that a number of respectable Irish Catholics of Toronto, referring to themselves as belonging to the "Loyal Irish Society," intended to wait upon Lynch and request that the bishop suppress the intended procession. A deputation made up of some of these "loyal Irishmen," including John O'Donohoe, a prominent Irish Catholic business-owner and politician (whom this study will probe in subsequent chapters for his role in the Catholic League), met with Lynch to state their objections to the proposal of the Hibernians. For the sake of peace, the gathering told Lynch, they hoped he would induce the Hibernians to give up their intention of having a procession. Lynch stated that though he preferred that no procession occur, he did not want to depart from the promise he and Northgraves had given to the Hibernians. O'Donohoe suggested that Lynch hold mass at an hour that would not suit the procession. Lynch rejected the idea, citing a similar act by Archbishop Hughes of New York and the subsequent hard feelings it had caused among the Irish Catholic population there. He did not wish to stir such emotions within his jurisdiction, as Lynch saw no reason to view the Hibernians as an unlawful society. ${ }^{92}$ In the end, Lynch did not side with "respectable" Irish Catholics against Murphy, Boyle, and the other Hibernians and the HBS held their 1862 St Patrick's Day celebrations.

91 ARCAT, LAE 0606, Archbishop Lynch Fonds, Northgraves letter to Lynch.

92 Ibid. 
Yet the Globe reported admiringly on Toronto's 1862 St Patrick's Day. It was noted that members of the HBS all wore the green badges of their society as they formed in procession in front of St Paul's Church to parade through the city streets before listening to mass delivered by Lynch. The Globe remarked that "everyone in the procession conducted himself in an orderly manner, and all looked respectable and well dressed." 93 President of the Society Michael Murphy spoke to the assembled in front of St Paul's Church of the rivalries and divisions between the HBS and "a certain politician from Montreal and would-be leaders in Toronto," a clear reference to Thomas D'Arcy McGee, and noted that he and the Society were glad to be celebrating together on the streets of Toronto that day. Murphy advocated for a temperate celebration that day. He warned people not to celebrate too much, asserting that he hoped the assembled would follow the good advice of Bishop Lynch "and take no liquor in case it might bring disgrace upon them."94 Patrick Boyle followed Murphy, and also spoke on theme of respectability. Boyle noted he was glad to see "that the utmost order and regularity had characterized the whole proceedings." 95 The Globe concluded their report on the day's events by noting that the singing of the "national anthem" "ended St. Patrick's Day, 1862, in the good city of Toronto."96

Clearly at this point the Globe had yet to fully comprehend the factionalism within the Irish community or the politics of the HBS and Murphy and Boyle. By 1863, however, they were more attuned to the situation and as the 1860s wore on, and the radical HBS assumed a more prominent role in the Irish community, St Patrick's Day coverage in the Globe became increasingly unfavorable and hostile. In contrast to the Globe's laudatory report on the its 1862 St Patrick's Day celebrations, their commentary on the HBS's 1863

93 Globe (Toronto), 18 March 1862, p. 2, cols. 5-7.

94 Ibid.

95 Ibid.

96 Ibid. 
festivities was far more subdued and even negative. Their chronicle of the day's events made no mention of Murphy, Lynch, or Northgraves as the featured speakers. Instead, a few lines on "St Patrick's Day" in the "City News" section of the Globe reported on quiet streets, with one or two fights occurring in the afternoon, and a few men being taken into police custody. In 1864 the Globe ramped up the negativity in their St Patrick's Day coverage, reporting on the deleterious effects of the HBS and Murphy's disloyal speeches discussing the unfair treatment of Ireland by the British Empire. ${ }^{97}$

By the mid-1860s, when the threat of a Fenian invasion was seen as increasingly likely, the main issue for Irish Catholics on St Patrick's Day became not sober, masculine respectability but loyalty to Canada and the British Empire. Enunciations of national and imperial loyalty demonstrate the complex negotiations of identity undertaken by Irish Catholics in Canada, situated as they were in both the Atlantic World and the British Empire. Their aims of retaining and furthering their Irish Catholic cultural heritage, while simultaneously participating and advancing in Canadian society were reflected at St Patrick's Day dinners, which included an amalgam of seemingly contradictory toasts including ones to the Queen and royal family, the pope and the Catholic hierarchy and clergy of Canada, the governor general of Canada, the memory of Daniel O'Connell, Father Mathew, and the success of the railroads of Canada. ${ }^{98}$ In the strained sectarian context of the 1860s, the issue of Irish Catholic loyalty intensified.

The Montreal Gazette praised the loyalty demonstrated in the St Patrick's Day festivities in Montreal in 1864 held at the City Concert Hall under the auspices of the St Patrick's Society of that city. One of the notable features pointed out by the Gazette was the

97 Globe (Toronto), 18 March 1864, p. 2, col. 4.

98 True Witness and Catholic Chronicle, (Montreal), 26 March 1852, p. 5, col. 2; 25 March 1853, p. 4, col. 4 and continued on p. 5, col. 1 . 
motto displayed in large letters over the entrance to the hall which read, "Canada the land of our adoption.” In addition to various Irish slogans and flags, the Gazette was also pleased that the Union Jack was hung in the room. ${ }^{99}$ The following year, the Gazette favorably reported on a speech given during the St Patrick's Day celebrations of that year in which it was remarked that now was the time to build an Irish nationality in Canada "alike loyal to the Crown and the land of their birth." The speaker further remarked that while the loyalty of Irishmen had often been questioned, in the procession that day they had a portion of the Prince of Wales Regiment wearing the Queen's livery. No one, therefore, could say that the Irish were not ready to go to the front when required and that when the time did come, Irishmen would not be false. ${ }^{100}$

In the context of the Fenian threat in 1866, the Globe gave short shrift to the St Patrick's Day events in Toronto. Though they made mention of Lynch's sermon in St Michael's Cathedral, they seemed more interested in pointing out the presence of a "dumpy female, of the most enthusiastic stripe" and another woman who, owing to "the excitement, or something else" was very red in the face. While the Ottawa Citizen commented on Lynch's "loyal" address, and the presence of a large number of Protestants and the HBS in the church, it observed that a large number of youth, who were seemingly associated with the HBS and headed by a brass band, did not attend the church as a body as they were refused entry by Lynch. It was also noted that a "strong patrol" would be on the streets of Toronto that evening, "to quell any disturbance which may be created by drunkenness." Because of the Fenian threat, and the reputation of the HBS in Toronto, the press coverage of Toronto's 1866 St Patrick's Day was largely negative, with references to ludicrous incidents, gangs of potentially rowdy youth, and the possibility of violence caused by mass

99 Montreal Gazette (Montreal), 18 March 1864, p. 2, cols. 3-4.

100 Montreal Gazette (Montreal), 18 March 1865, p. 2, cols. 5-7. 
drunkenness. $^{101}$

In contrast, the Gazette, Globe and Citizen all lauded the 1866 St Patrick's Day celebration in Montreal owing to its display of loyalty. The day's events included a stop at St Lawrence Hall where the procession of Irishmen paid their respects to Governor General Lord Monck. In his reply, Monck remarked that he took the procession's show of respect to be evidence of Irish loyalty to their sovereign, of Irish attachments to Canadian institutions, and of Irish protest against the principles of wicked men who would disgrace the name of Irishmen and desecrate St Patrick's Day “by a wanton attack on a peaceful, prosperous, and happy country," a clear reference to the oncoming Fenian menace. ${ }^{102}$ The Citizen extolled the virtues of the speeches that day in Montreal given by Thomas D'Arcy McGee and the presidents of several Irish societies as "national and loyal", and observed that from the manner in which those speeches were received "there is no doubt of the loyalty of the Irishmen of Montreal or that they will be foremost in the ranks to resist invaders from whatever quarters they may come," another unambiguous comment on the Fenian threat. The Gazette approvingly reported on the presence of John A. Macdonald at the evening's concert held under the auspices of the St Patrick's Society, and reported on the brief speech that he gave. Amid loud cheers, Macdonald dwelt upon the "happy and gratifying nature of the day's proceedings."

As the hardline nationalist HBS became more prominent in its role organizing St Patrick's Day celebrations, and expressions of Irish Catholic identity became more bellicose with the rise of the Fenians, the mainstream press coverage increasingly focused on the issue of Irish Catholic loyalty by praising Irish attitudes and behaviours that demonstrated

101 Ottawa Citizen, 19 March 1866, p. 2, col. 1.

102 Montreal Gazette, 19 March 1866, p. 2, cols. 3-5; Globe (Toronto), 19 March 1866, p. 2, cols. 2-3; Ottawa Citizen, 19 March 1866, p. 2, col. 1. 
attachment to, rather than pulling away from, Canada and the British Empire. Most Irish Catholic voluntary associations, save hard-line groups such as the HBS, sought to demonstrate such loyalty.

\section{$\underline{\text { Conclusions }}$}

While many of the middle-class leadership of temperance societies espoused liberal individualist values they did so in part to ameliorate the standing of their collective ethnoreligious group. In presenting this rhetoric, Irish Catholic migrants aimed to integrate and advance in the Canadian economy and society rather than stand isolated from it. The goal of integration and advancement in Canada did not mean that the aspiring middle-classes, any more than the clergy, would blindly follow the dominant Protestant majority in Canada. Strong feelings of ethno-religious sentiment meant that instead of jettisoning their Irish Catholic identity to further their integrationist objectives, they aimed to blend Irish Catholic identity with dominant tropes of liberalism, respectability and self-government. Ambitious Irish Catholics in Canada who joined temperance societies employed norms of middle-class self-government and respectability that would be recognizable to the Protestant majority and adapted these values to Catholic beliefs and Irish nationality.

Through temperance Irish Catholics sought to counter the perception that they were unfit to achieve prominence in society because they could not govern themselves. Part of the performance and display of middle-class respectability was the establishment and maintenance of norms of gendered behaviour, which encompassed ideas about men and women, and related those ideas to Irish Catholic ethno-religious identity. A key part of the masculinity of the Irish Catholic temperance movement was its complementarity with feminine gender norms. Domesticity became the concept around which Catholic masculinity 
and femininity intersected. St Patrick's Day became an occasion to solidify links between the masculine self-governing individual and Irish Catholic identity. A challenge to this respectable, moderate Irish Catholic identity came in the 1860 s as more hardline nationalist organizations like the HBS came to hold prominent roles in Canadian Irish Catholic communities. The rise of the HBS, coupled with the threat of Fenian invasion, led the mainstream press to concentrate on the issue of Irish Catholic loyalty to Canada and the British Empire. As will be shown in the following chapter, loyalty became the main criterion for worthiness for Canadian Irish Catholics in the aftermath of the Fenian Raids of 1866 as they attempted to redefine their image as loyal subjects and emerging liberal citizens all the while maintaining a strong ethno-religious identity separate from mainstream Protestant society. 


\section{Chapter Six: The Fenian Challenge and the Defence of the Liberal Order}

\section{Introduction}

This study has thus far attempted to write the Catholic experience into the broader development of the liberal social order and liberal state by exploring Catholic resistance to state formation in the interest of preserving Catholic values, as well as resistance to the Church's position by liberal Irish Catholics. This chapter carries on from that point by examining the ways in which individual Irish Catholics and some Irish Catholic organizations were in accord with the general tendencies of the liberal state and the liberal social order and challenged the Church's illiberal position, while also being resistant to the state's failure to uphold individual liberties occasioned by anxieties over the Fenian Raids.

Though not the kind of voluntary association that conferred respectability upon its members, the Fenian Brotherhood was nonetheless an important organization within Irish nationalist politics and Irish culture in the nineteenth century. The Irish Republican Brotherhood was formed 17 March 1858 in Dublin, and a parallel organization was formed in New York City in 1859. James Stephens was the founder of the Dublin Fenians, and became the nominal head of the New York organization as well. The Fenians aimed to overthrow English political rule in Ireland and establish an independent Irish state, and in so doing took a physical-force approach to the nationalist cause.

The Fenian Brotherhood was not led by members of the elite or individuals who held middle-class status. Instead it was led by individuals in low-status trades, such as tailors and shoemakers, and those in the lower ranks of white-collar workers such as clerks and teachers. R.V. Comerford noted the Dublin Fenians were made up of individuals employed in these occupations, and records suggest a similar occupational profile for Canadian 
Fenians. ${ }^{1}$ For instance, of the seven alleged Fenians arrested with tavern-owner Michael Murphy at the time of the 1866 Fenian Raids, Michael Moriarty was an employee at the Toronto Savings Bank, Philip Cullen was a carpenter, Daniel Hartnett was a shoemaker, while Michael Stafford, Edward Kelly, Thomas Hanton and Edward Keyes were described by the Evening Times as "either tailors or shoemakers." ${ }^{2}$ Shortly after this round of arrests, shoemaker and member of the Hibernian Benevolent Society Thomas Sheedy was also arrested. ${ }^{3}$ Peter Toner has argued that as time wore on, even after the Raids and into the 1890s, Fenians were coming from "a better cut of society." Irish nationalism, Toner concludes, moved out of pubs and the lives of labourers and had support from at least some of the "Irish social and economic elite." He noted that Fenians who were able to advance in society did so through their own efforts and their ability to raise their own social status. ${ }^{4}$ Thus, though Toner does not say so directly, he implies that it was through the liberal values of individualism and honest work that allowed later Fenians to improve their social status.

In the mid-1860s, Fenians began to agitate for the invasion of Canada to strike at the British Empire. The Fenian attacks on Canada in the 1860s were meant to be the first step in the liberation of Ireland from English rule by diverting the British military and thus increasing the likelihood of a successful rebellion in Ireland. Coming from the United States, Fenians attacked Canada from various locations in the spring of 1866 and again in $1870 .^{5}$

$1 \quad$ R.V. Comerford, The Fenians in Context: Irish Politics and Society, 1848-82, (Dublin, 1998), 101; George Sheppard, "'God Save the Green' Fenianism and Fellowship in Victorian Ontario," Histoire Sociale/Social History, 20 (1987): 135.

2 Irish Canadian, 18 April 1866 p. 4, col. 1; Sheppard, "God Save the Green, 136."

Irish Canadian 18 April 1866, p. 4, col. 1;Sheppard, "God Save the Green," 136.

4 Peter M. Toner, "The Fanatic Heart of the North," in Irish Nationalism in Canada, edited by David A. Wilson, (Montreal and Kingston: McGill-Queen's University Press, 2009), 49.

5 C.P. Stacey, "A Fenian Interlude: The Story of Michael Murphy," Canadian Historical Review 15, no. 2 (June 1934): 133; Hereward Senior, The Last Invasion of Canada: the Fenian Raids, 1866-1870 (Ottawa: Dundurn Press, 1991), 11; Wilson, Irish Nationalism in Canada, 4; Patrick Steward and Bryan P. McGovern, The Fenians: Irish Rebellion in the North Atlantic World (University of Tennessee Press: 2013), xvi. 
Just exactly how many Fenians were in Canada has proven an elusive, though tantalizing, question for Canadian historians. In their look at the history of policing in Canada, Whitaker, Kealey, and Parnaby observe that by the mid-1860s the Fenians had branches in Toronto, St Catharines, Hamilton, London and Kingston. Between 1865 and 1866, Patrick Nolan, a government spy who had infiltrated the Fenian network, reported to John A. Macdonald and Gilbert McMicken (a one-time customs agent, elected member of Legislative assembly, and excise officer, whom Macdonald had hired to establish the new Western Frontier Constabulary) that there were 17 Fenians divisions in Canada West and nine of them in Toronto. ${ }^{6}$ Brian Clarke, however, is skeptical about some of Nolan's claims regarding the number of Fenians in Toronto. Nolan reported that of the 1300 members of the Hibernian Benevolent Society, fully half were sworn Fenians. That there were 650 Fenians in Toronto alone, asserted Clarke, seems highly unlikely. Instead, Clarke argues that there were likely no more than 100 Fenians in Toronto, though that was enough to dominate the Hibernian Benevolent Society. ${ }^{7}$ David Wilson notes that Fenian activity was rife in Montreal as well, where there was a "hard core of dedicated Fenians" who were "working to draw more and more followers into the movement in the 1860s."

Before moving to the question of how many Fenians there were in Canada, one must first define what is meant by "Fenian." Were the 650 Fenians reported by Nolan, or even the 100 estimated by Clarke, all revolutionaries blowing up bombs in the name of a free Ireland? Or were they Fenian, broadly defined? David Wilson advances the latter argument. In his study of Quebec City Fenian Jeremiah Gallagher, Wilson made clear that he was using the

6 Reg Whitaker, Gregory S. Kealey, Andrew Parnaby, Secret Service: Political Policing in Canada From the Fenians to Fortress America, (Toronto: University of Toronto Press, 2012), 22-26.

7 Brian Clarke, Piety and Nationalism: Lay Voluntary Associations and the Creation of an Irish-Catholic Community in Toronto, 1850-1895, (Montreal and Kingston: McGill-Queen's University Press, 1993), 170.

8 David A. Wilson, "The Fenians in Montreal, 1862-1868: Invasion, Intrigue, and Assassination," EireIreland, 34, nos. 13-14, Fall-Winter 2003: 113. 
word Fenian "in a generic sense, to denote anyone who supported or sympathized with the use of physical force to bring about an independent Ireland." "Using this criterion, coupled with meticulous research, Wilson has identified the names of "over a thousand Fenians in British North America." ${ }^{10}$ Wilson's empirical and theoretical work, building upon the research of Peter Toner, has shown that Fenianism was alive in Canada in the 1860s and 1870s.

The spiritedness of the Fenian movement, and the consequent Fenian Raids, however, threatened to undo the work of political and cultural integration that had been accomplished by middle-class Irish Catholics up to that point and undermine any political legitimacy and political capital they had garnered. Brian Clarke argues that the Irish Catholic population expressed ambivalence towards Fenianism, while Peter Toner has argued that there were two Non-Fenian reactions to the events of 1866. The first was a demonstration of loyalty to Canada, and the other was a rise in the popularity of revolutionary nationalism. ${ }^{11}$ Indeed, non-Fenian Irish Catholics were forced to respond to the events of 1866, and did so in divergent ways that ostensibly reflected political divisions between radicals and moderates in the community. Aggressive denunciations came in the form of clerical opposition to the Fenians as a non-Catholic organization, as well as lay protests against Fenian attacks upon Canada, a country many felt gratitude toward owing to the opportunities it provided them. In a piece published in the Canadian Freeman, Thomas D'Arcy McGee urged Irish Catholics to redouble their demonstrations of loyalty to Canada and denounce the Fenian attackers. Many in the community heeded McGee's advice and rejected the radicalism of the Fenian

9 David A. Wilson, "The Fenian World of Jeremiah Gallagher," Canadian Journal of Irish Studies, Volume 39, Volume 1 (2015): 23.

10 Ibid.

11 Peter M. Toner, “The Rise of Irish Nationalism in Canada, 1858-1884," (PhD Diss. National University of Ireland, 1974), ii-iv; Clarke, Piety and Nationalism, 168. 
incarnation of Irish nationalism by demonstrating their loyalty to the Canadian state.

A second reaction to the Raids by non-Fenian Irish Catholics was more combative, and challenged both the moderate Irish nationalists and the loyalist ethos of Canada. This was demonstrated by Patrick Boyle in his position as editor of the Irish Canadian and secretary of the Hibernian Benevolent Society, as well as Irish nationalist J.L.P. O'Hanly in his position as president of the Ottawa-based St. Patrick's Literary Association. Boyle and O'Hanly rejected the position advocated by McGee and instead pointed out inconsistencies in the liberal order by denouncing public suspicions and official abuses of the instruments of state coercion. Their own radical nationalist views were consistent with the liberal individualism that was also at the heart of their support of settler colonialism, as I shall demonstrate. Though that support seemed to advance the power of the British Empire, O'Hanly distinguished Irish victimization from that of less civilized subject peoples and constructed western expansion as a domestic liberal project, much like Boyle's temperance efforts amongst immigrants.

Despite clear differences in the two forms of Irish Catholic response to the Fenian Raids, neither side rejected Irish nationalism wholesale. As this chapter will outline, a range of non-Fenians - from the more radical such as Boyle to the clerically-approved True Witness - harmonized their disavowal of the Fenians attacks with their support for Irish nationalism and independence. They rejected the means of the Fenians, not their ends. Irish Catholic clerical and lay leaders shared the Fenians' opposition to English misrule over Ireland, while also vehemently attacking the wrongheadedness of Fenian attacks upon Canada, a county which was largely, but not wholly, framed by the community as a liberal state in which Irish Catholics had been treated fairly and given opportunities for success. As the next chapter will demonstrate, however, O'Hanly was less sanguine about their 
achievement of political equality. ${ }^{12}$

The Fenians Raids have been explored by historians from a variety of angles.

Hereward Senior explores the Fenian Raids from a military perspective, while Whitaker, Kealey, and Parnaby probe the raids from a state security perspective, focusing on the extent to which the government response to the Raids laid the foundation for an apparatus of state surveillance. ${ }^{13}$ Robert McGee explores mainstream reactions to the Fenian Raids in Toronto, arguing that the general sentiment amongst city citizens was one of panic and agitation. ${ }^{14}$ In a study that focuses on the Irish communities in Buffalo and Toronto between 1867 and 1916, William Jenkins discusses the life of Toronto Fenian Michael Murphy following his escape from a Cornwall jail. Murphy proceeded to Buffalo, where he set up a Fenian faction that was in contact with the Irish Republican Brotherhood in Ireland. ${ }^{15}$ David Wilson explores the Raids by looking at the response of Thomas D'Arcy McGee and his belief that Canadian Irish Catholics had a special obligation to defend Canada from the Fenians. ${ }^{16}$

The first half of the chapter explores the challenge that the Fenian Raids posed to the picture of respectability and acceptance that both the Church and the liberal middle class had gained for Irish Catholics through such avenues as the temperance movement and community-building voluntary associations. This exploration of the varied reactions of middle-class Irish Catholics to the Fenian Raids will be followed by a discussion of the active promotion and participation in colonial practices undertaken by both Patrick Boyle and J.L.P. O'Hanly.

12 An alternative view was presented in J.L.P. O'Hanly, The Political Standing of Irish Catholics, which will be discussed in the following chapter.

13 Hereward Senior, The Last Invasion of Canada: the Fenian Raids, 1866-1870, (Ottawa: Dundurn Press, 1991), 11; Whitaker, Parnaby, Kealy, Secret Service, 22-26.

14 Robert McGee, Fenianism: The Toronto Reaction, 1858-1868, (Lulu Press, 2014), 419.

15 William Jenkins, Between Raid and Rebellion: The Irish in Buffalo and Toronto, 1867-1916 (Montreal \& Kingston: McGill-Queen's University Press, 2013), 183.

16 David A. Wilson, Thomas D'Arcy McGee, Volume 2, The Extreme Moderate, 1857-1868 (Montreal \& Kingston: McGill-Queen's University Press, 2011), 281. 
The second part of this chapter will illustrate the decidedly liberal yet colonialist actions of Boyle and O'Hanly. The Fenian Brotherhood was not the type of association explored by Greer and Radforth, McNairn, or Ferry. Nevertheless, individuals like Boyle and O'Hanly, who were not afraid to come to the Fenians' defence, played a part in the expansion of the Canadian state and thus by implication of the British Empire, through their association of liberal middle-class values with the promotion of settler colonialism.

\section{The Fenian Challenge to the Irish Place in Canada's Liberal Order}

The Canadian press had been informing the public about the Fenian menace prior to 1866. Fenian threats began to make headlines in Toronto in 1864 on the eve of Guy Fawkes Day (the second key anniversary in the Orange calendar) when members of the Hibernian Benevolent Society (HBS) threateningly walked the streets after dark armed with pistols, swords, and other weapons. ${ }^{17}$ The HBS, a voluntary association that shared with the Fenians a desire for Irish independence, was formed in response to Toronto's 1858 St Patrick's Day riot during which Irish Catholic Matthew Sheedy was killed by Orangemen. Because of their revolutionary overtones the HBS was often condemned by the wider society as occurred in the aftermath of the 1864 Guy Fawkes Day episode. Their involvement garnered widespread condemnation from the press and led to wide-spread fears of a Fenian fifth column. Unsurprisingly, then, the Canadian press continued to assail the Fenians during the 1866 Fenian Raids. The Montreal Gazette, which at the time represented a loyal and conservative British identity and demonstrated antipathy toward Irish Catholic nationalism, reprinted an article from the Chicago Tribune that referred to the Fenian leaders as being "without

17 Globe (Toronto), 8 November 1864, p. 2, cols. 4-5; Michael Cottrell, "Green and Orange in MidNineteenth-Century Toronto: The Guy Fawkes Day Episode of 1864," Canadian Journal of Irish Studies 19, no. 1 (July 1993): 12. 
brains" and their followers "without characters."18 Another reprinted article, this time from the London Times, referred to the Fenians of Ireland as being "confined to the lowest and least responsible class of the population." 19 The Gazette thus urged the Canadian government to take a firm hand against the Fenian threat. ${ }^{20}$ The physical-force Fenian movement also forced middle-class Irish Catholics to contend with press reports and popular conceptions that cast doubt upon the loyalty of their ethno-religious community in general. As a result, many felt it necessary to convey to the wider society, which felt as the Montreal Gazette did, that they did not support the actions of either the Fenians or their sympathizers. Failure to do so might have awakened sectarian animosities and set back the gains of the recent past just when Irish Catholics were beginning to find social acceptance. The clergy denounced the Fenians because it was not a Church-approved organization, while employing unquestionably liberal rhetoric in editorializing for the political independence of Ireland and denouncing the Fenians for endangering Canadian self-government. The middle-class lay response commented on how Fenianism threatened the liberal social order within which Irish Catholics had been gaining political capital.

Catholic clerics presented the Fenians as a secret society not sanctioned by the Catholic Church. In June 1866 Bishop of Kingston Edward John Horan sent a circular to the clergy of that diocese instructing them to make it clear to their parishioners the duties which they owed to the government under which they lived and "earnestly exhort them to fulfil those duties with alacrity and zeal." ${ }^{21}$ Horan referred to the Fenians as "a horde of lawless men, who turn a deaf ear to the warning voice of the Church" and said in response that it was

18 Montreal Gazette, 25 April 1866, p. 4, cols. 2-3.

19 Montreal Gazette, 28 April 1866, p. 2, cols. 3-4.

20 For more on mainstream Canadian press reaction, especially from The Globe, see C.P. Stacey, "A Fenian Interlude: The Story of Michael Murphy," Canadian Historical Review, 15, no. 2, (June 1934): 136.

21 Canadian Freeman (Toronto), 28 June 1866, p. 2, col. 6. 
the duty of "every good citizen and true Catholic to stand by the government and support it at any cost that may be required."22 Horan's denunciation of the Fenians as an Irish Catholic organization without clerical endorsement recalls clerical opposition to Irish Catholic voluntary associations unconnected with the Catholic hierarchy. Indeed, it was a secret oathbound organization and the Vatican ruled membership in the Fenian Brotherhood incompatible with adherence to the Roman Catholic Church. In the 1860s the Church in both Britain and North America refused to give Fenians access to sacraments and priests were instructed not to absolve members of the organization. Furthermore, as Oliver Rafferty observes, the Holy See decreed that priests should use their influence privately in the confessional to warn individuals of the moral dangers associated with Fenianism. ${ }^{23}$ Be it publicly or privately, then, the Church officially opposed membership in the Fenian organization.

This was laid plain by the Canadian Freeman when it noted that as far back as 1864 both the paper and the Catholic hierarchy had "discussed at some length the question of Fenianism, with the view of proving to our readers that the organization was not calculated to commend itself to the good sense and approbation of our countrymen."24 Given that the Freeman was an organ of the Catholic clergy in Toronto it was not surprising that one of the major criticisms it levied against the Fenians was that it was "an organization, mainly composed of Catholics, that lacked the sanction and blessing of the Church" and an organization that "spurned the authority and interference of God's anointed ministers." 25 On the point of the relationship between Catholicism and Irish societies, the Freeman argued

22 Ibid.

23 Oliver Rafferty, "Fenianism in North America in the 1860s: The Problems for Church and State," History 84.274 (April 1999): 259.

24 Canadian Freeman (Toronto), 10 May 1866, p. 2, cols. 1-2.

25 Ibid. 
that "any and every movement undertaken by Irishmen for the ostensible purpose of ameliorating the condition of their common country can never succeed if the Hierarchy and Priesthood, the press and the majority of the substantial residents of Ireland refuse to...support it." 26 The editorial concluded that the Fenian organization "had no claim upon the confidence or sympathy of Irishmen." ${ }^{27}$ The key point made here was that the Fenian Brotherhood could not speak for the Irish Catholic community because it was not approved by, or affiliated with, the Catholic Church.

For the respectable middle classes, the raids and reaction to the raids provided an opportunity to disassociate themselves from the Fenian variety of nationalism and demonstrate their acceptable liberal values. Irish Catholic clergy and the respectable middle classes who professed their loyalty to Canada framed themselves as spokespeople for the community distinct from Fenian leaders who attempted to do the same. Yet this distinction was not as strict as it may appear. Rejecting Fenian nationalism did not mean rejecting Irish nationalism. In spurning the actions of the Fenians, Irish Catholics bemoaned not the ends but rather the means of the organization. They did not jettison the cause of Irish nationalism or independence; rather they attempted to legitimize their own brand of "respectable" Irish nationalism in opposition to the threatening Fenian variety. It was hoped that by taking such an approach their form of respectable Irish nationalism would not only survive the Fenian interlude but come to occupy a place of good standing in Canadian political culture.

In "The Duty of the Hour," an article published in the 7 June 1866 edition of the clerical organ the Canadian Freeman, Thomas D' Arcy McGee wrote that the ringleaders of the Fenian raids were not Irishmen and did not represent Ireland. By flying the Irish colours the Fenians "have devolved upon the Irish a special obligation of taking a determined and 26 Ibid.

27 Ibid. 
conspicuous stand in defence of this country."28 The Fenians were fighting for the cause of Irish independence and McGee argued it was incumbent upon the Irish to show loyalty to Canada by aggressively refuting the type of nationalism promulgated by the movement. McGee enjoined the Irish Catholics of Canada to "let no class to have it hereafter to say that you failed your country in the hour of danger." ${ }^{29}$ McGee was cognizant that the wrath of Canadian society might come down hard on those whom the Fenians purported to represent. Many within the lay middle-class Irish Catholic community complied with McGee's injunction to go above and beyond the call of duty to demonstrate the worth of their ethnoreligious community during this crisis point. Several arguments were made, and one contention was that, given how well Canada had treated incoming Irish migrants, attacks upon Canada were unfair. The True Witness, which was the clerical organ in Montreal, argued that the multitude of Irish Catholics in Canada "received nothing but kindness and hospitality and true Christian charity." 30 The paper admonished that the Fenians were "forgetting the hospitable reception which their starving, plague-stricken countrymen have always been received in Canada." 31

The True Witness wasted little time in separating the Fenian cause from their own version of Irish nationalism. The paper remarked that the tactics of the Fenian raiders were not "the way to make Ireland respected or her cause popular with honest men." "32 To the True Witness, the revolutionary and invasive actions of the Fenians placed the entire cause of Irish independence in a negative light. They noted that the Fenians would have enlisted the "sympathies of the entire world on behalf of Ireland, as a country oppressed, and held by

\footnotetext{
Canadian Freeman (Toronto), 7 June 1866, p. 2, col. 2.

Ibid.

True Witness and Catholic Chronicle (Montreal), 27 April 1866, p. 4, col. 3.

Ibid.

32 Ibid.
} 
brute force in subjection to an alien rule and yet they do their best to render that sympathy impossible" by inflicting the same wrong on Canada. ${ }^{33}$ The aspirations, the editorial continued, "of the Irish after freedom for themselves, after the right to govern themselves and to reform the abuses of which their country has long been the victim are not only legitimate but are high and holy aspirations if proceeding from a genuine love of right." 34 The True Witness argued that their physical force approach made it "impossible to sympathize with Fenians, in their avowed readiness to inflict upon Canada, had they the power to do so, the very wrong which they maintain England has inflicted upon Ireland by depriving her of her national independence." ${ }^{35}$ This inconsistency in Fenian thought, the editorial continued, placed the Fenians in a losing position: "they do not perceive that, by their refusal to recognize the right of self-government in others...they furnish the enemies of Ireland with the strongest arguments against Irish nationality and Irish independence." ${ }^{36}$ The notion of self-government presented here by the True Witness, the substance of the liberal project in Canada two decades earlier, would become a cornerstone in rhetoric linking Canadian dominion status with the campaign for Irish Home Rule, the subject of Chapter Seven. Clerical organs advanced liberal arguments both about self- government in favour of Irish independence and to denounce Fenian attacks on responsible government in Canada. Yet there were practical limits to clerical use of liberal rhetoric, as will appear later in their willingness to accept the state's coercive suspension of individual liberties in defence of order.

33 Ibid.

4 Ibid.

35 True Witness and Catholic Chronicle (Montreal), 2 November 1866, p. 4, cols 3-4.

36 Ibid. 
The Radical Nationalist Response in Defence of a Liberal Order

Another segment of the Irish Catholic population resisted calls to profess loyalty and instead focused on the political rights of Catholics to be innocent until proven guilty and to enjoy the protections of the British constitution such as habeas corpus, which affords an individual accused of a crime the right to challenge their detention before a judge. It is a cornerstone of legal liberalism, in which all are seen as innocent until proven guilty. Those who responded in this way, notably J.L.P. O'Hanly and Patrick Boyle, felt that the anxiety regarding national security was being exploited by anti-Irish and anti-Catholic elements. ${ }^{37}$ E.A. Heaman has argued that the right to due process was privileged by nineteenth-century liberals ${ }^{38}$ and was thus a key part of the liberal order. When that right was taken away, O'Hanly employed the language of liberalism to critique the illiberal move on the part of the state. He argued that habeas corpus was the "palladium of individual liberty" and that its suspension led to a "reign of terror" with surveillance by the secret service, home invasions, and interception of correspondence..$^{39} \mathrm{O}$ Hanly's and Boyle's position regarding the unjust treatment of Catholics and the suspension of habeas corpus advanced the view that Catholics were excluded from the liberal order and they challenged the state's unwillingness to preserve individual liberties in time of crisis.

Fears of unjust mass arrests were heightened even before the Canadian Assembly voted in the Habeas Corpus Suspension Act in June 1866. Some of the "duty to loyalty" Irish Catholics supported the suspension yet were nonetheless mindful of the potential for arbitrary arrests. ${ }^{40}$ While they signed a petition to be forwarded to the government to have

37 John Lawrence Power O'Hanly, The Political Standing of Irish Catholics in Canada, A Critical Analysis of its Causes, With Suggestions for its Amelioration, CIHM 23746, 44.

38 E.A. Heaman, A Short History of the State in Canada, (Toronto: University of Toronto Press, 2015), 84.

39 O'Hanly, The Political Standing of Irish Catholics, 44.

40 Canadian Freeman (Toronto), 14 June 1866, p. 2, col. 3. 
habeas corpus suspended, the Canadian Freeman was quick to note that should the government consent to the step they were sure that ample provision would be made to guard against arbitrary arrests:

If the suspension of the Habeas Corpus would leave our co-religionists at the tender mercy of a class of men who have been displaying their truculence and bigotry within the past few days we sincerely trust Parliament will have the good sense and liberality to reject the application. ${ }^{41}$

While the Freeman expressed concern over the potential for sectarian animosity resulting from the suspension of habeas corpus they nonetheless remained sanguine that the Irish Catholics of Canada would receive ample government protection. The clerical organ at this uncertain point therefore reflected ultramontanist illiberalism in supporting established authority as they advocated for the temporary removal of due process and the right to be considered innocent until proven guilty.

Others in the Irish Catholic community were less optimistic and framed their anxieties as a defence of liberal values and the legal practice of due process. There was therefore a clear division between the conservative Catholic Church and the liberal laity. Fear and anger related to the potential for capricious arrests in the wake of the raids was demonstrated most publicly in the pages of the Irish Canadian. This might have been expected. After all, the Irish Canadian was widely regarded as the organ of the HBS, as most of the stockholders, printers, and editors of the Irish Canadian were members of the HBS. Patrick Boyle, for instance, was secretary of the HBS in addition to his role as editor of the Irish Canadian. Certainly one of the reasons why the Irish Canadian focused so intently on potential legal repercussions against Irish Catholics resulted from the arrest of

${ }^{41}$ Canadian Freeman (Toronto), 7 June 1866, p. 2, col. 5. 
Michael Murphy. Murphy, along with Boyle and John Mulvey, was one of the provisional directors of the Irish Canadian. Murphy was also the president of the HBS. There had long been allegations that the HBS was a Fenian front organization and these claims were ramped up after the constitution of the society was made public in 1865 and showed a paramilitarylike organization structure. While neither Murphy nor Boyle fully denounced Fenianism during the 1860s, they did deny any links between the HBS, the Irish Canadian, and Fenianism.

Whitaker, Kealey, and Parnaby argue that John A. Macdonald originated the political policing procedures that would eventually lead to the arrest of Murphy and other suspected Fenians. They assert that Macdonald, as Attorney General in Upper Canada and later as Dominion leader, "developed the mechanisms necessary to gather intelligence in recognition of personal, national, and imperial interests." 42 This represents the roots of what Franca Iacovetta branded the 1950s "national insecurity state" that defended a class, gender, and race-based exclusionary version of middle-class ideals. It demonstrates also the enduring limitations to liberalism that persisted in the Canadian liberal order. ${ }^{43}$ Whitaker notes that this surveillance apparatus was first established to deal with the Fenian threats of the 1860s. Murphy and other suspected Fenians had been under government surveillance since about 1865. Patrick Nolan had infiltrated Fenian circles in Canada, and had been giving information about their activities to Macdonald and Gilbert McMicken. ${ }^{44}$ Murphy was arrested along with seven other alleged Fenians in Cornwall in 1866 as a consequence of this surveillance. It was thought they had money and weapons in their possession, along with

42 Whitaker, Parnaby, Kealey, Secret Service, 36.

43 See Franca Iacovetta, Gatekeepers: Reshaping Immigrant Lives in Cold War Canada, (Toronto: Between the Lines Press, 2006), especially Chapter Ten, "Guarding the Nation's Security: On the Lookout for Femmes Fatales, Scam Artists, and Spies."

44 Clarke, Piety and Nationalism, 169. 
tickets to Boston, and it was suspected they were to join the Fenian force assembled at Portland, Maine in order to strike at New Brunswick.

Following Murphy's arrest, Boyle chose to emphasize this injustice rather than deal with issues related to strains of Irish nationalism, the legitimacy of the Fenian organization within the Irish community, or injunctions to the Irish community to show increased loyalty in these tense times. He argued that the arrests represented a betrayal of legal liberalism. "We cannot imagine," an editorial argued, "why they were even interfered with, as it has not been shown that they were guilty of any breach of law, and were merely travelling as ordinary citizens would and in the usual way." 45 The Irish Canadian asserted the men did not act guiltily either before, during, or after their arrest. The eight purchased their tickets openly, and did not resist when arrested aboard the train. They were, the Irish Canadian argued, "not conscious of having done anything wrong." 46 The arrest of Murphy and the others was viewed by Boyle and the Irish Canadian as a consequence of their ethnoreligious identity, rather than their ties to the Fenian organization, and was therefore a result of Orange bigotry and a subversion of the liberal order and the legal protections which E.A. Heaman has argued were so important to nineteenth-century liberals. ${ }^{47}$

The manner in which the arrest was planned and carried out, along with the individuals involved, came in for severe censure from the Irish Canadian. It was noted that railway official C.J. Brydges telegraphed the names of eight suspected Fenians aboard the eastward-bound train to Attorney General for Canada East George-Étienne Cartier. ${ }^{48}$ Cartier

Irish Canadian (Toronto), 18 April 1866, p. 4, col. 1.

46 Ibid.

47 Heaman, A Short History, 84.

48 In his article on Murphy, Stacey notes that Brydges was on the train. But the key point here is less what actually happened than how the Irish Canadian, as a representation of the more hardline Irish nationalist component in Canada, reacted to the events of 1866 and what this tells us about this perspective. Stacey, "A Fenian Interlude," 148. 
then telegraphed the mayor of Cornwall, Dr. William Cox Allen, that a party of eight suspected Fenians were aboard this train headed to Montreal and advised Allen to arrest and detain the men. Allen rounded up approximately 300 volunteers to "surround the railway station with loaded guns and fixed bayonets." 49 After its arrival in Cornwall the voluntary force boarded the railway cars, asked for the passengers who were headed to Boston, and proceeded to arrest Murphy and the other men.

The Irish Canadian censured the conduct of Brydges, not Murphy or the other men arrested. Calling the action of Brydges "not at all creditable to the manager of the Grand Trunk Railway," the editorial maintained that Brydges acted as a "government spy and detective." ${ }^{50}$ The editorial argued that the Grand Trunk demonstrated a close connection with the government with its "officials and employees making special pimps and informers of themselves." ${ }^{51}$ They concluded by stating that they felt the charges could not be proven against the accused and hoped in the near future to "be able to tell our readers that the prisoners have been fully and unconditionally discharged." 52 Boyle here was making a case for due process against a reliance on informers like Brydges. By arguing for the rights of the liberal British constitution and against arbitrary measures, Boyle was defending both the liberal order and the Fenians against what he saw as the wider society's illiberal response to the raids.

The paper's support for Murphy and the other Cornwall prisoners would continue. Moving from their attack on the "pimp and informer" Brydges, the Irish Canadian in subsequent weeks would assail the legal team who were prosecuting the alleged Fenians. "We have never," an editorial of 25 April 1866 asserted, "seen such a mockery of law and

49 Irish Canadian (Toronto), 18 April 1866, p. 4, col. 2.

50 Ibid., p. 4, col. 1.

51 Ibid.

52 Ibid., p. 4, col. 2. 
such a total disregard for justice." "In fact," the blustering article continued, "such a blundering piece of business we thought to be an impossibility at the hands of men who profess to be learned in the law and who are looked upon as the dispensers of justice, without fear or favour." 54 They maintained that mayor Allen, who was the principal actor on behalf of the government, was a "bitter Orange partisan, and in the selection of magistrates gave special invitations to his Orange confreres in office to be present at the examinations...passing over Catholic members of the bench." 55 The Irish Canadian asserted that the legal proceedings were unprofessional and conducted on partisan and sectarian lines, lacking in due process. Having read the evidence against the prisoners the Irish Canadian felt "surprised that they have not long since been discharged unconditionally" and contended that it was "on account of their religious persuasion that they are subjected to such treatment." $" 56$

Criticism regarding the treatment the Cornwall prisoners were receiving continued to emanate from the pages of the Irish Canadian. In the 2 May 1866 edition an editorial maintained that the prisoners were doomed to an indefinite imprisonment "not because they have been found guilty of any charge implicating them in any overt act of treason against British supremacy in Canada or elsewhere" but because "the authorities remand them from time to time, under the pretence of being able to produce evidence, which they say will convict one of them at least of the high crime." ${ }^{, 57}$ The Irish Canadian argued the evidence was not forthcoming because it did not exist. They continued to oppose the nature of their arrest, arguing that from the outset the men were arrested "on the flimsiest pretences which

\footnotetext{
Irish Canadian (Toronto), 25 April 1866, p. 4, col. 4.

Ibid.

Ibid.

Ibid., p. 4, col. 5.

Irish Canadian (Toronto), 2 May 1866, p. 4, col. 1.
} 
is possible to conceive; and a supposition of being participants in a warlike undertaking, the only color for surmising which consisted in the fact of their journeying toward an American city. ${ }^{\prime 58}$ They maintained that despite the fact the government had been preparing evidence for months and engaged in all manners of activities to bring charges to bear upon these men, "they are not able to bring home to any person the clear proof of complicity with treason" because Murphy and his cohorts were innocent. ${ }^{59}$

For his part, Macdonald was aware of the unease caused by the suspension of habeas corpus. In a letter to the crown attorney at Kingston, Macdonald said that he regretted to find that arrests had been made throughout the country "on the mere suspicion" of Fenianism and asserted that such arrests were to be avoided and discouraged in every way. ${ }^{60} \mathrm{He}$ maintained that no arrests "should be made on mere suspicion, nor without information on oath, stating specific facts sufficient to establish a case of Treason..."${ }^{{ }^{11}}$ Macdonald explained that his concern in this matter stemmed from the "great deal of uneasiness among the Irish Roman Catholic population in consequence of some of these hasty and ill-judged arrests." ${ }^{{ }^{6} 2}$ Macdonald also believed that mass arrests of Fenians was not necessarily the most practical way to rid Canada of the Fenian menace. "Even," Macdonald wrote, "if a party were known positively to belong to the Fenian organization it is not desirable that he should be arrested, as there is every reason to hope that late events will break up the whole of this illegal organization in Canada." ${ }^{93}$

Whether Macdonald actually felt this way or was using this as an opportunity to

58 Ibid.

59 Ibid; Murphy would escape the Cornwall prison and head to the United States where he died in Buffalo in 1868.

${ }_{60}$ Canadian Freeman (Toronto), 5 July 1866, p. 2, col. 7; Irish Canadian (Toronto), 6 July 1866, p.5, col. 1.

${ }^{61}$ Ibid.

${ }^{62}$ Ibid.

63 Ibid. 
score political points among the maligned Irish Catholic population is not clear. Moreover, there was consideration given to how the treatment of Irish Catholics in the post-Raid period would impact the popularity of Fenianism. Brian Jenkins notes that while the Canadian press wanted "the speedy trial and exemplary punishment" of the captured Fenians, the possibility of executions alarmed Britain's government. ${ }^{64}$ Lord Stanley, the foreign secretary, explained to Lord Carnarvon, secretary of state for the colonies, that any "unusual severity" in the punishments would have a negative effect on the already taut relationship between Britain and the colonies. ${ }^{65}$ The possibility of trials without juries, argued the high-ranking British officials, offended basic principles of British justice and threatened to further inflame Fenian passions in North America and abroad. Whitaker, Parnaby, and Kealey note that Macdonald was pressured by these British officials to exercise restraint in the absence of habeas corpus. Brian Jenkins argues that Macdonald's fear that arbitrary arrests would drive the Catholic Irish into the arms of the Fenians "ensured that this form of harassment was quickly discontinued. ${ }^{66}$ Indeed, Macdonald agreed to move cautiously and hold regular civilian trials, rather than military courts martial. ${ }^{67}$

Boyle remained angered by the treatment of the Irish Catholics in the wake of the raids. The Irish Canadian was treading a dangerous path by taking such a truculent approach to the events of 1866 and the wider society soon became critical of the paper's views. Boyle and the Irish Canadian certainly did themselves no favours by defending the Cornwall prisoners, nor did they then gain public sympathy when they printed a manifesto from the

64 Brian Jenkins, The Fenian Problem: Insurgency and Terrorism in a Liberal State, 1858-1874, (Montreal \& Kingston: McGill-Queen's University Press, 2008), 63.

65 Ibid.

66 Jenkins, The Fenian Problem, 63.

67 Whitaker, Parnaby, Kealey, Secret Service, 29. Between October 1866 and January 1867, 57 alleged Fenians were brought to trial and 22 were sentenced to hang. The hanging sentences were converted to 20 years hard labour in the Kingston Penitentiary. Macdonald wrote that this gesture would prove to the Roman Catholics of Ontario that he "consulted their feelings in the matter." 
Canadian branch of the Fenian Brotherhood. This document read like one of the paper's defences of Murphy and the other prisoners, stating that "the Government of Canada has wantonly and treacherously caused the arrest and imprisonment of a number of our fellowcitizens, seized them without charges. ${ }^{" 68}$ The manifesto asserted that prior to this act by the government, the Fenian Brotherhood of Canada had "steadfastly and honestly opposed any attempt at the invasion" of Canada. However, they took the arrest of the individuals at Cornwall as

a challenge and a defiance, and will act accordingly...whenever the head centre gives his consent, we shall be ready to avenge the insult, and root out from American soil the last vestige of the tyranny to which, ninety years ago, the 'thirteen colonies' gave the first blow, and, aided by our French Canadian fellow-citizens, replace it with the emblem of an independent sovereignty or the starry flag of that nation which is the last hope of freedom, republicanism, and Ireland. ${ }^{69}$

Canadian press outlets had long lashed out at the Irish Canadian for adhering to a radical nationalist perspective and this intensified during the period of the raids. The Belleville Intelligencer argued that the Irish Canadian ought to be shut down. The Intelligencer was owned by future Prime Minister of Canada Mackenzie Bowell. Bowell was also a leading figure in the Orange Order, having joined the organization in 1842 . From 1870 to 1878 Bowell was Grand Master of the lodge in Canada and in 1876 he was elected president of the Order's Imperial Triennial Council in Londonderry. ${ }^{70}$ It is no surprise that a paper owned by the Orangeman Bowell would take such a harsh stand against the Fenians and the editorial stance of the Irish Canadian. Further, such a perspective demonstrates the hostility Irish Catholics faced at this juncture with respect to the nationalist question. The

68 Irish Canadian (Toronto), 25 April 1866, p.5, col. 3.

${ }^{69}$ Ibid.

70 P.B. Waite, "BOWELL, Sir MACKENZIE," in Dictionary of Canadian Biography, vol. 14, University of Toronto Press/Universite Laval, 2003-, accessed June 18 2015, http://www.biographi.ca/en/bio/bowell_mackenzie_14.html. 
Intelligencer reasoned that during times of relative normalcy and peace it might be acceptable to "allow these hot-headed treason mongers to boil over occasionally, but in times like these, when the country is sacrificing so much to preserve the peace" it was objectionable to allow "the men who are aiding and abetting her (Canada's) enemies, and openly publishing their shame to the world" to continue their activities. ${ }^{71}$ It was no time, the Intelligencer maintained, "to trifle with treason, nor parry with traitors."72 This was not the only instance of the loyal Canadian press referring to the Irish Canadian using terms such as traitors and treasonous. The Brantford Courier also joined in on the attack. Calling the Irish Canadian a "wretched journal" and "the Fenian organ of Canada," the Courier claimed that it "does not hesitate to give utterances to the most treasonable statements." ${ }^{13}$ Like the Intelligencer, the Courier argued that the Irish Canadian ought to be shut down on grounds of treason and called upon the government to "snuff it out at once." "74

Despite public censure the Irish Canadian continued to print what many viewed as inflammatory editorials and letters in defence of the alleged Fenians and the liberal order. Irish Catholics expressed hostility toward their so-called duty to demonstrate loyalty as they felt it unfair that the burden of proof fell upon them to show that they were not associated with the Fenian movement. One letter writer who identified himself only as "A Canadian Catholic" from Peterborough, admonished McGee for forgetting that "there are duties and obligations devolving upon other classes of our citizens besides your countrymen and coreligionists." ${ }^{" 75}$ The letter continued by detailing a history of "petty persecutions, of a social, political, and public character, which for years have been indulged in, not only against the

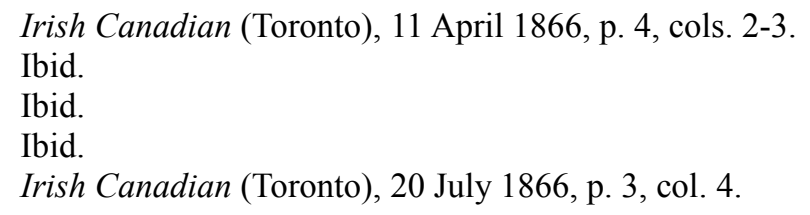


Irish of a certain class, but specially against Catholics in general in Upper Canada." ${ }^{96}$ This history of persecution, A Canadian Catholic continued, explained why young Catholics have not "cheerily and promptly swelled the ranks of our brave volunteer force in greater numbers" to fight the Fenian menace. ${ }^{77}$

From a similar viewpoint, "A Subscriber" told the story of a "display of gross bigotry" that took place in Bolton, Canada West in July of $1866 .^{78}$ The event in question revolved around the creation of a subscription for a dinner in honour of the Bolton Village Company of Volunteer Militia. Lists were soon sent around the neighbourhood for individuals to contribute. The letter writer asserted that while Catholics were permitted to donate, "the privilege of allowing Catholics to sit at table with her Majesty's loyal Orange subjects was an offence not to be permitted...so the Volunteers, to the number of from five to ten stoutly refused to go to dinner if any $\mathrm{d}-\mathrm{d}$ Papist Fenians were permitted to eat or sit at table with them.."79 Though the letter writer was quick to point out that the conduct of the volunteers in question was seen as distasteful even by "the great majority of Protestants," he nevertheless went on to assert that this example was "only one of the many instances where the Volunteers of the Province have taken advantage of their positions to insult their Catholic fellow subjects, who are equally as loyal as they are, notwithstanding their pretensions." ${ }^{\prime \prime 0} \mathrm{~A}$ Subscriber expressed the belief held by more than a few Canadian Irish Catholics that it would do no good for their co-religionists and fellow-countrymen to demonstrate loyalty to Canada because many Canadians would not even afford them such an opportunity.

Such analysis indicated that the mistrust and ill-treatment of Irish Catholics in

\footnotetext{
Ibid.

Ibid.

Ibid., p. 5, col. 3.

Ibid.

Ib Ibid.
} 
Canada fostered resentment among the Irish Catholic population. Yet there undoubtedly existed diversity within the Irish experience and Irish attitudes across Canada. In the recent edition of the Canadian Catholic Historical Association's journal Historical Studies, which focused on the Irish Catholic experience in Halifax, Katherine Crooks notes that proimperial sentiment reigned in the garrison town. ${ }^{81}$ Owing to their social and financial interest in seeing the continued success of the Empire, Irish Haligonians were eager to form local militia units in response to British anxieties over the possibility of conflict with France in the 1850s and 1860s. ${ }^{82}$ Two militia units, the Halifax Rifles and the Irish Volunteer Rifles ${ }^{83}$ were raised by prominent Irishmen Thomas E. Kenny, who was the "son of the richest and most powerful of Halifax's Irish Catholic merchants," ${ }^{84}$ and William Condon, who was a leading civil servant and former president of the Charitable Irish Society in Halifax. ${ }^{85}$

While militia support did exist amongst the Irish, Desmond Morton has noted that the succession of British officers who led the Canadian Militia to 1904 imposed British military traditions on the militia. This may have left some Irish Catholics, especially the two letterwriters to the Irish Canadian, feeling excluded and discriminated against. ${ }^{86}$ Feelings of Irish exclusion were outlined by J.L.P. O'Hanly, who believed that the Upper Canadian Militia Bill of 1855 was intended to put "arms into the hands of the Orangeman of Upper Canada". ${ }^{87}$ The bill allowed for the formation of an active militia and 5000 volunteers were armed,

81 Katherine Crooks, "The Quest for Respectability: The Charitable Irish Society in Victorian Halifax," Canadian Catholic Historical Association, Occasional Paper 81 (2015): 194.

82 Ibid., 188.

83 Ibid.

84 David A. Sutherland, "KENNY, THOMAS EDWARD,” in Dictionary of Canadian Biography, vol. 13, University of Toronto/Université Laval, 2003-, accessed April 7, 2016, http://www.biographi.ca/en/bio/kenny_thomas_edward_13E.html.

85 J. Murray Beck, Joseph Howe Volume II: The Briton Become- Canadian, 1848-1873, (Montreal and Kingston: McGill-Queen's University Press, 1984), 110.

86 For the British traditions in the Canadian militia, see Desmond Morton, Ministers and Generals: Politics and the Canadian Militia, 1868-1904, (Toronto: University of Toronto Press, 1971).

87 O'Hanly, Political Standing of Irish Catholics in Canada, 33. 
trained, and paid for their service. O'Hanly argued that just after the bill was passed, "Orange companies were being organized on all sides." When Irish Catholics requested to the government to form their own militia company, they were not even given "the common courtesy of a reply to their application." ${ }^{88}$

During the Fenian Raids Irish Catholics proposed forming their own military companies. This led to the emergence of Protestant anxieties and real discrimination occurred. Robert McGee notes that the wider society bristled at the suggestion of the Irish Catholic population being armed and trained at the expense of the government. ${ }^{89}$ The Canadian government did in fact refuse to allow the Irish Catholic population to enrol. ${ }^{90}$ Thomas D'Arcy McGee criticized attempts in Upper Canada to exclude Roman Catholics from volunteer and drill associations. ${ }^{91}$ McGee had formed an Irish militia unit in Montreal in the winter of 1861-62, ${ }^{92}$ and was now angered that his fellow-countrymen in Upper Canada were unable to demonstrate their loyalty to Canada during this tumultuous time. As the letter-writers to the Irish Canadian and the words of O'Hanly and McGee suggest, the Irish Catholic population was under suspicion and not welcomed into the Upper Canadian militia during the raids, despite the community's desire to defend Canada against the Fenians.

By presenting the conundrum in which Irish Catholics found themselves with respect

88 Ibid.

89 McGee, Fenianism, 242.

90 ARCAT, Lynch Papers, Lynch to Sir Ētiene Tachē, November 1864.

91 David A. Wilson, Thomas D'Arcy McGee Volume 2: The Extreme Moderate, 1857-1868, (Montreal and Kingston: McGill-Queen's University Press, 2011), 281.

92 Ibid., 129. Wilson placed the formation of McGee's militia unit within the context of divisions within Montreal's Irish community between moderates, like McGee, and radicals, like Bernard Devlin, the lawyer, politician, many-time president of the St Patrick's Society, and suspected Fenian, who raised his own militia unit in Montreal in 1856. Seemingly, then, there were two Irish Catholic militia units in Montreal in the early 1860s, McGee's moderate one and Devlin's radical one. J.-C. Bonenfant, "DEVLIN, BERNARD," in Dictionary of Canadian Biography, vol. 10, University of Toronto/Université Laval, 2003-, accessed April 7, 2016,http://www.biographi.ca/en/bio/devlin_bernard_10E.html. 
to the question of loyalty and belonging, these letters represent one aspect of the Irish Catholic response to the Fenian Raids. Writers to the Irish Canadian, along with Boyle in his position as editor of the publication and member of the HBS, aggressively queried the rationale behind the mass arrests of Irish Catholics, the suspension of habeas corpus, and the atmosphere of suspicion under which they found themselves whether they had Fenian ties or not. They viewed the suspension of habeas corpus as a betrayal of legal liberalism and indicative of their exclusion from the Canadian liberal order.

\section{$\underline{\text { Radical Irish Nationalism and the Liberal Order }}$}

A similarly combative posture was adopted in the wake of the Fenian Raids by John Lawrence Power O'Hanly during his tenure as president of the St Patrick's Literary Association in Ottawa. O'Hanly was born in Waterford, Ireland on 24 June 1827 . He immigrated to Canada in 1846. Following his arrival in the port city of Quebec, O'Hanly was employed as a clerk for the lumber merchant Robert Ackert. He later taught school in the town of Buckingham. In March 1851 O'Hanly moved to Aylmer where he became indentured to Joseph A. Mason, provincial land surveyor for Lower Canada, and J.J. Roney, provincial land surveyor for both Lower and Upper Canada. Upon completion of his apprenticeship O'Hanly obtained his diploma as land surveyor for Lower Canada in May 1853 and Upper Canada in July 1854. In August 1854 O'Hanly moved to Bytown, soon to be Ottawa. He then embarked on a distinguished career as a civil engineer for the Canadian Pacific Railway, as well as a land surveyor for the Department of the Interior mapping provincial boundaries and laying out Indian Reserves. Alongside his professional resume, O'Hanly was an ardent supporter of Irish nationalism and actively involved in Irish Catholic 
voluntary associations in Ottawa. Peter Toner has called O'Hanly a Fenian. ${ }^{93}$ I would suggest that his Fenian credentials are thin, especially without clearer reference from Toner, who made this remark in the context of lamenting the lack of Fenian records in Canada. He noted the existence of O'Hanly's papers, but said that they shed no light on his Fenianism. Given the role O'Hanly played in the 1882 Home Rule Resolutions, his agreement that they ought to be moderated in order to achieve the widest possible breadth of support, ${ }^{94}$ the fact that he was never arrested, and that his papers do not tell us anything about whether he was a Fenian or not, I would exercise caution before casting O'Hanly as a Fenian. Nevertheless, O'Hanly was a nationalist — on the radical end of the spectrum to be sure and, moreover, a nationalist on the level of Patrick Boyle, though with far fewer links to Fenianism than Boyle-who not only attacked British imperial rule, but also the role of the Catholic hierarchy in the Irish nationalist movement and Irish Catholics whom he felt betrayed the nationalist cause through their accommodationist positions. ${ }^{95}$

Like Boyle, O'Hanly openly railed against the treatment of Irish Catholics during the raids and rejected McGee's “duty to loyalty” position. O'Hanly and McGee had a history of animosity with regard to Fenianism within the Canadian Irish Catholic community and on issues of Irish nationalism in general. O'Hanly outlined his antipathy toward McGee's actions during the Fenian tumult of 1866, when McGee accused members of Montreal's St Patrick's Society of having Fenian ties. O'Hanly was angered not only by McGee's assertions but by the timing of his accusations. "Be it not forgotten," O'Hanly wrote, "that he (McGee) played this nefarious role at a time of great excitement, at a time of acute exasperation...when all passions of the worst elements of society were in open hostility to his

93 Toner, "The Fanatic Heart of the North," 49.

94 This topic will be explored in Chapter Eight.

95 LAC, O'Hanly Papers, MG 29, B11, Volume 34, File 2, "Biography of J.L.P. O'Hanly.” 
own countrymen, always a despised minority." 96 He believed McGee was "the biggest rascal that ever crossed the Atlantic Ocean," one of the most prominent of the "innumerable breed of traitors which mother Erin has hopelessly brought forth," and referred to him as the "informer general" of the Canadian government for what he viewed as treasonable actions toward his fellow countrymen. ${ }^{97} \mathrm{O}^{\prime}$ Hanly's hostility towards McGee's views on the nationalist question demonstrates his own aggressive approach to the issue, as did his actions during the 1867 St Patrick's Day procession in Ottawa.

In his role as president of the St Patrick's Literary Association O'Hanly was involved in the planning of this controversial procession. An early planning meeting for the parade was marred by a division within the organization between supporters of the various strains of Irish nationalism. At this meeting, according to a report in the Canadian Freeman, "a pretty numerous and rather unusual increase" of the society's membership took place. ${ }^{98}$ As was usual the election of officers of the SPLA took place on the first Tuesday in March. Under a by-law of the organization new members were not allowed to vote in these elections. The correspondent for the Freeman observed that upon being made aware of this rule at the election meeting a "very enthusiastic" young man charged at the minute book in an attempt to seize it. This proved unsuccessful and the man was dragged off the platform, but not before a general scuffle ensued which made the continuation of the elections impossible that evening. It was believed and reported, though never confirmed, that these new members had ties to the Fenian Brotherhood. Their alleged plan was to elect officers to the executive committee of the organization who they felt would promote their more radical nationalism. Owing to the disturbances they caused a second night of election voting was held where a

96 LAC, O'Hanly Papers, Volume 18, File 9, "Status of Irish Catholics, Darcy McGee of Nonsavory Memory." 97 Ibid.

98 LAC, O'Hanly Papers, MG 29, B11, Volume 26, "Press Clippings_-Irish," File 13. 
similar occurrence was reported to have taken place. At that point Father Michael Molloy, the spiritual director of the SPLA and of the Irish Catholic temperance movement in Ottawa, took the floor to announce that he had been authorized by Bishop Bruno Guigues of Ottawa to inform the members present that if this trouble could not be resolved then the St. Patrick's Day procession would be censured by diocesan administration. This brought the "enthusiastic" young man back to the stage to proclaim that the SPLA had conspired with the clergy to "kill the procession." ${ }^{99}$ He thanked God that he had made friends at a distance from whom he had borrowed two banners that he would carry all by himself on St. Patrick's Day should he have to. The two banners he referred to were the Sunburst banner and a flag associated with noted Irish nationalist Robert Emmet which was emblazoned with the nationalist slogan "Erin Go Bragh."

Both these flags were linked to the Fenian movement. Stephen A. Brighton asserts that the sunburst, along with the Celtic harp and shamrocks, was a common symbol of the United Irishmen and the Fenian Brotherhood. ${ }^{100}$ The sunburst flag has its origins in Celtic mythology, as it was used by the Fianna, who were warrior bands. The Fianna referred to themselves as Gal Greine, which means sunburst. Yet in more modern articulations, the flag itself was reappropriated by the Fenians in 1858 , to demonstrate their own place in Irish history. While prior to the emergence of the Fenians, the sunburst was a common sight at Irish celebrations, such as the 1857 St Patrick's Day celebrations in Montreal, by this point the sunburst banner had become a de facto Fenian symbol. ${ }^{101}$ Following the "enthusiastic" young man's outburst, the "hot-heads" at the meeting backed down in the wake of Molloy's threat. It was agreed by members of the SPLA, at the behest of the Catholic bishop of

99 Ibid.

100 Stephen A. Brighton, Historical Archaeology of the Irish Diaspora: A Transnational Approach, (University of Tennessee Press: Knoxville, 2009), 78.

${ }_{101}$ Montreal Gazette, 18 March 1857, p. 2, col. 4. 
Ottawa, that no revolutionary flags would fly on St. Patrick's Day.

Notwithstanding the Bishop's request, the Sunburst banner was unfurled during that parade, causing mass chaos. Upon seeing this flag the Chief Marshall of the parade "turned his horse homewards and left the procession." ${ }^{102}$ A few members of the SPLA forcibly pulled the flag down and re-started the stalled procession. As one might imagine this scene raised eyebrows in the city and across the province. The flag had significance because of its links with the Fenians, and in the midst of the Fenian Raids of 1866, which had created anxiety among the population, the loyalty of Irish Catholics to Canada was openly questioned. The issue of loyalty was played out in the press and it was O'Hanly's loyalty that was interrogated the most. Letters to various Ottawa press outlets came fast and furious in response to the 1867 St. Patrick's Day incident. The main line of contention related to the "hot-heads" at the SPLA meetings and their claim of having "friends" from a distance. These friends, it was reported in the Freeman, were "Fenian roughs" brought in on the train the morning of the procession from Ogdensburg, New York with the aim of raising the banner in question.

Echoing the criticisms levelled against Boyle and the Irish Canadian, people who wrote letters to the press signed "Londonderry," "True Briton," "A British Canadian," and "Young Canada," names that all declared a Protestant identity, expressed unease over the degree to which O'Hanly, and Irish Catholics in general, were loyal to the crown. "Londonderry" asserted that the Sunburst was the flag of enemies of Queen and Country and thus wanted to know whether these gentlemen were in sympathy with the robbers and pirates who murdered their fellow-citizens last June, referring to the Fenian raids. "True Briton" argued that all "loyal" men must look with suspicion upon processions in which the

${ }^{102}$ LAC, O'Hanly Papers, MG 29, B11, Volume 26, "Press Clippings_-Irish,” File 13. 
emblems of avowed enemies are paraded. The writer reasoned that O'Hanly should have known that the raising of this flag would not demonstrate their loyalty at this particular time in the estimation of their fellow citizens. "A British Canadian" echoed these sentiments, maintaining that at a time when treason was boldly manifested in portions of the British dominions such actions were unwise. These calls were taken a step further by a group of "Loyal inhabitants of the capital of Canada" who signed a petition addressed to Ottawa mayor Robert Lyon requesting that he take steps to find out whether there existed in Ottawa men whose aim it was to encourage and assist the Fenian Brotherhood in the invasion of the province and the subversion of Her Majesty's Government. ${ }^{103}$

O'Hanly responded to these accusations of treason in a letter published in the 21 March 1867 edition of the Ottawa Citizen. He first contested the claim that the Sunburst banner was brought to Ottawa by Fenian roughs from Ogdensburg. Rather, O'Hanly asserted, the banner originated in Ottawa. The material of the banner was purchased in Ottawa, the design was prepared by a mechanic from Ottawa, it was sewn in a Convent in Ottawa by the Sisters of Charity, and it belonged to the St. Patrick's Society of the Township of Gloucester. According to O'Hanly this was a sufficient guarantee that the banner was neither revolutionary nor seditious in design. Further, O'Hanly questioned the contention that the flag itself was treasonous or revolutionary. If the Fenians used it, he maintained, that did not make it a Fenian flag. The Sunburst was the old national flag of Ireland and was meant to symbolize the banner under which the fathers of Irishmen in Canada fought the common enemies of the sister isles. O'Hanly refused to denounce the unfurling of the banner, instead framing the banner in a way that would be more acceptable to the British Protestant majority. ${ }^{104}$ While the Sunburst flag had been associated with ancient Ireland, as O'Hanly 103 Ibid. 104 Ibid. 
correctly suggests, by 1866 it had become sufficiently associated with the Fenian movement and revolutionary nationalism that O'Hanly's defence of its use appears either cynical or ignorant. It is likely, though, that O'Hanly was not ignorant or disingenuous of the contemporary uses of the Sunburst banner and was attempting to justify its presence at the parade. O'Hanly was cognizant of the social context within which he found himself. His views on Irish nationalism veered toward the radical. However, the demographics of Canada at the time, as well as the turmoil that ensued in the aftermath of the Fenian raids of 1866 , meant than any expression of Irish nationalism in Canada at that juncture had tempered and spliced with noises of national loyalty in order to placate wider society's anxiety concerning Irish nationalist politics. Despite Toner's assertion that O'Hanly was a Fenian, and the fact that the Fenian flags flew over St Patrick's Day in Ottawa, none of the letters which attacked O'Hanly and the Fenian cause referred to O'Hanly as a Fenian. Still, O'Hanly's refusal to distance himself from the emblems and symbols of the Fenian Brotherhood indicates his intractable and radical attitude toward Irish nationalist politics.

\section{$\underline{\text { Patrick Boyle, Peter O'Leary: Settler Colonialism in the Liberal Order }}$}

The Irish nationalism of Boyle and O'Hanly existed simultaneously and without inconsistency with their participation in and promotion of Canadian settler colonialism. Recognizing this fact is part of a reconsideration of the participation of Irish Catholics in various types of colonialism. Rather than understanding Irish Catholics as functioning solely outside of, or in opposition to, the British Empire and colonial practices, we must probe the role of Irish Catholics in global systems of colonialism and imperialism and aim to destabilize the binary between Irish nationalism and imperialism. In exploring careers of Irishmen in the Indian Civil Service, S.B. Cook argued that the most common Irish response 
to British rule was support, which he characterized as "a broad category encompassing conscious and active collaboration as well as acquiesence in laws, values, and social structures that were partly shaped by British hegemony." 105 Donald Akenson has likewise argued, "Whether they settled in the British or American empire the members of the Irish diaspora were an integral part of the nineteenth- and twentieth-century tidal waves of European imperialism...The Irish participated energetically, efficiently, and enthusiastically in all these processes and they were very well rewarded for doing so." ${ }^{106}$ More recently, S. Karly Kehoe explored the careers of Irish surgeons in the British Royal Navy in the midnineteenth century. Kehoe focused specifically on two Catholic brothers from Belfast, Richard and Frederick McClement, and some of their Irish medical colleagues and concluded that the pragmatic loyalism these Irish surgeons displayed ensured a stronger relationship between Ireland's middle class and the British state. ${ }^{107}$

Boyle and O'Hanly can be placed among this group of Irish colonizers across the Empire, their radical Irish nationalism notwithstanding. And though neither Boyle nor O'Hanly saw imposing a liberal regime on the Canadian west as advancing the cause of British imperialism, and would likely have bristled at the suggestion of any complicity in the imperial project, both these fervent Irish nationalists certainly played a role in the expansion of the British Empire through the medium of the Canadian state. O'Hanly's and Boyle's

${ }^{105}$ S.B. Cook, "The Irish Raj: Social Origins and Careers of Irishmen in the Indian Civil Service, 1855-1914," Journal of Social History 20 (1987): 507-508.

${ }^{106}$ Donald Akenson, The Irish Diaspora: A Primer, (Toronto: P.D. Meany Company Inc. Publishers, 1993), 151. Cook and Akenson are only two of a number of scholars who have called for increased attention to the role of the Irish in the extension of the British Empire. See also Stephen Howe, Ireland and Empire: Colonial Legacies in Irish History and Culture (Oxford: Oxford University Press, 2000); Pauline Collombier-Lakeman, "Ireland and Empire: The Ambivalence of Irish Constitutional Nationalism," Radical History Review 104 (Spring 2009): 57. Graeme Morton, David A. Wilson, Irish and Scottish Encounters With Indigenous Peoples: Canada, the United States, New Zealand, and Australia, (Montreal; Kingston: McGill-Queen's University Press, 2014).

107 S. Karly Kehoe, “Accessing Empire: Irish Surgeons and the Royal Navy, 1840-1880," Social History of Medicine 26.2 (2013): 204. 
settler colonialism was consistent with their advocacy of the liberal state. While both were motivated by a commitment to the Irish Catholic community, they were also driven by a belief in middle-class values and liberalism. Their enthusiasm for colonialism was a function of a belief in advancing the liberal order with its emphasis on the liberal values of individualism, independence, and self-improvement, a cause they viewed as being independent from the British imperial project.

Throughout the 1870s, Boyle and the Irish Canadian promoted western colonization schemes with the aim of attracting Irish Catholics to the North-West, particularly through the publication of Peter O'Leary's writings. ${ }^{108}$ O'Leary was born in Ireland and moved to England with his family when he was six. His father was a farm labourer who moved the family close to London to take up a similar occupation. O'Leary himself worked in similar pursuits, until he moved to London and obtained work as a paviour's labourer, eventually rising to the rank of street mason and paviour. O'Leary joined the trade union movement in London, as he supported the movement's emphasis on "self-reliance, unity and cohesion," traits which he found to have been "beneficial to the toiling classes." ${ }^{109}$ As an Irish member of the Agricultural Labourer's Union, O'Leary was selected by that organization in 1873 as a delegate to Ireland with the objectives of forming a union and reporting on the general conditions of Irish labourers. Distraught over the poor conditions of the labourers in Ireland, the Agricultural Labourer's Union proposed to investigate the possibility of organizing a large emigration of Irish labourers to North America. With this goal in mind, the president of the Union, Joseph Arch, visited Canada and the United States late in 1873. To supplement and expand upon the information collected by Arch, as well as what was included in John

${ }^{108}$ For secondary literature on Peter O'Leary see, Dirk Hoerder, Creating Societies: Immigrant Lives in Canada, (Montreal \& Kingston: McGill-Queen's University Press, 1999), 67.

109 Peter O'Leary, Travels and Experiences in Canada, The Red River Territory, and the United States, (London: John B. Day Printer and Publisher, 1877), 2. 
Francis Maguire's The Irish in America, it was decided to send a workingman to North America "to get as much information as possible for the emigrating classes." ${ }^{110}$ O'Leary was selected for this mission. During his trip, O'Leary asserted that he saw "American civilization in every phase, from the most refined in large cities, to that of the Indian tribes inhabiting the region north of Lake Superior, or the fertile plains of Manitoba." ${ }^{111}$ O'Leary supported an emigration plan that would see thousands of Irish labourers settled in North America, and in 1877 he published Travels and Experiences in Canada, The Red River Territory, and the United States which detailed his findings. ${ }^{112}$

In the hope of enticing Catholics from Ireland to emigrate to the newly developing Canadian territory, the Irish Catholic community supported O'Leary's plan. In 1874 James Mulligan, a wealthy Irishman from Fort Garry, deposited $£ 100$ sterling in the Merchant's Bank in Winnipeg in the name of trustees to be appointed by O' Leary. The men he chose as trustees for Mulligan's funds were Boyle, Montreal's Thomas Ryan, Robert McManus of Winnipeg, and Mulligan himself. The Irish Emigrant Fund was to be "applied to assist Irish emigrants to take up land under the auspices of the Society represented by Mr. O'Leary."113 Boyle deemed this emigration project important to aid potential incoming Irish in their transition and adjustment to Canadian life. "We who boast of our love for Ireland," Boyle remarked, "have been noisy enough in our self-laudation; we have coaxed ourselves into the belief that we are far ahead of our neighbours of the English and Scotch races in the matter

10 Ibid, 5 .

111 Ibid, 6 .

112 Journals of the House of Commons of the Dominion of Canada From the $7^{\text {th }}$ February to the $10^{\text {th }}$ May, 1878 (MacLean, Roger: Ottawa, 1878), A2-7. Whether O'Leary's work in promoting immigration to Canada from Ireland was successful is unclear. Library and Archives Canada asserts that the Canadian and Ontario governments signed agreements with O'Leary's union and led to the immigration of several thousand individuals, but it is not clear as to how many were Irish. https://www.collectionscanada.gc.ca/immigrants/021017-2232.02-e.html, Accessed 27 January 2016.

113 Irish Canadian (Toronto), 2 September 1874, p.4, col. 1; Irish Canadian (Toronto), 7 October 1874 p.4, col. 5; O'Leary Travels and Experiences, vi. 
of love for kith and kin...but however rosy and agreeable all this may appear in theory, unfortunately for us it will not allay the hunger of a single empty stomach." ${ }^{114}$ Boyle thus called upon the Irish in Canada to come up with something "practical" to aid their fellow countrymen in their emigration to Canada. Noting that few would have large sums of money to contribute to the fund, he also asserted that there were few who would "begrudge a dollar to aid the stranger Irish in quest of that denied them at home - the means of an honest and independent livelihood." 115

The Irish Emigrant Fund would have been quite useless without Irish emigrants, however, and in order to attract such individuals, upon his return O'Leary lectured on the prospects of Manitoba for potential emigrants. In these lectures, O'Leary described the "particulars as to the soil and climate of Manitoba, and the advantages offered the enterprising settler by the Prairie provinces." 116 Boyle noted that with so many different and conflicting accounts of Manitoba, it was good to have O'Leary's "unbiased opinion of the capabilities and resources of Canada as they have appeared to him." ${ }^{117}$ These reports would form the basis of his 1877 Travels and Experiences.

O'Leary's reports on conditions in Manitoba were a common feature in the pages of the Irish Canadian through the mid-1870s. One report remarked that O'Leary found Manitoba "admirably adapted to settlement," save for exceptions here and there. ${ }^{118}$ Near the Pembina Mountains, settlement locations were being taken up quickly. He had chosen three townships near the mountains, which he intended to "recommend to his people as a desirable location in which to erect their new homes." 119 He reported that wherever the soil was not the

${ }_{114}$ Irish Canadian (Toronto), 2 September 1874, p.4, col. 1

115 Ibid.

116 Ibid.

117 Ibid.

${ }_{118}$ Irish Canadian (Toronto), 23 September 1874, p. 4, col. 2.

119 Ibid. 
best, it was made up for by an "abundance of wood and an inexhaustible supply of excellent water." ${ }^{\prime 20} \mathrm{O}$ 'Leary was laudatory in his description of the scenery in and around the city of Winnipeg. "No penman," he remarked, "however brilliant, can describe the splendour of the scenery...dense forests, huge rocks, and almost boundless lakes. ${ }^{" 121}$ He noted that the country from Thunder Bay to the north-west angle of the Lake of the Woods was "uninhabited, except by a few Indians and the men on the portages." ${ }^{122}$ The land from Fort Francis to the Lake of the Woods was "very rich," and vegetation was "luxuriant, at once showing the fertility of the soil." ${ }^{123}$ There was a Hudson's Bay post at Fort Francis, and O'Leary opined that "if ever it is touched by a railway, it will become an important place as there is good air, good land, good water, a noble river, and plenty of timber." ${ }^{124} \mathrm{O}$ 'Leary also aimed to present a positive picture of Winnipeg. He asserted that in eastern Canada, people thought Winnipeg was governed by "pistol rule." 125 In fact, he countered, "life and property are as secure in Winnipeg as in any place I have ever visited at home or abroad." ${ }^{126}$ Winnipeg, a city of about 3,500 people, was undergoing rapid development. During the past month he observed "not less than twenty houses" being built. In addition, there were two Catholic churches, and a Protestant church. ${ }^{127}$ The Catholic church was the seat of Rev. Taché, the Archbishop of St. Boniface, whose palace, along with the cathedral, school, and nunnery, were all in the same enclosure. O' Leary was impressed with the overall climate during his prairie journey, and noted that "it may be a shade warmer than the climate of England." 28

Those who have experienced a Winnipeg winter will wonder what region of England

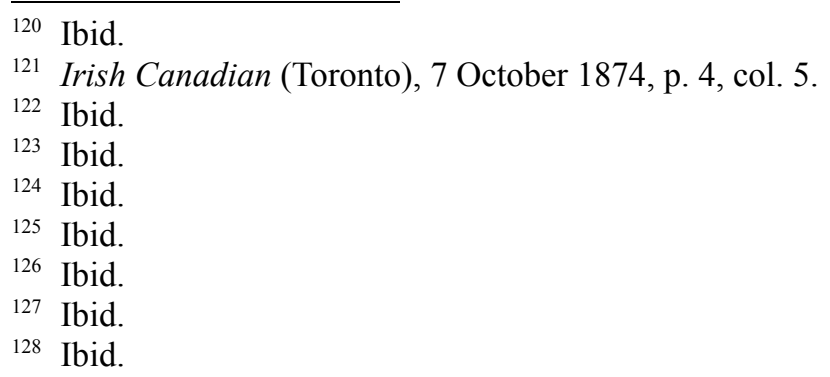


O'Leary was referring to. O'Leary was perhaps overly glowing in his report. It was his mandate to present this Canadian region in an attractive manner to entice Irish agriculturalists to settle in the region. However, not all of O'Leary's reports glowed so positively. He was far more sanguine with respect to the prospects of homesteaders on "fertile soil," than urban labourers. In fact, he asserted that he "would not advise laborers to come to Manitoba." ${ }^{129} \mathrm{He}$ maintained that a man coming to settle "ought to have some capital to enable him to make a beginning on the land," and with energy and attention to work, O'Leary had "no hesitation in saying that he will do well." ${ }^{130}$ In speaking directly to the Irish, he proclaimed, "if some of the labourers and small struggling farmers of Ireland were out here, they would soon turn the Province into a garden, and a competence for themselves and their children." ${ }^{131}$ O'Leary concluded his report by stating that he was pleased he visited the North-West, and he felt that within a few years, it would be the home to a large population. He asserted that the North-West was filled with "great natural resources that only simply require developing, and railway communication is the first step in that direction." 132

Through his position as editor of the Irish Canadian, Boyle espoused the values of the emerging liberal order by supporting this and other attempts to foster individual independence and advance Irish Catholics. ${ }^{133}$ Individual and family independence was a goal of the liberal order and the independence that could be garnered by leaving towns and cities

129 Ibid., p.4, col.6.

130 Ibid.

131 Ibid.

132 Ibid.

133 Boyle also supported the New Ireland colonization plan in the early 1880s, which aimed to have Irish migrants settle in Manitoba. This plan was also supported by John Costigan and Archbishop Lynch, but was never realized. "Improvident Emigrants: John Joseph Lynch and Irish Immigration to British North America, 1860-88," in Creed and Culture: The Place of English-Speaking Catholics in Canadian Society, 1750-1930, ed. Terrence Murphy and Gerald Stortz (Montreal and Kingston: McGill-Queen's University Press, 1993), 177. 
was a major feature in the rhetoric of this and other colonization schemes. In 1876, for instance, a colonization scheme was established by Bishop Jean-Francois Jamot of Peterborough to establish settlers in the free lands in the area north of Lake Rosseau and Muskoka. ${ }^{134}$ Jamot had made his winter home in Bracebridge, which was situated on the Muskoka River, a "gate-way leading into the tract open to free settlement."135 There, readers of the Irish Canadian were informed, the Bishop or one of his clergy was always to be found, ready to relay the "best information as to the qualities of the land the condition of the roads, the means of transportation, and all the particulars necessary for the guidance of a new-comer determined to cut out independence on the free lands like a man of pluck and sense.""136 "Why will young, industrious, Irish Canadians," it was asked, "remain in our towns and cities earning the indifferent bread of dependence," when such opportunities as this existed. ${ }^{137}$ Not only were such individuals "exposed to want" in urban centres, they were also exposed to the "moral danger" of idleness that comes with such a condition. Indeed, this moral danger, it was argued, struck Irish Catholic men "down but too often from the manliness of sturdy industry into the degradation of sin and shame."138 Interestingly, despite the clearly gendered language in this injunction, the responsibility of actually moving to these free lands was placed equally upon Irish Catholic men and women:

If an Irish Catholic has even one or two hundred dollars to give his daughter as a dower, or if a sensible daughter of his has saved by her industry that sum of money, let him or her not bestow it with her hand on a young fellow content to drag her into the miserable condition of existence open to them in such places as Toronto. Let them on the contrary make the bestowal subject to the condition that with that perfectly sufficient sum he go to make for her, like a true and faithful man, a permanent means

134 Alan Stillar, "JAMOT. JEAN-FRANCOIS," in Dictionary of Canadian Biography, vol. 11, University of Toronto/Universite Laval, 2003-, accessed June 18, 2015, http://www.biographi.ca/en/bio/jamot_jean_francois_11E.html

${ }_{135}$ Irish Canadian (Toronto), 27 September 1876, p. 5, col 2 and p. 4, col. 3.

136 Ibid.

137 Ibid.

138 Ibid. 
of comfort in a homestead of their own on the fine soils of Muskoka. ${ }^{139}$

Jamot's settlement project addressed the goal of economic independence for Irish Catholic men but under the guidance of the Catholic Church and through the valorization of rural life. The promotion of such colonization plans represent a Catholic revision of a state project in ways that asserted Catholic values and a measure of Catholic control. The Church insinuated itself in ways that would not directly challenge the state but would facilitate a Catholic path of economic advancement.

In addition to examining and reporting on the economic benefits of settling in the North-West, Boyle also emphasized the moral imperatives of such an undertaking. Indeed, the liberal project of moral reformation was closely linked to settler colonialism, and was espoused by O'Leary and Boyle in their injunctions to their Irish audience. These moral imperatives imposed the familiar boundary between city and country, with the former being a place of sin, idleness, and dependence and the latter representing comfort, manliness, and independence. There were, however, opportunities for sin even in the country. Intemperance, it was warned, could lead a potential settler to both economic and moral ruin. O'Leary, like Boyle, was an ardent temperance supporter. Boyle, an officeholder in a Toronto Catholic temperance society, at one point noted that while O'Leary was charged with looking after the physical interests of potential settlers to the North-West, he was not unmindful of moral obligations. O'Leary lived in London, England, and this, according to Boyle "afforded him the opportunity of learning that the only drawback to the happiness and prosperity of his fellow-countrymen in England is intemperance." ${ }^{140}$ In rhetoric remarkably similar to that which had denounced alcohol consumption during St Patrick's Day celebrations, Boyle

${ }_{139}$ Ibid.

${ }^{140}$ Irish Canadian (Toronto), 23 September 1874, p.4, col. 2. 
linked the success of Irish settlers in the Canadian North-West to abstinence. If the Irishman, Boyle opined, "could be induced to drop whiskey and attend to his business in a clearheaded, sober manner, there is no doubt whatever that he would be able to maintain his place in the social scale respectably and comfortably." 141 Boyle continued that the desire for reforming the habits of "our erring people is not as wide-spread as could be wished," but it was fortunate that O'Leary, who had such influence among the working classes, was a strong advocate of total abstinence. ${ }^{142}$ Here, Boyle coupled the working classes with excessive alcohol consumption. Temperance was a class-based project of moral reformation, indicative of the middle-class liberal values with which settler colonialism was imbued by Boyle and other Irish Catholic expansionists.

O'Leary lectured on temperance during his time in Manitoba. On one such occasion in Winnipeg he was introduced by Chief Justice Edmund Burke Wood. Wood, the son of an Irish-American farmer who immigrated to the Niagara District after the War of 1812, was a lawyer, judge, and politician who became the Chief Justice of Manitoba in 1874. In introducing O'Leary, Wood remarked all evidence that could be summed up went to show that drink was "ruinous both physically and mentally, and that it was the duty of society to stamp it out."143 O' Leary elaborated on the theme of alcohol being mentally and physically harmful, and extended his discussion to note that this harm was felt by all classes of society, but "especially the working classes." ${ }^{144} \mathrm{He}$ asserted that "jails, asylums and workhouses...were monuments of rum and its consequences." 145 Through the Irish Canadian, Boyle heaped praise on O'Leary for his stance on the demon rum, saying that O' Leary

$\begin{array}{ll}141 & \text { Ibid. } \\ 142 & \text { Ibid. } \\ 143 & \text { Ibid. } \\ 144 & \text { Ibid. } \\ 145 & \text { Ibid. }\end{array}$ 
"deserves well for his laudable efforts in the redemption of the tippler and the drunkard. This sin it is that pulls down its victim to the lowest depths of misery and infamy. How blind the man who cannot appreciate the blessings pouring down from a temperate life."146 Boyle asserted that "it is the solemn duty of all God-fearing men to stretch forth the hand to their fallen fellow-creatures and snatch them from destruction. This is what Mr. O'Leary, among his other onerous duties, is endeavouring to do - and for this he commends himself to our lasting gratitude."147

\section{J.L.P. O'Hanly: Settler Colonialism and the Liberal Order}

Like Boyle, O'Hanly also promoted the colonization of western Canada following Confederation in 1867. He worked as a land surveyor for the Dominion government, and two of his major projects consisted of surveying land in the Canadian west, including the Canadian Pacific Railway Survey, which began in 1871 under Sanford Fleming as Engineerin-Chief. ${ }^{148}$ Mapping this land was important in the nation-building process for the newly established Canadian state to demonstrate its sovereignty in domestic affairs. Knowing and controlling the land through scientific cartography was a crucial component of this project of national rule. Such a project aimed to project dominant Western European meanings onto the land and in the process marginalize and subordinate indigenous meanings of the same land. ${ }^{149}$ In addition to the nation-building aspects of O'Hanly's work, land surveying also re-

146 Ibid., p.4, col. 3 .

147 Ibid.

148 Journals of the House of Commons of the Dominion of Canada, From the $4^{\text {th }}$ February to the $8^{\text {th }}$ April, 1875, (Hunter Rose: Ottawa, 1875), A2-1, A2-14.

149 Shelia McManus, The Line Which Separates: Race, Gender, and the Making of the Alberta-Montana Borderlands, (Edmonton: University of Alberta Press, 2005), xviii. This post-colonial perspective of Canadian history is also presented in Julie Cruikshank, Do Glaciers Listen?: Local Knowledge, Colonial Encounters, and Social Imagination, (Vancouver: UBC Press, 2005); Adele Perry, On the Edge of Empire: Gender, Race, and the Making of British Columbia, 1849-1871, (Toronto: University of Toronto Press, 2001). 
configured the spatial dimensions of the Canadian west within a liberal philosophy that promoted individualist property ownership, which Ian McKay has called a fundamental aspect of the classical liberal order from the 1840 s to the $1940 \mathrm{~s} .{ }^{150}$

O'Hanly worked on the Ontario-Quebec boundary survey of 1873-74, where he was employed as boundary commissioner for the Province of Ontario. O'Hanly received his instructions for the Ontario-Quebec boundary survey in March 1872. He was to proceed to the mouth of the Mattawan River and determine the latitude. He was then to proceed to the west side of the Ottawa River where he was to survey the islands in the lake and river and determine their positions. O'Hanly was instructed to plant structures along the line that were to be marked out by the surveying team, to sketch the natural features of the ground over which the line passed, and note the character of the soil and the timber. In all, O'Hanly spent 253 days on this project from 21 October 211872 through 30 June $1873 .^{151}$

O'Hanly was also employed on the Manitoba boundary survey of 1881 . Just over a decade previous in 1869/70 Louis Riel led a Métis resistance against the encroachment of the Dominion government. The imposition of the liberal order in western Canada was not a benign process. Robin Jarvis Brownlie has argued that the advance of liberal ideas such as private property and acquisitive individualism did not offer aboriginals much of value, given that they stood to lose their land, social cohesion, and cultural identity in the process. In fact, Brownlie asserts, "radical appropriation of land accomplished through the extension of the private property regime across aboriginal territories was a devastating material loss for First Nations." ${ }^{152}$ Tensions had not dissipated following Manitoba's entry into Confederation in

${ }^{150}$ Ian McKay, "Canada as a Long Liberal Revolution: On Writing the History of Actually Existing Canadian Liberalisms, 1840s-1940s," in Liberalism and Hegemony: Debating the Canadian Liberal Revolution, edited by Jean-François Constant and Michel Ducharme, (Toronto: University of Toronto Press, 2009), 376.

${ }^{151}$ LAC, O'Hanly Papers, MG 29, B11, Volume 10, File 24, "Ontario-Quebec Boundary Survey."

152 Robin Jarvis Brownlie, "A Persistent Antagonism: First Nations and the Liberal Order," in Liberalism and Hegemony: Debating the Canadian Liberal Revolution, Jean-Francois Constant and Michel Ducharme, 
1870 , and within this context the Canadian state sought to use map-making as a strategy to control the land and the population. O'Hanly was head surveyor on this endeavour, reporting to Lindsay Russell, Surveyor General of Dominion Lands who worked in the Department of Interior. O'Hanly's work on this project was much the same as his work on the OntarioQuebec survey, marking lines for boundaries, and keeping notes on the region's natural resources such as types of soil and trees. ${ }^{153}$ It also brought him to consider the capacity for citizenship of the indigenous population.

This particular time in Manitoba was also significant in the Canadian nation-building project as it was only shortly after the passage of The Indian Act of 1876, which was a consolidation of previous laws concerning the governing of aboriginals. ${ }^{154}$ The Indian Act promoted assimilation policy; it made aboriginals wards of the state and banned traditional cultural practices such as the potlatch. There was perhaps no clearer act of colonialism in the imperial project than the establishment of a system of reserves for aboriginals. The reserve system set aboriginals apart from broader society until they could be "civilized" by state authorities. The imperial tool of mapping, which created physical boundaries between "Indians" and "whites," worked simultaneously with creating cultural boundaries and racial categories between them. It was possible to physically separate aboriginals from the rest of the population because this way of thinking had been established for years. In turn, physically separating aboriginals on reserves from the rest of the population extended the notion that they were "different," and hence inferior. This mutually constitutive process of transforming the material and cultural landscape was fundamental to the imperial project, as was the civilizing discourse that accompanied it.

(Toronto: University of Toronto Press, 2009), 315.

153 LAC, O'Hanly Papers, MG 29 B11, Volume 10, File 25, "Manitoba Boundary Survey."

154 For a useful general overview of the Indian Act and its assimilationist objectives see John F. Leslie, "The Indian Act: An Historical Perspective," Canadian Parliamentary Review 25.2 (2002). 
Involvement in the material and cultural re-constructions of space based on Western forms of knowledge did not mean that O'Hanly uncritically supported Canadian colonialism. He opposed government policies toward aboriginals because he felt they created a sense of dependency within the aboriginal population, rather than cultivating a sense of individualism. Yet, O'Hanly did not see this as a reason to abandon colonial practices. It was his view that efforts geared toward "civilizing" the native population were necessary, but should create responsible individuals able to look after themselves. He believed that aboriginals had the capability to be good citizens and autonomous individuals, but only after they had been "civilized" through liberal colonial practices. His views on this subject were most forcefully expressed in a paper entitled "The Indian." 155 In it, O'Hanly issued a scathing critique of the actions of the Canadian government toward aboriginals in Canada. O'Hanly argued against the idea "drummed into the public ear, yet utterly devoid of truth...that Indians are lazy and will not work." It was not the aboriginal population that was to blame for their state, believed O'Hanly, but rather poorly thought-out governmental policies regarding their treatment of aboriginals. The government, argued O'Hanly, had failed to live up to the responsibilities it had set for itself: "we folded our arms in indifference, forgetting or ignoring the trust voluntarily assumed when we seized his possessions and by a legal fiction deprived him of all rights, reducing him to the condition of a minor or a maniac." O'Hanly demonstrated a paternalistic attitude toward the aboriginal population, lamenting that "a helping hand we never stretched forth to ameliorate his condition, to redeem or rescue him from barbarism." 156

In "The Indian,” O'Hanly defined aboriginals as savages, wearing costumes, clinging to a non-English language. It was their difference from Western culture that O'Hanly held to 155 O'Hanly Papers, LAC, MG 29, B11, Volume 20 File 4 "Indian Affairs," Undated.

156 Ibid. 
be essential to their identity. Once these identities based on difference were outlined, he then sought to explore the similarities between their culture and Western culture by comparing what he called "the progress of the several tribes." 157 This comparative approach ranked the aboriginal groups of Canada based on O'Hanly's criteria, which placed great emphasis on Western forms of knowledge such as science and economic progress. O'Hanly believed that even the least cultivated of the Winnipeg tribes were far ahead of the most advanced Eastern Canadian tribes in his hierarchy of civilization. O'Hanly asserted that this resulted from contact that Canadian tribes had with what he sarcastically called "our humane and beneficent treatment of the poor Red Man." ${ }^{\prime 158}$ O'Hanly was critical of the treatment of aboriginals and offered the following comment regarding the Winnipeg tribes: "since their contact with civilization — fatal to them as to all their race through no fault of their owndeteriorating influences are at work, which if not stopped will soon reduce them to the same low level as their brethren in Canada." 159 O'Hanly invoked the "extinction" narrative, arguing that as a result of contact with the Canadian state aboriginals were being transformed into an abject population. The prospect of extinction troubled O'Hanly because he believed that by their inherent nature, aboriginals were "fitted for as high a degree of culture and civilization as any race hitherto rescued from barbarism, and if he is not today enjoying all the benefits of civilized life it is owing to the culpable neglect in the past of his would be guardians." 160

O'Hanly thus argued that the aboriginal population had inherent characteristics that made them suited to enjoy the benefits of civilization and culture, but that these inherent characteristics had to be cultivated under the influence of external forces. According to 157 Ibid.

158 Ibid.

159 Ibid.

160 Ibid. 
O'Hanly the aim of all relief should be the transformation "from the savage to the civilized state...to extinguish the savage Indian and raise in his stead a civilized Indian." ${ }^{161}$

“Civilization," observed O'Hanly, could only be achieved by aboriginals if administered by the forces of colonialism. O'Hanly was constructing an "Indian" identity for Western consumption, in order to justify imposing the more "civilized" Western culture to supplant pre-existing aboriginal ways of life. It was not that O'Hanly opposed state intervention into the lives of aboriginals. Rather, he objected to how the state intervened. O'Hanly believed in the necessity of the civilizing mission to transform aboriginals into autonomous individuals, but objected to the ways the government was going about that mission.

O'Hanly was a promoter of railway expansion, which, along with the scientific and technological advancements that allowed for this expansion, was a fundamental marker of progress and improvement in the nineteenth century. In Machines As the Measure of Men Michael Adas argues they were also key symbols of colonialism. Not only did these forms of knowledge aid colonists in transforming the physical landscape through their application of Western forms of property, but their belief in the superiority of Western based knowledge "buttressed critiques of non-Western value systems and modes of organization." 162 O'Hanly participated in the expansion of scientific forms of knowledge in his work on major railway projects during the second half of the nineteenth century. He was employed as an engineer on the Intercolonial Railway in 1869, a division engineer on the Canadian Pacific Railway in 1871 and 1875 , and he was chief engineer and director of two smaller railway lines that he and his business partners organized, the Ottawa and Gatineau Railway and the Ontario Pacific Railway. O'Hanly was an active promoter of the progress he felt was engendered

161 Ibid.

162 Michael Adas, Machines As the Measure of Men: Science, Technology, and Ideologies of Western Dominance, (New York: Cornell University Press, 1989), 15. 
through the technological advancements associated with railways. As he wrote,

The nineteenth century has witnessed a marvellous development in the subjection of natural forces...to control of man...it (the nineteenth century) has beheld the infancy, growth, and maturity of railroads with all the ingenious mechanical devices which have kept up with its progress... a journey from Ottawa to Montreal through the primitive forest would take three or four weeks of arduous toll, peril, and privations at a very great expense...this can not be done in as many hours at a trifling cost with all the comfort and luxury of a palace on wheels. ${ }^{163}$

The Ottawa and Gatineau Railway was to connect the hinterlands to the emerging urban centre of Ottawa. To promote the building of this railway in the 1870s, O'Hanly employed arguments infused with the social philosophy of liberalism, focusing on both the economic and moral improvements that would accompany its construction. He argued that railroads were the veins and arteries of the body politic, because through them flowed the agricultural productions and commercial supplies which were the life-blood of the state. Without these transportation routes, argued O'Hanly, the richest productions of nature rot and waste. He observed that before railroads were laid across the prairies the west was no better than a "barren wasteland." ${ }^{164}$ A well-planned rail-line throughout the land around the city of Ottawa could, according to O'Hanly, bring economic benefits to the area. Because the land adjacent to the mineral- and resource-rich Ottawa country was "thoroughly neglected" the citizens there were ostracized and "shut out from the rest of creation." 165 A railway connecting these two areas "would add largely to the wealth and population of Lower Canada." 166 In addition to the economic benefits of such a project, O'Hanly argued that the moral environment would be improved as a result of the construction of railroads. He pointed to the example of the Highlands in Scotland, and how the habits of the working

${ }^{163}$ LAC, O'Hanly Papers, MG 29, B11, Volume 10, File 5, "Ontario and Pacific Survey."

164 LAC, O'Hanly Papers, MG 29, B11, Volume 7, File 9, "Ottawa and Gatineau Railway," Undated.

${ }^{165}$ Ibid.

166 Ibid. 
classes there had been improved from the increased and improved facilities of communication, and noted that a similar transformation would occur in the Ottawa Valley in the wake of the railway. ${ }^{167}$

Tied to his enthusiasm for railway expansion was O'Hanly's support for colonization of the prairies in order to open up lands to prospective immigrants. ${ }^{168}$ Beginning in earnest with the passage of the Dominion Lands Act in 1872 following the government's acquisition of Rupert's Land in 1870, colonization schemes aimed to attract immigrants to the Canadian west with the promise of land and opportunity. O'Hanly hoped for these intending settlers to establish an agricultural economy that, in conjunction with railway development, would bring goods to larger markets across the new Canadian territory. For O'Hanly there were qualifications that prospective agricultural settlers had to meet. He divided prospective settlers into two classes. First were immigrants from Europe, whom O'Hanly reasoned should receive a free grant of 200 acres to begin their homesteading. The other class of settlers O'Hanly wanted to see re-settle the land were "the more indigent class...those who live in our towns and cities on a daily wage — the precarious wage of a day." ${ }^{\prime 169}$ These prospective settlers should be furnished with farm implements, cattle and seed, and receive a sufficient sum for transport and maintenance until the first crop was garnered. He argued that these monetary advances, "with moderate interest" should be payable in ten years. The hardworking immigrant and the hard-working day labourer transformed into pioneer with improved moral qualities were necessary for his colonization plans. In keeping with his support for self-improvement, O'Hanly opposed land speculators because he believed they

${ }^{167}$ Ibid. It is ironic that O'Hanly used the example of the Scottish Highlands to make his argument, as that process aimed to transform the social structure of the Highlanders in order to integrate them into the British state.

${ }^{168}$ LAC, O'Hanly Papers, MG 29, B11, Volume 20, File 9 "Land Policy, The Northwest Land Regulations," Undated.

169 Ibid. 
would monopolize the region. His plans would not allow any man whose real and personal property exceeded $\$ 1000$ a single acre of land, and would make every man who claimed a homestead make a declaration to that effect. ${ }^{170} \mathrm{O}$ 'Hanly felt the individuals and families resettling the land ought to be of the proper moral quality. He noted that in his professional capacity he had come into contact with these "pioneers of civilization" and he admired their "upward and onward struggles," as well as their "steady and undaunted perseverance under trying hardships." ${ }^{171} \mathrm{O}^{\prime}$ Hanly thus employed the rhetoric of rugged individualism and the pioneer myth to support colonization schemes that would be a part of the self-improvement of the settlers through their ownership of property.

Though O'Hanly held condescending views on the "primitive" state of aboriginals, in his professional capacity he was somewhat sympathetic to their plight as they became entangled in the global forces of colonialism. Yet O'Hanly's view that Irish Catholics were the victims of British discrimination and abuses of power in both Ireland and Canada did not lead him to adopt a perspective of shared brotherhood between the Irish and aboriginals as two groups impacted by the violence and oppression of colonialism. In fact, it is possible that O'Hanly believed that such an association between Irish Catholics and aboriginals would have weakened the cause of the former by aligning them with aboriginals, whom O'Hanly viewed as "barbarians." Though he saw them as civilizable, and having the inherent capacity to become good citizens and autonomous individuals with "proper instruction," in his other writings he argued the heightened civilization of the Irish and thus their worthiness for equality in the Canadian state and fitness for running their own country free from British authority.

Ireland's colonial status is at the heart of the matter when probing possible links

170 Ibid.

171 Ibid. 
between O'Hanly's views on Irish Catholics and aboriginals. Scholars remain divided on the classification of Ireland's colonial status. Terry Eagleton has argued that the relationship between Britain and Ireland was most certainly a colonial one, which makes it appropriate to consider Ireland's experiences within the same paradigm as non-European colonies. ${ }^{172}$ Declan Kiberd has likewise argued that Ireland's political, economic, cultural, and ideological domination by Britain was a form of colonialism that only ebbed through a protracted process of decolonization following 1921. ${ }^{173}$ Stephen Howe presented a more ambivalent view of Ireland's colonial status, arguing that Ireland was seen as both a sovereign kingdom and a location fit for colonial exploitation prior to the Act of Union, and that ambivalence was never fully erased. ${ }^{174}$ Liam Kennedy, on the other hand, has demonstrated there existed higher living standards in Ireland relative to non-European colonies, and thus concluded that a meaningful comparison between the two cannot occur and Ireland cannot rightly be considered a colony. ${ }^{175}$

This field of inquiry also addresses questions regarding the extent to which the Irish nationalist movement can be categorized as an anti-colonial movement, as well as whether the Irish nationalist movement categorized itself as such. In studies that approach this issue, the place of Ireland and the Irish in the British Empire ranges from the work of Cook and Kehoe, who explored the complicity of the Irish in imperial expansion, to the subversive role the Irish played alongside other anti-colonial activists. Matthew Kelly and Paul Townend have presented two important examples of the imperial subversion of the Irish. While Kelly

172 Terry Eagleton, “Afterword: Ireland and Colonialism”, in Was Ireland a Colony? Economics, Politics and Culture in Nineteenth-Century Ireland, ed. Terrence McDonough (Dublin: Irish Academic Press, 2005), 326.

173 Declan Kiberd, Inventing Ireland: The Literature of the Modern Nation, (Cambridge: Harvard University Press, 1997), 6.

174 Stephen Howe, Ireland and Empire: Colonial Legacies in Irish Histories and Culture (Oxford: Oxford University Press, 2000), 13.

175 Liam Kennedy, Colonialism, Religion and Nationalism in Ireland (Belfast: Institute of Irish Studies, 1996), Chapter 7. 
has argued that until recently, Irish nationalists never accepted that they were colonized, thus making their identification with other anti-colonial movements seemingly impossible, in his study of Irish nationalism in the 1850s and 1860s he found that a heightened level of anticolonialism and solidarity with non-European colonies existed in the Irish press. He thus concluded that anti-imperialism was a powerful component of Irish nationalist thought and rhetoric at that juncture. ${ }^{176}$ Townend probed how imperialism shaped Irish nationalism, and the degree to which anti-colonialism was integral to Irish nationalism as a social movement. Exploring the Irish Home Rule campaign of the 1870s and 1880s, Townend found that antiBritish and anti-colonial solidarity existed between Irish nationalists in Ireland and Zulu nationalists in Africa. Townend observed that throughout the politically charged year of 1879 , the Irish press condemned British imperial policies in South Africa and championed the cause of the Zulus. ${ }^{177}$

A brief review of this literature demonstrates that the relationship between Irish nationalism and anti-colonialism was marked by ambivalence. Illustrations provided by Kelly and Townend demonstrate Irish nationalist identification with other anti-colonial movements, yet contrasting examples, such as O'Hanly's racialized views on Canadian aboriginals, abound. Pauline Collombier-Lakeman remarks that major figures in the Irish nationalist movement including Daniel O'Connell, Issac Butt, Charles Stewart Parnell, and John Redmond all used the themes of slavery to present the Irish as victims of British domination and oppression. ${ }^{178}$ Yet, she goes on to argue, those leaders were careful not to present Ireland as a British colony. Instead, they described the Irish political situation as

\footnotetext{
${ }_{176}$ Matthew Kelly, "Irish Nationalist Opinion and the British Empire in the 1850s and 1860s", Past and Present 204 (August 2009): 130.

177 Paul A Townend, "Between Two Worlds: Irish Nationalists and Imperial Crisis, 1878-1880," Past and Present 194 (February 2007): 148.

178 Collombier-Lakeman, "Ireland and the Empire," 60.
} 
provincial rather than colonial. ${ }^{179}$ Collombier-Lakeman suggests that one of the reasons why Irish nationalist leaders did not frame Ireland as a colony is because Ireland and Irish people have historically been deeply involved in the construction and expansion of the British Empire. ${ }^{180}$

By and large, anti-colonial writers have not included Ireland in their analyses, and Irish nationalists have not framed Ireland's colonial status as analogous to non-European colonies. This separation from non-European colonialisms suggests a relationship between the ways in which Irish nationalists such as O'Hanly framed Irish identity in contradistinction to non-European identity. Indeed, O'Hanly's condescending views on aboriginals and his self-righteous Irish nationalism serve to demonstrate how he perceived the place of Irish Catholics in Canada, the British Empire, and historical context. From O'Hanly's perspective, aboriginals were uncivilized and primitive, hence unworthy for citizenship without proper guidance from white men. On the other hand, Irish Catholics, especially professional men like himself who espoused a liberal ideology, were automatically placed at the top of the civilization hierarchy and thus worthy of equality in Canada and fit to govern themselves in an independent Ireland. In O'Hanly's estimation, the fact that Irish Catholics were treated unjustly in Canada, and forced to live under British rule in Ireland, was all the more shameful because the Irish, unlike aboriginals, were a "civilized" race. O'Hanly, like Boyle and even O'Leary, was driven by a belief in the middle-class liberal values of individualism, independence, and self-improvement, and embraced settler colonialism to advance that liberal order.

${ }^{179}$ For this point also see Sean Ryder, "Defining Colony and Empire in Early Nineteenth Century Nationalism," in Was Ireland a Colony? Economics, Politics and Culture in Nineteenth-Century Ireland, edited by Terrence McDonough, (Dublin: Irish Academic Press, 2005), 180.

${ }^{180}$ Collombier-Lakeman, "Ireland and the Empire," 61; Before 1801 Ireland was one of the three kingdoms but the Act of Union, in abolishing the Irish Parliament and having Irish constituencies elect members to Westminster, had reduced its constitutional status to a provincial one. 


\section{$\underline{\text { Conclusions }}$}

For some time there had been a growing sense among prominent Irish Catholic individuals and some Irish Catholic organizations that they were being treated unfairly by Protestant Canada. The response to the Fenian attacks by authorities - the suspension of habeas corpus and what was seen by some as specious suspicions cast upon the entire Irish Catholic population - further justified this belief. The reaction of middle-class non-Fenian Irish Catholics to the Fenian Raids of 1866 is reflective of the complexity and diversity within the community. Most valued their place in Canada and accepted McGee's call to demonstrate loyalty and reject Fenians who purported to fight in their name. Clerics opposed the Fenians because they saw it as a secret oath-bound organization that was not under Church authority, while the laity opposed the Fenians on liberal grounds, seeing them as offensive to the Canadian liberal order of which they sought to become a part. They used the occasion to demonstrate their acceptable liberalism to Canadian society by rejecting the revolutionary activities of the Fenians. Even the clergy's preferred papers espoused some of the language of liberal "rights talk."

Patrick Boyle and J.L.P. O'Hanly instead took a combative approach and refused to back down from their more radical beliefs in the wake of the raids. They were angered by the accomodationists' demand that they show loyalty. They demanded the rights of the British constitution and due process, arguing that the onus ought to be on the authorities to provide evidence about which specific Irish Catholics were part of the Fenian threat, rather than on the entire Irish Catholic population to show they were not part of that threat. In pointing out inconsistencies in a liberal state that did not protect their individual liberties, they were exposing the lies and hypocrisies underlying the liberal order using liberal 
arguments about justice, fairness, and equality.

The Fenian organization was not the kind of voluntary association explored by Greer and Radforth, McNairn, or Ferry. Those authors explored mainstream Protestant associations in nineteenth-century Canada and found that they were fundamental in the formation of the Canadian state, democracy, and liberal culture. In contrast, the Fenians challenged British Protestant Canada and its ascendent liberal order. Yet, the examples of Boyle and O'Hanly demonstrate that individual supporters or sympathizers of the Fenian organization could be fundamental in the formation of modern Canada and the liberal order, too. They advocated for a more thoroughly liberal order by denouncing public suspicions and official abuses of the instruments of state coercion. Their radical nationalist views were consistent with the liberal individualism that was also at the heart of their support of settler colonialism.

Though on the face of things that support seemed to advance the power of the British Empire, O’Hanly distinguished Irish victimization from that of less civilized subject peoples and constructed western expansion as a domestic liberal project, much like Boyle's temperance efforts amongst immigrants. Thus it was not simply the economic but also the moral benefits of settler colonialism that appealed to Boyle and O'Hanly, affirming their positions as liberal, middle-class Victorians, but also as Irish Catholics. Neither the moderates nor the radicals abandoned their belief in Irish nationalism because of the negative reaction of the public to the Fenians. They were quick to denounce English imperialism by contrasting its negative consequences in Ireland with the positive aspects of life in Canada. Their rebuke of English imperialism created a distinction between respectable nationalism and the physical force Fenian version. Support for Irish independence would be a key component of Canadian Irish-Catholic identity. In the 1880s O'Hanly would rally Irish Catholic voluntary associations behind Canadian Parliamentary resolutions urging Britain to 
see Irish Home Rule as akin to colonial responsible government. But in the 1870s Boyle and O'Hanly first turned their attention to improving the political standing of Irish Catholics in Canada. To that topic this dissertation now turns. 
Chapter Seven: The Catholic League and The Liberal State

\section{$\underline{\text { Politics and Patronage }}$}

This chapter explores how the perceived loss of Irish Catholic political capital following the Fenian Raids and their exclusion from elected and appointed office under the liberal state in the immediate post-Confederation period became a source of grievance. As a consequence the Ontario-based Catholic League was formed in 1871 and this chapter will focus on their activities in the federal elections of 1872 and $1874^{1}$.

During the union period patronage was a key issue for the Irish community. In the system of responsible government, the cabinet held office only so long as they could control a majority in the house. This meant that parties needed to capture a wider range of interests to stay in office. The necessity of assembling coalitions that would attract both Catholic and Protestant voters meant that Catholics found some advantage in appointments being doled out on the basis of ethnicity and religion to secure their support. Thus, while the issue of

One of the reasons why the League focused its actions solely in Ontario was related to patronage. Since Confederation the federal government lost much of the patronage that formerly belonged to the old government of Canada. The local and country patronage positions belonged to the provincial governments, while federal appointments included judges, custom, excise, and post offices. James George Moylan Fonds, MG 29-D15, LAC, Macdonald to Bishop John Walsh, 9 December 1871. The Catholic League addressed Irish Catholic interests in Ontario at all three levels of government. For instance, at the provincial level the 1879 appointment of Thomas McCrosson to the position of superintendent of the Reformatory Prison at Penetanguishene was attributed to the desire of the Liberal government of Oliver Mowat to place Catholics in important government jobs. McCrosson was an associate of Smith and in his position as editor of the Irish Catholic Toronto Tribune advanced the position of the Catholic League. Peter Oliver, "McCROSSON, THOMAS," in Dictionary of Canadian Biography, vol. 13, University of Toronto/Université Laval, 2003-, accessed March 1, 2016, http://www.biographi.ca/en/bio/mccrosson_thomas_13E.html. The Ontario Liberal Premier Mowat was thus alive to the need to balance Catholic and Protestants in his government. In his 1872 pamphlet written under the auspices of the Catholic League, J.L.P. O'Hanly discussed the government's redrawing of the municipal ward boundaries in creation of the City of Ottawa in 1855 to guarantee a Protestant majority, and then how they proceeded to dismiss every Catholic from the city administration. John Lawrence Power O'Hanly, The Political Standing of Irish Catholics in Canada, A Critical Analysis of its Causes, With Suggestions for its Amelioration, CIHM 23746, 47. There was thus also a sense of Irish alienation from the state apparatus at the municipal level. Nevertheless, this chapter primarily deals with the activities of the Catholic League in federal elections in the 1870s. I made this decision because the League was most active in the federal elections of 1872 and 1874. 
patronage was intractably linked to office-holding, patronage also became a key way of satisfying various ethno-religious constituencies. ${ }^{2}$

In 1840s Canada West, letters of application and letters of recommendation for the appointment of magistrates make the case that an applicant's religious affiliation was sometimes an important consideration in judicial appointments. ${ }^{3}$ Banoub likewise notes that patronage requests in New Brunswick in the 1860s often made reference to the need for appointments to balance positions between Catholics and Protestants. ${ }^{4}$ George Emery has argued that access to patronage required holding office, thus patronage and partisanship went hand in hand. ${ }^{5}$ Operating with this principle in mind, the Catholic League argued that Orange-influenced Conservatives had treated Catholics unfairly with respect to patronage appointments both before and following Confederation and it was in the collective selfinterest of the Irish Catholic community to vote as a block for the Liberal Party.

Catholics like J.L.P. O'Hanly believed that Irish Catholic influence was waning as the power of Orangeism increased. The Catholics' loss of political capital in the wake of the Fenian Raids was followed by a growing fear that Confederation would simply add another political level in which they suffered underrepresentation. The perception of discrimination increased following Confederation and the formation of the Catholic League was meant to remedy this state of affairs.

The executive of the Catholic League was made up of Irish Catholics who were either running for political office or were otherwise involved in the political process and

2 S.J.R. Noel, Patrons, Clients, Brokers: Ontario Society and Politics, 1791-1896 (Toronto: University of Toronto Press, 1990), 14; David Banoub, "The Patronage Effect: Civil Service Reforms, Job-Seeking, and State Formation in Victorian Canada," (PhD diss., Carleton University, 2013), 158.

3 Archives of Ontario, Correspondence of the Provincial Secretary's Office for Canada West, RG 8-23, Rev. Terence Smith of Richmond writing about the unequal representation of Catholics, 29 March 1843; John McCormack - request for Catholic magistrates in Midland District, 27 June 1845.

4 Banoub, "The Patronage Effect," 178.

5 George Emery, Principles and Gerrymanders: Parliamentary Redistribution of Ridings in Ontario, 18401954, (Montreal \& Kingston: McGill-Queen's University Press, 2015), 9. 
membership was limited to Ontario. Members urged their co-religionists and fellowcountrymen to vote only for Irish Catholic candidates aligned with the Catholic League in order to secure fair and equal standing for their ethno-religious community, and thus challenged existing power relations. They believed that the respectability achieved through temperance associations demonstrated the self-regulation seen as a prerequisite for governing others. But they felt they had lost political capital in the wake of the Fenian Raids, despite the efforts of the moderates amongst them to demonstrate loyalty to Canada and the Empire. There was a sense that they were receiving unfair treatment and the Catholic League aimed to use political office, patronage, and the career advancement that entailed to positively modify the position of Irish Catholics and include them in the power structure of the Canadian liberal state.

Among Irish Catholics there was a sense that they were being denied government appointments. There was some basis in fact for these opinions. Given that voting rights before and after Confederation were restricted by property and income-based qualifications, there were structural impediments to full participation in the public sphere for non-elite Irish Catholics. Even for Irish Catholics of higher social standing, barriers to political office and appointments were tangible. William Jenkins notes that in Toronto, for instance, if a political machine existed it was one that fused Orange and Conservative interests. Jenkins concludes that for Catholics of Irish birth or ancestry, it was all but impossible to ignore the economic, political and institutional power held by Protestants of various denominations. ${ }^{6}$ In a recent study, William Smyth likewise argues that the Orange Order was the main vehicle for the acquisition and distribution of patronage in the city, and is the closest Canadian equivalent of

6 William Jenkins, Between Raid and Rebellion: The Irish in Buffalo and Toronto, 1867-1914, (Montreal and Kingston: McGill-Queen's University Press, 2013), 164. 
the machine politics of American cities. ${ }^{7}$ The Catholic League aimed to challenge the power of the Orange machine. ${ }^{8}$ Members believed that systemic discrimination and the effective exclusion of Irish Catholics from participation in the polity under responsible government and in the new Dominion was a concrete reality and reforming this situation involved both getting Catholics elected to public office and ensuring them at least a fair share of civil service and other public appointments.

One of the main areas that the League critiqued was patronage and the failure to appoint Irish Catholics to government positions. Political patronage is the dispensation of favours or rewards such as public office, jobs, and contracts by a patron (the government) to a client. ${ }^{9}$ Within this paradigm, the governing party can fill the state apparatus with individuals who owe their careers and livelihoods to them, and thus all but guarantee the loyalty and obedience of the clients. As Gordon Stewart remarked, patronage was endemic to Canadian politics in the $1867-1911$ period. ${ }^{10}$ W.L. Morton argued that the power to distribute patronage gave the cabinet minister's office meaning and substance. ${ }^{11}$ While William Smyth notes that the patronage process was a legally acceptable means of rewarding able persons, individual appointments often created controversy. ${ }^{12}$ Though patronage was a seemingly indispensable part of Canadian politics since the time of John Graves Simcoe, it was not necessarily a positive or benign aspect. Numerous commissions were established to investigate the civil service and to look at the inner-workings of patronage. ${ }^{13}$ Critics charged

7 William J. Smyth, Toronto, The Belfast of Canada: The Orange Order and the Shaping of Municipal Culture, (Toronto: University of Toronto Press, 2015), 119.

8 Michael Cottrell, "John O'Donohoe and the Politics of Ethnicity in Nineteenth-Century Ontario," CCHA, Historical Studies 56 (1989): 75.

9 Frederick Lee Morton, "Judicial Recruitment and Selection," in Law, Politics, and the Judicial Process in Canada, edited by Frederick Lee Morton (Calgary: University of Calgary Press, 2002), 121.

10 Gordon Stewart, "Political Patronage Under Macdonald and Laurier, 1878-1911," American Review of Canadian Studies Volume 10, Issue 1 (1980): 3.

11 Cited in Stewart, "Political Patronage," 3.

12 Smyth, Toronto, the Belfast of Canada, 117.

13 Early reforms to the civil service included the 1857 Act for Improving the Organization and Increasing the 
that patronage undermined merit and equal access to the state by allowing the government to pick and choose loyal clients. Public opinion was swinging strongly in the direction of meritocracy and the failure of legislation to check the practice was becoming increasingly a source of frustration. This was a transitional period in which applications for public office were as likely to emphasize the party affiliation and personal connection of the old patron/client relationships as the education and skills demanded by a more impersonal, rational and efficient bureaucracy. David Banoub argues that reforms to the civil service and debates regarding patronage in the nineteenth century were about more than the administrative appointment process: they were about "imagining the public, political service and reward, and what type of person should be a civil servant." 14

Debates surrounding the nature of patronage within the nineteenth-century liberal state call to mind the work of Suzanne Zeller and A.A. den Otter, who argued that Canadian liberals attempted to tie the ideas of "progress, expansion, technology, and reason" to ideas of Canadian nationalism in the optimistic hope that scientific thought would lay to rest "irrational" ideas and religious tensions. ${ }^{15}$ Yet despite calls to reform the patronage system within the liberal state, traditional views on the structure of patronage appointments continued to carry weight. Banoub, for instance, has argued that emotion and irrationality, which included ethnic divisions and interests as well as religious tensions, sabotaged this idea of a rational meritocracy. ${ }^{16}$

It would be easy to group the League with those who sought civil service reforms

Efficiency of the Civil Service in Canada, the 1868 Canada Civil Service Act, and the 1882 Civil Service Act. For the historiography of these reforms, see Banoub, "Patronage Effect," 12-15.

14 Banoub, "The Patronage Effect," 3.

15 Suzanne Zeller, Inventing Canada: Early Victorian Science and the Idea of a Transcontinental Nation, (Toronto: University of Toronto Press, 1987), 8; A.A. den Otter, The Philosophy of Railways: The Transcontinental Railway Idea in British North America, (Toronto: University of Toronto Press), 30. 16 Banoub, "The Patronage Effect," 255-6. 
through the disestablishment of irrational and "old style" patronage and bureaucracy. Yet calls by the Catholic League for reform of the civil service and patronage system were not directed toward implementing a meritocracy. They pointed out the exclusion of Irish Catholics from the patronage system and called for an increase in the representation of their co-religionists and fellow-countrymen. Banoub points out that the old "irrational" values and the new "rational administration" perspective intermingled in this period, and slowed the process of liberalization. ${ }^{17}$ And we can see that with Irish Catholics as well. They emphasized their qualifications for office but concluded that until politics was eliminated from the appointments process they needed to exert political pressure to ensure equal representation.

In an environment of evolving liberal governmentality and the public sphere, the Catholic League and O'Hanly adopt the liberal language of bureaucratic meritocracy and rational government in justifying Irish Catholic eligibility for office. O'Hanly argued that their adoption of a seemingly retrograde ethno-religious voting block was a desperate response to the lack of equation between ideal and reality in the liberal state and the exclusionary influence exerted against them by the Orangemen within the governing party. The level of public discourse and climate of public opinion had changed sufficiently by the 1870 s that the argument for Catholic representation had to be made in these terms. O’Hanly's degree of facility in advancing a nuanced argument in terms of rights and rationality, like his analysis of settler colonialism outlined in the previous chapter, suggest that he was a genuine middle-class Victorian liberal, not free from the Victorians' racial assumptions, but keen to see participation in the liberal state the right of all civilized peoples.

17 Ibid. 
The Catholic League, the Liberal Party, and the Push for Unity

The fluctuating political situation which reduced their influence produced a desire among some Irish Catholics for the formation of political organizations that would present a united front and coherent voting block, while acting in the interests of their ethno-religious community. In this spirit, an Irish Catholic political meeting was called in 1867 at St. Lawrence Hall in Toronto. ${ }^{18}$ Yet, the rancour which accompanied this convention demonstrates the difficulty of overcoming partisan divisions. This convention was held because of Confederation. There would now be two levels of government in which Catholics would need to seek representation. The meeting was led by Frank Smith and John O'Donohoe, both of whom were Liberals, and was called to address the decision by Thomas D'Arcy McGee to run at the federal level as a supporter of Macdonald that, in the wake of the latter's handling of habeas corpus and the Cornwall arrests, upset Smith, O'Donohoe, and other leading Irish Catholics. After much discussion and debate, resolutions were carried stating that McGee did not represent the Catholics of Ontario and that they were not prepared to follow him. The debate and discussion that preceded the passing of those resolutions were due to the presence of a sizable number of Catholic Conservative supporters who were in favour of McGee's "new attitude." Conservative supporter James George Moylan, editor of the Irish Catholic Canadian Freeman, opposed the reform orientation of the convention and labelled this the "Brown Convention" to denigrate what he viewed as the move into the arms of reform leader George Brown. ${ }^{19}$ In the wake of the Convention, Moylan told Conservative leader Macdonald that he could "checkmate and

18 Globe (Toronto), 12 July 1867, p. 1, col. 9.

19 Shanahan, David. "The Irish Question in Canada: Ireland, the Irish and Canadian Politics: 1880-1922." (PhD diss. Carleton University, 1989), 27; Irish Canadian (Toronto), 12 October 1872, p. 4, col. 6. 
counteract" the Catholic Convention. In return, Macdonald assured Moylan that "the government would sustain" him thoroughly and he expected Moylan to put his "shoulder strongly to the wheel." ${ }^{20}$ True to his word, Moylan did attack the Catholic League throughout the 1870 s in his editorials. ${ }^{21}$

The 1867 Catholic Convention was a meeting that saw the Liberals censure McGee and try to speak for the assemblage in denying him their support, but only after considerable rebuttal from Conservatives. While Michael Cottrell has argued that this convention of Irish Catholics had little immediate impact, he did note that it demonstrated the "persistence of Irish alienation and brought together middle-class Irish Catholics such as O'Donohoe and Frank Smith, and Irish nationalist leaders such as Patrick Boyle." ${ }^{22}$ This 1867 convention, and the hostilities which it produced, shows that tensions between Liberal and Conservative Irish Catholics remained a considerable barrier to united political action in the Irish Catholic interest.

A major foray attempting to unite the Irish Catholic community into a voting block occurred in 1871 with the formation of the Catholic League, also spearheaded by O'Donohoe and Smith. John O'Donohoe had emigrated to Canada with his family from Galway prior to the Famine. A Liberal, he was elected Alderman for Toronto's St David's Ward in 1850, and was called to the bar in 1869 . He had been active in Toronto's Irish Catholic community for some years as secretary of the St Patrick's Benevolent Society and later president of that organization. ${ }^{23}$ According to his entry in the Canadian Biographical Dictionary, O'Donohoe

20 LAC, James George Moylan Fonds, MG 29 D15, Macdonald to Moylan, 4 July 1867.

21 See, for instance, Canadian Freeman (Toronto), 6 June 1872, p. 2, col. 5 in which Moylan censures what he referred to as the "so-called" Catholic League and asserted that the Hierarchy, priesthood, and "well instructed laity of the Dominion" do not support the League.

${ }_{22}$ Michael Cottrell, "John O'Donohoe and the Politics of Ethnicity in Nineteenth-Century Ontario," 73.

23 Nicholas Flood Davin, The Irishman in Canada, (London: Sampson Low, Marston \& Co.; Toronto: Maclear and Company, 1877), 659; Globe (Toronto), 8 December 1902, p. 12, col. 1. 
occupied a "prominent place in the foremost rank of those Irishmen, who, adopting Canada as their home, and closely identifying themselves with her manifold interests, have, through the exercise of industry, perseverance, and personal integrity, attained to considerable and well-deserved eminence." ${ }^{24}$ Indeed, O'Hanly referred to O'Donohoe as "the architect" of the Catholic League who demonstrated "zeal, devotion, and patriotism" and promoted the amelioration of the Irish "in this colony and elevating them to that position to which their numbers and intelligence so justly entitle them." 25

Frank Smith was also instrumental in the founding of the Catholic League. Smith was born in Armagh in 1822, and emigrated to Canada with his widowed father in 1832 , settling near Port Credit. Beginning his career as a clerk, Smith would soon take ownership of a general store. Soon after, Smith moved to London and opened a retail grocery store, Frank Smith \& Co. Smith would have a successful career as a businessman and politician, being president of the Dominion Bank, the London and Ontario Loan Company, and the Toronto Street Railway Company. He was also Vice President of the Consumers' Gas Company, the Dominion Telegraph Company, and a director of the North American Life Company. Like O'Donohoe, Smith was a Liberal who would become a prominent politician as an Alderman and Mayor of London. ${ }^{26}$

During the 1869 St Patrick's Day celebration in Toronto, O'Donohoe took to the stage to proclaim that the political weakness of the Irish impeded their success. ${ }^{27}$ Referencing the unjust arrest of Irish Catholics in the wake of the Fenian Raids, O'Donohoe asserted that the

24 The Canadian Biographical Dictionary and Portrait Gallery of Self-Made Men, Ontario Volume, (Chicago, New York, and Toronto: American Biographical Publishing Company, 1880), 354.

25 John Lawrence Power O'Hanly, The Political Standing of Irish Catholics in Canada, A Critical Analysis of its Causes, With Suggestions for its Amelioration, CIHM 23746, iv.

26 Globe (Toronto), 18 January 1901, p. 7, cols. 1-3; Rev. William Cochrane, The Canadian Album. Men of Canada; or Success by Example in Religion, Patriotism, Business, Law, Medicine, Education and Agriculture, Vol. 1. (Bradley, Garreston \& Co.: Brantford, Ontario, 1891), 324.

27 Michael Cottrell, "John O'Donohoe and the Politics of Ethnicity in Nineteenth-Century Ontario," 74. 
Irish as a body ought to stand united in order to demand their rights in Canada. ${ }^{28}$ Smith and O'Donohoe were the leaders of the League at its inception and Patrick Boyle's Irish Canadian was the press organ through which the news and ideas of the League were disseminated, that publication having a large Irish readership. In anticipation of the 1872 elections, a circular of August 1871 announced the intended formation of the Catholic League. The brochure asserted that though the Catholics of Ontario were called upon in common with their fellow-subjects of every denomination to bear their proportion of the expenses of the government, and were affected in every way by the laws enacted, they were "almost totally unrepresented in the halls of the Legislature." 29 This ostracism necessitated the formation of the organization. ${ }^{30}$

The rhetoric and discourse of the Catholic League presented the organization as a lobby group for collective action on the part of the Irish Catholics of Ontario. To achieve unity, the League was carefully ambiguous about party allegiance. It framed itself as the voice of Irish Catholics and mobilized on issues related to Irish Catholic representation in the liberal state apparatus. The first object of the League, the Irish Canadian noted, was "fair representation of Catholics in the Provincial and Dominion Parliaments, and that places or positions are but secondary objects." The places or positions would follow, they argued, "if Catholic members were representatives in the Legislative halls of the country." Asserting that the Catholic League "has no politics" they called upon Catholics of Ontario to "join the league if you would hold the position to which you are entitled.” They concluded this injunction proclaiming, "until Catholics are united, and decide on the policy to be pursued, let party and politics be merged, and our sole and only motto be 'Union-Unite! Unite!!

28 Irish Canadian (Toronto), 24 March 1869; Michael Cottrell, "John O'Donohoe and the Politics of Ethnicity in Nineteenth-Century Ontario," 75.

29 Irish Canadian (Toronto), 27 January 1875, p. 4, col. 4.

30 Irish Canadian (Toronto), 9 August 1871, p. 4, cols. 1-3. 
Unite!!!"31 This editorial in the Irish Canadian illustrates an important principle of the Catholic League. It showed clearly that they were not arguing for a meritocratic civil service. They felt that if elected, Catholic politicians would make sure Irish Catholics would get a fair share of patronage appointments whatever party emerged victorious.

Along with O'Donohoe, the executive committee of the Toronto branch of the League was made up of John Shea, first vice-president; Dr M. Lawlor, second vice-president; J.D. Merrick, secretary; Jeremiah Murphy, assistant secretary; and Eugene O'Keefe, treasurer. ${ }^{32}$ In late 1871, O'Donohoe and other members of the Toronto executive went on a campaign across cities and towns in Ontario holding preparatory meetings to promote the formation of League branches. There was power in numbers, argued the Irish Canadian, urging the Catholics of Ontario to form a branch of the League even if there were "but ten men in any township of village in Ontario...the mere fact of your doing so trebles your political power at once, and your influence and vote will be courted where now you are neglected or despised by Parliamentary aspirants. ${ }^{{ }^{33}}$ In September 1871 a preparatory meeting was held in St Catharines. That evening, speakers including O'Donohoe and John McKeown of Hamilton asserted that the necessity was a result of the past treatment of the Catholics in Ontario. Dr Michael Lawlor attributed the exclusion of Catholics to the "naive modesty of the Irish." If they did not ask for anything, Lawlor argued, they could not expect to have positions forced upon them. However, now the Irish Catholics of Ontario "had made up their minds to have their rights, and if they were only true to themselves, no government or political party could keep them from getting" those rights. The executive committee of the League's St Catharines branch was elected and the "large and influential gathering of the most intelligent and

\footnotetext{
Irish Canadian (Toronto), 6 September 1871, p. 4, cols. 2-3.

Irish Canadian (Toronto), 10 April 1872, p.4, col.3.

Irish Canadian (Toronto), 17 April 1872, p.4, cols.1-2.
} 
influential Roman Catholics of the town" were all enrolled as members of the League. ${ }^{34}$

In October 1871 a similar meeting was held to consider the advisability of opening a branch in Hamilton. A provisional committee was elected, ${ }^{35}$ and O'Donohoe and other Toronto representatives John Mulvey, J.D. Merrick, and A.P. Devlin explained in some detail the objectives and merit of the Catholic League. In a "very forcible and eloquent" speech that lasted over an hour O'Donohoe laid out the case for the league. He repudiated opponents who saw the League as hostile to "the rights or privileges of their Protestant fellowsubjects." Rather, O'Donohoe explained, the purpose of the League was to make sure that Catholics of Ontario "get fair play and nothing more," and argued that they should not be ostracized because they were Catholics. He asserted that the Catholics of Ontario numbered one-fifth of the population, and bearing this in mind it was strange that "in all public offices and positions they were almost totally ignored, except in the position of menials." This exclusion was through no fault of their own, O'Donohoe continued, and thus it must be asked why did this exclusion exist? That was the question O'Donohoe and the Catholic League sought to solve. In doing so, he made it clear that he wished party politics to stay out of the discussion. O'Donohoe urged upon the meeting "the great necessity of united political action for the future and hoped that those who would join the league would lay aside all personal considerations and do their duty, and for his part he would do his.” This nonpartisan spirit was echoed by the next speaker, J.D. Merrick, a Conservative, who spoke of his past political opposition to the Liberal O'Donohoe. But, he continued, when he saw what Catholics had received for past political support, "he came to the conclusion that there ought to be a change, and that change, whatever it might be, could not be for the worse."36

\footnotetext{
Globe (Toronto), 28 September 1871, p. 2, col. 2. Globe (Toronto), 24 October 1871, p. 4, col. 5.

Irish Canadian (Toronto), 25 October 1871, p.5, col. 2.
} 
The change Merrick referred to was the pragmatic shift the League was attempting to make in the voting habits of Irish Catholics from Conservative to Liberal. ${ }^{37}$ League members argued that the support that Irish Catholics had given to the Conservatives had not paid off as they failed to see any benefit. Boyle and the Irish Canadian later explained that prior to the League's establishment the overwhelmingly majority of Catholics "acted with the Conservative or Tory party, and through this support the Conservative party held a long lease of power." But Conservatives, Boyle continued, preferred to exercise this power "within their own charmed circle - the Orange body." 38 The change required for Irish Catholics to secure their fair share in Ontario, then, meant abandoning support for the Conservatives and aligning with the Liberal Party.

The call for a shift in Irish Catholic voting habits worried the Conservatives, and to combat this the editors of Toronto's Mail began to publish extracts of some of Liberal leader George Brown's most abusive articles denouncing Catholicism in order to remind Irish Catholics who they would be supporting by voting for the reformers. Boyle and the Irish Canadian responded that Globe passages published by the Mail were originally written in the early 1850 s but were reprinted in order to have "us believe that the Mr. Brown of 1853, 4 and 5 is the same Mr. Brown of to-day." Boyle argued that it was "palpable to the merest school-boy that the Globe is somewhat altered in its tone, and that Catholics now get the

37 David Shanahan has argued that the Catholic League was a tool of the Liberals from the start. While it originated as an association that dedicated itself to convincing Irish Catholics to vote for the Liberals, there were some Conservative Irish Catholics, like John O'Connor, who were members of the League. They believed that the Irish needed a united voice and felt that the League would operate as a non-partisan ethnic voting block. Seeing that this was not in fact the case, O'Connor and other Conservatives left the League prior to the 1872 elections, which is an issue that will be explored in greater depth below. Whether the League was ever a non-partisan organization, or whether these Conservatives had been fooled by the Liberal leaders of the Catholic League, or whether they joined the League with the intention to sabotage it and its Liberal support, is unknown. In any event, there were Liberal and Conservative elements in the League until 1872.

38 Irish Canadian (Toronto), 27 January 1875, p. 4, col. 4. 
same measure of fair play in its columns, as is granted to their Protestant fellow-citizens." 39

Boyle went on to ask what group had been most aggressive in hounding Irish Catholics during the Fenian scare of 1866, when to be a Catholic "was to be looked upon as a Fenian or a sympathizer." Certainly not George Brown and the Reformers, Boyle thundered. Rather, the "worst enemies the Catholics had were John A. Macdonald and his followers - the Orange clique of Ontario-who suspended the constitution to fill the prisons of the country with persons whose only crime was their Catholicity and their Irish nationality." Macdonald and the Conservative Party, Boyle continued, "cared nothing about the hardships and trials they imposed upon Irish Catholics, whom they used and abused as the very outcasts of society...unworthy of being protected by the safeguards of the constitution." 40 Thus, the change spearheaded by the Catholic League was to create a united Irish Catholic voting block against Macdonald and the Conservatives.

Following a series of preparatory meetings to form branches throughout the province, the first official meeting of the Catholic League took place on 8 December 1871 at the home of Frank Smith. Other notable Irish Catholics present at this initial meeting included O'Donohoe; J.D. Merrick, merchant; James Stock, merchant; Patrick Hynes, alderman; John Carroll, contractor; Thomas McCrosson, merchant; John O'Connor, M.P.; Richard W. Scott, M.P.P.; and John McKeown, barrister. Those in attendance represented a wide swath of Ontario, from Toronto, Hamilton, Guelph, Brockville, and Ottawa. The meeting adopted several resolutions, and observed that though these individuals had acted on different sides in past political contests, they were unanimously agreed that Catholics should unite and make a determined effort to secure just representation. ${ }^{41}$

\footnotetext{
Irish Canadian (Toronto), 19 June 1872, p. 4, col. 1. Ibid.

Globe (Toronto), 21 June 1872, p. 2, col. 5.
} 
The Catholic Church supported the League, at least in a general sense. At the initial meeting of the League in December 1871 it was agreed that a committee of Smith, O'Donohoe, and John O'Connor would present an address outlining the objects of the Catholic League to the Bishops of Ontario. Archbishop Lynch was initially cool to the idea of the League. Given Lynch's close relations with Macdonald and the Conservatives, his lukewarm response to the establishment of a reform-oriented political association is not surprising. But by the early 1870s, Lynch accepted the necessity of the League and the potential benefits it had for the community. ${ }^{42}$ After consultation among the bishops, Archbishop Lynch sent a letter to the committee formally communicating that the hierarchy approved of the League and would support the united action of the Catholic body. ${ }^{43}$ Writing to Frank Smith in February 1871, therefore, Lynch gave his approval to the formation and activities of the Catholic League, saying that while he led the Irish Catholic community in all matters concerning faith and religion, he did not "pretend to guide them in politics." John O'Donohoe later affirmed that the League was founded to condemn exclusion, and not to combine for religious purposes and because of this it had received the approval of the Catholic hierarchy of Ontario. ${ }^{44}$ Lynch did not place his support behind the Catholic League, however, owing to that organization's ties with the Liberal party, which Lynch felt had ignored Catholic interests as much as the Conservatives. Lynch agreed that for years the majority of Catholics of Ontario found themselves excluded "with hardly any exceptions" from participation in government offices "by every succeeding administration, whether Liberal or Conservative.” Thus, as an Irish Catholic “citizen” Lynch more than readily approved of the formation of a "league for self-protection and advancement." At a general

42 Michael Cottrell, "John O'Donohoe and the Politics of Ethnicity in Nineteenth-Century Ontario," 75.

43 Globe (Toronto), 21 June 1872, p. 2, col. 5.

${ }^{44}$ Irish Canadian (Toronto), 13 June 1877, p. 5, cols. 2-3. 
level, the Catholic League received his support as a political organization aiming for the advancement of Irish Catholics. However, Lynch was careful not to directly support the Liberal bent of the League owing to his own Conservative leanings. Unable to ignore the situation on the ground, however, Lynch did give tacit approval of the Catholic League saying that after long experience Irish Catholic "support and patience" with the Conservative government had been "ill-rewarded." 45

\section{Systemic Discrimination and a Liberal Governmentality}

As Protestants dominated nineteenth-century Canadian society and the liberal order, Irish Catholics viewed the patronage system as one in which Protestant governments kept Protestant clients close while excluding the Irish Catholic community. The Catholic League aimed to show the Irish Catholic community how its members had been systemically ignored by the established power with respect to patronage appointments, and to mobilize them to create political change. The Catholic League presented examples of anti-Irish Catholic discrimination and Irish exclusion from the liberal state in order to mobilize their community into action. Catholic League members recognized that the climate of opinion on appointments was shifting and couched their rhetoric in the language of liberalism and scientific progress. Pending the establishment of a meritocratic bureaucracy and rational state, however, they intended to act in their own self-interest.

To bolster their case about how Conservatives were unfairly treating Irish Catholics and why the community should vote Liberal, in 1872 League supporter J.L.P. O'Hanly published a paper entitled "The Political Standing of Irish Catholics in Canada." ${ }^{\text {" }}$ What is

45 ARCAT, Archbishop Lynch Papers. LAF0221, 17 February 1872, Lynch to Frank Smith.

46 John Lawrence Power O'Hanly, The Political Standing of Irish Catholics in Canada, A Critical Analysis of its Causes, With Suggestions for its Amelioration, CIHM 23746. 
interesting about this work is its focus on the patronage issue. While the speeches of O'Donohoe and Smith and the editorials of Boyle were about political representation, O'Hanly's work instead highlighted a consequence of such under-representation, which was the lack of Irish Catholic political appointments. Given that O'Hanly was a surveyor and engineer, largely reliant upon government contracts for employment, this issue was likely close to his heart. Indeed, O'Hanly wrote employment requests to Macdonald, and in one letter expressly remarked that "my countrymen and co-religionists complain that we (Irish Catholics) are denied a fair share of public appointments, particularly in higher offices. I am of those who have always held that that complaint was well-founded." 47

In this pamphlet, which was funded by the Liberal Party under the auspices of the Catholic League, ${ }^{48} \mathrm{O}^{\prime}$ Hanly reviewed the treatment of Irish Catholics by governments during the union period. This era was marked by the political struggles between conservatives and reformers in the decades following the Rebellions and Durham. O'Hanly accused the Conservative Party of discriminatory treatment toward Irish Catholics with respect to patronage positions. Prior to the Civil Service Act of 1882, which established a threemember board of Civil Service examiners to supervise exams for appointments and promotions, the early years of the public service were marked by patronage as newly elected governments typically fired large numbers of civil servants employed by the previous government and hired their own people. While O'Hanly argued that this system was generally corrupt and kept Irish Catholics out of positions of power, he believed that the Conservatives predominated in such discrimination.

He argued that there was once no dishonour in being an Irish Catholic and their

47 LAC, John A. Macdonald Collection, MG26 A, Reel C1752, Volume 377, pp. 176094 to 176097, J.L.P. O'Hanly to Macdonald, October 14, 1881.

48 LAC, O'Hanly Papers, MG 29 B11, Vol. 1, File 1, Mackenzie to O'Hanly, 25 July 1872. 
political standing was second to none other. ${ }^{49}$ He pointed out that the progressive measures such as municipal institutions, secularization of the clergy reserves and extension of the franchise were products of the Baldwin and Hincks administrations of 1848-54. But supporting their "hereditary foe" (the Conservatives) because of their electoral victories and control of patronage had allowed them to be taken for granted over the past 18 years and systemically discriminated against. ${ }^{50} \mathrm{O}^{\prime}$ Hanly argued that the once crucial place of Irish Catholics began to erode and he suggests that the change took place after 1854, when the "party ... coalesced with the Tories of Upper Canada", an allusion to the LiberalConservative coalition of moderate reformers and moderate Tories under Macnab and then Macdonald. ${ }^{51}$ The influence of the Tories in that coalition put the party at the mercy of the Orangemen. Meanwhile, Quebec prelates, certain that the Liberals would dismantle the Catholic Church in Quebec, convinced the Irish bishops in Canada West to support the Conservatives with them. ${ }^{52}$

O'Hanly noted that since 1854, 495 first-class appointments to positions in the government administration had been made. Of these, the Conservative Party conferred 455, while the Liberal Party conferred 40 during their time in power from May 1862 to March 1864. Of the 455 appointments made by the Conservatives, O'Hanly observed, nine went to Irish Catholics which resulted in a ratio of about one in fifty. Of the 40 appointments given by the Liberal Party, four were to Irish Catholics, which comes to a ratio of approximately one out of ten.

In Quebec, where O'Hanly noted one would expect a greater proportion of Irish Catholics in positions of social power owing to the Catholic fact, the numbers of Irish

49 O'Hanly, The Political Standing of Irish Catholics in Canada, 48.

50 Ibid., 49.

51 Ibid., 54.

52 Ibid., 55. 
Catholics in both administrative positions and elected positions were equally low. Of the 178 legislators in the province of Quebec, asserted O'Hanly, eight were Irish Catholic while 45 were Protestant. One might imagine that the high number of Protestant legislators resulted from the Protestant population of Quebec voting in a co-religionist rather than a French or Irish Catholic. However, O'Hanly asserted that an Irish Catholic represented not a single constituency where the French element predominated. He did note, though, that "many such are represented by Protestants." ${ }^{53}$ The antipathy O'Hanly believed French Catholics felt toward Irish Catholics stemmed from the influence of George Cartier and the Conservative Party. "My countrymen," O'Hanly wrote, were "systematically ignored and sneered at by Sir George Cartier, Protestant Englishmen preferred to them and raised over their heads."54 O'Hanly wrote this paper on the political standing of Irish Catholics for the Catholic League in Toronto, and it was delivered to its president John O'Donohoe. Bearing in mind this audience, O'Hanly would have been unlikely to critique that bastion of Conservative politics in Quebec, the Catholic Church. Nonetheless, O'Hanly made the case for the discriminatory treatment faced politically by Irish Catholics across Canada, even in a Catholic province.

William Smyth has argued that the fact that Catholics held less than six percent of the offices analyzed by O'Hanly substantiates his claim of structural under-representation. Moreover, Smyth observes, had O'Hanly's analysis included salary levels the data would have been more extreme, as many Catholics in government employment were in positions of clerks or messengers. ${ }^{55}$ Indeed, John A. Macdonald's defence, communicated to Archbishop Lynch in 1869 , was that while he was doing all he could to give Catholics their fair share of public employment, and Catholics were capable of holding middle and lower offices, their

53 Ibid., 34.

54 Ibid., 35.

55 Smyth, Toronto, the Belfast of Canada, 127. 
low educational standards limited their suitability for higher offices. ${ }^{56}$ O'Hanly countered this by arguing that undue Orange influence in the Conservative Party, not low education levels, kept Irish Catholics out of positions of influence. ${ }^{57}$

O'Hanly believed discrimination extended into economic sectors as well, and dealt with what he believed were systemic barriers to Irish Catholic social mobility. In an unpublished paper articulating his views on relations between Catholics and the nativist Protestant Protective Association, ${ }^{58}$ he argued that Protestants controlled the economy of Ontario, and "rigidly excluded" Catholics from employment. He remarked upon the lack of Catholics working in the economic fields of manufacturing and mercantile industries, in the transport services, the professions, and municipal corporations. Also because Protestants controlled banks, loan and savings societies, and insurance companies, O'Hanly observed that Catholic employees were scarcely to be found as managers, agents, or in similar positions of trust. Catholic barristers and Catholic physicians, argued O'Hanly, existed because of Catholic clients. "Show me the Protestant clients of a Catholic barrister...count me the Protestant patients of a Catholic physician?"59 asked O'Hanly. And, perhaps closest to his situation as a Catholic civil engineer, O'Hanly thundered, “civil engineers are almost wholly dependent for employment on the great moneyed interests. Hence Catholic engineers have practically no standing." 60

O'Hanly believed the Liberal Party best represented the interests of Irish Catholics, and argued that Irish Catholics were indebted to the "liberal element" in society for

56 ARCAT, Archbishop Lynch Papers, AE02/21, 17 July 1869. Quoted in Smyth, Toronto, the Belfast of Canada, 125.

57 O'Hanly, The Political Standing of Irish Catholics in Canada, 55.

58 The Protestant Protective Association was a Protestant association linked to the Orange Order. P.P.A. In Ontario: History and Principles of the Organization, 1894. CIHM 25285.

59 LAC, O'Hanly Papers, MG 29 B11 Volume 18, File 9, "Protestant Protective Association and Catholics," Undated. This is a later document but one consistent with his earlier views about Orange influence.

60 Ibid. 
dismantling discriminatory political and economic structures. O'Hanly asserted that Irish Catholics could thank the Liberal Party, individual liberals, and reformers in Canada for responsible government, for municipal institutions - which gave people control over their local taxation - for the secularization of the clergy reserves, and for the extension of the elective franchise. ${ }^{61} \mathrm{O}^{\prime} \mathrm{Hanly}$ went on to argue that liberals "in this as well as in every other country" are to be thanked "for every legislation that distinguishes a free people from an enslaved people." ${ }^{62}$ O’Hanly credited small-1 as well as large-L liberals for advancing policies that promoted individual liberty.

O'Hanly made use of the rhetoric of liberalism and rational government even as he argued in favour of the apparent irrationality of ethno-religious block voting. He argued the point that self-government made one fit to govern others, a key plank in Foucault's notion of liberal governmentality. ${ }^{63}$ The goal of the Catholic League, O'Hanly argued, was to educate its members in the fundamental principles of self-government ${ }^{64}$ so that individuals, "under the influence of natural laws, directed by reason, will gravitate toward congenial parties." 65 Irish Catholics, O'Hanly continued, are "intuitively liberal" 66 and he claimed that his race "are sincere, fervent friends of constitutional liberty, human progress, and religious toleration," - in favour of secret ballot, householder franchise, an elected Senate, and "cheap, economical government." ${ }^{67}$ With principles "liberal and progressive" their choice of

${ }_{61}$ O'Hanly, Political Standing, 38.

62 Ibid., 39

63 Michel Foucault, "Governmentality," in The Foucault Effect: Studies in Governmentality, edited by Graham Burchell, Colin Gordon, and Peter Miller, (Chicago: University of Chicago Press, 1991), 91; Bruce Curtis "After 'Canada': Liberalisms, Social Theory, and Historical Analysis," in Liberalism and Hegemony: Debating the Canadian Liberal Revolution, edited by Jean-Francois Constant and Michel Ducharme, (Toronto: University of Toronto Press, 2009), 188.

65 Ibid.

66 Ibid., iv.

67 Ibid., 49. 
representatives should be obvious. ${ }^{68}$ O'Hanly invoked the scientific method, and the rational gathering of statistical data, a liberal technology of government, as characterizing his method and his analysis. He viewed himself as a scientist who rationally established a mean of all his observations rather than being swayed by a single observation. ${ }^{69}$ He claimed that collating statistics over 20 years established a rational basis for preferring the Liberals over the Conservatives.

O’Hanly's invocation of political and social liberalism was, in part, a strategy to help the Irish Catholic population of Canada. But it also recognized that public discourse was shifting toward rational and meritocratic principles, ${ }^{70}$ and as outlined in the last chapter, O’Hanly was a genuine Victorian liberal in his beliefs. He argued that there existed in Canada "a heterogeneous mass composed of all races and all religions," and reasoned that the aim of society should be "to blend them all into one unified community...merged in a Canadian identity." In such a nationality political distinctions of religion and ethnicity would not matter. He argued that "no friend of his country can desire the perpetuation of politicoreligious societies," and that it is harmful to govern according to such principles and that only "in extreme cases" and for "temporary purposes" should a minority resort to it. "Th "There is none less worthy of your support," O'Hanly advised, "than he who claims it solely on religious grounds. He should also have other passports to your favour. He should have education, he should have ability, in a word, he should have a record to point to."72 But he felt that this kind of unified future was unlikely in a Canada governed by Conservatives who discriminated against Irish Catholics. ${ }^{73}$ Observing that "we must deal with the world as we

\footnotetext{
Ibid., 50.

Ibid., 53.

Banoub, "The Patronage Effect," 32.

O'Hanly, Political Standing, iii-iv.

Ibid., 58.

Ibid., 7-9.
} 
find it," ${ }^{\prime 74}$ he argued the need for collective action against Conservative appointees, who were not characterized by the liberal values of "education, enlightenment, moderation and efficiency" but were "Orangemen of the most violent and ignorant class" discrimination hurt Irish Catholics, argued O'Hanly, as well as all of Canada. Because "each class contributes to the revenues more in proportion to numbers than any arbitrary social classification," and the numbers of Irish Catholics in Canada were substantial, then Irish Catholics contributed greatly to the state's revenues. ${ }^{76}$ However, the paucity of Irish Catholics in administrative positions made this group feel socially inferior. O'Hanly reasoned that individuals would feel more at ease when their interests "are in the keeping of their brethren than in the hands of strangers." 77

This strategy was accepted by other Catholics advocating for greater Catholic representation in patronage appointments. For instance, in an 1870 letter from the Vicar General of Arichat James Quinan, the author first opines that he believes religion should not enter into the question of appointments, saying that a man's religion should be neither a qualification nor a disqualification for an appointment. However, Quinan goes on to assert that Catholic judges needed to be appointed because they had been systemically excluded because of Nova Scotia's "bigoted majority."78 This is an important example of a Catholic accepting the ideal of "the impartial bureaucratic state" based on ability and merit, but seeing religiously-based appointments as necessary to achieve greater balance till that neutral ideal can be achieved.

Columns in the Irish Canadian echoed the views put forth by O'Hanly and mirrored

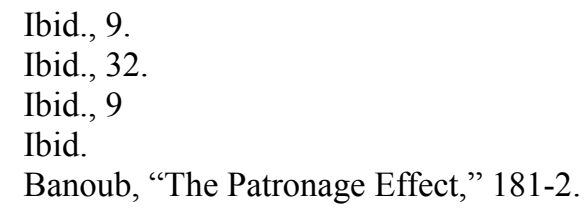


the strategy espoused by Quinan. In an editorial in the 6 September 1871 edition of the paper, it noted numerous examples of civil service employees who were given their positions not because of their fitness for the position, or their prior attainments, nor their urbanity or high moral tone. Instead, they argued, individuals were given appointments because they were Orangemen and the lodges demanded it: "there were able and respected men, candidates for the office, who had the recommendation" but this was of no use in the face of Orange influence over Macdonald's government. ${ }^{79}$ Thus this advanced the view that Irish Catholics met the qualifications for appointment on merit but were excluded out of ethnoreligious prejudice.

\section{Political Fractures Within the Irish Catholic Community}

Though presenting themselves as a united Irish Catholic voice seeking to ameliorate the disadvantaged position of their community within Canadian liberalism, the Catholic League was an organ of the Liberal Party. Irish Catholics like O'Donohoe, Boyle, and O'Hanly were staunch reformers and opposed the Macdonald government, and those in the Liberal Party recognized the potential of the Irish Catholic vote and so courted the ethnic vote in an attempt to wrest political power away from the Conservatives. The move to the Liberals alienated Conservative Irish Catholics who initially supported the Catholic League, such as John O'Connor. Moreover, in 1871 John A. Macdonald made a calculated decision to split the Catholic League vote by naming League members O'Connor and Frank Smith to the positions of Minister of Inland Revenue and the Senate respectively. ${ }^{80}$

A Conservative, O'Connor was born in Boston, Mass., in 1824, after both of his parents emigrated from Ireland in 1823, the family originating from Kerry. In 1828, the

79 Irish Canadian (Toronto), 6 September 1871, p. 4, col. 2-3.

80 Globe (Toronto), 5 March 1873, p. 1, col. 9. 
O'Connors moved to a Catholic community in Essex County in Upper Canada. A successful student, O'Connor was admitted to the bar of Upper Canada in 1854 and was made a Queen's Counsel in $1872 .{ }^{81}$ As barristers tend to do, O'Connor entered the political arena and was elected for the Conservatives in the dominion elections of 1867 in Essex. O'Connor held various positions in government throughout the 1870s, including president of the Privy Council, minister of inland revenue, and postmaster general. He was defeated in the 1874 election, at which point he left Essex and moved to Ottawa, where he established a legal practice. He was elected president of the St. Patrick's Society of Ottawa in 1875 and acted as chairman of Ottawa's O'Connell Centennial Celebration. O'Connor would go on to serve as a judge on the High Court of Ontario Justice until his death in $1887 .{ }^{82}$ Given his Conservative credentials, placing $\mathrm{O}^{\prime}$ Connor in the government was a relatively effortless move on Macdonald's part. Smith, on the other hand, was a more difficult manoeuvre. Macdonald had been wooing the Liberal Smith since at least 1867, because of his success and influence among the Irish population. ${ }^{83}$ Given Smith's central role in the Liberal Catholic League, his appointment as a Senator in Macdonald's administration was an enormously successful coup for the Prime Minister. As David Shanahan argued, Macdonald was concerned that frustrated Irish Catholics who supported the Catholic League would vote Liberal, and he thus wanted to install Irish Catholics in his cabinet to demonstrate his goodwill to that body of the population and to sow disunity among the League leaders. ${ }^{84}$

81 The Canadian Biographical Dictionary and Portrait Gallery of Self-Made Men, Ontario Volume, 266.

82 Information of O'Connor taken from his biography on PARLINFO, last accessed 4 March 2014, http://www.parl.gc.ca/Parlinfo/Files/Parliamentarian.aspx?Item=715c07ae-d21b-4608-b9c3cab810f535ba\&Language=E\&Section=ALL, as well as LAC John O'Connor Fonds, MG27-ID13.

83 Mark McGowan, "SMITH, Sir FRANK," in Dictionary of Canadian Biography, vol. 13, University of Toronto/Université Laval, 2003-, accessed March 1, 2016, http://www.biographi.ca/en/bio/smith_frank_13E.html.

84 Shanahan, "The Irish Question in Canada," 30; LAC, James F. Kenny Fonds, MG 30 C176, Macdonald to Moylan 16 February 1871; The Conservative Macdonald also attempted to link the Liberal Catholic League to Fenianism. LAC, John O'Connor Fonds, MG 27 I D13, Macdonald to O'Connor, 26 December 1870; David Shanahan, "The Irish Question in Canada," 29. 
That strategy seems to have been successful. Prior to the 1872 elections, O'Connor and Smith, along with Dr. Michael Lawlor, the secretary of the executive and chairman of the St Patrick's Ward Branch of the Catholic League, Alderman Patrick Hynes, chairman of the St David's Ward Branch of the Catholic League, John Cosgrave, secretary of the St Andrew's Ward Branch of the Catholic League, and William A. Lee, secretary of the St Patrick's Ward Branch of the Catholic League and a number of other Conservative Irish Catholics, signed a letter of protest and announced their withdrawal from the society. ${ }^{85}$ They had initially supported the League, as they felt that a union of Irish Catholics mobilizing for fair representation was necessary. However, they had soon begun to feel that the League was less of an organization of Irish Catholics and more an organization of Liberals. They opposed the "bad faith and factionalism" of the League, as well as what they perceived to be its failure to unite Irish Catholics, arguing that instead it had brought about disunion and discord. They announced their withdrawal from all connections with the League, and urged all those who had joined the organization to also sever their association "with the men whose manifest aim is to wheedle the Catholics of Ontario into a political alliance with George Brown." $" 86$

In response, the Catholic League charged that O'Connor was attempting to bring the League "into the arms of conservatism," in "utter disregard of Catholic interests." ${ }^{87}$ At a meeting in June 1872, O'Connor was censured by the League for his "unmanly conduct towards the Catholic League of the Province of Ontario." An editorial attacked O'Connor in the Irish Canadian for attempting to shift the League to Macdonald and the Conservatives

85 Globe (Toronto), 21 May 1872, p. 3, col. 1.

86 Irish Canadian (Toronto), 15 May 1872, p. 5, col. 1.; Cottrell notes that the Conservative members of the society were expelled from the League, rather than leaving under protest. In any case, by 1872 the Catholic League was overtly supporting the Liberal Party. Michael Cottrell, "John O'Donohoe and the Politics of Ethnicity in Nineteenth-Century Ontario," 77.

87 Irish Canadian (Toronto), 3 July 1872, p. 5, col. 2. 
without a pledge or promise that Catholic demands would be listened to, "or that any effort would be made, by recognition or otherwise, to better the condition of the Catholic body in the Province of Ontario." ${ }^{88}$ In assailing O'Connor, the Irish Canadian made it clear that the League was committed to the Liberal Party because of its pledge to improve the standing of Irish Catholics in Ontario, an assurance the Conservatives were unwilling to make. For the Catholic League, then, the Liberal Party was the "party of justice and progress." 89

The partisan contour of the League merged with the ethno-religious rhetoric of the Irish Catholic population, in what can only be described as an early form of identity politics. The message imparted was to support the Liberals because they would support Irish Catholics. Assailing O'Connor because of his opposition to the League's Liberal politics was thus framed not in terms of party allegiance, but in terms of the Conservative Party's lack of allegiance to Irish Catholics. A significant part of the Irish Catholic electorate voted for Macdonald's government in 1872, and that election saw many Catholic candidates defeated at the polls, including O'Donohoe. Catholic League members blamed the loss less on Orange Protestants, the original target of the League's attacks, than on Conservative Catholics like O'Connor and Smith who worked to undermine the League's legitimacy and impact.

Despite the setback in the 1872 elections, an editorial in the Irish Canadian lauded the aims of the organization as advancing the collective cause of the Irish Catholic population of the province. ${ }^{90}$ Irish Catholics had acted in an important role in those elections, it asserted, and were roused from their apathy by the Catholic League's call to action. The Irish Canadian urged the continuation of the League until Irish Catholics were in every respect treated equally. However, Boyle was distressed that Smith received a senate

8 Irish Canadian (Toronto), 12 June 1872, p. 4, cols. 2-4.

89 Irish Canadian (Toronto), 28 September 1872, p. 4, col. 3.

90 Irish Canadian (Toronto) 28 September 1872, p.4, col.1. 
appointment as a Liberal-Conservative following his defection to Macdonald's camp. Boyle called this nothing more than political self-interest and placed Smith alongside other notable Irish Catholics who had defected to the Conservatives and exchanged their duty to Irish Catholics for political glory. Boyle asserted that Macdonald never gave a Catholic "any position but at the expense of his independence-McGee, Moylan and Smith attest the fact." ${ }^{91}$ A letter writer from Guelph advanced a similar perspective, blaming the failure of the League on certain leaders who "preferred to abandon the cause and accept the positions that were offered them by the Government," a clear reference to Frank Smith. ${ }^{92}$

In a sense it was ironic for Boyle and Catholic League supporters to attack O'Connor and Smith for their support of the Conservatives. After all, they were both now in Ottawa, able to act on behalf of the Irish Catholic community. In a letter to Irish Conservative Moylan, Macdonald observed that he made Frank Smith a senator as "a sort of Irish Catholic representative in that branch of the legislature and John O'Connor acts in the House of Commons. ${ }^{93}$ Were Boyle's own recriminations toward O'Connor and Smith nothing more than his own political self-interest? The extent to which the Catholic League was a political organization or an ethno-religious one can certainly be considered. It was the threat of a mass Catholic voting block that caused Macdonald to sway Smith to the Conservatives, thus paving the way for Smith to become a senator. In this position, Smith did indeed advocate for Irish Catholic rights. Under his advisement, Macdonald agreed to release Fenian prisoners to increase and maintain support for the Conservatives among Irish Catholics, he secured patronage positions for Irish Catholics, as well as securing government funds for the

91 Irish Canadian (Toronto), 28 September 1872, p. 4, col. 2; The Irish Catholic Conservative supporter and editor of the Canadian Freeman, James G Moylan, was given the job of Governor of Kingston Penitentiary in 1872, Shanahan, "The Irish Question in Canada," 30.

92 Irish Canadian (Toronto) 23 June 1875, p. 5, col. 2.

93 LAC, Moylan Fonds, MG 29 D15, Macdonald to Moylan 18 February 1871. 
running of Boyle's Irish Canadian, an act which went a long way toward repairing the damaged relationship between the two adversaries. ${ }^{94}$ Yet for Boyle and other members of the League, it seemed more important that an Irish Catholic Liberal be elected than an Irish Catholic Conservative with Macdonald's ear.

The Catholic League continued to play the ethno-religious card. Support for the League's candidates from the wider society depended on political affiliation. This was the case with respect to the Globe's support for O'Donohoe in the 1874 elections. Though O'Donohoe initially won the 1874 election in the riding of East Toronto against Emerson Coatsworth $\mathrm{Sr}$, that victory was later declared void, as it "had come to Mr O'Donohoe's knowledge that persons acting in his interest had violated the law," 95 engaging in bribery and intimidation during the campaign. ${ }^{96}$ The Reformist Globe, which had thrown its support behind the Reform-minded O'Donohoe throughout the campaign, maintained that support, asserting that the Reformers of East Toronto ought "to organize themselves forthwith in order to secure Mr. O'Donohoe's re-election.” The paper cited O'Donohoe's qualifications for election as a Liberal, as well as the fact that he represented the Irish Catholic population of the riding. That population, the Globe argued, "have long demanded representation by one of themselves, and too often have desired it in vain." Throughout the campaign, they defended O'Donohoe against accusations of Fenian sympathies and charges that he was nothing more than a tool of the Ultramontane clergy. ${ }^{97}$ Nevertheless, O'Donohoe would go on to lose the re-contested election by over 400 votes to Samuel Platt.

Shanahan argues that the 1872 defection of Smith and O'Connor destroyed the credibility of the League and that the Liberals' attempt to gain the Irish Catholic vote failed

94 LAC, John O'Donohoe Fonds, MG 27 I E12, Macdonald to O'Donohoe, 12 November 1879, 27.

95 Globe (Toronto), 27 November 1874, p. 2, cols 2-3.

96 Cottrell, "John O'Donohoe and the Politics of Ethnicity in Nineteenth-Century Ontario," 79.

97 Ibid., 80. 
miserably. ${ }^{98}$ Despite the short shrift Shanahan gives to the League, the 1874 elections saw a more positive result for the Catholic League and for Reformers in general as they took power from Macdonald's Conservatives, O'Donohoe's experience notwithstanding. It must be noted that 1874 was the Pacific Scandal election, in which a political scandal erupted over allegations of bribes being accepted by members of the Conservative government for bids on building the transcontinental railway to British Columbia. As a result, Macdonald was forced to resign. The Conservatives lost the 1874 election and the Liberal government of Alexander Mackenzie took power in 1874. A Mackenzie biographer notes that the Pacific Scandal was the key issue in the 1874 elections ${ }^{99}$ so it was perhaps inevitable that the Liberals would win, with or without the support of Irish Catholics.

With a Liberal now in power, however, there was optimism within the Catholic League that Irish Catholics would achieve their fair share of the political spoils. The Irish Canadian observed that the support given by Irish Catholics to Alexander Mackenzie's party was key in its election success and thus Mackenzie was indebted to Irish Catholics "for many of the triumphs which have perched upon his arms." It cautioned Mackenzie not to "forget or treat with old ingratitude" the Catholic community and was reminded of the "fatal blunder committed by the Tories in their treatment of the Catholics." They urged the appointment of an Irish Catholic to the Cabinet sooner rather than later.

When Mackenzie did not accommodate this demand, more and more Irish Catholics came to oppose the Liberal Party, believing that it was as guilty of anti-Irish Catholic discrimination as the Conservatives. ${ }^{100}$ This depressing conclusion was a result of inaction on

98 Shanahan, "The Irish Question in Canada," 30.

99 Ben Forster, "MACKENZIE, ALEXANDER," in Dictionary of Canadian Biography,vol. 12, University of Toronto/Université Laval, 2003-, accessed March 1, 2016, http://www.biographi.ca/en/bio/mackenzie_alexander_12E.html.

${ }^{100}$ LAC, O'Hanly Papers, MG 29, B11, Volume 18, File 10, Home Rule Resolutions, "Grit Treachery Gives Home Rule a Bad Black Eye,” 29 May 1902. 
appointing Irish Catholics to positions of influence, as well as allegations that the Clear Grit faction of the Liberals were abandoning Irish Catholic candidates in favour of Scotch Catholic candidates. One of the first salvos in their abandonment of the reformers came in the wake of the 1875 elections. While still supportive of the Liberals, Patrick Boyle and the Irish Canadian threatened to sever these ties owing to the "narrow bigotry" of the Clear Grits, which was driving Irish Catholics to vote Conservative. Thus Boyle warned that the Catholic League and Irish Catholics in general would closely watch the Grits, and if they persisted in "blind exclusiveness" the League's motto would become "Down with the narrow, contracted bigots." In fact, so certain of this outcome was he that he was making threats to sever the League's connection with the Liberals and "build up a new party in which there may be other tests of eligibility besides being a Scotchman." ${ }^{\prime 101}$

Boyle and Catholic League supporters alleged that the Reformers were actively excluding Irish Catholics from running in elections. Boyle argued that Reformers in Ottawa declared O'Hanly ineligible to stand for nomination "because he is an Irish Catholic." O'Hanly felt the same way, arguing that if the Reform Party is the party of bigotry "then there is no room left for me in that camp." ${ }^{102}$ Likewise, Boyle compared the election results in the county of Lincoln for 1872, 1873-74, and 1874. In the 1872 election, Irish Catholic candidate John McKeown received 555 votes in losing to T.R. Merritt. McKeown did not run in the next two elections, but the reform candidates there each received well over a thousand votes, more than double the votes McKeown had received. The Irish Canadian argued that McKeown's low vote total was a result of Grit supporters refusing to vote for the Irish Catholic. Thus when non-Irish Catholic candidates ran in 1873-74 and 1874, Grit

${ }^{101}$ Irish Canadian (Toronto), 27 January 1875, p. 4, col. 2.

${ }_{102}$ Irish Canadian (Toronto), 16 May 1877, p. 4, cols.1-2. O'Hanly would shift his support to the Conservatives in the 1880s. This is dealt with in Chapter 8. 
supporters returned to the polls and cast their ballot for the Reform candidates. ${ }^{103}$ In the run up to the 1877 elections, the pages of the Irish Canadian were yet again filled with injunctions to vote for Irish Catholic candidates. But this time the grievance related to their apparent betrayal by the Reform Party in the previous election, rather than the Conservatives and Macdonald's prejudice toward Irish Catholics. The "betrayed standard-bearers" included O'Hanly in the riding of Ottawa City, O'Donohoe in East Toronto, McKeown in Lincoln, and Dr Darby Bergin of Cornwall. Boyle urged Canadian Irish Catholics to "give parties and partisans the cold shoulder" and instead stand in a solid body to mobilize for "full recognition of the right of which they have been defrauded - the sacred right of representation." 104 But this message of non-partisan solidarity rang hollow.

By 1877 the Catholic League was more or less defunct owing to inaction on the part of both political parties and consequently Irish Catholics had all but abandoned uniting and pinning their hopes on Liberals or Conservatives. However, Catholic representation continued to be a major issue. There was talk about reviving the Catholic League and even forming Representation Clubs across Ontario and Quebec to agitate for increased Catholic representation in government. ${ }^{105}$ The Irish Canadian continued to discuss the issue of Catholic representation, asserting that if the Irish Catholics of Canada stayed true to their own self-respect and "true to the liberties guaranteed to them by the law of the land" then despite the stifling of prejudice, they would no doubt be successful in their aims. ${ }^{106}$

In June 1877, a meeting was held at St Patrick's Hall in Ottawa to hear O'Donohoe discuss reviving the Catholic League for the upcoming elections. Among the attendees were the familiar members of Ottawa's Irish Catholic community, including O'Hanly, Michael

103 Irish Canadian (Toronto), 17 October 1877, p. 4, col. 4.

104 Ibid.

105 Irish Canadian (Toronto), 13 June 1877, p. 4, cols. 1-2.

106 Irish Canadian (Toronto), 6 June 1877, p. 4, col. 2. 
Starrs, and Ottawa Mayor William H. Waller, among others. O'Hanly, the chairman of the meeting, opened the evening in his usual grandiose way by saying that the very foundation of civilization is organization and it was important that the Irish Catholic minority of Ontario organize themselves into a coherent body. Take a lesson from the Protestants, O'Hanly advised, who were united in Orange, Freemason, Oddfellow, and other lodges. There is strength in union, and until Catholics were organized "they will never get their rights." O'Donohoe then took the stage, and also spoke of the benefit of union and organization. He argued that anything that affected one portion of the Irish Catholic people affected the whole, and thus asked for the assembled to support in reorganizing the Catholic League. To do so, O'Donohoe outlined a plan whereby a meeting would take place in each ward, which would elect as their President "a man of influence", as well as a Vice-President, Secretary, Treasurer, and a committee of three, giving each ward a committee of seven members. This executive committee would form a lay council, which would have control of all election matters. A general council would then be formed by the Presidents of the Lay Councils in the different constituencies to meet on the eve of general elections. On the matter of party allegiance, O'Donohoe noted that prior to the initial formation of the League in 1871 , the Catholics "had not one representative." Seeing that the League was tied to the Liberal Party, the Conservatives soon began courting the Irish Catholic voting block. O'Donohoe was aware of the fact that neither party took up the Catholic cause out of love, but for the practicality of receiving their votes, and this dynamic was suitable as long as Irish Catholics were receiving fair representation. O'Donohoe thus pressed the assembled to unite in a voting block to secure that representation because neither party would act in the interests of Irish Catholics if votes were split.

The next speaker was Ottawa mayor William Henry Waller. Waller was born in 
Tipperary in 1835 and emigrated with his family to Canada in 1853 . He became employed at the Globe newspaper, before moving to Ottawa in $1861 .{ }^{107}$ Waller was a leader in the Irish Catholic community of Ottawa, elected President of the St Patrick's Literary Association of Ottawa in 1871 and a member of the Separate School Board in 1874-5. Waller was also prominent in the wider society. He was elected Alderman in Ottawa's St George's Ward, where he held the position of Chairman of the Finance Committee, and in 1876 Waller was elected Mayor of Ottawa. A Conservative, Waller opposed the formation of the League in 1871, and during this meeting did not shy away from attacking O'Donohoe's attempts to resuscitate it. Waller believed that the League had not achieved anything for Catholics, but had created disunion and brought disgrace upon the community. Waller read a letter from Frank Smith and John O'Connor, who charged that the League had acted in bad faith by proposing to "throw the Catholics of Ontario into the arms of George Brown and sell them like a flock of sheep." Waller further argued that the League did not represent the Catholics of Ontario and ridiculed the idea of committees setting themselves up as representatives of Irish Catholic thought. Waller advised that the League be abandoned and that Irish Catholics should vote at every election for whomever they felt to be the best candidate. ${ }^{108}$ In his rhetoric, Waller's objection to the League rested on his opposition to the formation of an exclusive voting block, rather than party allegiance. Yet Waller also aligned his opposition with O'Connor and Smith, two well-known Conservative opponents of the Liberalsupporting League, and also referenced the League's association with George Brown. And Waller himself was a Conservative. These political references prompted the Irish Canadian to argue that Waller opposed Irish Catholic unity because such an alliance would give the

${ }_{107}$ Geo. MacLean Rose, A Cyclopceedia of Canadian Biography :Being chiefly men of the time : a collection of persons distinguished in professional and political life: leaders in the commerce and industry of Canada, and successful pioneers, (Toronto: Rose Pub. Co., 1886), 39-40.

${ }^{108}$ Irish Canadian (Toronto), 13 June 1877, p. 5, cols. 2-3. 
nomination for Ottawa to someone else. ${ }^{109}$ Still, Waller had support for his position within the Irish community. At a meeting of Irish Catholics in 1878, a resolution stating "no political party should receive the support of the Irish Roman Catholics of this province unless such party is prepared to do them full justice in the matter of representation" was defeated. ${ }^{110}$

The Catholic League's legacy was ambiguous. While it failed to unite the Irish Catholic vote, and was unsuccessful in increasing access to patronage appointments, the Catholic League did achieve a measure of success. For instance, the prospect of Irish Catholics voting en masse against the Conservatives had led Macdonald to appoint Smith and O'Connor to positions of power in the early 1870s. Still, while acknowledging these gains, political battles had to be refought. As late as 1899, for instance, Catholic Liberals were uniting to pressure Prime Minister Wilfrid Laurier to appoint more English-speaking Catholics to the civil service and the judiciary. Mark McGowan has argued that this example of province-wide dissension over patronage underscored Catholic dissatisfaction with their share of the political spoils. ${ }^{111}$ Even still, aside from immediate political gains, the Catholic League's success can be measured in other ways. Michael Cottrell has argued that the key achievement of the Catholic League lay in the fact that O'Donohoe and other leaders in the organization forced the political establishment to recognize Irish Catholics as a distinct sector within the Canadian polity. ${ }^{112}$

109 Irish Canadian (Toronto), 11 July 1877, p. 4, cols. 3-5.

110 Globe (Toronto), 28 August 1878, p. 4, col. 5-7.

111 Mark McGowan, The Waning of the Green: Catholics, The Irish, and Identity in Toronto, 1887-1922, (Montreal and Kingston: McGill-Queen's University Press, 1999), 213.

112 Cottrell, "John O'Donohoe and the Politics of Ethnicity in Nineteenth-Century Ontario," 83. 


\section{$\underline{\text { Conclusions }}$}

This chapter has addressed the place of Irish Catholics in both the legislature and the bureaucracy, and the organization of a voluntary association to push for greater representation. This discussion further shows how the Irish Catholic interest was influenced by and adopted a liberal discourse, achieved influence within Macdonald's inner circles, and stood poised to take Irish constitutional issues mainstream. McNairn sees voluntary associations as schools for democracy, and central, along with the press, in the development of a public sphere for informed debate." ${ }^{113}$ From that perspective, the Catholic League tried to extend the public sphere to include heretofore excluded Irish Catholic voices. Within that field, O'Hanly used the language of liberalism to argue that Irish Catholics deserved to be part of the state bureaucracy and to broaden the inclusiveness of its membership and the fairness of its appointments process. This debate was being waged in the context of a larger debate over the liberalization of the bureaucracy, its severing from old regime patron/client politics and its reimagining as a politically neutral civil service based on education and ability, independently regulated, and measurably efficient. O’Hanly argued that Irish Catholics were systemically excluded because of undue Orange political influence, and that they qualified for appointments under the new reforming standards.

Though the Catholic League challenged the Canadian liberal order by pointing out the exclusion of Irish Catholics from the nineteenth-century liberal state, and despite the discourse of liberalism shown by O'Hanly in his pamphlet on the place of Irish Catholics in the state apparatus, the Catholic League was not advocating for a meritocratic, rational, liberal state. Given the evidence of systemic exclusion and the reluctance of either party to

113 Jeffrey McNairn, The Capacity to Judge: Public Opinion and Deliberative Democracy in Upper Canada, 1791-1854, (Toronto: University of Toronto Press, 2000), 63; Darren Ferry, Uniting in Measures of Common Good: The Construction of Liberal Identities in Central Canada, 1830-1900, (Montreal and Kingston: McGill-Queen's University Press, 2008), 5. 
give Irish Catholics the positions to which their numbers, education, and respectability entitled them, they argued instead for increased representation through the creation of an ethno-religious voting block. Yet, this was not a consequence of tribal attachments: they put their case in liberal terms and took this action to counter what they took to be undue irrational, tribal influence exercised by the Orange lobby with the ruling Conservatives. The rhetoric of the Catholic League expressed a critical view of the place of Irish Catholics in the wider society, a view that was becoming widely held among Irish Catholics of varying political strains. At this juncture Irish Catholic thought-emanating from Liberal, Conservative, nationalist, as well as high-ranking Conservative-leaning clergy-was beginning to reflect a consensus on liberal governmentality that would be demonstrated in the movement for Irish Home Rule, as arguments were made to extend to Ireland the internal self-government that Canada enjoyed under responsible government. Irish Catholics would take Irish constitutional issues mainstream by mobilizing voluntary associations to lobby for Canadian Parliamentary support for Irish Home Rule. 


\section{Chapter Eight: Home Rule and Striving for a Liberal Consensus}

\section{Introduction}

Seeking to counter the negative stereotypical image of their ethno-religious group by performing and displaying sober, middle-class respectability and an ability to govern themselves, promoting and participating in internal settler colonialism, and insisting upon fair and equal representation in the emerging liberal state, in many ways the Irish Catholic associational world, like its Protestant or secular counterparts, contributed to the development of a liberal British Canadian state. In other respects, however, such as clerical resistance to state formation, Fenian sympathies, and calls to create a coherent ethnic voting block, Irish Catholic voluntary associations seemed to compromise the liberal order. The challenge posted by Irish voluntary associations complicate the ways in which Greer and Radforth, McNairn, and Ferry have viewed mainstream voluntary associations in nineteenthcentury Canada. These authors position voluntary organizations as keys arenas within which the state, deliberative democracy, and liberalism developed, and allowed dominant social classes to exercise social control. ${ }^{114}$ However, the associations explored by Greer and Radforth, McNairn, and Ferry were British and Protestant. Disruptions to their analysis arise when we include Irish societies, with their shifting measures of ultramontanism, ethnic attachment, and liberalism.

This chapter will focus on the Irish Home Rule movement as it played out in Canada

114 Alan Greer and Ian Radforth, "Introduction," in Colonial Leviathan: State Formation in Mid-NineteenthCentury Canada, edited by Allan Greer and Ian Radforth, (Toronto: University of Toronto Press, 1992), 6; Jeffrey McNairn, The Capacity to Judge: Public Opinion and Deliberative Democracy in Upper Canada, 1791-1854, (Toronto: University of Toronto Press, 2000), 16; Darren Ferry, Uniting in Measures of Common Good: The Construction of Liberal Identities in Central Canada, 1830-1900, (Montreal and Kingston: McGill-Queen's University Press, 2008), 4. 
in the 1870 s and early 1880 s, culminating with the passing of the Home Rule Resolutions by Parliament in 1882. The resolutions demonstrated that Canadian Irish Catholics had succeeded in making the Irish political question a mainstream issue in Canada and that a liberal consensus was emerging on establishing freehold land tenure and internal selfgovernment in Ireland. Irish Home Rule and land reform were logical within a liberal as well as a nationalist paradigm. Canadian supporters of Home Rule merged Irish self-government with liberal perspectives on Irish land reform. They used the principle of self-government, which was a key plank in the structure of the Canadian liberal order, to advance the argument for Irish Home Rule. They cast their own Irish nationalism in liberal terms and in the process garnered the support of the Canadian liberal order.

Brian Clarke has argued that Home Rule was compatible with being a British subject, and also "fulfilled a Canadian's duty to preserve the empire." 115 Despite the rhetoric of constitutionality and loyalty, however, Peter Toner has argued that the Home Rule movement in Canada was led by Fenians. ${ }^{116}$ Toner is correct to argue that some hardline Irish nationalists and Fenian sympathizers like the Irish Canadian's Patrick Boyle, Felix Callahan, editor of the Montreal Irish journal The Harp, and Jeremiah Gallagher of Quebec ${ }^{117}$, did indeed populate the ranks of Canadian Home Rule branches. In his look at Jeremiah Gallagher, David Wilson references Peter Toner and D.C. Lyne when he argues that "joining

115 Brian Clarke, Piety and Nationalism: Lay Voluntary Associations and the Creation of an Irish-Catholic Community in Toronto, 1850-1895, (Montreal and Kingston: McGill-Queen's University Press, 1993), 231.

116 Peter M. Toner, "The Home Rule League in Canada: Fortune, Fenains, and Failure," The Canadian Journal of Irish Studies Vol. 15, No. 1 (July 1989): 12.

117 David A. Wilson, "The Fenian World of Jeremiah Gallagher," Canadian Journal of Irish Studies, Volume 39, Volume 1 (2015): 31. Wilson argues that Gallagher was a bit of a conundrum. He was both a successful civil engineer who advanced in society and was a physical force nationalist, "but not personally violent." In this sense, Gallagher resembles J.L.P. O'Hanly, also an engineer and, according to Peter Toner, a Fenian. Peter M. Toner, "The Fanatic Heart of the North," in Irish Nationalism in Canada, edited by David A. Wilson, (Montreal and Kingston: McGill-Queen's University Press, 2009), 49. Wilson concludes that Gallagher reminds us that one could be "completely acculturated by the accepted norms, but remain a rebel at heart." I would suggest that the same could be said of O'Hanly, though he did not advocate for physical force. 
the Home Rule movement was part of an explicit Fenian strategy of infiltrating and controlling constitutional nationalists, with a view to shutting them down if they impeded the revolutionary movement." 118 Toner later exaggerates this point when he argues that the revolutionary Fenians blocked a Home Rule branch from being formed in Toronto and infiltrated the Quebec City branch to ensure that it did little to aid the constitutional nationalist cause. ${ }^{119}$ This view does not accord with my research, through which I have found the pages of the heretofore revolutionary Irish Canadian newspaper littered with Home Rule and Land League notices throughout the 1870s and 1880s. As will be shown below, Patrick Boyle himself spoke of the merits and necessity of Home Rule as early as 1872 and continued his support throughout the period under review.

Yet, as Toner also notes, these so-called Fenians were joined in Home Rule branches by moderates like Montreal's Edward Murphy. ${ }^{120}$ Radical nationalists viewed Home Rule as a first step toward independence and Orangemen in the end rejected it because they saw it that way as well. But for a broadening coalition within and beyond the Irish community it represented a compromise solution to an intractable problem. And, as will be demonstrated, owing to the increasing normalization and legitimization of liberalism in Canada, the leading promoters of Home Rule cast the movement in respectable and liberal terms recognizable to the Canadian liberal order.

Irish Catholic voluntary associations were mobilized into action by the Irish Land War and the arrest of Home Rule leader Charles Stewart Parnell in 1881. They pressured the Macdonald government into passing the Home Rule Resolutions, introduced by Irish Catholic M.P. John Costigan in April 1882. In his dissertation, David Shanahan traced the

118 Wilson, "The Fenian World of Jeremiah Gallagher," 28

119 Toner, "The Fanatic Heart of the North," 42.

120 Toner, "The Home Rule League in Canada," 12. 
political machinations behind the 1882 Resolutions and framed their passing as an important event in the history of Irish Catholic politics in Canada and in Canadian discussions surrounding the issue of self-government and political autonomy. ${ }^{121}$ Mark McGowan has also explored discussions surrounding Irish Home Rule in Canada in the 1880s, viewing these debates as helping Canadian Irish Catholics develop their own unique Canadian identity. ${ }^{122}$ Recently, Benjamin Grob-Fitzgibbon has examined the debates in the Canadian House of Commons surrounding Irish Home Rule that occurred in the 1880 s as a way to illuminate the Canadian view of the Irish question and larger Canadian notions of imperialism and Canada's place within the British Empire. ${ }^{123}$

This study approaches the resolutions from a different perspective. Given the important role that myriad Irish Catholic voluntary associations played in supporting Costigan's Resolutions, I frame the resolutions as an extension of grassroots agitation for Irish Home Rule. Moreover, I will analyze the language used by both the voluntary associations and Costigan to illustrate how they cast the issue in terms of extending liberal rule to Ireland. The Costigan resolutions expressed the Canadian Irish Home Rule movement's belief that Ireland ought to be allowed to establish a liberal order in society and politics akin to the Canadian liberal order. In taking this approach, Canadian Irish Catholic Home Rulers legitimized Irish issues in mainstream Canada as they pointed out the inconsistencies in liberalism's universalistic claims. Framing the Costigan Resolutions as expressions of liberalism all but ensured their passage, and thus forced the nineteenth-

${ }^{121}$ David Shanahan, "The Irish Question in Canada: Ireland, the Irish and Canadian Politics: 1880-1922," (PhD diss. Carleton University, 1989), i.

${ }_{122}$ Mark McGowan, The Waning of the Green: Catholics, The Irish, and Identity in Toronto, 1887-1922, (Montreal and Kingston: McGill-Queen's University Press, 1999), 186.

${ }^{123}$ Benjamin Grob-Fitzgibbon, "The Curious Case of the Vanishing Debate over Irish Home Rule: The Dominion of Canada, Irish Home Rule, and Canadian Historiography," American Review of Canadian Studies Vol. 45, No. 1 (2015): 125. 
century liberal state to accept much greater cultural pluralism than it envisioned as this Irish constitutional issue became a mainstream Canadian issue.

\section{Irish Home Rule in the Canadian Liberal Order}

The Canadian model of responsible government served both in Canada and in Ireland as a blueprint for the Irish Home Rule movement. The dissemination of this example by Canadian Home Rulers to the wider society helps to explain why a liberal consensus began to emerge in Canada over Home Rule and land reform. The Irish Home Rule movement originated on 1 September 1870 when Isaac Butt, a pro-imperial, Conservative, Protestant lawyer in Dublin, founded the Home Government Association and began agitating for a kind of federalism, or local rule, for each country in the United Kingdom. ${ }^{124}$ In November 1873, a Home Rule conference was held in Dublin that brought together Home Rule promoters to discuss the philosophy behind the movement and promote its implementation. In a theme that would come to dominate Home Rule rhetoric, Butt looked to Canada as an example of how this would be achieved. In somewhat overblown language, Butt argued that "In 1839 (sic) Canada was with difficulty held by force of arms for the British Crown. Canada was in open rebellion." To placate the rebels, "the experiment was tried of giving Canada Home Rule.” Butt concluded that this experiment had not disintegrated the Empire. Instead, Canada transformed from "the most disaffected and rebellious dependency of Britain" into "the most attached to the English connexion, the most loyal in its allegiance to the British Crown." If this was the result of giving Canada a domestic parliament," Butt concluded, "what reason have we to doubt that similar results would follow it in Ireland? If Canadian

${ }^{124}$ Butt, though a Protestant, led the movement to disestablish the Church of Ireland. Peter M. Toner, "The Home Rule League in Canada: Fortune, Fenians, and Failure," Canadian Journal of Irish Studies 15, no. 1 (1989): 8. As Butt was a member of the Church of Ireland, this indicates that he was a liberal churchman. 
Home Rule is no 'disintegration of the empire,' why is Irish Home Rule? If one has strengthened the integrity of the empire, why should not the other do so too?"125

Commentators in mainstream Canada received Butt and his political program positively. The liberal Globe, for instance, supported Butt's Home Rule approach, and was critical of opponents. A sympathetic and positive article outlining Butt's views on Home Rule was published in October 1871, a summary of an interview Butt gave with the Irish Vindicator, an Irish journal published in London. It was noted that the foremost objective of the Home Rule movement was to secure for Ireland control over its internal affairs through the establishment of an Irish parliament." ${ }^{126}$ Butt concluded that giving Ireland Home Rule under this proposed structure would not mean that Ireland would separate from England, nor that Ireland would withdraw from the authority of the British Crown. Instead, it meant "within the present arrangement of the British Empire under the authority of the British Crown, and by a Government within the principles of the British Constitution the Irish nation should enjoy the right of managing Irish affairs - a right without the concession of which Ireland can never be happy, or contented, or prosperous, or free." ${ }^{127}$

D.C. Lynne has argued that support for Irish Home Rule among the Irish in Canada occurred almost as soon as Butt appeared on the political scene. ${ }^{128}$ Among the Irish in Canada, Home Rule became a popular reform effort whose objectives and principles were expressed in liberal terms. Home Rule was framed as similar to Canada's status within the Empire in order to make it a legitimate and non-threatening political movement to liberal Canadian society. The Irish Canadian, for instance, specifically compared the calls for Irish

${ }^{125}$ Proceedings of the Home Rule Conference Held at The Rotunda, Dublin on The $18^{\text {th }}, 19^{\text {th }}, 20^{\text {th }}$ and $21^{\text {st }}$ November, 1873, (Dublin: The Irish Home Rule League, 1874), 29.

${ }^{126}$ Globe (Toronto), 17 October 1871, p. 3, col. 4.

${ }^{127}$ Ibid.

${ }^{128}$ D.C. Lynne, "Irish-Canadian Financial Contributions to the Home Rule Movement in the 1890s," Studia Hibernica No. 7 (1967): 182. 
self-government to the Canadian model of Dominion government. It argued that Home Rule proposed "an autonomy for Ireland somewhat similar to that enjoyed now by the Province of Ontario; and offers to relegate general legislation and government, as Ontario relegates them to Ottawa, to London." ${ }^{129}$ A March 1872 editorial in the True Witness remarked that the demand for Home Rule was "a just demand, one that the Irish have the right to make and insist upon...no one who claims the same right for Canada can deny."130

Home Rule was therefore presented in a positive light and as a means to strengthen the liberal Empire. Home Rule agitation nonetheless incorporated an inherent critique of British rule in Ireland. Irish nationalist supporters did not hide their disdain for British rule in Ireland. The Harp, a Montreal-based Irish Catholic journal, relentlessly attacked British governance of Ireland and other colonial locales: "the wars in India and Basuto-land - the only countries governed by England for England - are standing proofs of England's inability to govern and are standing claims for Home Rule in Ireland."'131 The radical sentiment that existed within Home Rule was not lost on Canadians. Indeed, as William Smyth has argued, Orangemen would come to portray Home Rule for Ireland as a threat to the future integrity of the Empire. ${ }^{132}$

During a speech at the 1877 St Patrick's Day festivities in Toronto, Patrick Boyle called on the assembled to pledge "anew our fealty to Ireland," by making it known that Irish people, abroad as well at home, "were not contented with the present condition of the Fatherland; nor would they ever be satisfied, either on this or on the other side of the Atlantic, until Ireland enjoyed the blessings which follow native legislation." ${ }^{133}$ Boyle and

129 Irish Canadian (Toronto), 2 February 1876, p. 4, col. 2.

130 True Witness and Catholic Chronicle (Montreal), 1 March 1872, p. 4, col. 2.

131 The Harp, Vol. 6, no. 4 (February 1881), 177.

132 William J. Smyth, Toronto, The Belfast of Canada: The Orange Order and the Shaping of Municipal Culture, (Toronto: University of Toronto Press, 2015), 25.

133 Irish Canadian (Toronto), 21 March 1877, p. 4, col. 6. 
his words were roundly cheered, and he continued by lauding the efforts of the Irish in Ireland who have showed "considerable zeal in their own welfare and in that of their country." 134 Their hearts, Boyle continued, were set on Home Rule "and the man who seeks their suffrage and refuses to endorse that principle, is sure to be defeated by their ballots at the polls." ${ }^{135}$ Boyle recognized the massive political mobilization occurring in Ireland under the banner of Home Rule. By 1876 there were 113 Home Rule clubs in Great Britain, which represented "several hundred thousand voters of the bone and sinew and of also the industry and wealth of those Kingdoms; and therefore constitute a great political power." ${ }^{\text {"136 }}$ The widespread popularity of the movement led Boyle to assert that England would have no peace "till she handed over to the Irish people what rightfully belongs to them." 137

Not content to be mere boosters of Home Rule in Ireland, Canadian Irish Catholics formed their own Home Rule branches. While exact numbers of Home Rule branches in Canada are difficult to obtain, it is likely that a branch existed in most urban centres in Canada. Moreover, through subscription lists that were established to solicit and receive donations for Home Rule, individuals living in a location without a Home Rule association were able to donate to the cause. The lay membership of Home Rule societies followed a similar pattern as the temperance societies, with leadership consisting of more established and prominent members of the professional-, commercial-, and middle-classes. A salient example of this leadership was Montreal's Edward Murphy, the long-time vice-president of the St Patrick's Total Abstinence Society (see chapter 4). Murphy is a prime illustration of an established individual who was active in Irish Catholic voluntary associations, and comfortable functioning both within his own ethno-religious milieu and the wider society.

134 Ibid.

135 Ibid.

136 Irish Canadian (Toronto), 2 August 1876, p. 4, col. 5.

137 Irish Canadian (Toronto), 21 March 1877, p. 4, col. 6. 
Murphy was the first president of the Montreal Home Rule branch, which was established in 1874 as the central Canadian division. The Montreal organization received its charter directly from the main branch of the Home Rule League in Dublin, and was therefore empowered to issue directions for the guidance of other branches that were to be organized in Canada. ${ }^{138}$

In Toronto, a meeting was called for the purpose of forming a branch of the Home Rule Association to co-operate with the existing Montreal branch. The meeting was scheduled to take place in 1874 at the La Salle Hall, which was the home for many events associated with Toronto's Irish community. The president of the organization was John McCormick, an insurance agent with offices in Toronto who for years had been writing polemical letters supporting Home Rule and outlining the injustice of the land situation in Ireland. ${ }^{139}$ Given his professional status, and strong Irish nationalist views, McCormick's election to this office was consistent with the pattern of Irish Catholic voluntary association leadership.

Home Rule organizations in Canada differed from temperance societies with respect to the place of the clergy. While with temperance the clergy played a leading role, in Home Rule organizations their role was more muted as the middle-class laity led the movement. Yet, though the clergy did not control these organizations, clerical support for the movement did exist. At the 1877 St Patrick's Day celebrations, Irish clergyman and temperance advocate Brother Arnold told the crowd that he believed the only panacea for Ireland's ills was the power to make its own laws. He remarked on the time he spent with a visiting Irish politician, O'Connor Power, the M.P. For Mayo. Power informed Brother Arnold that "never were the Irish people, north and south, east and west, so unanimous on any question as they 138 Irish Canadian (Toronto), 14 January 1874, p. 4, col. 2.

139 For some of McCormick's writings, see Chapter Two in this volume. 
are now in demanding Home Rule for Ireland." ${ }^{140}$ Arnold called on the Irish in Canada to "assist our countrymen at home by every legitimate means." 141

The issue of responsible government was twinned with freehold property rights as central to the idea of Ireland as a nineteenth-century liberal state and Home Rule branches advanced just such arguments. The stated purpose of the Montreal branch was to aid their countrymen in Ireland in the reformation of the system of property ownership through the abolition of the landlord system. They advocated for the redistribution of land to the Irish people within an individualist framework, rather than the system of absentee landlordism, which, as they saw it, had been a major source of the troubles in Ireland since the time of Cromwell. At a meeting of the Montreal Branch that occurred in 1874, Edward Murphy pointed out the economic benefits that Ireland would achieve through a reorganization of the land system and self-government. ${ }^{142}$

Toronto's Archbishop Lynch also supported Irish Home Rule and advocated for liberal land reforms. A biographer notes that Lynch supported Home Rule on the grounds that in North America, the Irish had shown themselves to be responsible citizens. ${ }^{143}$ Lynch expressed his support for Irish Home Rule in liberal terms and discussed the need for the Irish to have equal rights. Though it was perhaps ironic to hear the ultramontane Lynch employ the language of rights talk and justice within the liberal social order to promote the cause of Irish Home Rule, it was not out of step within the Irish associational world to see such amalgamations of ultramontanism and liberalism, ${ }^{144}$ such as in the temperance

${ }_{140}$ Irish Canadian (Toronto), 21 March 1877, p. 5, col. 1.

${ }^{141}$ Ibid.

${ }^{142}$ Irish Canadian (Toronto), 22 April 1874, p. 4, col. 5.

${ }^{143}$ Charles W. Humphries, "LYNCH, JOHN JOSEPH," in EN:UNDEF:public_citation_publication, vol. 11, University of Toronto/Université Laval, 2003-, accessed March 10, 2016, http://www.biographi.ca/en/bio/lynch_john_joseph_11E.html.

144 E.A. Heaman, "Rights Talk and the Liberal Order Framework," in Liberalism and Hegemony: Debating the Canadian Liberal Revolution, edited by Jean-François Constant and Michel Ducharme, (Toronto: 
movement which promoted both the power of priests and liberal individualism. ${ }^{145}$ When the branch of the Home Rule Association was proposed for Toronto in 1874, Lynch wrote that he saw no objection to establishing the proposed organization and commended the Irish of the city for initiating such a proposal. Lynch found it "creditable to a man's head and heart that, whilst he cherishes the land of his adoption, he should not forget the land of his birth, or that of his ancestors." ${ }^{146}$ In supporting Home Rule as "the right even of Barbarians," 147 Lynch went further that O'Hanly in the latter's reasoned explanation of the conditions under which he thought the First Peoples were enfranchisable. In a letter printed in the Irish Catholic press in early 1881, Lynch asserted that Ireland was governed by laws that had destroyed its trade and turned the peasantry into slaves toiling to support exorbitant imperial taxation and absentee landlords. This system, which Lynch termed cruel, "caused a shudder of disgust and horror" in every honest heart all over the world. ${ }^{148}$ Lynch went on to compare the condition of the peasantry in Ireland to slaves in the American South, saying that upon a visit to a plantation in Louisiana, he "found the slaves were better fed, better clothed, and better housed" that most of the peasantry in Ireland. ${ }^{149}$ The solution for such a system, Lynch concluded, was to implement Home Rule in Ireland: "the evils which oppress Ireland would be removed by simple justice and equal rights. Let Ireland be governed as is Canada, by her own Parliament; then the laws will be made in the interest of Ireland." 150

Because this incarnation of Irish nationalism was cast in liberal terms it allowed for a broader inclusion of supporters who valued liberal causes. Supporters of Home Rule thus

University of Toronto Press, 2009). For Lynch's credentials as an ultramontane cleric see McGowan, Waning of the Green, 55-56.

${ }^{145}$ See Chapters 3-5 in this volume.

146 Irish Canadian (Toronto), 15 April 1874, p. 4, col. 5.

147 Ibid.

${ }^{148}$ Irish Canadian (Toronto), 6 January 1881, p. 3, cols. 1-4.

${ }^{149}$ Ibid.

${ }^{150}$ Ibid. 
spoke of the movement in terms of a union between "orange and green" rather than as a Catholic-specific initiative. Toronto organizers proclaimed that it was the "sacred duty of Irishmen, of every religious and political bias, to step forward and give countenance and support to the movement now on foot in Toronto." 151 Inclusive rhetoric suggests that Home Rule was more of a liberal than a sectarian issue, and in that respect differed dramatically from the early clergy-led temperance movement, in which the rhetoric was based on Catholic theology. But even Catholic clergy who supported the Irish Home Rule movement issued injunctions for advocating Irish unity couched in liberal terms. For instance, during his 1877 St Patrick's Day remarks on Home Rule, Brother Arnold remarked, "the Orange and Green are blending together; and that unity so dear to every lover of his country is now an accomplished fact." ${ }^{152}$ In this sense the enemy was the gross injustice of landlordism in Ireland, and together Catholic and Protestant Irish both in Ireland and abroad would fight together to amend the situation. The Irish Canadian argued that Irish patriotism always held a union of Irishmen irrespective of creed to be essential to success in the struggle for Irish rights. ${ }^{153}$ During a speech at the 1872 St Patrick's Day celebrations in Toronto, Patrick Boyle asserted that the supporters of Home Rule in Ireland ought to be given credit not just by the Irish at home and abroad, but by "every honest man, no matter what creed or nationality."154 The Home Rule movement, Boyle continued, "involves a principle that should find a willing response in the heart of every freeman."155 Home Rule was framed not solely as an Irish issue, but also as an issue of freedom and self-determination. Boyle argued that the democratic principles espoused within the Home Rule movement were akin to what Daniel

151 Irish Canadian (Toronto), 14 January 1874, p. 4, col. 3.

152 Irish Canadian (Toronto), 21 March 1877, p. 5, col. 1.

153 Irish Canadian (Toronto), 22 December 1880, p. 4, col. 1.

154 Irish Canadian (Toronto), 20 March 1872, p. 5, col. 3.

155 Ibid. 
O'Connell in Ireland, and William Lyon Mackenzie, leader of the 1837 Upper Canadian rebellions, aimed to secure. Home Rule supporters framed the movement as something that would improve not just the welfare of Irish Catholics, but of all Irish people regardless of creed. The rhetoric of inclusiveness and unity, however, would be tested as a new and more militant nationalism emerged in Home Rule circles under the leadership of Charles Parnell.

\section{Parnell, the Land League, and the Radicalization of Irish Home Rule}

Issac Butt died in May 1879 and Charles Stewart Parnell took over the leadership of the movement. Parnell was less enamoured with the British Empire than Butt. Parnell built up relations with the Irish population of North America, including the Irish-American revolutionary group Clan na Gael, and became a leader in the newly established Land League movement. Parnell actively supported the Irish Land War of 1879-1882 in which Irish peasants took up arms against landlords and he was arrested in 1881. Parnell's actions with respect to the Land League were indicative of the more militant politics he brought to the Home Rule movement relative to Butt's conciliatory approach. The Parnellite Home Rule movement tried to be a "big-tent" party embracing both moderate and radical Irish nationalists, as well as parliamentary and extra-parliamentary means. Though he espoused the liberal land reforms of the Home Rule movement, Parnell's militancy created anxiety in liberals who had hitherto supported the movement. Certainly part of the anxiety engendered by Parnell's leadership came from the 1879 "New Departure," an informal understanding between Parnell and American Fenians "which bound them to mutual support and a shared political agenda."156

Not long after Parnell took the reins of the movement, political turmoil in Ireland

\footnotetext{
156 Alvin Jackson, Home Rule: An Irish History, 1800-2000, (Oxford: Oxford University Press, 2003), 37.
} 
intensified. Parnell's militancy was evident as the agricultural situation deteriorated, and his association with the Irish Land League signified his willingness to employ extraparliamentary means to achieve change. The Irish National Land League emerged in the late 1870s to address the issue of land ownership in Ireland, and to ameliorate the destitute and poverty-filled lives of those in rural Ireland. Tenants enjoyed few rights, and many could not pay their rent owing to economic recession in Ireland in the late 1870s. This economic crisis resulted from failures in the potato crop and a cholera epidemic among poultry, which had become a major rural staple in Ireland in the post-Famine era. The first Land League meeting took place in County Mayo in early 1879 , where some 8,000 people were present. ${ }^{157}$ Soon the organization, initially called the Land League of Mayo, became national in scope and changed its name to the Irish National Land League to reflect its growing support among agriculturalists and tenants throughout Ireland. In its initial meeting, held on 24 October 1879 in Dublin, Parnell was elected President of the association. ${ }^{158}$ Irish Home Rule and reformation of the Irish land system were seen as complementary and mutually reinforcing. It was argued that if Ireland were granted Home Rule, the system of absentee landlordism, seen to be the cause of Irish suffering, would be removed. Thus, create an Irish government by Irish people and it would ameliorate the lives of the rural Irish. Indeed, the goal of the Land League was no half-measure of mere rent reductions. Instead, the organization sought the complete abolition of landlordism in Ireland through the workings of an Irish government. ${ }^{159}$

With abolishing the landlord system in Ireland as its objective, the Land League became increasingly successful in resisting the evictions of impoverished Irish tenants. The

157 D.B. Cashman, The Life of Michael Davitt with a History of the Rise and Development of the Irish National Land League, (Boston: Murphy \& McCarthy Publishers, 1881), 163.

158 Ibid, 179-80.

159 Ibid, 180. 
turmoil created by this resistance led to the Irish Land War of 1879-1882, which was an expression of the frustration of Home Rulers and Land Leaguers at what they felt to be inaction on the part of British authorities on land reform in Ireland. Though as its name suggests, the Irish National Land League had branches all over Ireland, the Land War took place largely in the west, centred particularly in Mayo, Galway, Kerry, and Tipperary. The League advocated for tenant rights while engaging in more large-scale protests and social boycotting. ${ }^{160}$ While boycotting might be seen as a form of non-violent protest, Samuel Clark has argued that violence was often used as a way to enforce boycotts. Threatening notices warned people not to deal with certain individuals and attacks were common against labourers, servants, and herdsmen who were expected to withdraw from the employment of any person who had been declared boycotted by the League. ${ }^{161}$ Though the leadership of the Land League took pains to disassociate itself from this violence in an effort to protect itself as a lawful organization, violence was frequently committed by persons who belonged to the League. Indeed, Clark concludes that violence undeniably helped the League in its campaign against landlords. ${ }^{162}$ The escalation of violence, and his own mass appeal, made Parnell a threat to the Empire.

\section{Parnell and the Land League in Canada}

In 1879, Parnell and other members of the executive appealed to "Irishmen the world over,

160 The term boycotting, which was essentially the social ostracism of landlords by the community, was named after a landlord named Captain Boycott. During the Land War, Boycott refused to lower his rents in order to appease the protesters. As a result, local labourers refused to harvest the crops on his land. Seeing this as a way to send a message to the tenant dissidents, the British state drafted approximately 2,000 soldiers to harvest Boycott's crop. And while the soldiers were able to work unimpeded by Land Leaguers, the protest of the local labourers was seen as a victory for tenant rights' advocates as the cost to the British state of this endeavour was roughly $£ 10,000$ while the crop harvested was worth only a few hundred. Samuel Clark, Social Origins of the Irish Land War, (Princeton: Princeton University Press, 2014), 315.

161 Clark, Social Origins of the Irish Land War, 323.

162 Ibid., 324. 
and to those who sympathize with the object in view to aid us in our efforts to obtain for our people the possession of an unfettered soil, and for Ireland the benefits which must result from an unrestricted development of its products and resources." ${ }^{\prime 63}$ Because funds were required to maintain the level of struggle and agitation undertaken by the Land League and Irish tenants during the Land War, the Dublin branch of Land League decided to send Parnell to North America in early 1880 on a fundraising tour. Parnell reasoned that if the tens of millions of Irish in Canada and the United States “could send us $\$ 100,000$ a year for five years, it would not be half a dollar a family in all, and it would go a long way in enabling us to win."164

Though he spent most of this sojourn in the United States, Parnell did visit Canada in March 1880. The mainstream Canadian press offered similarly negative views on Parnell's North American visit as his militancy made them uneasy. On the eve of his arrival, the steadfastly British and Tory Montreal Gazette remarked that regardless of how one felt about the need for land reform in Ireland, Parnell's visit must be viewed as "ill-advised and injudicious." 165 The Globe attacked Parnell's call for Land League supporters to boycott Irish relief funds that he did not operate, and instead only contribute to Parnell's own fund. As an editorial asserted, "The Home Rulers and Land Leaguers could not have sent out a worse champion than the gentleman who now injures their cause on this continent." 166 While the liberal Globe opposed what they viewed as Parnell's crass political manoeuvrings, they nonetheless maintained support for the general objectives of the Land League. The Globe argued that the Land League aims "at reforms which, if wholly effected, would secure Irish

163 Cashman, The Life of Michael Davitt, 170.

164 Ely M. Janis, "The Land League in the United States and Ireland: Nationalism, Gender and Ethnicity in the Gilded Age," (PhD diss., Boston College, 2008), 5.

165 Montreal Gazette, 8 March 1880, p. 2, col. 2.

166 The Globe (Toronto), 6 February 1880, p. 2, cols. 2-4. 
tenants against future famine, and if effected in any degree would ameliorate their condition in proportion." ${ }^{167}$ Indeed, the Globe was more than sympathetic to the Land League cause; they supported it in full measure and believed it beneficial to contribute to the Land League, their views of Parnell notwithstanding. They explained that the design of the League's liberal land reforms was to

secure to the peasants the ownership of their land on terms perfectly just to the landlords. The present owners of the soil would be gradually bought out, and receive the full price for their property. It is only the perpetuity of possession in a particular commodity - land - that would be taken away, and that would be transferred to a class infinitely larger in number. It is impossible to show that justice demands that a small class should be forever maintained in possession of the soil, to the exclusion of a whole nation anxious to pay the full price for it so that they might make it yield an infinitely larger crop. It may be that the particular scheme of the Land League cannot be carried through. But the agitation must result in some benefits to the tenants. It is only by asking all they want that they can get any part of it...The more money placed at the disposal of the leading agitators, who are in general prominent and respectable Irish gentlemen, the sooner will their objects be in some part gained. ${ }^{168}$

Thus, while the Globe supported the broad program of the Land League, they, like the Gazette, were hesitant to support Parnell owing to what they viewed as the militant and divisive approach he took to the Irish question.

Such criticisms notwithstanding, Parnell received a hero's welcome from Montreal's Irish Catholic community, thus signalling a divergence between mainstream Canadian society and the Irish Catholic community with respect to the place of Parnellite nationalism. Parnell and John Dillon arrived in Montreal on the evening of 8 March 1880. A welcoming committee that included President of the St Patrick's Society, F.B. McNamee and Brother Arnold among others, who had taken a train from the city to meet Parnell and Dillon at Vaudreuil, greeted the two. The assemblage arrived at the Bonaventure depot at 9:30 in the evening. When Parnell emerged from the train, he was greeted with thunderous applause, 167 Ibid.

168 Ibid. 
cheers, and hearty welcomes. From there, he embarked upon a sleigh that had been arranged for him, decorated with flags and drawn by four white horses. On the sleigh sat Parnell, Dillon, McNamee, and Brother Arnold. A torchlight procession accompanied the sleigh, and included representatives of various Irish Catholic voluntary associations including St Gabriel's Young Irishmen's Literary and Benefit Society, St Gabriel's Temperance Society, Young Irishmen's Literary and Benefit Society. St Ann's Temperance Society, St Patrick's National Association, the Irish Catholic Benefit Society, the Catholic Young Men's Society, St Patrick's Benevolent Society, St Patrick's Temperance Society, St Patrick's Society, and the Shamrock Lacrosse Club. In the procession, banners with slogans such as "Home Rule for Ireland" were prominent and newspaper reports indicated there were "not less than five or six thousand" torchbearers in the procession. ${ }^{169}$ The next day, the party drove through Montreal's Mount Royal Park and the major streets of the city before heading to an evening reception for Parnell at the Theatre Royal. Tickets to the event cost five dollars per seat and the Globe reported that the audience was composed for the most part of gentlemen, while the ladies present occupied orchestral seats and private boxes. ${ }^{170}$ Seated on the platform were Parnell, NcNamee, Brother Arnold, and Edward Murphy. ${ }^{171}$

In his speech, Parnell compared the land system in Ireland to the Lower Canadian seigneurial system, which he argued was such a detriment to agricultural productivity that it had to be abolished in 1854. Again Canada served as a model for Ireland, and Parnell, like Butt, framed Irish land reform through Home Rule in terms Canadian liberals could understand and appreciate. He spoke of the struggle for land reform in Ireland in decidedly liberal terms, remarking that he sought to abolish an "ancient feudal system" and replaced it

169 The Globe (Toronto), 9 March 1880, p. 1, col. 6.

170 The Globe (Toronto), 10 March 1880, p. 1, col. 8.

171 True Witness and Catholic Chronicle (Montreal), 17 March 1880, p. 2, col. 1. 
with a more just and equal system of land tenure. ${ }^{172}$ Parnell advised the formation of a Land League branch in Montreal that would assist the people of Ireland "in their struggle for a settlement of the land question."173

A Land League branch was soon formed in Montreal under the leadership of Patrick Carroll. The hopes of Ireland, argued the True Witness, were now centred upon the Land League and "Montreal has always been to the front in patriotic works of this nature, and it is hoped its Irish citizens will not let this present effort fall of success for lack of cooperation and assistance." 174 The Montreal correspondent for the Irish Canadian noted that news from Ireland regarding the Land War helped mobilize the Irish Catholic community to join the city's branch of the Irish National Land League in record numbers. ${ }^{175}$ The Montreal correspondent urged the Irish in both Montreal and Toronto to participate in Land League societies, proclaiming that "all interested in the Land movement agree that the stupid and cruel persecution and prosecution policy of the British government will be the means of awakening the interest of Irishmen." ${ }^{176}$ Now is the time, he further declared, "for united action. Let us join hands!" $" 177$ The correspondent from Ottawa urged similar action on the part of the Irish Catholics in that city. He called on them to help "our motherland," and establish a branch of the Land League as Montreal had done. Montreal, he wrote, "has begun the good work; let every city, town, hamlet throughout the Dominion follow her example and start branches of the Land League."

Like Home Rule associations, organizers and members of Canadian-based Land

172 Ibid.

173 True Witness and Catholic Chronicle (Montreal), 31 March 1880, p. 4, col. 2.

174 True Witness and Catholic Chronicle (Montreal), 29 September 1880, p. 4, col. 2.

175 Irish Canadian (Toronto), 10 November 1880, p. 5, col. 4.

176 Ibid.

177 Ibid.

178 Ibid. 
League branches framed the movement as a liberal venture that aimed to strengthen the Empire by attacking landlordism in the name of justice and fairness. As Land League support was expressed in terms of liberal land reform, this once again allowed for the broad inclusion of Catholic and Protestant Irish in the campaign, at least in its rhetoric. This would make the movement appeal to all lovers of liberty, not simply the Irish Catholic community. In a circular printed in the Irish Catholic press, Francis A. Quinn, a lawyer and Land League delegate in Montreal, noted that one main objectives of Land League organizations in Canada was to "educate public opinion throughout the Dominion upon Irish questions." ${ }^{179}$ In doing so, he asserted that they were appealing "not only to Irishmen, but to men of every creed and race." ${ }^{180}$ As an example, he noted that he had spoken on the Irish land question to a meeting of French Catholics in St. Rochs, Quebec and "such was the goodness of my case, that it met with their hearty applause." 181

Deidre Moloney has argued that the organizational structure of the Land League "illustrates the centrality of both Protestants and Catholics to the leadership of the Irish nationalist movement throughout the nineteenth century." "182 The theme of unity was evident in a 15 December 1880 editorial in the Irish Canadian, which argued that the collaborative effort between Protestant and Catholic Irish had historically been a mainstay of Irish patriotism. A "union of Irishmen irrespective of creed," they argued, was essential in order to achieve "the triumph of the cause of Ireland." 183 The editorial went on to detail a mass Land League meeting in Ireland at which both Catholics and Protestants were present, and remarked on such instances being "footprints of history...given at length as the initiation of a

179 Irish Canadian (Toronto), 6 January 1881, p. 5, col. 1.

180 Ibid.

181 Ibid.

182 Deidre Moloney, "Land League Activism in Transnational Perspective," US Catholic Historian 22, no. 3 (Summer 2004): 61.

183 Irish Canadian (Toronto), 22 December 1880, p. 4, col. 1. 
new departure of the Irish people." 184 This would set the stage for Ireland to witness "that blessed augury of her happiness, the union of the Orange and the Green!" ${ }^{185}$ Peter O'Leary ${ }^{186}$, who along with Alderman Peter Ryan, John O'Donohue, and Patrick Boyle, had been elected as chairmen of the Toronto branch of the Irish Land League in 1881, observed that in response to the mass meetings and Land War in Ireland, landlords in Ireland had tried unsuccessfully to set Protestant against Catholic in a strategy of divide and conquer. Indeed, O'Leary continued, though the bulk of the peasantry was Catholic, leaders of the Land League and Home Rule Movements, such as Parnell, were Protestants. O'Leary argued that the enemy was not Protestants writ large. The Land League was not struggling against Protestants, but instead it was the illiberal land system in Ireland that was being fought against. $^{187}$

Local branches further demonstrated the League's rhetoric of inclusivity and liberal values. At its inaugural meeting, the Kingston branch asserted that "any person in sympathy with (the Land League) movement is eligible as a member, irrespective of creed or nationality." 188 At a Land League meeting in Ottawa injunctions to unity between Catholic and Protestant Irish against the unfair land system were heard. One speaker noted that "the Irishmen of Ottawa had the cause at heart, and it was now their duty to share it by coming forward, irrespective of creed, and helping it materially." 189 Speaking at this meeting, John Heney commended his "Protestant fellow country-men for what they had done for Ireland." 190 At a later meeting, Michael Starrs, a leading Irish Catholic businessman in 184 Ibid.

185 Ibid.

186 This is the same Peter O'Leary from the Manitoba colonization scheme, and who wrote Travels and Experiences in Canada, The Red River Territory, and the United States, (London: John B. Day Printer and Publisher, 1877), outlined in Chapter Six of this study.

187 Irish Canadian (Toronto), 17 February 1881, p. 3, cols. 1-2.

188 Irish Canadian (Toronto), 27 January 1881, p. 3, col. 2.

189 Irish Canadian (Toronto), 29 December 1880, p. 8, col. 1-2.

190 Ibid. 
Ottawa, moved that Irishmen were assembled that day not only to respond to "the call from our countrymen at home to contribute to the defence of Parnell and his compatriots," but also to convey to their "fellow countrymen at home our sympathy in their patriotic struggle against landlord tyranny." 191 Starrs further exclaimed that this patriotic struggle "was not one of Roman Catholic versus Protestant, but that of freedom and right against the tyranny and oppression of a heartless landlordism." Likewise, Irish Canadian editor, and vice president of the Toronto branch of the Land League Patrick Boyle, remarked that "every true lover of liberty, no matter what his race or creed, whether he be Protestant or Catholic, orange or green, must look toward that little island where the struggle for emancipation from despotism was now going on and give sympathy in that struggle."192 Boyle went on to say that he was "delighted to see both Protestant and Catholic joining hands in the effort to redress Ireland's wrongs." 193

Women were represented in the movement through the formation in Ireland of the Ladies Land League. This organization was led by Parnell's sisters Fanny and Anna, and emerged as a powerful force after many of the male leaders of the Land League were imprisoned in $1881 .{ }^{194}$ In the United States Ladies Land League branches were widespread as well. Moloney has argued that the Land League's reliance upon female leadership and support was in stark contrast to temperance and other reforms movements among American Catholics, which were by and large a wholly male bastion, with female involvement in Irish Catholic associational and cultural life primarily relegated to church activities, such as charitable bazaars. ${ }^{195}$ Yet female involvement in the Land League was a contested issue.

191 Irish Canadian (Toronto), 3 February 1881, p. 3, cols. 3-4.

192 Irish Canadian (Toronto), 17 February 1881, p. 2, col. 1.

193 Ibid.

194 Moloney, "Land League Activism,: 67.

195 Ibid, 62. 
Moloney asserts that some members of the Catholic hierarchy sought to constrain women's activism on overtly political issues and they received criticism from male Land Leaguers. ${ }^{196}$

Fanny Parnell visited Montreal and the city's Land League feted her with a reception. Dignitaries from Montreal's Irish societies represented the community that evening on the stage with Parnell, including Miss Davis, president of the Montreal branch of the Ladies Land League, M.C. Mullarky, president of St Patrick's National Association, F.B. McNamee, president of the St Patrick's Society, as well as other noted Irishmen of the city including J.J. Curran and C.J. Doherty. In a sign that the wider society was alive to the importance of the Irish Home Rule movement — and the importance of the Irish electorate-Montreal Mayor Jean-Louis Beaudry also attended the event. The evening consisted of speeches by Curran, Beaudry, Doherty, and a representative of the Toronto Land League. During her speech, Parnell acknowledged that Land Leagues in Canada suffer the disadvantage of being under British dominion, but also noted that Irishmen in Canada "seemed very free, or perhaps they would be in the gaol for their utterances, as they would be in England." 197 Fanny Parnell was a forceful speaker when she spoke of landlordism in Ireland. She argued that England was not Ireland's worst enemy; rather, she asserted that Ireland's worst enemies were found in its police, constables, and spies who were "ready to do the bidding of a magistrate and shoot down the people." 198 The evening concluded with Parnell advocating for increased numbers and energy for Land Leagues in Canada and across the globe.

Despite their role as political agitators, members of the Ladies Land League could not escape the gendered context in which they operated. Newspaper reports gendered Parnell with attributes typically associated with femininity and weakness. It was remarked, for

\footnotetext{
196 Ibid.

197 The Globe (Toronto), 5 July 1881, p. 7, col. 5.

198 Ibid.
} 
instance, that she appeared more like a "high school miss about to read a valedictory" than someone about to give a lecture. ${ }^{199}$ Moreover, as remains standard in descriptions of women in public, mention was made of her appearance and clothing as it was noted that she was "dressed in white, without ornaments." ${ }^{200}$ There had been no such comments on her brother's appearance the previous year.

The major aim of the Land League branches, as noted by Francis Quinn, was to "send assistance to our countrymen in Ireland."201 This was done through the establishment of subscription lists, the proceeds of which were sent to the main Land League organization in Dublin. ${ }^{202}$ A Land League fund was established by the Irish Canadian and its editor Patrick Boyle. The fund aimed to raise money for the activities of the Land League through subscriptions and transmit the funds to Ireland to be applied to the Land War. In a 24 November 1880 editorial, the editors of the Irish Canadian (it was not Boyle, who at this point was grieving the loss of his 18-year-old son) argued that the Land War was a just cause as it was fighting "against a land system which has blighted that country like a curse."203 Despite his bereavement period, the editors noted that Boyle was not "holding back from the cause of his race and country," and "has set on foot by his subscription of last week to the Parnell defence fund a movement which we trust to see followed out by every man of our race in Ontario." 204

As in the temperance movement, clergy and middle class were united in the Land League effort at this point as donations to the Irish Canadian Land League Defence Fund came from voluntary associations and Catholic clergy across Ontario. By the following

\footnotetext{
199 Ibid.

${ }^{200}$ Ibid.

${ }^{201}$ Irish Canadian (Toronto), 6 January 1881, p. 5, col. 1.

${ }^{202}$ Lynne, "Irish-Canadian Financial Contributions," 184.

${ }^{203}$ Irish Canadian (Toronto), 24 November 1880, p. 4, col. 1.

${ }^{204}$ Ibid.
} 
week, several individuals had contributed generous amounts to the fund. ${ }^{205}$ Boyle had set up the Irish Canadian Land League Defence Fund in late 1880, and editions of the Irish Canadian thereafter came with emotional appeals to Irishmen to donate to the cause. In the 15 December 1880 edition, special attention was paid to the activities of John O'Reilly, an Irish Catholic merchant living in Almonte, close to Ottawa. Irish Catholics reading that edition of the paper were advised to "follow the example of that earnest and practical patriot, Mr. John O' Reilly...not content with subscribing his own money generously,” the article asserted, O' Reilly also "made a canvass of his neighbours and multiplied thus his own devotion by calling out the devotion of 18 others. ${ }^{, 206} \mathrm{O}^{\prime}$ Reilly's seriousness in this endeavour was lauded, and the Irish Canadian went on to query "what Irishman of earnestness equal to his, will undertake to discharge the duty in the same way at London, Guelph, Hamilton, etc." ${ }^{207}$ A few weeks later, an Irishman from Eganville, also close to Ottawa, submitted a letter along with his donation, noting that "as Irishmen we cannot be indifferent to such an appeal."${ }^{.208}$

A Land League fund was also established in Montreal, and operated in conjunction with the True Witness. Here too donations came in rapidly and from across the spectrum of the Irish Catholic cultural world. Voluntary associations such as Montreal's Young Irishmen's Literary and Benefit Society voted a sum of $\$ 200$ to the Land League Fund in November 1880. ${ }^{209}$ Irish Catholic clergy were also represented as donors. One subscriber, and letterwriter, "An Ontario Priest," donated ten dollars to the fund. He wrote that he was happy to see the establishment of the fund, and he was glad that the paper was "proving true to the

${ }^{205}$ Irish Canadian (Toronto), 1 December 1880, p. 4, cols. 3-4.

${ }^{206}$ Irish Canadian (Toronto), 15 December 1880, p. 4, cols. 3-4.

207 Ibid.

${ }^{208}$ Irish Canadian (Toronto), 29 December 1880, p. 8, col. 1.

${ }^{209}$ True Witness and Catholic Chronicle (Montreal) 24 November 1880, p. 4, col. 2. 
cause for which (it) was established." ${ }^{210}$ He further hoped that "many of the cloth will go an do likewise. The laity, I am confident, will be to the fore. By a united effort we can effect wonders and our cause is a holy one."211 "Another Ontario Priest," who also donated ten dollars to the fund, noting that he was happy to follow the lead of "An Ontario Priest" and hoped "others may follow his patriotic example," took up his call for action just the following week. ${ }^{212}$

As with Home Rule associations, support for the Land League was accompanied by a degree of radical anti-English sentiment. The True Witness, for instance, believed that "the appeal made by Mr. Parnell for the formation of branches of the Land League will come with more force to the Irish people on this side of the Atlantic when they remember that it was the land laws of Ireland and the artificial famines which they produced which forced them from their homes... a change in the land laws is absolutely necessary if Ireland is not to suffer from periodical famines and ultimately become depopulated." 213 Such radical rhetoric had the potential to alienate Irish Protestants from the cause, as it expressed Home Rule in nationalist, rather than liberal terms. Parnell's arrest by British authorities further put the cause in doubt.

\section{$\underline{\text { Parnell's Arrest and the Defence of Legal Liberalism }}$}

In 1881, the British government passed two pieces of legislation that led to the arrest of Parnell. The first was a Land Act meant to moderately reform the land system. It sought to reduce rents and gradually phase out landlordism, as well as make it easier for tenants to purchase land. However, the legislation was seen as an ineffective half-measure by Land

210 True Witness and Catholic Chronicle (Montreal), 25 February 1880, p. 4, col. 4.

211 Ibid.

212 True Witness and Catholic Chronicle (Montreal), 3 March 1880, p. 4, col. 6.

213 True Witness and Catholic Chronicle (Montreal), 31 March 1880, p. 4, col. 3. 
Leaguers. In October 1881, Parnell attacked the Land Act as a toothless piece of legislation that did not deal with the root of the problem in Ireland. Already seen as a potentially dangerous agitator by the British government for his role in the increasingly violent Land War, these pointed comments put him in an even more precarious position. Parnell's arrest was made possible by another major piece of legislation the British government passed in 1881, the Coercion Bill. The Coercion Bill was passed by Gladstone's Liberals in the hopes of quelling the turmoil in Ireland caused by Land League activities. The 1881 legislation outlawed the Land League and allowed for the arrest of individuals without trial, including Parnell and many other Land League supporters.

While in prison, Parnell and other arrested Land League leaders continued to attack the 1881 Land Act, issuing the No Rent Manifesto. This polemical tract called on small tenant farmers in Ireland to engage in a campaign of passive resistance against landlords by withholding rents: "The executive of the National Land League...feels bound to advise the tenant farmers of Ireland from this day forth to pay no rents under any circumstances to their landlords until Government relinquishes the existing system of terrorism and restores the constitutional rights of the people." 214 To this call was added the assertion that the Irish in North America would contribute to the cause: "Our exiled brothers in America may be relied upon to contribute, if necessary, as many millions of money as they have contributed thousands to starve out landlordism and bring English tyranny to its knees."215

Both the Gazette and the Globe applauded the decision to imprison the Irish leader. They maintained that Parnell was guilty of arousing hostility toward the Land Act, and was therefore deserving of arrest. This is consistent with the mainstream press's reaction to the

${ }^{214}$ New York Times, 21 October 1881, (online), http://query.nytimes.com/mem/archive-free/pdf? res=9C04E6DF113CEE3ABC4951DFB667838A699FDE, last accessed 27 February 2016.

${ }^{215}$ Ibid. 
increasing powerful place of the radical HBS planning St Patrick's Day events, discussed in Chapter Four. In that case, demonstrations of Irish Catholic ethno-religious identity were acceptable until they began to overtly and aggressively challenge British and Orange dominance in Canada. Likewise, Home Rule was acceptable to Canadian liberals until the movement radicalized under Parnell's leadership. Parnell's challenge to the British Empire through his support for the Land War and his combative nationalism, his liberalism notwithstanding, was too much for the wider Canadian society and they responded by denouncing him and his leadership of the Home Rule movement.

The Gazette had supported the land reform measure legislated by the British Government in 1881, and argued that the arrest of Parnell would come as no surprise to those who had been following the events in Ireland. They wondered, moreover, why Parnell had not been arrested earlier, and were baffled "that the leniency of the Government has been so long exercised toward one who so boldly and openly has incited the people of Ireland against the greatest measure of reform passed this century." ${ }^{216}$ They charged that Parnell's "endeavor to deprive the people of the advantages which the Land Act is calculated to confer upon them," his "violent condemnation of the measure before it had even undergone a practical test," and his desire to make that test of such a character that it could not fail to be "unsatisfactory to large numbers of tenants, and wrongly prejudice them against the Act," meant his arrest should inspire no sympathy among even his supporters. ${ }^{217}$ In similar language, the Globe asserted that no person who had followed the course of events in Ireland could doubt that Parnell's arrest was "not only justifiable, but necessary." ${ }^{218}$ The reaction of mainstream press outlets such as the Globe and Gazette indicates that the wider

216 Montreal Gazette, 14 October 1881, p. 4, col. 1.

217 Ibid.

218 Ibid. 
society was beginning to view Home Rule as it functioned under Parnell as a dangerous menace.

The potential for arrests without trial recalled the Canadian suspension of habeas corpus in the 1860 s amidst the Fenian threat and from a liberal position the Irish assailed British violations of individual rights and the due process of law as tyrannical and despotic. The Irish Canadian's Land League Defence Fund ceased operation in January of 1881, "so as to save it from seizure in the Dublin Post Office by a government exercising the power of an absolutism." 219 At a Land League meeting in Toronto, it was stated that "when the Habeas Corpus Act was suspended it took away all right of citizenship and what Ireland needed was not that, but a bill of justice." ${ }^{220}$ Peter O'Leary, a member of the Toronto Land League, believed the Coercion Bill and the arrest of Parnell would not stop the agitation or feelings which brought the agitation into existence. On the contrary, O'Leary continued, it would intensify such feelings. Governing Ireland as a conquered country in the interests of landlords, he continued, would no longer do, for the people as a whole were "dead against it." 221

Irish Catholic organizations and individuals voiced their outrage at the Parnell arrest as an affront to liberal values. At a meeting of Montreal Irishmen protesting the arrest, which included speeches by C.J. Doherty, Francis A. Quinn, and J.J. Curran; it was resolved that "the conduct of the British government in imprisoning" Parnell "meets with our unqualified condemnation that no words are strong enough to express our indignation at this despotic proceeding." ${ }^{222}$ Similar sentiments were expressed by the Ottawa branch of the Land League,

219 Irish Canadian (Toronto), 20 January 1881, p. 4, col. 6.

${ }^{220}$ Irish Canadian (Toronto), 17 February 1881, p. 2, col. 3.

221 Irish Canadian (Toronto), 17 February 1881, p. 3, cols. 1-2.

${ }^{222}$ Irish Canadian (Toronto), 27 October 1881, p. 1, col. 7. 
where that organization expressed its indignation at the arrest of Parnell. ${ }^{223}$ The Windsor Land League branch also condemned the arrest of Parnell as "an action worthy only of the despotic and cruel government of England."224 The Land League branch in Quebec City expressed "feelings of indignation at the conduct of the British government" for "attempting to suppress that legal and constitutional body, the Irish National Land League."225

Individual Irishmen in Canada also spoke out. In Ottawa, Michael Starrs believed that it was the duty of every Irishman in Canada to repudiate the British government's arrest of the leaders of the Land League movement. ${ }^{226}$ John Heney believed that the arrests were a betrayal of legal liberalism as through those actions the British government showed itself to be tyrannical. He argued that the Land League had always kept within its bounds and committed no illegal act. Heney further commented that the British government may terrorize the people and subdue them with bayonets, but those actions would be no credit to the British Empire. Heney concluded by stating he did not think there existed another country "under the sun where the people are so badly treated as those in Ireland.",227

Irish Catholic politicians also weighed in on the Parnell arrest. In the Canadian House of Commons, Timothy Warren Anglin defended the Land League against accusations of violence and terror. Anglin argued that since the Land League had been suppressed in the early 1880 s, the number of violent acts in Ireland had actually increased. Though he produced no data to substantiate this claim, Anglin nonetheless attributed the increase in violence to the British government's suppression of the Land League, an association he saw as organized openly and fairly for the purposes of constitutional agitation. The curtailment of

223 Irish Canadian (Toronto), 27 October 1881, p. 8, col. 3.

${ }^{224}$ Irish Canadian (Toronto), 10 November 1881, p. 5, col. 2.

225 Irish Canadian (Toronto), 27 October 1881, p. 5, col. 3.

226 Irish Canadian (Toronto), 27 October 1881, p. 4, col. 5.

227 Ibid. 
the Land League left agriculturalists in Ireland with no peaceful, constitutional mode of agitation and forced them to resort to "what has been called the wild justice of revenge."228 For Anglin, then, the restrictions on the legal, open, and legitimate Land League organization led to increased violence in Ireland, rather than that violence being a result of the actions of the League.

As the Irish prisoners continued to be detained, questions about their arrest and treatment were raised by the London (Ontario) based Liberal paper, Catholic Record. An editorial criticized the conduct of the British government for its treatment of Irish Home Rule leaders, saying their actions were "deserving of a most severe condemnation." 229 They first questioned the legitimacy of arresting these "honorable gentlemen who enjoyed the confidence and esteem of their fellow-countrymen. ${ }^{230}$ In language reminiscent of Patrick Boyle's recriminations toward the Canadian state's suspension of habeas corpus in the aftermath of the Fenian Raids in the 1860s, the Catholic Record asserted that a principle of English law is that every man charged with a crime is considered innocent until he has been proven guilty. ${ }^{231}$ The Record believed that this betrayal of legal liberalism led to poor and unjust treatment of men who were as yet innocent under law: "that these prisoners are subject to a treatment worse than cruel in the manner of food and lodging, the whole action of the government is an outrage on humanity." ${ }^{232}$

There were calls to aid their fellow-countrymen in Ireland in any way possible against the illiberal actions of the British government. The Ottawa Land League branch sent a message to Home Rulers in Ireland, that "in this contest with tyrannical rulers, they can

${ }^{228}$ Official Debates of the House of Commons of the Dominion of Canada: Fourth Session, Fourth Parliament, edited by John Chas. Boyce, (Ottawa: MacLean, Roger \& Company, 1882), 1060-1061.

229 Catholic Record (London), 13 January 1882, p. 4, col. 1.

${ }^{230}$ Ibid.

${ }^{231}$ Ibid.

${ }^{232}$ Ibid. 
count on their fellow-countrymen here as well as elsewhere; and we pledge ourselves to give every moral and material aid in our power to assist them in their struggles."233 Land

Leaguers in Montreal pledged to assist their countrymen by every means within their power to secure for the Irish people the land, the law-making, and the government of Ireland. A 19 October 1881 editorial in the clerical True Witness spoke of the necessity of action and further monetary assistance:

The Irishmen on the side of the Atlantic have now a solemn duty to perform. Patrick's Day parade speeches and sunbursty [sic] orations by patriotic politicians are excellent things in their way, but they do no good to Ireland...the Land League should be sustained and supported now more than ever. Monetary assistance should be given and given at once and freely by those who can afford it. Nothing can be done without money. The Irishmen in the States are coming forward nobly; though living in Canada we are none the less Irish than they; nor is our duty less plain. ${ }^{234}$

As in the $1860 \mathrm{~s}$, the mainstream Canadian press supported the suspension of habeas corpus as a temporary expedient in order to deal with the threat of radical Irish nationalism. The Globe observed that "Arbitrary imprisonment, under suspension of habeas corpus, is, without doubt, about the last peaceful resource of civilization for stamping out incipient rebellion," and concluded that Prime Minister Gladstone and the British government, would not have made use of it (the suspension of habeas corpus) but in a case of extreme necessity. That such a case had arisen admits of no reasonable doubt...The Land League had long since driven law and order out of certain districts in Ireland and was fighting with might and main against all efforts to restore them. What resource was left but to place its chief agitator where he must perforce be harmless for a time, and have opportunity to reflect calmly upon the course he has been pursuing. ${ }^{235}$

Though they were apologetic for the betrayal of legal liberalism, the Globe nonetheless applauded the suspension of habeas corpus as a "peaceful" and transitory measure to aid in

${ }^{233}$ Irish Canadian (Toronto), 27 October 1881, p. 8, col. 3.

234 True Witness and Catholic Chronicle (Montreal), 19 October 1881, p. 4, col. 4.

235 Globe (Toronto), 17 October 1881, p. 4, cols. 1-2. 
the greater good of protecting the law and order that Parnell and the Land League threatened.

The arrest of Parnell led Home Rule and Land League supporters in North America to convene a meeting of Irish National Land League organizations in Chicago in November and December $1881 .^{236}$ Close to two thousand delegates attended the meeting, including judges, army officers, clergymen, lawyers, doctors, and merchants. Two Canadians, F.H. Maguire and J.A. Kilroy, were on the executive committee of the convention. There were also numerous Canadian delegates who attended the event, including John Daly Purcell of Montreal. A successful barrister, Purcell would go on to become a judge of the circuit court of the district of Montreal. Like many other Irish Catholic elites who were successful in the wider society, Purcell was also active within the Irish community. In addition to his membership in the Irish National League, he was a member of the St Patrick's Society, the Shamrock Lacrosse Club, and the Emerald Snowshoe Club, of which he was president from 1884 to $1890 .{ }^{237}$ In an interview regarding the 1881 Irish National League's Chicago convention, Purcell remarked that the effect of the convention would be to consolidate the union between Irishmen in North America. He observed that an important series of resolutions were passed, which conveyed to the people of Ireland the sympathy and support of the Irish in North America, as well as assurances that they could count on the support of "their kindred here" in their struggle for their rights. Another important function of the Chicago convention was to raise money to send to Ireland in continuance of the Land War. ${ }^{238}$ The sum of a quarter million dollars was promised, and $\$ 28,000$ was given right there at the convention. Land League organizations in Canada contributed significantly to this sum in

\footnotetext{
236 The Harp (Montreal), Vol. 7, no. 3 (January 1882), 128.

237 Rev. William Cochrane The Canadian Album. Men of Canada; or Success by Example in Religion, Patriotism, Business, Law, Medicine, Education and Agriculture, Vol. 5. (Bradley, Garreston \& Co.: Brantford, Ontario, 1895), 121.

238 True Witness and Catholic Chronicle (Montreal), 14 December 1881, p. 3, col. 4.
} 
the wake of Chicago. The Montreal Land League sent a sum of $\$ 1,000$ toward the Chicago convention, while the Quebec branch reported that they had already forwarded $\$ 400$ on account of their subscriptions to the sum called for at Chicago, which ranged from twentyfive cents upward. ${ }^{239}$

The Irish Canadian praised these actions, but was critical of the lack of enthusiasm shown in Toronto for the Land League. It remarked upon the promise made at the Chicago convention to raise the sum of $\$ 250,000$ to be applied in aid of the Irish National Land League, and asked what Toronto had done in similar respects. "Toronto," it said, "has done nothing. Where is our local branch of the Land League? What is it doing? If not dead, it should rouse itself from the culpable apathy which has fallen upon it and do something worthy of the cause which it is supposed to represent." 240

It would only take a few short months before the Toronto Irish society, along with Irish societies across the country, would do something deemed worthy of Irish Home Rule. Steps were taken by the Irish community to have one of their representatives, John Costigan, introduce resolutions in the House of Commons condemning British misrule in Ireland, calling for Ireland to become a self-governing entity, and advocating for the release of Parnell and the other imprisoned Land League members. In so doing, Canada's Irish Catholic leadership were able to mobilize voluntary associations throughout the country to pressure the Macdonald government into passing the Home Rule resolutions, and securing formal acknowledgement by the Canadian state that the issue at the heart of Irish nationalism was the liberalism of the British Empire.

${ }^{239}$ Irish Canadian (Toronto), 9 February 1882, p. 4, col. 3.

240 Ibid. 


\section{Organizing the Home Rule Resolutions}

In the wake of Parnell's arrest, and owing to continued unrest in Ireland, a plan was devised by a number of prominent Irishmen in Ottawa for John Costigan, a member of parliament from New Brunswick and a leading Irish Catholic voice, to introduce a motion in the House of Commons which would express the House's support for Irish Home Rule and call for Parnell's release from prison. The first step in bringing the Costigan resolutions to Parliament involved reaching out for support from Irish Catholic organizations to show the popularity that Costigan's resolutions had among the Irish in Canada.

Because the Home Rule movement and Land League organizations had such broad appeal among the Irish in Canada, a united Irish voting block organized around the issue of Home Rule was a genuine possibility. This fact was not lost on J.L.P. O'Hanly as he searched for the names and addresses of all Irish societies in Canada, as well as the names of priests looking for distinctly Irish names, or names "that even smelt Gaelic," so he could communicate directly with the Irish electorate and initiate the plan to "thoroughly frighten" Prime Minister Macdonald into action. ${ }^{241}$ He realized that a general election was close at hand, and during election campaigns, "'Pat', instead of being openly despised and spat upon, (was) courted and caressed, lifted high upon a political ladder." 242 O'Hanly reasoned that the Irish Catholic vote was desired at election time, and if Irish Catholic voters were unanimously in favour of passing resolutions supporting Irish Home Rule then election time would be the most likely period in which such resolutions would pass in the House of

${ }^{241}$ LAC, O'Hanly Papers, MG 29 B11 Volume 18 "Status of Irish Catholics," undated; File 10 "Home Rule Resolutions," undated. J.K Foran, a noted Irish Canadian lawyer and author also remarked that the 1882 resolutions were widely supported by Irish associations. The Riel and Home Rule Questions: Hon. John Costigan's Speech at Woodstock, N.B., Mr. Costigan's Letter to Lord Lorne on Home Rule for Ireland, Gladstone's Bill Foreshadowed, Opinions of the Irish National Newspapers (Messrs. Curran, Coughlin, \& C., 1887), 15-16.

${ }^{242}$ LAC, O'Hanly Papers, MG 29 B11 Volume 18 "Status of Irish Catholics," undated; File 10 "Home Rule Resolutions," undated 
Commons. As he remarked, "I learned at O'Connell's knee that England's difficulty was Ireland's opportunity and by a little stretch of imagination I tried to apply it to the situation." 243

Once he finished compiling the list of associations, O'Hanly met with Costigan, Michael Starrs, and Martin O'Gara, a leading Irish Catholic lawyer in Ottawa, to discuss Home Rule and the content of the proposed resolutions. The group devised a plan that would first see a series of resolutions forwarded to Starrs, president of Ottawa's St. Patrick's Literary Association. Starrs was to introduce these proposals at the society's regular meeting, and a copy of the proceedings was to be sent to the Irish organizations recorded on the list complied by O'Hanly. Each society was instructed to introduce and vote on similar motions at their meetings. The second step in the process was to have Costigan introduce those resolutions in the legislature.

The initial proposals read at the meeting of the SPLA in Ottawa employed the language of liberalism and loyalty to frame the content of the message. They asserted that the Irishmen of Ottawa and the surrounding country deeply sympathized with the people of Ireland in their struggle for justice and self-government, and resolved that John Costigan be requested to move a resolution in the House of Commons in support of the movement for Irish Home Rule. In articulating these views, the Ottawa organization stressed the benefits that Irish Home Rule would have for the wider Empire, emphasized their own history as loyal Canadians, and pointed out the positive result that the liberal system of home rule has had in Canada. It was moved:

That the Irish people of Canada, under the influence of self-government and just laws, have always acted loyally and true to their adopted country and it is now the duty of the representatives of the people of Canada in Parliament assembled to present an

${ }^{243}$ LAC, O'Hanly Papers, MG 29 B11, File 10 "Home Rule Resolutions," undated. 
address to Her Most Gracious Majesty expressive of sympathy with their fellow subjects in Ireland and praying that Her Majesty might be pleased to release forthwith the political prisoners in Ireland and grant to that country a local Parliament and an improved system of land laws.

That the union of the British colonies with the Mother Country being chiefly based on their love of British citizenship it is the duty to uphold the honor of their citizenship and to remonstrate against all acts of injustice or of cruelty practiced upon the person of any of their fellow citizens in any part of Her Majesty's dominions.

That it is the duty of the British colonies to represent to Her Most Gracious Majesty that the domestic affairs of Her Empire should be regulated so as not to bring dishonor upon the citizenship of her subjects or to give rise to those angry feelings and disaffections in the British Isles which in the past have placed the British colonies in such unfavourable contrast with the United States of America. ${ }^{244}$

The second paragraph is rooted in the Lockean social contract, whereby men have the duty to remonstrate against violations by the state. Locke argued that in return for the government's preservation of property, individuals relinquished to the government certain rights and autonomy. ${ }^{245}$ If the government broke this contract by acting against the rights of individuals those individuals had a duty to point out and oppose those actions. By framing these resolutions in such liberal Lockean terms, this motion stressed the place of the Irish as liberals in what they viewed as an illiberal Empire.

The SPLA of Ottawa would be the first of many Irish Catholic voluntary associations to endorse the proposed resolutions. The proceedings of the Ottawa meeting were published in the local press and sent "over the Dominion to every village, town, and city" where an Irish society was known to exist. ${ }^{246} \mathrm{O}$ 'Hanly wrote that "right loyally one and all responded to this patriotic call to arms." ${ }^{247}$ Support for the Costigan plan came from diverse Irish Catholic associations, including Land League Branches, temperance organizations, and

${ }^{244}$ Irish Canadian (Toronto), 2 March 1882, p. 5, col. 1.

245 Jerry Bannister, "Canada as Counter-Revolution: The Loyalist Order Framework in Canadian History, 1750-1840," in Liberalism and Hegemony: Debating the Canadian Liberal Revolution, edited by JeanFrancois Constant and Michel Ducharme, (Toronto: University of Toronto Press, 2009), 120.

${ }^{246}$ LAC, O'Hanly Papers, MG 29 B11 Volume 18 File 10 "Home Rule Resolutions," undated.

${ }^{247}$ Ibid. 
benefit societies, and thus demonstrated the wide breadth of support Home Rule had had amongst the Irish in Canada.

These supporters aimed to transform Irish society into a liberal order on par with the Canadian model. The Father Mathew Temperance Association of Almonte passed a resolution expressing their belief that people in Ireland were entitled to the same system of local government and liberal land laws which had worked so beneficially in Canada, and that they sympathized with their fellow-countrymen in Ireland in their struggle for freedom and justice. ${ }^{248}$ They further remarked that they felt it to be in the interest of the Empire that Home Rule be granted to Ireland and that the political prisoners be immediately released. In light of these motions, the Father Mathew Association of Almonte requested Costigan to move a resolution to that effect and that Mr. D.G. Macdonnell, the M.P. For North Lanark-the federal riding where the organization was located - be requested to support the Costigan address.

At their meeting of 27 March 1882, the Charitable Irish Society of Halifax placed their full support behind the Costigan resolutions, noting that as a body they believed Home Rule for Ireland to be the only effective means of "the harmony and good will which should exist in all parts of the United Kingdom.." 249 The association believed that Ireland should have the same system of land ownership and land laws "which have worked so beneficially in Canada. ${ }^{250}$ And as with the Almonte temperance society, the Halifax C.I.S. urged the Member of Parliament for the City and County of Halifax to support Costigan in any resolution he may offer to obtain justice to Ireland."251

Parliamentary members were aware of the increased political influence of the Irish

248 Irish Canadian (Toronto), 23 March 1882, p. 8, col. 4.

249 Catholic Record (London), 7 April 1882, p. 4, col. 1.

250 Ibid.

251 Ibid. 
Catholic community in Canada as a whole, but in case some needed reminding it was necessary to emphasize their political power. An Irish Canadian editorial remarking on the perceived opposition warned those who may try to block the resolutions to "beware," and called on Irishmen in Canada to "rise as one man to strike them at the polls." 252 Thus, when it was rumoured that Samuel Tilley of New Brunswick was cool to the resolutions, the editorial asserted that Tilley's "re-election in Saint John can be made impossible by our fellowcountrymen. ${ }^{" 253}$ While the Irish Canadian predictably was more open and aggressive about the underlying challenge to the Macdonald government, Costigan and the Catholic voluntary associations of all stripes who were recruited to express their support couched it in terms of liberal principles that would prove unexceptionable to citizens by alluding to the rights Canadians enjoyed.

The proposed Home Rule resolutions were much discussed during the $1882 \mathrm{St}$ Patrick's Day festivities. In Charlottetown a meeting was held by several Irish societies on that day for the purpose of expressing support for the proposed resolutions. ${ }^{254}$ In Toronto, John O'Donohoe spoke to an assembled crowd in support of the proposed Costigan action. He urged British Prime Minister Gladstone to give the Irish people a "transcript of the constitution and laws of Canada, where her Majesty's Irish subjects are happy, prosperous and contented people. ${ }^{, 255}$ He then read a resolution calling for Irish self-government that was to be forwarded to Costigan to be moved in the House of Commons. Such a resolution, O'Donohoe continued, "would be highly conducive and in the best interests of the Empire at large," and would be a step toward granting rights to the people of Ireland as are now

${ }^{252}$ Irish Canadian (Toronto), 13 April 1882, p. 4, col. 5.

${ }^{253}$ Ibid.

254 Senate Debates, $4^{\text {th }}$ Parliament, $4^{\text {th }}$ Session, Vol. 1, 518, http://parl.canadiana.ca/view/oop.debates_SOC040404

255 Irish Canadian (Toronto), 23 March 1882, p. 5, col. $\overline{2}$. 
enjoyed by the people of Canada." ${ }^{256}$ At the 1882 St Patrick's Day festivities in Oshawa, held under the auspices of The Emerald Beneficial Association, similar injunctions to support Home Rule and the proposed Costigan motions were expressed. There, it was moved that because the system of Home Rule granted to Canada by an Act of the British Parliament in 1841, and extended under the BNA Act of 1867 has worked to increase the prosperity and happiness of Canada as a component of the British Empire, and because Irish emigrants and their descendants, under the just and impartial laws made by Canadians themselves, have carved out substantial homes for their families, either as pioneers or in towns and cities, they concluded that it would be "in the interests of the Empire that Home Rule should be granted to Ireland and the political prisoners incarcerated under the Coercion Act should be immediately released." 257

Michael Starrs spoke at the 1882 St. Patrick's Day festivities in Ottawa and noted that the Irish in Canada supported Home Rule because while "Irishmen here in our adopted land are alright and compare favourably...with those of any other nationality" it was as unreasonable "to expect a man of moderate means getting three meals a day, to be happy and contented whilst his brother, his own flesh and blood, is digging in a drain or begging from door to door as to expect Irishmen in their adopted land to be happy and contented whilst their kith and kin in the Old Land are starving in the midst of plentiness." 258 With this support expressed, the stage was set for Costigan to introduce the resolutions in Parliament.

\section{$\underline{\text { Costigan Introduces the Resolutions }}$}

When Costigan introduced the resolutions in favour of Irish Home Rule in the House of

${ }^{256}$ Ibid.

${ }^{257}$ Irish Canadian (Toronto), 23 March 1882, p. 5, cols. 2-3.

258 Ibid., p. 5, cols. 3-4. 
Commons in April 1882 he cast the document in thoroughly liberal terms. Speaking of the importance of the Home Rule question, and the seriousness with which he had thought about the difficult subject, Costigan said his actions stemmed from a "desire to discharge my duty faithfully towards my fellow-countrymen, and also towards the people of Canada."259 Costigan expressed the values of liberalism when he said that Canadian Parliament was the best venue to present the topic of Home Rule because it was a place "where the liberties and rights of the people are so safe and so well secured" and because he believed Canadians "have rights and liberties not enjoyed by the people in Ireland." Costigan asserted that because Canadians feel and enjoy the blessings "of a wise Government, and a wise system of government" they "will readily extend their sympathies to those less fortunate in that respect." He believed that there was a feeling in the House, and among the people of this country, that Ireland stood alone among countries where hardship had existed where harsh treatment has been used towards its people, and "it will be hard to convince me that in the opinion of any public man Ireland alone should remain misgoverned and have no hope for a better state of things."

Fearing that attacking the rule of any particular party "might create a hostile feeling," Costigan quickly noted that it was not his place to "attack the policy of different Governments that have ruled Ireland in times past" nor to "show to what an extent the misgovernment of that country has been carried." In fact he stated that without fear of contradiction he need not make any accusation against any Government in order to establish the point that Ireland has been misgoverned, but needed "only quote the opinions of leading Ministers themselves to prove that it has been admitted by all parties that Ireland has not

${ }^{259}$ Costigan's speech in Parliament on 20 April was published in Official Debates of the House of Commons of the Dominion of Canada: Fourth Session, Fourth Parliament, edited by John Chas. Boyce, (Ottawa: MacLean, Roger \& Company, 1882), 1030-1033. 
been wisely and well governed." Costigan argued that a great change had come over the public mind regarding the issue of reform in Ireland, "and that the time is not far distant when men will not say it is too soon to grant this reform, but the wonder will be that it had not been granted many years ago."

Because Costigan was aware that Parnell's arrest was endorsed by many in Canada, even among some long-time supporters of Irish Home Rule, he attempted to silence critics who viewed the resolutions as a defence of the treasonous and revolutionary Parnell. Costigan maintained that he and "the great body of the Irish people condemn any indefensible acts perpetrated in Ireland as strongly as any people in the world condemn them" yet also affirmed that such agitation occurred in Ireland because no other means were available to them to affect the kinds of change they desired. It was his solemn conviction that if the Land League leaders who at that time were imprisoned in Ireland were still at liberty to use constitutional means to advocate the cause they had at heart there "would be more order among the people than there is to-day." He believed that "the outrages of which the telegraphic wires tell us from day to day" were exaggerated in many cases, but the fact that there were not more cases of violence in Ireland was attributable to the fact that "the men who are imprisoned, from the time they first headed this movement to the time they were imprisoned, confined themselves to constitutional means of agitation." Noting a difference of opinion on the question of whether Parnell and his associates utilized means that were unconstitutional, he maintained that those who felt Parnell and the Land League did engage in extra-parliamentary means were criticizing "men who are striving and struggling to bring about reform, men who are seeking the redress of grievances that have been endured century after century." He stated that it was only fair to say that the Government themselves were responsible for a great deal that had taken place in Ireland. 
Costigan's introduction, then, utilized language suggesting the culpability of the English government in mismanaging Ireland. Costigan would go ever further when he maintained that "Irishmen have suffered more than any other portion of the Empire." But, aware that veering toward an anti-English Fenianesque rhetoric could do his cause harm, Costigan transitioned toward language of liberal justice and Irish loyalty toward, and a feeling of belonging within, the Empire. He argued that the Irish have not been second to anyone in defence of the country and in building up the power of the Empire. Because of this loyalty and service, Costigan continued, he did not think what Irishmen were asking was unreasonable, unconstitutional, or inconsistent with the rights, liberties and freedom of other members of the Empire. Granting these measures to Ireland would bring the country closer to the Empire: "the more you relax the bonds which now fetter Ireland the more strongly you bind her to England." To provide an example, Costigan discussed Canada's Dominion status. He asked if the concessions made to the Canadian provinces by the Imperial Government weakened the tie between them and England. No, he answered. In fact

nothing has tended more to strengthen that feeling of loyalty and attachment to the Mother Country now prevailing than the fact that she was willing to extend to this country those liberties which every free man has a right to expect. The same result would follow concessions to Ireland. You can make Ireland faithful. Irishmen have been as faithful as Englishmen in every great battle and in every great undertaking for adding glory and lustre to the British flag. If you deal with Irishmen as with other intelligent beings - if you admit that they are created by the same God, and are entitled to the same rights as other men, and give them a measure of self-government - give them the rights that every man has a right, to expect, you will find them, like Canadians, loyal and true, ready and willing to support that Empire which would shelter and not crush them.

Costigan's speech was framed in the language of liberalism, loyalty, and respectability. Costigan asserted that Irishmen had not only contended for their constitutional rights, but had shed their blood to build up the foundations of the Empire. He pointed to 
Canada as a successful example of a liberal Home Rule governmental model, and went on to say that the more the bonds around Ireland were relaxed the stronger would the ties be that connected Ireland with England. Should this be the case, according to Costigan, then among the Irishmen who had already shed their blood abundantly in defence of the imperial possessions would be found the most true and loyal subjects of the Empire.

\section{The Liberal Language of the Resolutions}

The resolutions likewise invoked the language of liberalism and loyalty to the Empire and Canada. ${ }^{260}$ They made plain that the Irish subjects in the Dominion were among the "most loyal, most prosperous, and most contented of your Majesty's subjects," and that they presented these resolutions to ameliorate the positions of the Irish in the interests of "this loyal Dominion and of the entire Empire." ${ }^{261}$ The resolutions contended that because the Irish in Canada had prospered under a federal system allowing each province considerable powers of self-government, such a system ought to be established in Ireland so that the Irish in Ireland would feel 'the same pride in the greatness of your majesty's Empire...and the same devotion to and veneration for our common flag as are now felt by all classes of Your Majesty's loyal subjects in this Dominion."262 While the resolutions did call for clemency to be extended "to those persons who are now imprisoned in Ireland charged with political offences only, and the inestimable blessing of personal liberty restored to them" they were careful not to refer to Parnell or his associates by name. These resolutions were clearly written in order demonstrate the loyalty of the Irish, not only to Canada but to the wider

\section{Empire.}

${ }^{260}$ For the full resolutions please see Appendix B.

${ }^{261}$ LAC, John Costigan Fonds MG 27 I D5, 000444-000445; House of Commons Debates, Fourth Parliament, Fourth Session, Vol. 1, 1033-34.

${ }^{262}$ Ibid. 
Given this wording, it would have been difficult for the Protestant majority to attack these resolutions. Indeed, in its description of the passing of the Home Rule resolutions the Globe noted that Costigan's speech was "moderate in tone." ${ }^{263}$ Even opponents of land reform in Ireland agreed with the Globe regarding the restraint of the resolutions. While the Toronto-based organ of the Orange Order in Canada, the Sentinel and Orange and Protestant Advocate, predictably called the resolutions "a ridiculous political farce," they nonetheless viewed the resolutions as being as "mild and non-committal as possible."264 The moderation and loyalty of the resolutions resulted from political pragmatism. The resolutions moved in the House differed from the original ones drafted by O'Hanly, which were more incendiary in tone and content. The major difference between the originals and the ones that actually passed was the deletion of the call for an immediate release of the imprisoned Parnell. Prime Minister Macdonald had persuaded Costigan to accept the changes or face not having Parliament's support for the resolutions. ${ }^{265}$ Upon learning of the compromises demanded by Macdonald, Costigan went to visit O'Hanly and the two went over the counter-proposals of the government. O'Hanly reasoned that the specifics of the resolution mattered less than the fact of their acceptance. He remarked that "people would know that the Parliament of Canada passed resolutions in favour of Home Rule for Ireland," and this would "instil new hope and new vigour for those fighting for Irish Home Rule." They decided that the alternative to accepting them was the government rejecting the originals, and therefore O'Hanly advised their acceptance "in the interests of Home Rule."266

${ }^{263}$ Ibid.

264 The Sentinel and Orange and Protestant Advocate, 27 April 1882; Andrew Thomson, "The Sentinel and Orange and Protestant Advocate, 1877-1896: An Orange View of Canada," (M.A. Thesis Wilfrid Laurier University), http://scholars.wlu.ca/etd/10;

${ }^{265}$ Shanahan, "The Irish Question," 66; LAC, MG 26 A John A. Macdonald Fonds, Vol. 206, 87629, Macdonald to Lorne, 2 May 1882.

${ }^{266}$ LAC, O'Hanly Papers, MG 29 B11 Volume 18 File 10 "Home Rule Resolutions," undated. 
From his perspective, Macdonald knew that if he did not allow a version of the Home Rule resolutions to be passed, it would enrage the considerable and increasingly powerful Irish Catholic electorate who were unified in their support for Home Rule. At the same time, however, he felt that including the call for Parnell's release in the resolutions would have gone too far in its criticism of the Imperial Government. ${ }^{267}$ The resolutions as they were conveyed in Parliament, then, illustrate the way in which the political context of Canada shaped the expression of Irish nationalism in Canada and the negotiation between moderate and radical Irish nationalism therein, as well as their growing power in the liberal state.

This sentiment of political pragmatism was greeted with mixed reactions among the Irish in Canada. London's Catholic Record supported the resolutions, at the same time as they acknowledged the adulterated tone and changes to the wording of the motions. While the editors remarked that in their own opinion, they would "have preferred to see the sympathy of Canada for Ireland more clearly and forcibly expressed than it is in these resolutions," but weakened as they were, no doubt to "meet the prejudices of some few members of the House," they were nonetheless happy to see that the resolutions contained "an explicit declaration of Canadian support for home government in Ireland." 268 The True Witness also lamented the changes to the resolutions, and noted that they hoped the modifications made to Costigan's resolutions would not sacrifice their principles. ${ }^{269}$ However, the Irish Canadian pragmatically argued that had the language in the Home Rule Resolutions been more provocative they would not even have been introduced, let alone passed, in Parliament. ${ }^{270}$

It was Edward Blake who was left to articulate the liberal critique of the British

267 Shanahan, "The Irish Question," 66.

268 The Catholic Record (London), 28 April 1882, p. 4, col. 4.

269 True Witness and Catholic Chronicle (Montreal), 29 March 1882, p.4, col. 3.

270 Irish Canadian (Toronto), 27 April 1882, p. 4, cols 2-3. 
government over the violation of constitutional rights. An elite Anglican of Irish descent who was educated at Upper Canada College, Blake was an attorney, former premier of Ontario, and at the time Costigan introduced his resolutions, the leader of the Liberal Party of Canada. In 1892, Blake became a member of the British House of Commons as an MP for South Longford, where he represented the Irish Parliamentary Party. He was a keen observer and participant in both Canadian and Irish politics, and his views carried much weight. While Blake supported Costigan's resolutions, he did so with much reluctance as he considered the language of the resolution to be weak and unsatisfactory. During his speech in the debate following the introduction of the resolutions, Blake outlined in some detail what he viewed as the misrule of Ireland by England, and his belief in the necessity of both land reform and Home Rule. Blake remarked that he listened to Costigan's resolutions with some regret because he found them "emasculated."271 Blake asserted that the resolution "was much weaker than the resolution he (Costigan) put on the paper in the first instance."272 One area to which Blake took particular offence was the clause that spoke of granting the clemency of the Crown to the arrested Land Leaguers in Ireland. Blake argued that those men were deprived of the constitutional right of trial by jury and were imprisoned under a law "which does not call on the Government to charge them with any crime whatever."273 What ought to have been demanded, argued Blake, was the restoration of the habeas corpus and a trial by their peers. It was not an application of clemency or mercy that should be asked for, "but a hope that the ordinary constitutional rights of every British subject may be extended to these particular subjects." 274

271 Speeches Delivered by Hon. Edward Blake, the leader of the Liberal Party and a Synopsis of the Debate on the Home Rule Resolutions in the House of Commons, (Toronto: C. Blackett Robinson, 1886), 17, https://archive.org/details/speechesdelivere00blak.

272 Ibid.

${ }^{273}$ Ibid.

${ }^{274}$ Ibid. 
Blake's arguments for due process were reminiscent of the Irish Canadian's defense of legal liberalism in the wake of the Fenian Raids of 1866, and though he found the resolutions weak, unsatisfactory, failing, and poorly framed, he nevertheless wanted them to succeed and he advocated for their success. Blake wanted the Canadian people, through their representatives in Parliament, to express to the Imperial Government respectfully, but firmly and plainly, that as four million British subjects they believed that the integrity of the Empire demanded self-government for Ireland. Blake thus voted "with reluctance" for the motion, because it was "infinitely better that it should pass than that it should be rejected because some may think it too weak and others too strong." 275

Blake and others wanted the resolutions to go further than Costigan's rewording allowed for. Politically speaking, however, this would have been impossible. Boyle and the Irish Canadian agreed with much of what Blake had to say, but were nonetheless critical of the speech. It was unfortunate, they argued, that "Blake thought proper to belittle where he himself could have done no better." ${ }^{276}$ They asserted the belief that if there were room for stronger, bolder, expression of the case of Ireland before Parliament, if there was even "the ghost of a chance" that stronger, bolder, more comprehensive views on the issue of Home Rule would have been accepted by the representatives of the people of Canada, then to criticize Blake's "great speech" would have been unwise. ${ }^{277}$ As it stood, however, such a speech would not have been within the realm of the politically possible, thus leading the Irish Canadian to conclude that Blake "went out of his way on a bootless errand when he attacked the strength and the spirit of Mr. Costigan's Resolutions."278

\footnotetext{
275 Ibid.

276 Irish Canadian (Toronto), 4 May 1882, p. 4, col. 4.

277 Ibid.

278 Ibid.
} 
Political Compromise and The Place of Irish Catholics in the Liberal State

Given that the resolutions were passed in the Canadian Parliament, the representative institution of the Canadian people, they were seen as the voice of an entire country. Yet, it is difficult to determine the impact Costigan's Resolutions had on the Home Rule movement itself. In Ireland, they were seen as an important symbolic gesture of support from the Irish population of Canada. Parnell himself gave thanks to the Irish in Canada for putting forward the resolutions. ${ }^{279}$ Moreover, a lengthy report in the Dublin-based Freeman's Journal in May of 1882 laid out the process by which the resolutions were passed by the Canadian Senate and House of Commons. ${ }^{280}$ Laudatory in its analysis of the impact of the resolutions, the Freeman's Journal remarked that,

As an historical event, we believe this message from Canada to the Mother Country is without parallel. The fact of one free Parliament praying another for the restoration of a third, which has been flagitiously suppressed, is a striking and singular as well as an impressive spectacle...the renewed thanks of the Irish people at home and abroad must be proffered to the generous colonists who have thrown themselves so manfully into the breach in their behalf. ${ }^{281}$

Yet Ireland did not achieve Home Rule as a result of the Costigan resolutions. Instead, the importance of the resolutions lay in what they demonstrated about the Irish Catholic community in Canada, and the crucial place of voluntary associations therein.

Inspired by the Home Rule and Land League organizations in Ireland, galvanized into action by the Land War and Parnell's visit to North America and his subsequent arrest, Irish Catholics in Canada organized their own Home Rule and Land League branches, held their own meetings, raised their own money, and agitated their own government into action. The

279 The Riel and Home Rule Questions, 25-6.

280 Irish Canadian (Toronto), 25 May 1882, p. 8, col. 4.

281 Ibid. 
Costigan resolutions forced the issue of Irish independence into the discourse of the liberal order in Canadian society and politics by expressing the desire that Ireland be allowed to liberalize its social and political structure. While the mainstream press regarded the militant Parnell with suspicion, on the whole they supported the liberal objective of Irish Home Rule. The question that Englishmen and Irishmen must resolve, a Globe editorial maintained, "is how to give Ireland the government of her own affairs without detracting from the dignity of the Imperial Parliament" ${ }^{\prime 282}$ Thus, for the Globe, the question did not revolve around whether Ireland should have self-government, but how to best establish an internal governing structure within an imperial paradigm.

In May of 1882, it was announced that John Costigan would become the Minister of Inland Revenue in Macdonald's cabinet. ${ }^{283}$ Shortly after Costigan's appointment, it was announced that Frank Smith would also be appointed a minister and John O'Donohoe would be named a Senator. There was criticism that political favours were being bandied about, and that Costigan agreed to Macdonald's demand to alter the language of the original resolution in return for political rewards. O'Donohoe argued that he had cast off "old party affiliation to join Smith and Costigan and support the National Party, which was advocating a national tariff and fair play to every section of the community." ${ }^{284}$ Yet, he had been quick to point out that their support was qualified: if the government of Macdonald "did not carry out its pledges, our support should forthwith be withdrawn: should the ministry of which we are supporters slight or neglect our Irish Protestant or Irish Catholic countrymen, or prove untrue

${ }^{282}$ Globe (Toronto), 23 June 1882, p. 4, col 3.

${ }^{283}$ Coincidentally, this was also around the time when Parnell was released from prison after signing the Kilmainham Treaty, an agreement with the British government that saw Parnell withdraw the No-Rent Manifesto and denounce agrarian crime in return for his, and other Land Leaguers, release from prison and the British government's promise to address those with rent arrears and leaseholders, two constituencies excluded from the benefits of the 1881 Land Act. Jackson, Home Rule, 45.

${ }^{284}$ True Witness and Catholic Chronicle (Montreal), 14 June 1882, p.3, cols 3-4. 
to the principles of the National Policy, we shall at once withdraw our support." 285

The trio's inclusion into government was greeted as the successful culmination of the advancement of Catholic rights. Unlike Smith's and John O'Connor's placement in government during the heyday of the Catholic League in 1871, the placement of Smith, Costigan, and O'Donohoe in 1882 was more widely supported by the Irish community. Many offered private responses to the addition of the three to Macdonald's government and were hopeful about the good work they could accomplish for their ethno-religious group. ${ }^{286}$ The Irish Canadian viewed the appointment of Costigan "as an upward movement in the recognition of Catholic rights." ${ }^{287}$ They felt that "the interests of our race and its future in our adopted country will be safe in the hands of Smith, Costigan, and O'Donohoe." ${ }^{288}$ While they wished that this "installment of justice" had come sooner, so that "our people not so long to tarry in dependence on the good offices of 'strangers'", they were overjoyed that it occurred and the "powers that be have risen to the height of their necessities and practically applied the remedy." 289 A letter writer from Ottawa remarked upon the "general satisfaction" felt by all Irishmen in the city owing to Costigan's new cabinet position, and believed that he would be "an honor to the Irishmen of Canada." 290

J.L.P. O'Hanly also supported the move to the Conservatives. O'Hanly wrote a letter to the Irish Canadian in which he rhetorically questioned how long a lifelong Liberal such as himself could support a Conservative government, as Costigan, Smith, and O'Donohoe were asking many Irish Catholics to do. O'Hanly noted that he hesitated to choose political parties because so far as Irishmen were concerned very little difference existed between the Liberals

${ }^{285}$ Ibid.

${ }^{286}$ LAC, John Costigan Fonds, MG 27 I D5, 000105, 000111.

${ }^{287}$ Irish Canadian (Toronto), 1 June 1882, p. 4, col. 2

${ }^{288}$ Irish Canadian (Toronto), 8 June 1882, p. 4, col. 2.

${ }^{289}$ Irish Canadian (Toronto), 1 June 1882, p. 4, col. 2

${ }^{290}$ Irish Canadian (Toronto), 1 June 1882, p. 5, col. 3. 
and the Conservatives. He argued that he placed political considerations aside to support the party he felt would act in the best interests of Irish Catholics. While for years he felt that to be the Reform Party, he was quick to assert that should they not act this way when in power he would have no hesitation to abandon them. When he first heard of the addition of the three Irishmen to cabinet, O'Hanly said his astonishment was “only equalled by joy, being an instalment of justice far beyond expectations." ${ }^{291}$ From this point, he contended, he "could no longer hesitate which side to take." 292 "For years under trying circumstances," he argued, Irish Catholics had been agitating for fair representation, and now that that goal has been achieved it should be taken advantage of and support given to the three representatives in cabinet. ${ }^{293}$ Irish Catholics who refused to support the Conservatives would be, in the words of O'Hanly, "egregious blockheads." ${ }^{294}$ He dismissed claims that Costigan, Smith, and O'Donohoe were selling the Irish vote, saying that if John O'Donohoe was trafficking "for selfish purposes, for personal aggrandizement, in the votes of his countrymen, then all I can say is that he is very much changed since I first knew him. ${ }^{, 295}$ As an honest Liberal, O'Hanly concluded, he found justification in supporting the Conservative Government and believed that this course of action would also be supported "by the overwhelming voice of our country-men." 296

While this shifting back and forth between the two major political parties can be seen as self-serving, such moves were logical for Irish Catholics whose loyalty lay more with their ethno-religious community than with any one political party. As O'Hanly's letter to the Irish Canadian illustrated, many Irish Catholics viewed the two parties as equally

${ }^{291}$ Irish Canadian (Toronto), 15 June 1882, p. 5, col. 1.

${ }^{292}$ Ibid.

${ }^{293}$ Ibid.

${ }^{294}$ Ibid.

${ }^{295}$ Ibid.

${ }^{296}$ Ibid. 
disagreeable with respect to their views on Irish Catholics. Throughout the middle part of the nineteenth century, the Liberal Party was dominated by George Brown, whose No Popery Campaign was anathema to the Irish Catholic community, while the Conservatives, with Macdonald at the helm and given his role in the suspension of habeas corpus in 1866 and longtime links to the Orange Order, was equally objectionable. The political shifts between Liberal and Conservative taken by Irish Catholics at this juncture were not based on ideological differences. Rather, they were based on which party was seen to have the potential to better serve the collective Irish Catholic population.

Costigan would continue to be a spokesperson for the Irish Catholic population, for whom the significance of his position lay in the fact that he could press for Irish Catholic interests. In October of 1884 Costigan visited Trenton where he was waited upon by prominent Irish Catholics in order to congratulate him on his government position. In glowing terms, The True Witness remarked that those who waited to do honor to Costigan "comprised members of both political parties." 297 That both Liberals and Conservatives took part in the affair bore "testimony to the estimation in which the representative Irish Catholic in the cabinet (is) held by his fellow countrymen and co-religionists." 298 Costigan responded that he was gratified to see the names of "staunch Reformers" among the attendees, and he assured the gathered crowd "that there was never a time in his past record, nor did he believe a time would come in the future when he would sacrifice his principles as an Irish Catholic to party purposes." 299

O'Hanly and others framed the placement of Costigan, Smith, and O'Donohoe in the

297 True Witness and Catholic Chronicle (Montreal), 22 October 1884, p. 1, col. 5.

298 Ibid. The use of the word "countrymen" in this context is confusing. Costigan was born in New Brunswick, so presumably the county in question could be Canada, though in the spirit of the occasion it likely referred to Ireland.

299 Ibid. 
government as the culmination of years of struggle by Irish Catholics in Canada to achieve their place in Canadian society and the liberal order. In rhetoric that echoed the language of the Catholic League, the Irish Canadian argued that until Canadian politics was free from religious discrimination, it was the duty of Catholics to vote only for other Catholics. ${ }^{300}$ Until religious discrimination ended, Catholics would "suffer if they do not unite squarely on the Catholic candidate, be his politics what they may." 301 They maintained "the blind partizan will tell us that there should be no such religious distinctions in political affairs...until the blind partizan can show satisfactorily that in this province religion is no bar to political preferment, that scaly individual should be kept at arm's length." 302

\section{$\underline{\text { Conclusions }}$}

Irish internal self-government within the United Kingdom and the Empire, and the issue of land reform, were logical within a liberal, as well as a nationalist, paradigm. These were issues for which Canada could serve as a model and with which liberal Canadians might find sympathy. By the 1880 s, liberalism had reached such a dominant place in Canadian society that it became unacceptable to liberal Canada for an avowedly liberal Empire to deny Ireland the self-government and property rights that it gave its colonies. Yet, the replacement of the pro-imperial Isaac Butt with the more militant Charles Stewart Parnell, and the radicalization of the land issue that led to the Land War, compromised the support for Irish Home Rule among liberals. The British state responded to the violence and rebellion of the Land War action by passing the Coercion Act, which revoked civil liberties, much as had been done in Canada with the suspension of habeas corpus during the Fenian Raids. While Irish Catholics

${ }^{300}$ Irish Canadian (Toronto), 1 June 1882, p. 4, cols. 3-4.

301 Ibid.

302 Ibid. 
deployed liberal rhetoric to denounce the British government as tyrannical and despotic, the mainstream Canadian press accepted such betrayals of legal liberalism in response to Parnell's threat to established order.

Despite this, Irish Catholic leaders mobilized voluntary associations across Canada to pressure the Macdonald government into passing the Home Rule resolutions, by which the Canadian state acknowledged that the Irish nationalist question had, at this juncture at least, resolved itself into a question of extending to Ireland practices of liberal governance enjoyed in Canada. From an Irish Catholic perspective, the resolutions, even in their moderated tone, were claimed to have given them the presence in the governmental inner circle for which they had contended through the Catholic League in the 1870s. This was achieved by strategically using the prospect of the upcoming election and by targeting an issue that this time made an Irish Catholic voting block seem a very real possibility. Catholic voluntary associations of all stripes were recruited to express their support and did so in terms of extending liberal government to Ireland. 


\section{Chapter Nine: Conclusions}

This thesis has attempted to write Irish Catholics and Irish Catholic voluntary associations into the Canadian liberal order, and not solely as the irrational, tribal, ultramontane brake on modernity that a stereotyped retelling might suggest. In exploring three specific Irish Catholic voluntary associations in nineteenth-century Canada that were formed at particular times to confront particular social and political issues, this study probed the ways in which those organizations engaged with a Canadian state and society that Ian McKay argues was experiencing a liberal revolution. ${ }^{1}$

Pinning down an agreed-upon definition of liberalism has been notoriously difficult. McKay sees the concept of the individual as informing liberal theory, particularly in relation to property rights. ${ }^{2}$ E.A. Heaman builds upon this to argue that political liberties held by individuals were the cardinal principles of liberalism. ${ }^{3}$ By contrast, Bruce Curtis sees the nineteenth-century liberal concept of the individual as being underpinned by the notion of community. ${ }^{4}$ Darren Ferry also sees community in which all occupations, class interests, religious affiliations, and political parties are included, as key to Canadian liberalism. In addition, Ferry argues that a liberal community is one that is dedicated to the promotion of honest industry. ${ }^{5}$ Because Ferry focuses on a liberal communitarianism that crossed religious

1 Ian McKay, "The Liberal Order Framework: A Prospectus for a Reconnaissance of Canadian History," Canadian Historical Review 81, no. 4 (2000), 621.

2 Ian McKay, "Canada as a Long Liberal Revolution: On Writing the History of Actually Existing Canadian Liberalisms, 1840s-1940s." In Liberalism and Hegemony: Debating the Canadian Liberal Revolution, edited by Jean-François Constant and Michel Ducharme, (Toronto: University of Toronto Press, 2009 ), 350.

3 E.A. Heaman, "Rights Talk and the Liberal Order Framework," in Liberalism and Hegemony: Debating the Canadian Liberal Revolution, edited by Jean-François Constant and Michel Ducharme, (Toronto: University of Toronto Press, 2009), 143.

4 Bruce Curtis, “After 'Canada': Liberalisms, Social Theory, and Historical Analysis," in Liberalism and Hegemony: Debating the Canadian Liberal Revolution edited by Jean-Francois Constant and Michel Ducharme, (Toronto: University of Toronto Press, 2009), 183.

5 Darren Ferry, Uniting in Measures of Common Good: The Construction of Liberal Identities in Central Canada, 1830-1900, (Montreal and Kingston: McGill-Queen's University Press, 2008), 16-17. 
and class boundaries, he branded associations that broke apart due to sectarian or class factionalism as having problematic "non-liberal attitudes," such as the expression of collectivist identities based on religion and ethnicity. E.A. Heaman likewise argues that the Catholic Church demonstrated illiberalism through its emphasis on the collective rights of the Catholic Church. ${ }^{7}$ These scholars, then, have virtually ignored nineteenth-century Irish Catholics in studies of liberalism and liberal voluntary associations. This is unfortunate because research suggests that the Irish Catholic associations and individuals in this study were in fact part of the liberal order, although their ethno-religious position certainly mediated and shaped how they interpreted and practiced liberalism. Seeking to bring ethnicity and religion into studies of liberalism, this dissertation, then, has attempted to show how, at various times, in sometimes inconsistent and messy ways, Irish Catholic voluntary associations in nineteenth-century Canada advanced the Canadian liberal order.

Early Irish societies like the Charitable Irish Society in Halifax and the Benevolent Irish Society in St John's were ecumenical. They were comprised of individuals with a shared Irish ancestry, and provided mutual aid for members, as well as networks of both personal acquaintances and business associates. However, in the context of the growing conservatism of the Catholic Church in revolutionary Europe, previously non-sectarian organizations underwent a process of Catholicization as ultramontane clerics extended papal influence and assumed control of church property and associations from the laity.

Clerical power was especially prevalent in temperance societies. Brian Clarke identified the sacramentalization ${ }^{8}$ of the Catholic temperance movement, and this study has

\footnotetext{
Ibid, 11.

Heaman, "Rights Talk and the Liberal Order Framework," 163.

8 Brian Clarke, Piety and Nationalism: Lay Voluntary Associations and the Creation of an Irish-Catholic Community in Toronto, 1850-1895, (Montreal and Kingston: McGill-Queen's University Press, 1993), 1323.
} 
attempted to build upon his groundbreaking research. Irish Catholic temperance associations were spaces controlled by the Church aimed at instilling ultramontane principles in members and intended to construct a parallel Catholic subculture. The dominant role of the clergy in the Irish Catholic temperance movement meant that it developed quite differently from its Protestant counterparts. Most strikingly, the Protestant temperance movement's shift from moral suasion to legislative regulation was not paralleled within Catholic temperance circles. Clerical control, the advent of ultramontanism, and the devotional revolution meant Catholic temperance was shaped by theological arguments more than arguments about state-enforced regulatory frameworks. Catholic temperance aimed at reforming the individual and saving souls rather than reducing consumption by limiting access to liquor. Grace, devotions, and the sacraments were the path to regeneration and salvation, rather than the collective selfhelp espoused by Protestant temperance societies. In arguing against the inherent evil of alcohol and against state prohibition the Church cast itself as the guide and champion of the self-regulating individual and the state as the exerciser of tyrannical power against the rights of individuals. The clerics challenged state formation by resisting the extension of state control of social institutions such as schools and workhouses and denied the state moral and institutional jurisdiction over the lives of Catholics.

Though these societies were headed by the clergy, the laity provided active leadership, and they promoted liberal values. These organizations functioned as adaptive mechanisms for Irish Catholics, in which members could define and prescribe class values and ethnic identity and assert a widespread sense of common identity. Irish Catholic temperance societies were made up of individuals from a range of classes. Local business luminaries like Montreal's Edward Murphy and Owen McGarvey or Ottawa’s John Heney were office-holders in temperance societies, and used their positions to legitimize their place 
as community leaders. That elite temperance officials like Murphy, Heney, and McGarvey strove to inculcate liberal, middle-class values through temperance, suggests that Irish temperance adheres to the argument of Greer and Radforth regarding voluntary associations being spaces within which middle-class values were legitimated, normalized and disseminated, and in which members were trained in the practices of respectability as selfgoverning individuals through reading rooms, the promotion of temperate behaviour and hard work in order to uplift their community. ${ }^{9}$

Officers lists of the temperance societies support Brian Clarke's findings in Toronto that temperance societies welcomed labourers and other members of the working class as office-holders by the 1860s. In fact, Darren Ferry and Brian Clarke are in accord with respect to the similar class membership and evolutionary stages of Protestant and Catholic temperance societies. In both instances, organizations shifted from pledge societies to skilled workers' mutual benefit fraternalist societies by the 1840 s and 1850 s. Ferry sees this evolution having been accomplished with the organization of the Sons of Temperance in 1848 , a society that recruited largely from the working classes through a message of personal uplift, the provision of insurance benefits, and also the opportunity to participate in alternative social attractions. ${ }^{10}$ Clarke argued that temperance societies in Toronto had a strong working class presence, and he likewise credits both the message of self-improvement and participation in organized recreation as keys to drawing male members into the societies. ${ }^{11}$ Clarke has argued that the recreational sociability which attracted males to Catholic temperance was part of a strategy employed by the clergy to compete with tavern sociability and draw men into a Catholic cultural world, ${ }^{12}$ similar to what Jan Noel argued

9 Greer and Radforth, Colonial Leviathan, 6.

10 Ferry, Uniting in Measures of Common Good, 102-103.

11 Clarke, Piety and Nationalism, 143-144.

12 Ibid. 
Charles Chiniquy's temperance campaign did in Quebec around the same time. ${ }^{13}$ Thus behind a leavening of clerical control, Catholic temperance societies, like their Protestant counterparts, promoted both moral and economic uplift and in doing so demonstrated their members' capacity to govern others.

Temperance was also a means of establishing and maintaining norms of gendered behaviour. Gender is relational, and the prescriptions regarding gendered behaviour shaped male and female experience alike. St Patrick's Day parades, for instance, were public expressions of masculinity where a manliness that hinged on respectability and selfgovernment became tied to class and ethnic identities and was meant to sharply distinguish the respectable from representations of the "wild, drunken Irish." For women, charitable enterprises such as bazaars were spaces through which feminine ideals of domesticity were naturalized and performed. Women were involved in early temperance societies, but the clerical takeover of these organizations resulted in their reformation as male bastions. As Clarke tells us, the ultramontanes did involve women in devotional exercises in the home and in the parish church, while raising their domestic and maternal roles to the status of a divine mission with the Blessed Virgin Mary acting as an exemplar, much as Christ performed the same role for Irish Catholic men. And as the Seal of the Montreal St Patrick's Total Abstinence Society so clearly illustrates, ideal masculinity and ideal femininity were complementary and mutually supportive. Clerical influence and expressions of middle-class, liberal values thus led to the conclusion that Irish temperance advanced the seemingly irreconcilable twin pillars of ultramontanism and liberalism.

Attacks on Irish Catholic ethno-religious identity were countered through efforts to demonstrate their self-regulation. Amidst the Fenian threat in 1866, differing responses to

13 Jan Noel, "Dry Patriotism: The Chiniquy Crusade," Canadian Historical Review 71, no. 2 (1990): 205. 
the Raids emerged. Some, led by Thomas Darcy McGee, called for Irish Catholics to redouble their efforts to demonstrate their status as liberal individuals loyal to crown and country. The "duty of the hour," it was argued, centred on distancing themselves from the Fenian menace. The response of John Lawrence Power O'Hanly and Patrick Boyle to the raids was far more combative. They opposed what they saw as the illiberal persecution of all Irish Catholics simply because of their ethno-religious identity. They were especially critical about the suspension of habeas corpus in the aftermath of the raids, and viewed this action as a betrayal of legal liberalism and the duty of the state to protect its citizens.

What is fascinating is that despite this, O'Hanly and Boyle contributed to the liberal and British ethos in the Canadian state through their support for, and participation in, settler colonialism. S.B. Cook has argued that the most typical Irish Catholic engagement with the British Empire was supportive, and we can see this in Boyle and O'Hanly. Boyle along with Peter O'Leary promoted colonization societies and temperance as ways to advance a liberal moral regime. For instance, in his temperance rhetoric, Boyle linked the success of Irish settlers in the Canadian North-West to abstinence, hard work, and thrift. O'Hanly's work as an engineer and land surveyor projected dominant European meanings onto the land and extended a liberal property regime, which Ian McKay has called a fundamental tenet of the classical liberal order from the 1840 s to the $1940 \mathrm{~s},{ }^{14}$ into indigenous space. This work extended the Canadian state and created exclusions in the liberal order even as he critiqued the exclusion of the Irish. O'Hanly distinguished Irish victimization from the marginalization of the aboriginal population. He opposed government policies toward aboriginals because he felt they created a sense of dependency rather than instilling a sense of individualism. While he believed that "civilizing" the native population was necessary, he felt that that process

14 McKay, "Canada as a Long Liberal Revolution," 376. 
should create responsible, independent individuals. Only through liberal colonial practices, O'Hanly reasoned, would aboriginals ever become autonomous individuals. For O'Hanly, then, western expansion was a benevolent liberal project. He felt that Irish victimization differed from the colonial practices he espoused toward the aboriginal population because the Irish, especially professional, liberal men like himself, were already civilized.

It was therefore the moral advantages of colonialism, as well as the economic, that O'Hanly and Boyle advanced. O'Hanly and Boyle were motivated in equal measure by a commitment to the Irish Catholic community and a belief in middle-class values and liberalism. Though these exercises in settler colonialism extended the dominion of the British Empire, O'Hanly and Boyle would have resisted the notion. Their colonialism was tied to their belief in advancing the liberal order with its emphasis on the liberal values of individualism, independence, and self-improvement.

Organized partly in response to the Fenian Raids, and as a way to improve what they viewed as their diminished status in Canada, the Catholic League was a domestic ethnopolitical organization that advocated for increased Irish Catholic representation in political office and the civil service. Applying a "scientific method," a liberal technology of governance, to explore the political standing of Irish Catholics in Canada, O'Hanly statistically demonstrated that the logical political party for Irish Catholics to throw their support behind was the Liberals. O'Hanly found that since 1854, Irish support for the Conservatives had put them at the mercy of Orange influence within that party. ${ }^{15}$ The Catholics' loss of political capital—accumulated in part through temperance work that demonstrated their self-governing capacity — was accompanied by anxiety that Confederation would add another political level from which they would be excluded. The

15 John Lawrence Power O'Hanly, The Political Standing of Irish Catholics in Canada, A Critical Analysis of its Causes, With Suggestions for its Amelioration, CIHM 23746, 54. 
formation of the Catholic League was meant to remedy this state of affairs. These Irish remonstrations occurred within the context of larger debates regarding bureaucratic transformations which sought to reimagine the civil service as a politically neutral meritocracy, managed by objective, efficient, rational professionals ${ }^{16}$ in a rational state apparatus.

The Catholic League's participation in these debates highlights one of the key exclusions from the liberal state and how the ethno-religious position of Irish Catholics shaped expressions of liberalism. O’Hanly argued that Irish Catholics qualified for appointments under the new reforming standards, but were excluded because of Orange political influence. The Catholic League sought not to rationalize or modernize the civil service or system of government, but instead to insinuate more Irish Catholics into the state apparatus as a temporary illiberal measure until their ethno-religious identity would no longer prove a barrier to advancement. Only at that point, O'Hanly argued, could a genuine meritocracy be implemented. O’Hanly employed the rhetoric of liberalism and rational government even as he argued in favour of the apparent irrationality of ethno-religious block voting.

Though still fighting the struggle for political representation, by the 1880 s the concerns of the Canadian Irish had shifted to Ireland and the movement for Home Rule. The Irish Home Rule movement had a chance of achieving broad acceptance in the wider society because it advocated for self-government within the Empire, something already enjoyed in the colonies. Home Rule's emphasis on constitutional reform and an overhaul of the land tenure system in Ireland, rather than violent revolution, made this incarnation of Irish nationalism a palatable and legitimate endeavor in the eyes of liberal Canadian society.

16 David Banoub, "The Patronage Effect: Civil Service Reforms, Job-Seeking, and State Formation in Victorian Canada," (PhD diss., Carleton University, 2013), 3. 
While Home Rule implicitly challenged imperial rule by agitating for Ireland's semiindependence from the British Empire, supporters framed their political platform in liberal, rather than nationalist or religious terms. Canadian supporters of Irish Home Rule cast Irish self-government in similar terms to the establishment of Canadian responsible government in the 1840 s, which was a seminal moment in the development of the liberal order. Framed in liberal terms, Canadian liberals had little choice but to support Irish Home Rule.

While Home Rule allowed the Irish Catholic voluntary movement to demonstrate their liberal credentials, the issue was made difficult as Home Rule became radicalized when the leadership shifted from the pro-imperial Isaac Butt to the militant Charles Parnell. While liberals in Canada, such as the editor of the Globe, continued to support Irish Home Rule, they opposed Parnell and supported his arrest in 1881. Despite the censure that Parnell received from mainstream Canada, Home Rule and Land League branches in Canada continued to back Parnell. Thus, when John Costigan was gearing up to introduce resolutions in support of Home Rule in the Canadian Parliament, O'Hanly organized Irish Catholic voluntary associations of every conceivable description to lend support. Costigan framed the Resolutions, and the discourse surrounding Home Rule at this juncture, in liberal constitutional terms and in terms of the Canadian examples of responsible government and freehold property rights. The resolutions emphasized the need for liberal reforms to the Irish land system and employed liberal rhetoric that would appeal to Canadians. On a general level it would have been difficult for Canadian politicians to oppose the Irish Home Rule movement. Irish Home Rulers aimed to establish an Irish political state akin to the Canadian Dominion: autonomous in domestic affairs, yet still a part of the British Empire. They thus linked the demand for Irish self-government with the Canadian liberal order.

Still, Canadian cultural and political realities forced them to moderate their support. 
At Macdonald's insistence, references to Parnell were excised from Costigan's text. In return for the moderated tone of the resolutions, Macdonald recruited Costigan, Frank Smith, and John O'Donohoe into his government. David Shanahan has argued that this move was an example of Macdonald's political shrewdness as it guaranteed their support, as well as the support from many within the Canadian Irish Catholic community. ${ }^{17}$ Yet it also demonstrated the political pragmatism of the trio and their recognition that in order to be included in the Canadian liberal order they would have to compromise their stance. The passing of the resolutions indicates that a liberal consensus between the Irish community and the wider society was emerging on the Irish question.

Despite ethnic identity being a central element in Irish Catholic voluntary associations, distinguishing these societies from the mainstream societies studied by Greer and Radforth, McNairn, and Ferry, Irish organizations did not cut members off from the wider society. Rather, these associations allowed members to retain their Irishness and rework that sense of identity within the liberal Canadian culture of which they were a growing and influential part. The voluntary associations under review in this study were responding to specific conditions in Canada and abroad. They were utilized by ultramontane clerics to achieve positions of community control, and by lay Irish Catholics to achieve cultural integration or acceptance by expressing liberal values that were recognizable within a liberal social structure. In so doing, Irish Catholic voluntary associations helped advance the Canadian political establishment.

17 David Shanahan, "The Irish Question in Canada: Ireland, the Irish and Canadian Politics: 1880-1922," (PhD diss. Carleton University, 1989), 69. 


\section{$\underline{\text { Appendix A }}$}

\section{The 1882 Home Rule Resolutions ${ }^{1}$}

We, Your Majesty's most dutiful and loyal subjects, the Commons of Canada, in Parliament assembled, desire most earnestly, in our own name, and on behalf of the people whom we represent, to renew the expression of our unswerving loyalty and devotion to Your Majesty's person and Government.

1. We have observed, may it please Your Majesty, with feelings of profound regret and concern, the distress and discontent which have prevailed for some time among Your Majesty's subjects in Ireland.

2. We would respectfully represent to Your Majesty that your Irish subjects in the Dominion of Canada are among the most loyal, most prosperous, and most contented of Your Majesty's subjects.

3. We would further respectfully represent to Your Majesty that the Dominion of Canada, while offering the greatest advantages and attractions for those of our fellow-subjects who may desire to make their homes amongst us, does not receive that proportion of emigrants from Ireland which might reasonably be expected and that this is due, in a great measure, in the case of many of our Irish fellow-subjects who have sought foreign homes, to their feelings of estrangement towards the Imperial Government.

4. We would further most respectively represent to Your Majesty that in the interests of this your loyal Dominion, and of the entire Empire, it Is extremely to be desired that Your Majesty may not be deprived in the development of Your Majesty's possessions on this continent of the valuable aid of those of Your Majesty's Irish subjects who may feel disposed to leave their native land to seek more prosperous homes.

5. We desire respectfully to suggest to Your Majesty that Canada and its inhabitants have prospered exceedingly under a Federal system, allowing to each Province of the Dominion considerable powers of self-government, and would venture to express a hope that if consistent with the integrity and well being of the Empire, and if the rights and status of the minority are fully protected and secured, some means may be found of meeting the expressed desire of many of Your Irish subjects in that regard, so that Ireland may become a source of strength to Your Majesty's Empire, and that Your Majesty's Irish subjects at home and abroad may feel - the same pride in the greatness of Your Majesty's Empire, the same veneration for the justice of Your Majesty's rule, and the same devotion to, and affection for our common flag, as are now felt by all classes of Your Majesty's loyal subjects in this Dominion.

6. We would further express a hope that the time has come when Your Majesty's clemency may without injury to the interests of the United Kingdom be extended to those persons Who

1 Local Self Government for Ireland, Speech Delivered by Mr John Costigan, M.P. In the House of Commons of Canada, Thursday April 20, 1882. Online, https://archive.org/stream/cihm_04179\#page/n9/mode/2up, p. 8. Last accessed 31 March 2016. 
are now imprisoned in Ireland charged with political offences only, and the inestimable blessing of personal liberty restored to them.

We pray that the blessings of Your Majesty's Reign may, for your people's sake, be long continued. 


\section{Appendix B}

$\underline{\text { Seal of the St Patrick's Total Abstinence Society, Montreal }}{ }^{1}$

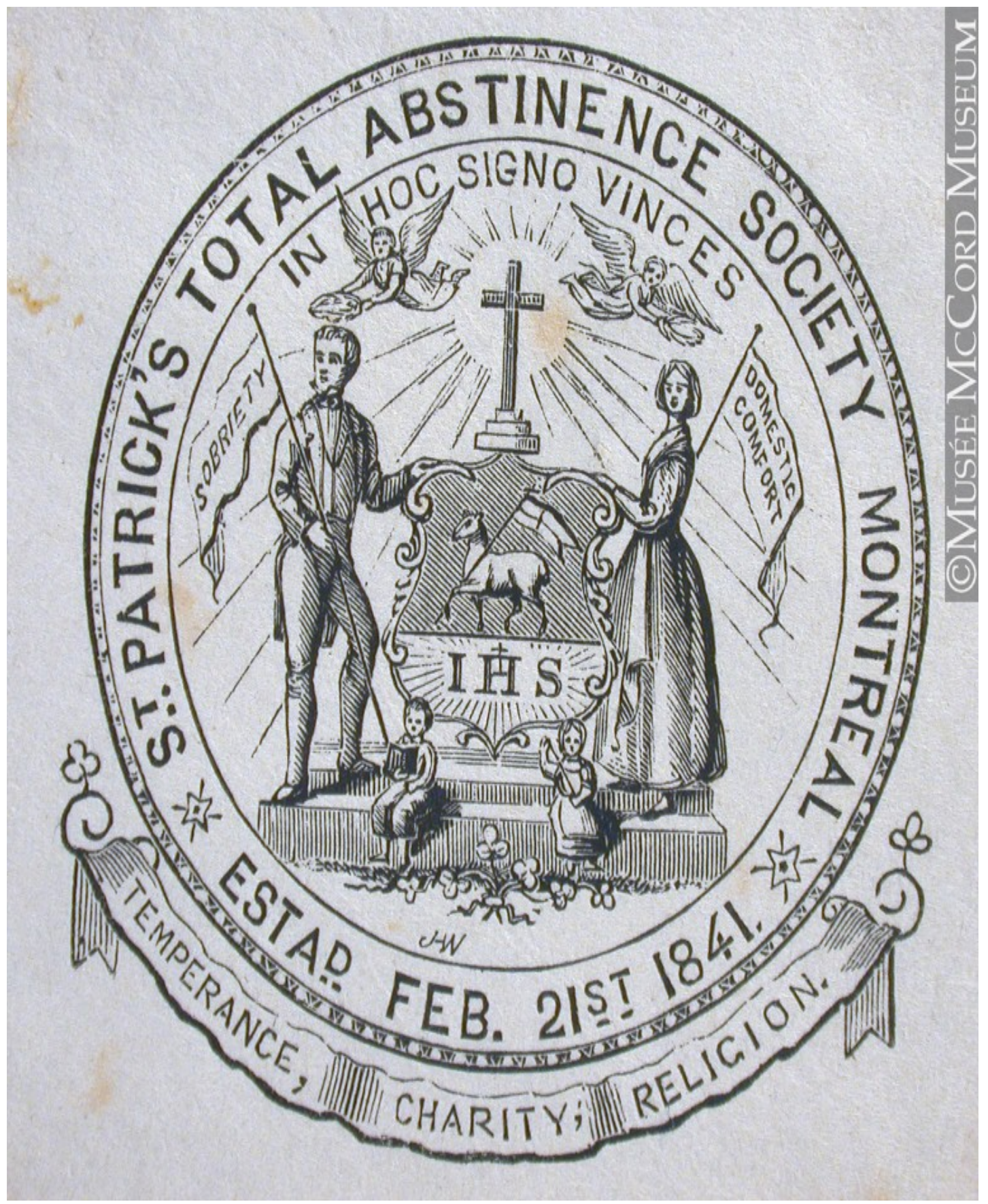

McCord Museum of Canadian History, M930-50-1-580, Seal of the St Patrick's Total Abstinence Society. 


\section{$\underline{\text { Appendix C }}$}

Officers of Irish Catholic Voluntary Associations in Montreal, 1842-1880. ${ }^{1}$

\begin{tabular}{|c|c|c|c|c|c|}
\hline Year & Associations & $\begin{array}{l}\text { Officers } \\
\text { Listed }\end{array}$ & Occupation & $\begin{array}{l}\text { Family } \\
\text { Status }\end{array}$ & Birthplace \\
\hline $1842-43$ & $\begin{array}{l}\text { St Patrick's } \\
\text { Society }\end{array}$ & 3 & $\begin{array}{l}\text { Bank Cashier } \\
\text { Merchant } \\
\text { Shoemaker } \\
\text { Grocer }\end{array}$ & & \\
\hline $1845-46$ & $\begin{array}{l}\text { St Patrick's } \\
\text { Society }\end{array}$ & 33 & $\begin{array}{l}9 \text { Merchants } \\
3 \text { Grocers } \\
2 \text { Clergy } \\
\text { Politician } \\
\text { Teacher } \\
\text { Tailor } \\
\text { Painter } \\
\text { Lawyer } \\
\text { Messenger } \\
\text { Clerk } \\
\text { Journalist } \\
\text { Mason } \\
\text { Farmer } \\
\text { Stevedore } \\
\text { Coach-builder } \\
\text { Cattle-dealer } \\
\text { Tavern-owner } \\
\text { Horse-shoer } \\
\text { Court crier } \\
\text { Labourer. }\end{array}$ & & \\
\hline $1845-46$ & $\begin{array}{l}\text { Irish Catholic } \\
\text { Temperance } \\
\text { Society }\end{array}$ & 8 & $\begin{array}{l}3 \text { Clergy } \\
2 \text { Merchants } \\
\text { Messenger } \\
\text { Blacksmith }\end{array}$ & & \\
\hline 1850 & $\begin{array}{l}\text { St Patrick's Total } \\
\text { Abstinence } \\
\text { Society }\end{array}$ & 3 & $\begin{array}{l}2 \text { Clergy } \\
\text { Merchant }\end{array}$ & $1 \mathrm{Md}$. & 2 Ireland \\
\hline
\end{tabular}

1 The Montreal Directory for 1842-3, (Montreal: Lovell \& Gibson, 1843); The Montreal Directory, Corrected in May, 1850. (Montreal: Lovell and Gibson, 1850); The Montreal Directory, New Edition, Corrected in May and June 1855. (Montreal: Owler \& Stevenson, 1855); MacKay's Montreal Directory, New Edition, Corrected in May and June, 1860-61, (Montreal: Owler \& Stevenson, 1861); MacKay's Montreal Directory for 1865-6, (Montreal: John Lovell, 1866); Montreal Directory for 1870-1871, (Montreal: John Lovell, 1870); Lovell's Montreal Directory for 1875-76, (Montreal: John Lovell, 1876); Lovell's Montreal Directory for 1880-81, (Montreal: John Lovell \& Son, 1881). 


\begin{tabular}{|c|c|c|c|c|c|}
\hline 1855 & $\begin{array}{l}\text { St Patrick's } \\
\text { Society }\end{array}$ & 15 & $\begin{array}{l}2 \text { Merchants } \\
\text { Shoemaker } \\
\text { Factory-owner } \\
\text { Customs Collector }\end{array}$ & & \\
\hline 1861 & $\begin{array}{l}\text { St Patrick's } \\
\text { Literary Society }\end{array}$ & 7 & $\begin{array}{l}\text { Clergy } \\
\text { Labourer } \\
\text { Journalist } \\
\text { Law Student }\end{array}$ & $\begin{array}{l}1 \mathrm{Md} . \\
1 \mathrm{Unm} .\end{array}$ & $\begin{array}{l}2 \text { Ireland } \\
1 \text { Canada }\end{array}$ \\
\hline 1861 & $\begin{array}{l}\text { St Patrick's } \\
\text { Society }\end{array}$ & 32 & $\begin{array}{l}7 \text { Grocers } \\
3 \text { Merchants } \\
2 \text { Tavern-keepers } \\
2 \text { Clerks } \\
\text { Plumber and gas- } \\
\text { fitter } \\
\text { Doctor } \\
\text { Lawyer } \\
\text { Auctioneer } \\
\text { Tailor } \\
\text { Notary } \\
\text { Labourer. }\end{array}$ & $\begin{array}{l}2 \mathrm{Md} . \\
2 \text { Unm. }\end{array}$ & $\begin{array}{l}3 \text { Ireland } \\
2 \text { Canada }\end{array}$ \\
\hline 1861 & $\begin{array}{l}\text { St Patrick's Total } \\
\text { Abstinence } \\
\text { Society }\end{array}$ & 18 & $\begin{array}{l}2 \text { Merchants } \\
2 \text { Grocers } \\
\text { Clergy } \\
\text { Civil service } \\
\text { Bricklayer } \\
\text { Clerk } \\
\text { Plumber and gas- } \\
\text { fitter } \\
\text { Bookkeeper. }\end{array}$ & $\begin{array}{l}4 \text { Md. } \\
2 \text { Unm. }\end{array}$ & 6 Ireland \\
\hline 1866 & $\begin{array}{l}\text { St Patrick's } \\
\text { Benevolent } \\
\text { Society }\end{array}$ & 11 & $\begin{array}{l}\text { Tanner } \\
\text { Merchant } \\
\text { Boilermaker } \\
\text { Contractor } \\
\text { Painter } \\
\text { Labourer } \\
\text { Policeman }\end{array}$ & & \\
\hline 1866 & $\begin{array}{l}\text { St Patrick's } \\
\text { Literary Society }\end{array}$ & 5 & $\begin{array}{l}\text { Merchant } \\
\text { Grocer } \\
\text { Clergy }\end{array}$ & & \\
\hline 1866 & $\begin{array}{l}\text { St Patrick's } \\
\text { Society }\end{array}$ & 33 & $\begin{array}{l}7 \text { Merchants } \\
3 \text { Grocers } \\
2 \text { Clerks } \\
2 \text { Saloon-keepers } \\
\text { Lawyer }\end{array}$ & & \\
\hline
\end{tabular}




\begin{tabular}{|c|c|c|c|c|c|}
\hline & & & $\begin{array}{l}\text { Brewer } \\
\text { Gasfitter- } \\
\text { steamfitter } \\
\text { Tailor } \\
\text { Shoe-maker } \\
\text { Marble-cutter } \\
\text { Machinist } \\
\text { Stevedore } \\
\text { Printer }\end{array}$ & & \\
\hline 1866 & $\begin{array}{l}\text { St Patrick's Total } \\
\text { Abstinence } \\
\text { Society }\end{array}$ & 31 & $\begin{array}{l}3 \text { Merchants } \\
2 \text { Grocers } \\
\text { Clergy } \\
\text { Collector } \\
\text { Tanner } \\
\text { Cabinet-maker } \\
\text { Cooper } \\
\text { Dyer } \\
\text { Carpenter } \\
\text { Shoe-maker } \\
\text { Boilermaker } \\
\text { Painter } \\
\text { Broom-maker }\end{array}$ & & \\
\hline 1870 & $\begin{array}{l}\text { Catholic Young } \\
\text { Men's Society }\end{array}$ & 17 & $\begin{array}{l}5 \text { Merchants } \\
2 \text { Grocers } \\
\text { Clergy } \\
\text { Accountant } \\
\text { Artist } \\
\text { Clerk } \\
\text { Labourer }\end{array}$ & $\begin{array}{l}4 \mathrm{Md} . \\
4 \mathrm{Unm} .\end{array}$ & $\begin{array}{l}6 \text { Ireland } \\
1 \text { England } \\
1 \text { Canada }\end{array}$ \\
\hline 1870 & $\begin{array}{l}\text { St Patrick's } \\
\text { Benevolent } \\
\text { Society }\end{array}$ & 24 & $\begin{array}{l}5 \text { Merchants } \\
\text { Chandler } \\
\text { Shoe-maker } \\
\text { Contractor } \\
\text { Labourer } \\
\text { Bread-driver } \\
\text { Banker } \\
\text { Soap-maker } \\
\text { Cabinet-maker } \\
\text { Cooper }\end{array}$ & $\begin{array}{l}10 \mathrm{Md} . \\
1 \text { Wid. }\end{array}$ & 12 Ireland \\
\hline 1870 & $\begin{array}{l}\text { St Patrick's } \\
\text { Society }\end{array}$ & 36 & $\begin{array}{l}8 \text { Merchants } \\
\text { Lawyer } \\
\text { Brewer } \\
\text { Grocer } \\
\text { Civil service } \\
\text { Boot and shoe }\end{array}$ & $\begin{array}{l}1 \mathrm{Md} . \\
2 \mathrm{Unm} .\end{array}$ & $\begin{array}{l}10 \text { Ireland } \\
2 \text { Canada }\end{array}$ \\
\hline
\end{tabular}




\begin{tabular}{|c|c|c|c|c|c|}
\hline & & & $\begin{array}{l}\text { manufacturer } \\
\text { Gas and steam } \\
\text { fitter } \\
\text { Politician } \\
\text { Manufacturer }\end{array}$ & & \\
\hline 1870 & $\begin{array}{l}\text { St Ann's } \\
\text { Temperance } \\
\text { Society }\end{array}$ & 3 & $\begin{array}{l}\text { Clergy } \\
\text { No occupation } \\
\text { Contractor }\end{array}$ & $2 \mathrm{Md}$. & 3 Ireland \\
\hline 1870 & $\begin{array}{l}\text { St Bridget's Total } \\
\text { Abstinence and } \\
\text { Benefit Society }\end{array}$ & 8 & $\begin{array}{l}\text { Clergy } \\
\text { Manufacturer } \\
\text { Merchant } \\
\text { Grocer } \\
\text { Crockery } \\
\text { Shoemaker } \\
\text { Policeman }\end{array}$ & $\begin{array}{l}5 \mathrm{Md} . \\
1 \mathrm{Unm} .\end{array}$ & $\begin{array}{l}5 \text { Ireland } \\
1 \text { France } \\
1 \text { Canada }\end{array}$ \\
\hline 1870 & $\begin{array}{l}\text { St Patrick's Total } \\
\text { Abstinence } \\
\text { Society }\end{array}$ & 29 & $\begin{array}{l}\text { 4 Merchants } \\
\text { Clergy } \\
\text { Gas and steam } \\
\text { fitter } \\
\text { Architect } \\
\text { Detective } \\
\text { Blacksmith } \\
\text { Notary } \\
\text { Engineer } \\
\text { Boilermaker } \\
\text { Tailor } \\
\text { Cabinet-maker } \\
\text { Grocer } \\
\text { Military } \\
\text { Tailor } \\
\text { Civil service } \\
\text { Labourer } \\
\text { Trunk-maker }\end{array}$ & $\begin{array}{l}13 \mathrm{Md} . \\
1 \mathrm{Unm} .\end{array}$ & $\begin{array}{l}14 \text { Ireland } \\
1 \text { Canada }\end{array}$ \\
\hline 1875 & $\begin{array}{l}\text { St Patrick's } \\
\text { Society }\end{array}$ & 37 & $\begin{array}{l}5 \text { Grocers } \\
4 \text { Merchants } \\
\text { Lawyer } \\
\text { Police sergeant } \\
\text { Contractor } \\
\text { Clerk } \\
\text { Cooper } \\
\text { City clerk } \\
\text { Bailiff superior } \\
\text { court } \\
\text { Butcher } \\
\text { Customs officer }\end{array}$ & & \\
\hline
\end{tabular}




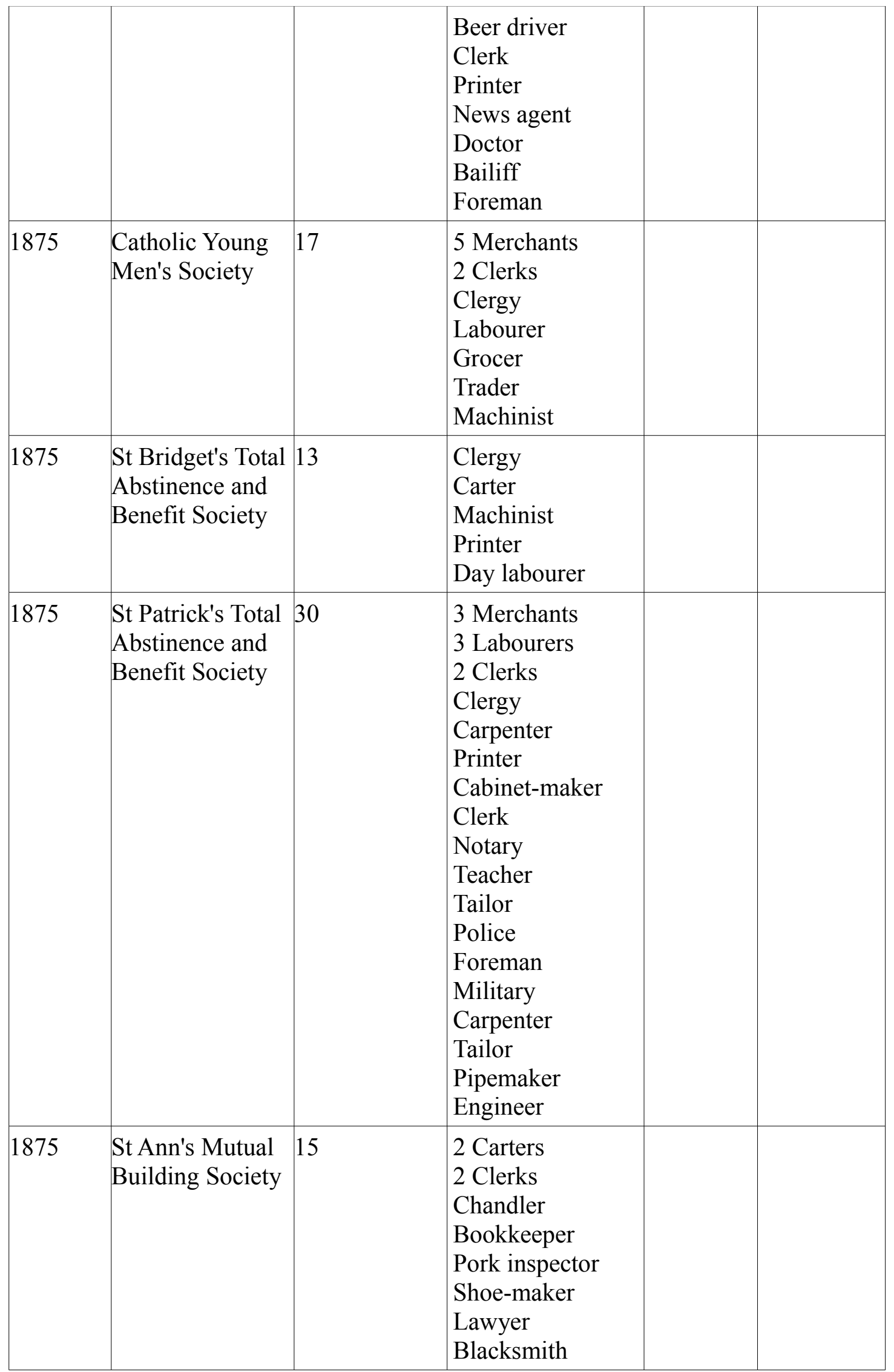




\begin{tabular}{|c|c|c|c|c|c|}
\hline & & & $\begin{array}{l}\text { Printer } \\
\text { Boot-crimper } \\
\text { Clerk } \\
\text { Tailor } \\
\text { Labourer } \\
\text { Architect }\end{array}$ & & \\
\hline 1880 & $\begin{array}{l}\text { Irish Catholic } \\
\text { Benefit Society }\end{array}$ & 11 & \begin{tabular}{|l}
3 Clerks \\
Hotelier \\
Dyer \\
Labourer \\
Engineer
\end{tabular} & $\begin{array}{l}3 \mathrm{Md} . \\
1 \mathrm{Unm} .\end{array}$ & $\begin{array}{l}3 \text { Ireland } \\
1 \text { England } \\
1 \text { Canada }\end{array}$ \\
\hline 1880 & $\begin{array}{l}\text { St Patrick's } \\
\text { Benevolent } \\
\text { Society }\end{array}$ & 9 & $\begin{array}{l}\text { Saddler } \\
\text { Plumber } \\
\text { Carter }\end{array}$ & $3 \mathrm{Md}$. & 6 Ireland \\
\hline 1880 & $\begin{array}{l}\text { Young Irishmen's } \\
\text { Literary and } \\
\text { Benefit Society }\end{array}$ & 11 & $\begin{array}{l}2 \text { Clerks } \\
\text { Shoemaker } \\
\text { Engineer } \\
\text { Waiter }\end{array}$ & $\begin{array}{l}3 \mathrm{Md} . \\
3 \mathrm{Unm} .\end{array}$ & $\begin{array}{l}3 \text { Ireland } \\
1 \text { Canada }\end{array}$ \\
\hline 1880 & $\begin{array}{l}\text { Irish Mutual } \\
\text { Building Society }\end{array}$ & 10 & $\begin{array}{l}2 \text { Merchants } \\
\text { Railway freight } \\
\text { attendant } \\
\text { Grocer } \\
\text { Clerk }\end{array}$ & $\begin{array}{l}2 \mathrm{Md} . \\
3 \mathrm{Unm} .\end{array}$ & $\begin{array}{l}3 \text { Ireland } \\
1 \text { Canada }\end{array}$ \\
\hline 1880 & $\begin{array}{l}\text { St Ann's Mutual } \\
\text { Building Society }\end{array}$ & 6 & $\begin{array}{l}\text { Chandler } \\
\text { Grocer } \\
\text { Provision } \\
\text { Inspector }\end{array}$ & $3 \mathrm{Md}$. & $\begin{array}{l}3 \text { Canada } \\
1 \text { Ireland }\end{array}$ \\
\hline 1880 & $\begin{array}{l}\text { St Patrick's } \\
\text { Society }\end{array}$ & 35 & $\begin{array}{l}7 \text { Merchants } \\
2 \text { Doctors } \\
\text { Professor } \\
\text { Catholic } \\
\text { commercial } \\
\text { academy } \\
\text { Clerk } \\
\text { Real estate and } \\
\text { collecting agent } \\
\text { Customs officer } \\
\text { Milkman } \\
\text { Labourer } \\
\text { Printer } \\
\text { Plasterer } \\
\text { Bricklayer } \\
\text { Baker }\end{array}$ & $\begin{array}{l}13 \mathrm{Md} . \\
2 \mathrm{Unm} .\end{array}$ & $\begin{array}{l}14 \text { Ireland } \\
1 \text { Canada } \\
1 \text { United } \\
\text { States }\end{array}$ \\
\hline
\end{tabular}




\begin{tabular}{|c|c|c|c|c|c|}
\hline & & & $\begin{array}{l}\text { Foreman } \\
\text { Draughtsman }\end{array}$ & & \\
\hline 1880 & $\begin{array}{l}\text { St Ann's Total } \\
\text { Abstinence and } \\
\text { Benefit Society }\end{array}$ & 21 & $\begin{array}{l}2 \text { Labourers } \\
\text { Clergy } \\
\text { Engineer } \\
\text { Printer } \\
\text { Shoemaker } \\
\text { Blacksmith } \\
\text { Contractor } \\
\text { Watchmaker } \\
\text { Leather-cutter } \\
\text { Foreman }\end{array}$ & $\begin{array}{l}10 \mathrm{Md} . \\
1 \text { Wid. }\end{array}$ & 7 Ireland \\
\hline 1880 & $\begin{array}{l}\text { St Bridget's Total } \\
\text { Abstinence and } \\
\text { Benefit Society }\end{array}$ & 13 & $\begin{array}{l}\text { Clergy } \\
\text { Real estate and } \\
\text { collection agent } \\
\text { Labourer } \\
\text { Grocer } \\
\text { Merchant } \\
\end{array}$ & $\begin{array}{l}1 \mathrm{Md} . \\
1 \mathrm{Unm} . \\
1 \mathrm{Wid} .\end{array}$ & $\begin{array}{l}3 \text { Ireland } \\
1 \text { United } \\
\text { States }\end{array}$ \\
\hline 1880 & $\begin{array}{l}\text { St Gabriel's Total } \\
\text { Abstinence and } \\
\text { Benefit Society }\end{array}$ & 19 & $\begin{array}{l}3 \text { Labourers } \\
\text { Clergy } \\
\text { Machinist } \\
\text { Boilermaker } \\
\text { Clerk } \\
\text { Contractor }\end{array}$ & $\begin{array}{l}4 \mathrm{Md} . \\
3 \mathrm{Unm} .\end{array}$ & $\begin{array}{l}5 \text { Ireland } \\
1 \text { Canada }\end{array}$ \\
\hline 1880 & $\begin{array}{l}\text { St Patrick's Total } \\
\text { Abstinence and } \\
\text { Benefit Society }\end{array}$ & 30 & $\begin{array}{l}3 \text { Labourers } \\
2 \text { Merchants } \\
\text { Clergy } \\
\text { Builder } \\
\text { Engineer } \\
\text { Tailor } \\
\text { Clerk } \\
\text { Pipemaker } \\
\text { Notary } \\
\text { Mason } \\
\text { Coachman } \\
\text { Tuner } \\
\text { Carpenter }\end{array}$ & $\begin{array}{l}9 \mathrm{Md} . \\
3 \mathrm{Unm} . \\
2 \text { Wid. }\end{array}$ & $\begin{array}{l}16 \text { Ireland } \\
1 \text { Canada }\end{array}$ \\
\hline
\end{tabular}




\section{$\underline{\text { Appendix D }}$}

Officers of Irish Catholic Voluntary Associations in Ottawa, 1864-1880 ${ }^{1}$

\begin{tabular}{|c|c|c|c|c|c|}
\hline Year & Associations & Occupation & $\begin{array}{l}\text { Officers } \\
\text { Listed }\end{array}$ & $\begin{array}{l}\text { Family } \\
\text { Status }\end{array}$ & Birthplace \\
\hline $1864-65$ & $\begin{array}{l}\text { St Patrick's Literary } \\
\text { Association }\end{array}$ & $\begin{array}{l}\text { Teacher } \\
\text { Civil service } \\
\text { Blacksmith } \\
\text { Bookkeeper } \\
\text { Lawyer } \\
\text { Merchant } \\
\text { Clerk } \\
\text { Contractor } \\
\text { Tool-keeper } \\
\text { Tailor } \\
\text { Blacksmith } \\
\text { Shoe-maker } \\
\text { Grocer } \\
\text { Carpenter }\end{array}$ & 19 & & \\
\hline $1864-65$ & $\begin{array}{l}\text { Irish Literary } \\
\text { Debating Club }\end{array}$ & $\begin{array}{l}\text { Teacher } \\
\text { Butcher } \\
\text { Law student }\end{array}$ & 3 & & \\
\hline $1864-65$ & $\begin{array}{l}\text { Catholic Temperance } \\
\text { Society }\end{array}$ & $\begin{array}{l}\text { Clergy } \\
\text { Merchant } \\
\text { Tailor } \\
\text { Blacksmith } \\
\text { Journalist } \\
\text { Teacher }\end{array}$ & 6 & & \\
\hline $1870-71$ & $\begin{array}{l}\text { St Patrick's Literary } \\
\text { Association }\end{array}$ & $\begin{array}{l}6 \text { Merchants } \\
2 \text { Grocers } \\
2 \text { Carpenters } \\
\text { Engineer } \\
\text { Blacksmith } \\
\text { Civil service } \\
\text { Innkeeper } \\
\text { Butcher } \\
\text { Plasterer } \\
\text { Tailor }\end{array}$ & 21 & $\begin{array}{l}12 \mathrm{Md} . \\
1 \mathrm{Unm} .\end{array}$ & $\begin{array}{l}11 \text { Ireland } \\
3 \text { Canada }\end{array}$ \\
\hline $1870-71$ & Irish Catholic & 2 Teachers & 6 & $3 \mathrm{Md}$. & 4 Ireland \\
\hline
\end{tabular}

1 Mitchell \& Co.'s Carleton and Ottawa Directory 1864-5, (Ottawa: W.C. Chewett \& Co., 1865); Lovell's Province of Ontario Directory for 1871, (Montreal: John Lovell, 1871); Ottawa Directory for 1874-75, (Ottawa: A.S. Woodburn, 1875); The Ottawa Street, Alphabetical, Classified Business and Miscellaneous Directory for 1881, (Ottawa: A.S. Woodburn, 1881). 


\begin{tabular}{|c|c|c|c|c|c|}
\hline & Temperance Society & $\begin{array}{l}\text { Clergy } \\
\text { Merchant } \\
\text { Blacksmith } \\
\text { Civil Service }\end{array}$ & & & \\
\hline $1874-75$ & $\begin{array}{l}\text { St Patrick's Literary } \\
\text { Association }\end{array}$ & $\begin{array}{l}4 \text { Merchants } \\
\text { Blacksmith } \\
\text { Grocer } \\
\text { Tailor } \\
\text { Hotel-Keeper } \\
\text { Carpenter } \\
\text { Toll-Keeper } \\
\text { Butcher }\end{array}$ & 23 & & \\
\hline 1874-75 & $\begin{array}{l}\text { Irish Catholic } \\
\text { Temperance Society }\end{array}$ & $\begin{array}{l}2 \text { Merchants } \\
2 \text { Teachers } \\
\text { Clergy } \\
\text { Civil Service } \\
\text { Blacksmith. }\end{array}$ & 7 & & \\
\hline 1881 & $\begin{array}{l}\text { St Patrick's Literary } \\
\text { Association }\end{array}$ & $\begin{array}{l}2 \text { Grocers } \\
\text { Hotel-Owner } \\
\text { Tailor } \\
\text { Merchant } \\
\text { Clerk } \\
\text { Civil Service } \\
\text { Jeweller } \\
\text { Printer } \\
\text { Labourer/Blacksm } \\
\text { ith } \\
\text { Bookseller } \\
\text { Attorney }\end{array}$ & 16 & $\begin{array}{l}6 \mathrm{Md} . \\
2 \mathrm{Unm} .\end{array}$ & $\begin{array}{l}3 \text { Ireland } \\
2 \text { Canada }\end{array}$ \\
\hline 1881 & $\begin{array}{l}\text { Irish Catholic } \\
\text { Temperance Society }\end{array}$ & $\begin{array}{l}4 \text { Labourers } \\
\text { Clergy } \\
\text { Merchant } \\
\text { License Inspector } \\
\text { Undertaker } \\
\text { Clerk } \\
\text { Crown timber } \\
\text { office } \\
\text { Secretary separate } \\
\text { school board } \\
\text { Butcher/Printer } \\
\text { Letter-Carrier } \\
\text { Grocer } \\
\text { Painter/ } \\
\text { Blacksmith }\end{array}$ & 20 & $\begin{array}{l}7 \mathrm{Md} . \\
1 \mathrm{Wid} . \\
1 \mathrm{Unm} .\end{array}$ & $\begin{array}{l}5 \text { Ireland } \\
3 \text { Canada }\end{array}$ \\
\hline
\end{tabular}




\section{Appendix E}

Officers of Irish Catholic Voluntary Associations in Toronto, 1843-1877

\begin{tabular}{|c|c|c|c|c|c|}
\hline Year & Associations & Occupation & $\begin{array}{l}\text { Officers } \\
\text { Listed }\end{array}$ & $\begin{array}{l}\text { Family } \\
\text { Status }\end{array}$ & Birthplace \\
\hline $1843-44$ & $\begin{array}{l}\text { St Patrick's } \\
\text { Society }\end{array}$ & $\begin{array}{l}\text { Doctor } \\
\text { Barrister } \\
\text { Harness-Maker } \\
\text { Clergy }\end{array}$ & 6 & & \\
\hline $1850-51$ & $\begin{array}{l}\text { St Patrick's } \\
\text { Society }\end{array}$ & $\begin{array}{l}\text { President Of Toronto } \\
\text { University } \\
\text { Barrister } \\
\text { Doctor } \\
\text { Dry Goods Store } \\
\text { Gun-Maker } \\
\text { Merchant }\end{array}$ & 6 & $1 \mathrm{Md}$. & \\
\hline 1861 & $\begin{array}{l}\text { St Patrick's } \\
\text { Association }\end{array}$ & $\begin{array}{l}\text { Mayor of Toronto } \\
\text { Contractor } \\
\text { Watchmaker } \\
\text { Post Office Clerk } \\
\text { Doctor } \\
\text { Doctor } \\
\text { Banker } \\
\text { Merchant } \\
\text { Master Of Grammar School } \\
\text { Foundry Owner }\end{array}$ & 16 & $3 \mathrm{Md}$. & 4 Ireland \\
\hline 1866 & $\begin{array}{l}\text { St Patrick's } \\
\text { Society }\end{array}$ & $\begin{array}{l}7 \text { Merchants } \\
2 \text { Civil Service } \\
2 \text { Foundry Owners } \\
\text { Postmaster General } \\
\text { Engineer } \\
\text { Journalist } \\
\text { Painter } \\
\text { Doctor } \\
\text { Publisher } \\
\text { Plumber/Gas-Fitter } \\
\text { Clerk } \\
\text { Emigration Agent }\end{array}$ & 22 & & \\
\hline
\end{tabular}

Toronto Directory and Street Guide for 1843-44, (Toronto: H. \& W. Rowsell, 1844); Rowsell's City of Toronto and County of York Directory 1850, (Toronto: Henry Rowsell, 1850); Brown's Toronto General Directory 1861, (Toronto: W.C. Chewett, 1861); Mitchell \& Co.'s General Directory for the City of Toronto, and Gazetteer of the Counties of York and Peel for 1866, (Toronto: Mitchell \& Co., 1866); Lovell's Province of Ontario Directory for 1871, (Montreal: John Lovell, 1871); Toronto Directory for 1877, (Toronto: Might \& Taylor, 1877). 


\begin{tabular}{|l|l|l|l|l|l|}
\hline & & Shoe-Maker & & \\
\hline 1871 & $\begin{array}{l}\text { Hibernian } \\
\text { Society }\end{array}$ & Journalist & 3 & 1 Md. & 1 Ireland \\
\hline 1877 & $\begin{array}{l}\text { Father } \\
\text { Mathew } \\
\text { Temperance } \\
\text { Association }\end{array}$ & $\begin{array}{l}\text { Journalist } \\
\text { Builder } \\
\text { Merchant Tailor } \\
\text { Yardman } \\
\text { Law Student } \\
\text { Merchant }\end{array}$ & 7 & & \\
\hline
\end{tabular}




\section{Appendix F}

Officers of Irish Catholic Voluntary Associations in Halifax, 1871-1880

\begin{tabular}{|c|c|c|c|c|c|}
\hline Year & Associations & Occupation & $\begin{array}{l}\text { Officers } \\
\text { Listed }\end{array}$ & $\begin{array}{l}\text { Family } \\
\text { Status }\end{array}$ & Birthplace \\
\hline 1871 & $\begin{array}{l}\text { Charitable Irish } \\
\text { Society }\end{array}$ & $\begin{array}{l}\text { Alderman } \\
\text { Grocer } \\
\text { Seaman } \\
\text { Merchant }\end{array}$ & 8 & $3 \mathrm{Md}$. & 3 Canada \\
\hline 1871 & $\begin{array}{l}\text { Halifax Catholic } \\
\text { Total Abstinence } \\
\text { and Benevolent } \\
\text { Society }\end{array}$ & $\begin{array}{l}3 \text { Labourers } \\
\text { Clergy } \\
\text { Clerk } \\
\text { Baker } \\
\text { Coachman } \\
\text { Policeman } \\
\text { Seaman. }\end{array}$ & 18 & $6 \mathrm{Md}$. & $\begin{array}{l}4 \text { Ireland } \\
3 \text { Canada }\end{array}$ \\
\hline 1875 & $\begin{array}{l}\text { Catholic Young } \\
\text { Men's Club }\end{array}$ & $\begin{array}{l}2 \text { Clerks } \\
\text { Clergy } \\
\text { Builder } \\
\text { Painter } \\
\text { Fish Dealer } \\
\text { Grocer } \\
\text { Seaman } \\
\end{array}$ & 9 & & \\
\hline 1875 & $\begin{array}{l}\text { Charitable Irish } \\
\text { Society }\end{array}$ & $\begin{array}{l}2 \text { Grocers } \\
\text { Business } \\
\text { owner } \\
\text { Sailor } \\
\text { Butcher }\end{array}$ & 8 & & \\
\hline 1880 & $\begin{array}{l}\text { Charitable Irish } \\
\text { Society }\end{array}$ & $\begin{array}{l}2 \text { Grocers } \\
\text { Merchant } \\
\text { Farmer } \\
\text { Police Officer }\end{array}$ & 9 & $\begin{array}{l}4 \mathrm{Md} . \\
2 \mathrm{Unm} .\end{array}$ & 5 Ireland \\
\hline 1880 & $\begin{array}{l}\text { St Patrick's Total } \\
\text { Abstinence and } \\
\text { Benevolent } \\
\text { Society }\end{array}$ & $\begin{array}{l}2 \text { Clerks } \\
2 \text { Coopers } \\
\text { Clergy } \\
\text { Fisherman } \\
\text { Wheelman } \\
\text { Shoemaker }\end{array}$ & 8 & $\begin{array}{l}2 \mathrm{Md} . \\
1 \mathrm{Unm} .\end{array}$ & $\begin{array}{l}2 \text { Ireland } \\
2 \text { Canada }\end{array}$ \\
\hline 1880 & Catholic Young & 2 Painters & 6 & $1 \mathrm{Md}$. & 2 Canada \\
\hline
\end{tabular}

Lovell's Province of Nova Scotia Directory for 1871, (Montreal: John Lovell, 1871); McAlpine's Halifax City Directory for 1875-1876, (Halifax: D. McAlpine \& Co., 1875); McAlpine's Halifax City Directory for 1880-1881, (Halifax: David McAlpine, 1881). 


\begin{tabular}{|l|l|l|l|l|}
\hline Men's Total & Jeweller & & 1 Wid. & 1 Ireland \\
Abstinence & Bookkeeper \\
Society & $\begin{array}{l}\text { Harness- } \\
\text { Maker }\end{array}$ & & & \\
\hline
\end{tabular}




\section{$\underline{\text { Appendix G }}$}

Officers of Irish Catholic Voluntary Associations in Quebec City, $1871^{1}$

\begin{tabular}{|c|c|c|c|c|c|}
\hline Year & Associations & Occupation & Officers Listed & Family Status & Birthplace \\
\hline 1871 & $\begin{array}{l}\text { Quebec } \\
\text { Hibernian } \\
\text { Benevolent } \\
\text { Society }\end{array}$ & $\begin{array}{l}2 \text { Clergy } \\
\text { Advocate } \\
\text { Stevedore } \\
\text { Merchant } \\
\text { School-Master } \\
\text { Labourer }\end{array}$ & 9 & $5 \mathrm{Md}$. & $\begin{array}{l}5 \text { Ireland } \\
2 \text { Canada }\end{array}$ \\
\hline 1871 & $\begin{array}{l}\text { St Bridget's } \\
\text { Asylum } \\
\text { Association }\end{array}$ & $\begin{array}{l}2 \text { Merchants } \\
2 \text { Clergy } \\
\text { City Councillor } \\
\text { Assessor } \\
\text { Clerk } \\
\text { Advocate } \\
\text { Politician } \\
\text { Accountant } \\
\text { Grocer } \\
\text { Cutler }\end{array}$ & 19 & $\begin{array}{l}6 \mathrm{Md} . \\
1 \mathrm{Unm} .\end{array}$ & $\begin{array}{l}6 \text { Ireland } \\
2 \text { Canada }\end{array}$ \\
\hline 1871 & $\begin{array}{l}\text { St Patrick's } \\
\text { Catholic and } \\
\text { Literary } \\
\text { Institute }\end{array}$ & $\begin{array}{l}\text { Clergy } \\
\text { Politician } \\
\text { Clerk } \\
\text { Beef Inspector } \\
\text { Ship Chandler }\end{array}$ & 9 & $\begin{array}{l}\text { I Md. } \\
1 \text { Wid. }\end{array}$ & 2 Ireland \\
\hline 1871 & $\begin{array}{l}\text { St Patrick's } \\
\text { Society }\end{array}$ & $\begin{array}{l}\text { Sheriff } \\
\text { Doctor } \\
\text { Merchant } \\
\text { Advocate }\end{array}$ & 7 & $4 \mathrm{Md}$. & 3 Ireland \\
\hline
\end{tabular}

1 Lovells' Province of Quebec Directory for 1871, (Montreal: John Lovell, 1871). 


\section{$\underline{\text { Appendix H }}$}

Officers of Irish Catholic Voluntary Associations in Hamilton, 1869-1876. ${ }^{1}$

\begin{tabular}{|l|l|l|l|l|l|}
\hline Year & Associations & Officers Listed & Occupation & $\begin{array}{l}\text { Family } \\
\text { Status }\end{array}$ & Birthplace \\
\hline 1869 & $\begin{array}{l}\text { St Patrick's } \\
\text { Society }\end{array}$ & 21 & $\begin{array}{l}\text { 2 Hotel-Keepers } \\
\text { Shoemaker } \\
\text { Labourer } \\
\text { Tailor } \\
\text { Merchant } \\
\text { Printer }\end{array}$ & $\begin{array}{l}\text { 5 Md. } \\
1 \text { Canada }\end{array}$ \\
\hline 1871 & $\begin{array}{l}\text { St Patrick's } \\
\text { Society }\end{array}$ & 6 & $\begin{array}{l}\text { 2 Shoemakers } \\
\text { Clerk }\end{array}$ & 2 Md. \\
1 Unm.. & 2 Ireland \\
1 Canada
\end{tabular}

1 Hamilton City Directory, 1869. North York Central Library, 917.1352 HAM Reel 3; Lovell's Province of Ontario Directory for 1871, (Montreal: John Lovell, 1871); Hamilton City Directory, 1875-76. North York Central Library, 917.1352 HAM Reel 3. 


\section{Appendix I}

Officers of Irish Catholic Temperance Societies in Montreal, $1845-1880 .{ }^{1}$

\begin{tabular}{|c|c|c|c|c|}
\hline Year & Association & $\begin{array}{l}\text { Occupation of Committee } \\
\text { Members }\end{array}$ & Family Status & Birthplace \\
\hline $1845-6$ & $\begin{array}{l}\text { Irish Catholic } \\
\text { Temperance Society }\end{array}$ & $\begin{array}{l}3 \text { Clergy } \\
2 \text { Civil Service } \\
2 \text { Merchants } \\
\text { Blacksmith }\end{array}$ & & \\
\hline 1850 & $\begin{array}{l}\text { St Patrick's Total } \\
\text { Abstinence Society }\end{array}$ & $\begin{array}{l}2 \text { Clergy } \\
\text { Merchant }\end{array}$ & $1 \mathrm{Md}$. & 2 Ireland \\
\hline 1860 & $\begin{array}{l}\text { St Patrick's Total } \\
\text { Abstinence Society }\end{array}$ & $\begin{array}{l}\text { Clergy } \\
\text { 4 Merchants } \\
\text { Civil Service } \\
\text { Brick-layer } \\
\text { Bookkeeper } \\
\text { Plumber and Gas-fitter }\end{array}$ & $\begin{array}{l}4 \mathrm{Md} . \\
2 \mathrm{Unm} .\end{array}$ & 6 Ireland \\
\hline 1865 & $\begin{array}{l}\text { St Patrick's Total } \\
\text { Abstinence Society }\end{array}$ & $\begin{array}{l}\text { Clergy } \\
7 \text { Merchants } \\
\text { Collector } \\
\text { Tanner } \\
\text { Cabinet-Maker } \\
\text { Cooper } \\
\text { Dyer } \\
\text { Carpenter } \\
\text { Boiler-Maker } \\
\text { Painter } \\
\text { Broom-maker }\end{array}$ & & \\
\hline 1870 & $\begin{array}{l}\text { St Ann's } \\
\text { Temperance Society }\end{array}$ & $\begin{array}{l}\text { Clergy } \\
\text { No Occupation } \\
\text { Contractor }\end{array}$ & $2 \mathrm{Md}$. & 3 Ireland \\
\hline & $\begin{array}{l}\text { St Bridget's Total } \\
\text { Abstinence Society }\end{array}$ & $\begin{array}{l}\text { Clergy } \\
3 \text { Merchants } \\
\text { Manufacturer }\end{array}$ & $\begin{array}{l}5 \mathrm{Md} . \\
2 \mathrm{Unm} .\end{array}$ & $\begin{array}{l}5 \text { Ireland } \\
1 \text { France } \\
\text { I Canada }\end{array}$ \\
\hline
\end{tabular}

1 The Montreal Directory for 1842-3, (Montreal: Lovell \& Gibson, 1843); The Montreal Directory, Corrected in May, 1850. (Montreal: Lovell and Gibson, 1850); The Montreal Directory, New Edition, Corrected in May and June 1855. (Montreal: Owler \& Stevenson, 1855); MacKay's Montreal Directory, New Edition, Corrected in May and June, 1860-61, (Montreal: Owler \& Stevenson, 1861); MacKay's Montreal Directory for 1865-6, (Montreal: John Lovell, 1866); Montreal Directory for 1870-1871, (Montreal: John Lovell, 1870); Lovell's Montreal Directory for 1875-76, (Montreal: John Lovell, 1876); Lovell's Montreal Directory for 1880-81, (Montreal: John Lovell \& Son, 1881). 


\begin{tabular}{|c|c|c|c|c|}
\hline & & $\begin{array}{l}\text { Crockery } \\
\text { Police }\end{array}$ & & \\
\hline & $\begin{array}{l}\text { St Patrick's Total } \\
\text { Abstinence Society }\end{array}$ & $\begin{array}{l}\text { Clergy } \\
6 \text { Merchants } \\
\text { Gas and Steam-fitter } \\
\text { Architect } \\
\text { Detective } \\
\text { Blacksmith } \\
\text { Notary } \\
\text { Engineer } \\
\text { Boilermaker } \\
\text { Cabinet-Maker } \\
\text { Military } \\
\text { Civil Service } \\
\text { Labourer } \\
\text { Trunkmaker }\end{array}$ & $\begin{array}{l}13 \mathrm{Md} . \\
1 \mathrm{Unm} .\end{array}$ & $\begin{array}{l}14 \text { Ireland } \\
1 \text { Canada }\end{array}$ \\
\hline 1875 & $\begin{array}{l}\text { St Bridget's Total } \\
\text { Abstinence and } \\
\text { Benefit Society }\end{array}$ & $\begin{array}{l}\text { Clergy } \\
\text { Carter } \\
\text { Machinist } \\
\text { Printer } \\
\text { Day Labourer }\end{array}$ & & \\
\hline & $\begin{array}{l}\text { St. Patrick's Total } \\
\text { Abstinence and } \\
\text { Benefit Society }\end{array}$ & $\begin{array}{l}\text { Clergy } \\
6 \text { Merchants } \\
2 \text { Labourers } \\
2 \text { Clerks } \\
\text { Carpenter } \\
\text { Printer } \\
\text { Cabinet-Maker } \\
\text { Notary } \\
\text { Teacher } \\
\text { Police } \\
\text { Foreman } \\
\text { Military } \\
\text { Carpenter } \\
\text { Pipemaker } \\
\text { Engineer }\end{array}$ & & \\
\hline 1880 & $\begin{array}{l}\text { St Ann's Total } \\
\text { Abstinence and } \\
\text { Benefit Society }\end{array}$ & $\begin{array}{l}\text { Clergy } \\
\text { 2 Labourers } \\
\text { Engineer } \\
\text { Printer } \\
\text { Shoemaker } \\
\text { Blacksmith } \\
\text { Contractor } \\
\text { Watchmaker } \\
\text { Leather-cutter }\end{array}$ & $\begin{array}{l}10 \mathrm{Md} . \\
1 \mathrm{Wid} .\end{array}$ & 7 Ireland \\
\hline
\end{tabular}




\begin{tabular}{|c|c|c|c|}
\hline & Foreman & & \\
\hline $\begin{array}{l}\text { St Bridget's Total } \\
\text { Abstinence and } \\
\text { Benefit Society }\end{array}$ & $\begin{array}{l}\text { Clergy } \\
2 \text { Merchants } \\
\text { Real Estate and } \\
\text { Collection Agent } \\
\text { Labourer }\end{array}$ & $\begin{array}{l}\text { Md. } \\
\text { Unm. } \\
\text { Wid. }\end{array}$ & $\begin{array}{l}3 \text { Ireland } \\
1 \text { United } \\
\text { States }\end{array}$ \\
\hline $\begin{array}{l}\text { St Gabriel's Total } \\
\text { Abstinence and } \\
\text { Benefit Society }\end{array}$ & $\begin{array}{l}\text { Clergy } \\
3 \text { Labourers } \\
\text { Machinist } \\
\text { Boilermaker } \\
\text { Clerk } \\
\text { Contractor }\end{array}$ & $\begin{array}{l}4 \mathrm{Md} . \\
3 \mathrm{Unm} .\end{array}$ & $\begin{array}{l}5 \text { Ireland } \\
1 \text { Canada }\end{array}$ \\
\hline $\begin{array}{l}\text { St Patrick's Total } \\
\text { Abstinence Society }\end{array}$ & $\begin{array}{l}\text { Clergy } \\
4 \text { Merchants } \\
3 \text { Labourers } \\
\text { Engineer } \\
\text { Clerk } \\
\text { Pipemaker } \\
\text { Notary } \\
\text { Mason } \\
\text { Coachman } \\
\text { Carpenter }\end{array}$ & $\begin{array}{l}9 \text { Md. } \\
3 \text { Unm. } \\
2 \text { Wid. }\end{array}$ & $\begin{array}{l}16 \text { Ireland } \\
1 \text { Canada }\end{array}$ \\
\hline
\end{tabular}




\section{Appendix J}

Officers of Irish Catholic Temperance Societies in Ottawa, 1864-1880. ${ }^{1}$

\begin{tabular}{|c|c|c|c|c|}
\hline Year & Association & $\begin{array}{l}\text { Occupation of } \\
\text { Committee Members }\end{array}$ & Family Status & Birthplace \\
\hline $1864-5$ & $\begin{array}{l}\text { Irish Catholic } \\
\text { Temperance } \\
\text { Society }\end{array}$ & $\begin{array}{l}\text { Clergy } \\
2 \text { Merchants }\end{array}$ & & \\
\hline $1870-1871$ & $\begin{array}{l}\text { Irish Catholic } \\
\text { Temperance } \\
\text { Society }\end{array}$ & Clergy & $3 \mathrm{Md}$. & 4 Ireland \\
\hline $1874-75$ & $\begin{array}{l}\text { Irish Catholic } \\
\text { Temperance } \\
\text { Society }\end{array}$ & $\begin{array}{l}\text { Clergy } \\
2 \text { Merchants } \\
2 \text { Teachers }\end{array}$ & & \\
\hline 1880 & $\begin{array}{l}\text { Irish Catholic } \\
\text { Temperance } \\
\text { Society }\end{array}$ & $\begin{array}{l}\text { Clergy } \\
3 \text { Labourers } \\
3 \text { Civil Service }\end{array}$ & $\begin{array}{l}7 \mathrm{Md} . \\
1 \mathrm{Unm} . \\
1 \text { Wid. }\end{array}$ & $\begin{array}{l}5 \text { Ireland } \\
3 \text { Canada }\end{array}$ \\
\hline
\end{tabular}

1 Mitchell \& Co.'s Carleton and Ottawa Directory 1864-5, (Ottawa: W.C. Chewett \& Co., 1865); Lovell's Province of Ontario Directory for 1871, (Montreal: John Lovell, 1871); Ottawa Directory for 1874-75, (Ottawa: A.S. Woodburn, 1875); The Ottawa Street, Alphabetical, Classified Business and Miscellaneous Directory for 1881, (Ottawa: A.S. Woodburn, 1881). 


\section{Appendix K}

Officers of Irish Catholic Temperance Societies in Halifax. 1871-1880. ${ }^{1}$

\begin{tabular}{|c|c|c|c|c|}
\hline Year & Association & $\begin{array}{l}\text { Occupation of Committee } \\
\text { Members }\end{array}$ & Family Status & Birthplace \\
\hline 1871 & $\begin{array}{l}\text { Halifax Catholic } \\
\text { Total Abstinence } \\
\text { and Benefit } \\
\text { Society }\end{array}$ & $\begin{array}{l}\text { Clergy } \\
3 \text { Labourers } \\
\text { Clerk } \\
\text { Seaman } \\
\text { Baker } \\
\text { Police } \\
\text { Coachman }\end{array}$ & $6 \mathrm{Md}$. & $\begin{array}{l}4 \text { Ireland } \\
3 \text { Canada }\end{array}$ \\
\hline \multirow[t]{2}{*}{1880} & $\begin{array}{l}\text { St Patrick's Total } \\
\text { Abstinence and } \\
\text { Benefit Society }\end{array}$ & $\begin{array}{l}\text { Clergy } \\
2 \text { Coopers } \\
2 \text { Clerks } \\
\text { Fisherman } \\
\text { Shoemaker }\end{array}$ & $\begin{array}{l}2 \mathrm{Md} . \\
1 \mathrm{Unm} .\end{array}$ & $\begin{array}{l}2 \text { Ireland } \\
2 \text { Canada }\end{array}$ \\
\hline & $\begin{array}{l}\text { Catholic Young } \\
\text { Men's Total } \\
\text { Abstinence and } \\
\text { Benefit Society }\end{array}$ & $\begin{array}{l}2 \text { Painters } \\
\text { Jeweller } \\
\text { Bookkeeper } \\
\text { Harness-Maker }\end{array}$ & $\begin{array}{l}1 \mathrm{Md} . \\
1 \mathrm{Wid} .\end{array}$ & $\begin{array}{l}2 \text { Canada } \\
1 \text { Ireland }\end{array}$ \\
\hline
\end{tabular}

Lovell's Province of Nova Scotia Directory for 1871, (Montreal: John Lovell, 1871); McAlpine's Halifax City Directory for 1875-1876, (Halifax: D. McAlpine \& Co., 1875); McAlpine's Halifax City Directory for 1880-1881, (Halifax: David McAlpine, 1881). 


\section{BIBLIOGRAPHY}

\section{PRIMARY SOURCES}

Archives of the Archdiocese of Halifax-Yarmouth.

002-18. St. Mary's Cathedral fonds. St. Mary's and St. Patrick's Temperance Society Series, Roll Book, 1843.

Archives de la Chancellerie de l' Archevêché de Montréal (ACAM):

355.121. Paroisse St Patrick.

1842-3. 790.021. Temperance.

1881-1913. 790.027. Catholic Total Abstinence Union.

Archives of Concordia University (ACU):

HA 219. Proceedings of St. Patrick's Total Abstinence and Benefit Society, 1868-71.

HA 219. Minutes of St Patrick's Total Abstinence and Benefit Society, 1879-1889.

$\underline{\text { Archives of Ontario }}$

F 1074. Charles James Foy Fonds.

F 485. Jessup Family Fonds.

RG 8-23 Correspondence of the Provincial Secretary's Office for Canada West.

Archives of the Roman Catholic Archdiocese of Toronto

Alexander Macdonell Fonds.

John Joseph Lynch Fonds.

Library and Archives Canada

MG 27 I E16. Darby Bergin Fonds. 
MG 24 I1 $07 . \quad$ Daniel O'Connor Fonds.

MG 27 IE 10A. Edward Murphy Fonds.

MG 26 A. John A. Macdonald Fonds.

MG 29 D15. James George Moylan Fonds

MG 30 C176. James F. Kenney Fonds

MG 27 I D5. John Costigan Fonds.

MG 29 B11. John Lawrence Power O'Hanly Fonds.

MG 27 I D13. John O'Connor Fonds.

MG 27 I E12. John O'Donohoe Fonds.

MG 24 D2. James John Hayes and Family Fonds.

MG 24 I $15 . \quad$ John Heney Fonds.

Census of Canada East, 1842 (online).

http://www.bac-lac.gc.ca/eng/census/1842-Canada-East/Pages/about-census.aspx. Last accessed 16 September 2015.

Census of Canada West, 1842 (online).

http://www.bac-lac.gc.ca/eng/census/1842-canada-west/Pages/about-census.aspx.

Last accessed 16 September 2015.

Census of 1851 (online).

http://www.bac-lac.gc.ca/eng/census/1851/Pages/about-census.aspx. Last accessed 16 September 2015.

Census of 1861 (online).

http://www.bac-lac.gc.ca/eng/census/1861/Pages/about-census.aspx. Last accessed 16 September 2015.

Census of 1871 (online).

http://www.bac-lac.gc.ca/eng/census/1871/Pages/about-census.aspx. Last accessed 16 September 2015.

Census of 1881 (online).

http://www.bac-lac.gc.ca/eng/census/1881/Pages/about-census.aspx. Last accessed 16 September 2015. 
Census of 1891 (online).

http://www.bac-lac.gc.ca/eng/census/1891/Pages/about-census.aspx. Last accessed 16 September 2015.

McCord Museum of Canadian History

M930-50-1-580. Seal of The St. Patrick's Total Abstinence Society.

Provincial Archives of Newfoundland and Labrador (PANL):

MG 612. Benevolent Irish Society Fonds.

\section{$\underline{\text { Published Primary Sources }}$}

A Brief Account of the Society of the Sons of St Patrick; with Biographical Notices of Some of the Members and Extracts from the Minutes. Philadelphia: Hibernian Society, 1843.

A Memoir of the Very Rev. Theobald Mathew, edited by P.H. Morris. New York: Alexander V. Blake, 1841.

Cashman, D.B. The Life of Michael Davitt with a History of the Rise and Development of the Irish National Land League. Boston: Murphy \& McCarthy Publishers, 1881.

Cochrane, Rev. William. The Canadian Album. Men of Canada; or Success by Example in Religion, Patriotism, Business, Law, Medicine, Education and Agriculture, Vol. 1. Bradley, Garreston \& Co.: Brantford, Ontario, 1891.

Cochrane, Rev. William. The Canadian Album. Men of Canada; or Success by Example in Religion, Patriotism, Business, Law, Medicine, Education and Agriculture, Vol. 2. Brantford, Ontario: Bradley, Garreston \& Co., 1893.

Cochrane, Rev. William. The Canadian Album. Men of Canada; or Success by Example in Religion, Patriotism, Business, Law, Medicine, Education and Agriculture, Vol. 3. Brantford, Ontario: Bradley, Garreston \& Co., 1894.

Cochrane, Rev. William. The Canadian Album. Men of Canada; or Success by Example in Religion, Patriotism, Business, Law, Medicine, Education and Agriculture, Vol. 4. Brantford, Ontario: Bradley, Garreston \& Co., 1895.

Cologan, Rev. W.H. and Sir Francis Richard Cruise. The Catholic Temperance Reader. London: Catholic Truth Society, 1900.

Davin, Nicholas Flood. The Irishman in Canada. London: Sampson Low, Marston \& Co.; Toronto: Maclear and Company, 1877.

Gibbs, Joseph C. History of the Catholic Total Abstinence Union of America. Philadelphia: 
Penn Printing House, 1907.

Golden Jubilee of the Reverend Fathers Dowd and Toupin, with Historical Sketch of Irish Community of Montreal, edited by J.J. Curran. Montreal: John Lovell and Son, 1887.

Hopkins, J. Castell. The Canadian Album: Encyclopedic Canada, or The Progress of a Nation in Religion, Patriotism, Business, Law, Medicine, Eeducation and Agriculture, Vol. V. Brantford, Ontario: The Bradley-Garreston Company Ltd, 1896.

Letters of John O'Connor, Esq., M.P., on Fenianism: addressed to His Excellency the Right Honourable John Young, Bart., P.C., G.C.B., G.C.MG., governor-feneral of Canada, etc., etc., etc. Toronto: Hunter, Rose, 1870.

McCourt, Peter. Biographical Sketch of the Honorable Edward Whelan, Together with a Compilation of his Principal Speeches. Charlottetown, 1888.

Northgraves, George. The Mistake of Modern Infidels, or, Evidences of Christianity: Comprising a complete refutation of Colonel Ingersoll's so-called Mistakes of Moses, and objections of Voltaire, Paine, and others against Christianity. Detroit: Free House Printing Press, 1885.

O'Hanly, John Lawrence Power. The Political Standing of Irish Catholics in Canada: A Critical Analysis of its Causes, with Suggestions for its Amelioration. Ottawa: 1872.

O'Leary, Peter. Travels and Experiences in Canada, The Red River Territory, and the United States. London: John B. Day Printer and Publisher, 1877.

P.P.A. In Ontario: History and Principles of the Organization. 1894 (online). https://archive.org/details/cihm_25285. Last accessed 16 September 2015.

Proceedings of the Home Rule Conference Held at The Rotunda, Dublin on The $18^{\text {th }}, 19^{\text {th }}$, $20^{\text {th }}$ and $21^{\text {st }}$ November, 1873. Dublin: The Irish Home Rule League, 1874

Rose, George MacLean. A Cyclopaedia of Canadian Biography: Being Chiefly Men of the Time, Vol. 1. Toronto: Rose Publishing Company, 1886.

Rose, George MacLean. A Cyclopaedia of Canadian Biography: Being Chiefly Men of the Time, Vol. 2. Toronto: Rose Publishing Company, 1888.

Speech of the Hon. Frank Smith, delivered in the Senate of Canada, April 1885, on a resolution relating to Canada Temperance Act and Liquor License Act Amendment Bill (online). https://archive.org/details/cihm_01476. Last accessed 16 September 2015.

Speeches Delivered by Hon. Edward Blake, the leader of the Liberal Party and a Synopsis of the Debate on the Home Rule Resolutions in the House of Commons. Toronto: C. Blackett Robinson, 1886. 
Souvenir of the Golden Jubilee of St. Patrick's T.A.\&B Society, 1840-1890. Montreal:

Dominion Illustrated Co., 1890.

Temperance Lectures Delivered in St. Patrick's and St. Ann's Churches: A Grateful Tribute to Father Mathew's Memory and Work, 1890 (online).

https://archive.org/details/cihm_25578. Last accessed 16 September 2015.

The Canadian Biographical Dictionary and Portrait Gallery of Eminent and Self-Made Men, Ontario Volume. Chicago, New York, and Toronto: American Biographical Publishing Company, 1880.

The Canadian Biographical Dictionary and Portrait Gallery of Eminent and Self-Made Men, Quebec and Maritime Provinces Volume. Chicago, New York, and Toronto: American Biographical Publishing Company, 1881.

The Metropolitan Catholic Almanac and Laity's Directory. Baltimore: John Murphy \& Co., 1860 .

The Riel and Home Rule Questions: Hon. John Costigan's Speech at Woodstock, N.B., Mr. Costigan's Letter to Lord Lorne on Home Rule for Ireland, Gladstone's Bill Foreshadowed, Opinions of the Irish National Newspapers. Messrs. Curran, Coughlin, \& C., 1887.

\section{Published Voluntary Association Material}

Constitution of the St Patrick's Society of Quebec, 1836 (online).

https://archive.org/details/cihm_47545. Last accessed 16 September 2015.

The Constitution and By-laws of the Irish Catholic Benevolent Society of Quebec, 1873 (online). https://archive.org/details/cihm_57777. Last accessed 16 September 2015.

The Constitution and By-laws of the Charitable Irish Society of Boston, 1882 (online). https://archive.org/details/constitutionbyla00char. Last accessed 16 September 2015.

The Rules and Constitution of the Charitable Irish Society Established at Halifax in the Province of Nova Scotia, 1795. Halifax: Howe and M'Kinstry, 1795.

Constitution and Rules of the Father Mathew Association organized at St. John, New Brunswick, 9 March 1871, revised September, 1892 (online).

https://archive.org/details/cihm_98690. Last accessed 16 September 2015.

St. Mary's Total Abstinence Society of Halifax founded by the Very Reverend John Loughnan, January 24 ${ }^{\text {th }}, 1841$. Canadian Institute of Historical Microreproductions, 64923.

Constitution and Bylaws of Halifax Catholic Total Abstinence and Benefit Society founded $2^{\text {nd }}$ Feb'y., 1857 by the Rev. John Higginbotham. Halifax: Compton and Bowden, 1858. 
Constitution and by-laws of the Irish Catholic Benevolent Society of Quebec: Adopted $24^{\text {th }}$ February, 1872; Revised and Amended 24 $4^{\text {th }}$ February, 1873. Quebec: Middleton and Dawson, 1873.

Constitution of the Catholic Total Abstinence Union of New Brunswick, Together with the Proceedings of the First Annual Convention of the Union, Held at Saint John, N.B. June 29 and 30, 1872. St. John: Geo. A. Knodell, 1872.

Provincial Archives of Nova Scotia, online exhibit on the Charitable Irish Society. https://novascotia.ca/archives/CIS/. Accessed 16 December 2015.

History of The Society of the Friendly Sons of St Patrick in the City of New York, (online) https://www.friendlysonsnyc.com/index.cfm?fl=history. Accessed 19 January 2016.

\section{$\underline{\text { Government Documents }}$}

Debates of the Senate of the Dominion of Canada, 1882. Ottawa: A.S. Woodburn, 1882.

Journals of the House of Commons of the Dominion of Canada, From the $4^{\text {th }}$ February to the $8^{\text {th }}$ April, 1875. Hunter Rose: Ottawa, 1875.

Journals of the House of Commons of the Dominion of Canada From the $7^{\text {th }}$ February to the $10^{\text {th }}$ May, 1878. MacLean, Roger: Ottawa, 1878.

Journals of the House of Commons of the Dominion of Canada, from the $13^{\text {th }}$ February to the $15^{\text {th }}$ May, 1879. MacLean, Roger: Ottawa, 1879.

Official Debates of the House of Commons of the Dominion of Canada: Fourth Session, Fourth Parliament. Edited by John Chas. Boyce. Ottawa: MacLean, Roger \& Company, 1882.

Official Report of the Debates of the House of Commons of the Dominion of Canada. First Session-Sixth Parliament, Vol. XXIV, 13 May-23 June 1887. MacLean, Roger, \& Co.:

Ottawa, 1887.

Local Self Government for Ireland, Speech Delivered by Mr John Costigan, M.P. In the House of Commons of Canada, Thursday April 20, 1882. Online, https://archive.org/stream/cihm_04179\#page/n9/mode/2up. Last accessed 31 March 2016.

\section{$\underline{\text { Newspapers }}$}

Belleville Intelligencer (Belleville)

The Sacred Heart Review (Boston) 
The Cross (Halifax)

London Catholic Record (London)

True Witness and Catholic Chronicle (Montreal)

The Harp (Montreal)

The Gazette (Montreal)

Montreal Daily Star (Montreal)

Montreal Pilot (Montreal)

Ottawa Citizen (Ottawa)

Ottawa Tribune (Ottawa)

New York Herald (New York)

New York Times (New York)

Canadian Freeman (Toronto)

Catholic Register (Toronto)

Evening Times (Toronto)

Irish Canadian (Toronto)

The Globe (Toronto)

The Sentinel and Orange and Protestant Advocate (Toronto)

Toronto Mirror (Toronto)

\section{$\underline{\text { Provincial Directories }}$}

Ontario

Lovell's Province of Ontario Directory for 1871. Montreal: John Lovell, 1871.

Quebec

Lovells' Province of Quebec Directory for 1871. Montreal: John Lovell, 1871.

Nova Scotia

Lovell's Province of Nova Scotia Directory for 1871. Montreal: John Lovell, 1871. 


\section{City Directories}

Montreal

The Montreal Directory for 1842-3. Montreal: Lovell \& Gibson, 1843.

The Montreal Directory, Corrected in May, 1850. Montreal: Lovell and Gibson, 1850.

The Montreal Directory, New Edition, Corrected in May and June 1855. Montreal: Owler \& Stevenson, 1855.

MacKay's Montreal Directory, New Edition, Corrected in May and June, 1860-61. Montreal: Owler \& Stevenson, 1861.

MacKay's Montreal Directory for 1865-6. Montreal: John Lovell, 1866.

Montreal Directory for 1870-1871. Montreal: John Lovell, 1870.

Lovell's Montreal Directory for 1875-76. Montreal: John Lovell, 1876.

Lovell's Montreal Directory for 1880-81. Montreal: John Lovell \& Son, 1881.

Ottawa

Mitchell \& Co.'s Carleton and Ottawa Directory 1864-5. Ottawa: W.C. Chewett \& Co., 1865.

Sutherland's City of Ottawa Directory for 1868. Ottawa: Hunter, Rose \& Company, 1868.

Ottawa Directory for 1874-75. Ottawa: A.S. Woodburn, 1875.

The Ottawa Street, Alphabetical, Classified Business and Miscellaneous Directory for 1881. Ottawa: A.S. Woodburn, 1881.

\section{Toronto}

Toronto Directory and Street Guide for 1843-44. Toronto: H. \& W. Rowsell, 1844.

Brown's Toronto City and Home District Directory. Toronto: George Brown, 1846.

Rowsell's City of Toronto and County of York Directory 1850. Toronto: Henry Rowsell, 1850.

Caverhill's Toronto City Directory 1859. Toronto: W.C.F. Caverhill, 1859.

Brown's Toronto General Directory 1861. Toronto: W.C. Chewett, 1861. 
Mitchell \& Co.'s General Directory for the City of Toronto, and Gazetteer of the Counties of York and Peel for 1866. Toronto: Mitchell \& Co., 1866.

Toronto Directory for 1877. Toronto: Might \& Taylor, 1877.

Halifax

McAlpine's Halifax City Directory for 1875-1876. Halifax: D. McAlpine \& Co., 1875.

McAlpine's Halifax City Directory for 1880-1881. Halifax: David McAlpine, 1881.

Hamilton

Hutchinson's Hamilton City Directory 1862-3. Hamilton: Eastwood, 1863.

Hamilton City Directory, 1869. North York Central Library, 917.1352 HAM Reel 3.

Hamilton City Directory, 1875-76. North York Central Library, 917.1352 HAM Reel 3.

Kingston

A Directory of the City of Kingston 1855. Kingston: John Duff, 1855.

\section{SECONDARY SOURCES}

Adas, Michael. Machines As the Measure of Men: Science, Technology, and Ideologies of Western Dominance. New York: Cornell University Press, 1989.

Akenson, Donald. “Ontario: Whatever Happened to the Irish?" In Canadian Papers in Rural History, Volume III, edited by Donald Akenson, 204-256. Gananoque: Langdale Press, 1982.

_ _ - . The Irish in Ontario: A Study in Rural History. Kingston and Montreal: McGillQueen's University Press, 1984.

_ — - The Irish Diaspora: A Primer. Toronto: P.D. Meany Company Inc. Publishers, 1993.

Alba, Richard. “Assimilation’s Quiet Tide.” The Public Interest 119 (1995): 1-18.

Alba, Richard and Victor Nee. "Rethinking Assimilation Theory for a New Era of Immigration." International Migration Review 31.4 (Winter 1997): 826-874.

Alexander, Ruth. "We are Engaged as a Band of Sisters': Class and Domesticity in the Washingtonian Temperance Movement, 1840-1850," Journal of American History, 75, no.3 
(December 1988): 763-785.

Anbinder, Tyler. Five Points: The $19^{\text {th }}$ Century New York City Neighbourhood That Invented Tap Dance, Stole Elections, and Became the World's Most Notorious Slum. New York and London: The Free Press, 2001.

Anderson, Benedict. Imagined Communities: Reflections on the Origin and Spread of Nationalism. London and New York: Verso, 1983. Revised edition 2006.

Anderson, Robert T. "Voluntary Associations in History," American Anthropologist LXXIII (February 1971): 209-222.

Anstead, Christopher J. "Hegemony and Failure: Orange Lodges, Temperance Lodges, and Respectability in Victorian Ontario." In The Changing Face of Drink: Substance, Imagery, and Behaviour, edited by Jack S. Blocker and Cheryl Krasnick Warsh, 163-188. Ottawa: Les publications Histoire Sociale, 1997.

Archer, Melanie and Judith R. Blau. "Class Formation in Nineteenth-Century America: The Case of the Middle-Class.” Annual Review of Sociology, 19 (1993): 17-41.

Babchuk, Nicholas and Ralph Thompson. "The Voluntary Associations of Negroes," American Sociological Review XXVII (October, 1962): 647-655.

Baker, William. Timothy Warren Anglin: 1822-1896 Irish Catholic Canadian. Toronto and Buffalo: University of Toronto Press, 1977.

Ballentyne, Tony. "Introduction: Debating Empire." Journal of Colonialism and Colonial History 3(1)(2002). Accessed September 14 2015. doi: 10.1353/cch.2002.0002.

Bannister, Jerry. The Rule of the Admirals: Law, Custom, and Naval Government in Newfoundland, 1699-1832. Toronto: University of Toronto Press, 2003.

_ _ _ . "Canada as Counter-Revolution: The Loyalist Order Framework in Canadian History, 1750-1840." In Liberalism and Hegemony: Debating the Canadian Liberal Revolution, edited by Jean-François Constant and Michel Ducharme, 98-146. Toronto: University of Toronto Press, 2009.

Barkan, R. Elliot. "Race, Religion, and Nationality in American Society: A Model of Ethnicity-from Contact to Assimilation." Journal of American Ethnic History 14 (1995): 38-101.

_ _ _ . "Immigration, Incorporation, Assimilation, and the Limits of Transnationalism." In Immigration, Incorporation and Transnationalism, edited by Elliott R. Barkan, 1-23. New Brunswick and London: Transaction Publishers, 2007.

Barr, Andrew. Drink: A Social History of America. New York: Carroll and Graf Publishers, 1999. 
Barr, Colin. "Imperium in Imperio": Irish Episcopal Imperialism in the Nineteenth Century," English Historical Review, CXXIII, 502 (June 2008): 611-650.

Barrett, James R. "Why Paddy Drank: The Social Importance of Whiskey in Pre-Famine Ireland." Journal of Popular Culture, 21.1 (Summer 1977): 155-166.

Barron, F.L. "Alcoholism, Indians, and the Anti-Drink Cause in the Protestant Indian Missions of Upper Canada, 1822-1850." In As Long as the Sun Shines and Water Flows: A Reader in Canadian Native Studies, edited by Ian L. Getty and Antoine S. Lussier, 191-202. Vancouver: UBC Press, 1983.

_ _ _ . "The American Origins of the Temperance Movement in Ontario, 1828-1850." Canadian Review of American Studies, 11.2 (Fall 1980): 131-150.

Barrows, Susanna, Robin Room and Jeffrey Verhey, eds. The Social History of Alcohol: Drinking and Culture in Modern Society. Berkley: Medical Research Institute of San Francisco, Alcohol Research Group 1987.

Barth, Frederic. Ethnic Groups and Boundaries: The Social Organization of Cultural Differences. Oslo: Universitetsforlaget, 1969.

Bateman, Fiona. "Ireland's Spiritual Empire: Territory and Landscape in Irish Catholic Missionary Discourse." In Empires of Religion edited by Hilary M. Carey, 267-287. London: Palgrave Macmillan, 2008.

Beck, J. Murray. Joseph Howe Volume II: The Briton Becomes Canadian, 1848-1873. Montreal and Kingston: McGill-Queen's University Press, 1984.

Beckingham, David. "The Irish Question and the Question of Drunkenness: Catholic Loyalty in Nineteenth Century Liverpool.” Irish Geography 42.2 (July 2009): 125-144.

Begnal, Calista. "Sisters of the Congregation of Notre Dame Nineteenth Century Kingston." CCHA Study Sessions, 40 (1973): 27-33.

Belchem, John. "The Immigrant Alternative: Ethnic and Sectarian Mutuality Among the Liverpool Irish During the Nineteenth Century." In The Duty of Discontent: Essays for Dorothy Thompson, edited by Owen Ashton, Robert Fyson and Stephen Roberts, 231-250. London; New York: Mansell, 1995.

_ _ _ _ "Priests, Publicans and the Irish Poor: Ethnic Enterprise and Migrant Networks in Mid-Nineteenth-Century Liverpool." Immigrants and Minorities 23.2-3 (2005): 207-231.

Bell, Duncan. The Idea of Greater Britain: Empire and the Future of World Order, 18601900. Princeton and Oxford: Oxford University Press, 2007.

Berelson, Bernard and Gary A. Steiner, Human Behaviour: An Inventory of Scientific 
Findings. New York: Harcourt, Brace, 1964.

Berger, Carl. The Sense of Power: Studies in the Ideas of Canadian Imperialism, 1867-1914. Toronto: University of Toronto Press, 1970.

Berlin, Isaiah. Four Essays on Liberty. Oxford: Oxford University Press, 1969.

Bew, Paul. Land and the National Question in Ireland, 1858-1882. Dublin: Gill and Macmillan, 1979.

Bledstein, Burton J. The Culture of Professionalism: The Middle-Class and the Development of Higher Education in America. New York: W.W. Norton and Co., 1976.

_ _ _ “Introduction." In The Middling Sorts: Explorations in the History of the American Middle-Class, edited by Burton J. Bledstein and Robert D. Johnston, 1-26. New York and London: Routledge, 2001.

Black, Naomi and Gail Cuthbert Brandt. "Alcohol and the First Women's Movement." Etudes canadiennes/Canadian Studies 35 (1993): 95-106.

Blainey, Anna. "The Prohibition and Total Abstinence Movement in Australia, 1880-1910," In Food, Power and Communities: Essays in the History of Food and Drink, ed. Robert Dare. Adelaide: Wakefield Press, 1999: 142-152.

Blank, Joshua. "Pitching, Pies and Piety: Early Twentieth Century St Hedwig's Parish Picnics." Historical Studies Volume 76 (2010): 61-86.

Bleasdale, Ruth. "Class Conflict on the Canals of Upper Canada in the 1840s." Labour/Le Travailleur 7 (1981): 9-39.

Blocker, Jack. “Give to the Winds Thy Fears:” The Women's Temperance Crusade, 18731874. Westport, Connecticut and London, England: Greenwood Press, 1985.

_ _ _ American Temperance Movements: Cycles of Reform. Boston: Twayne Publishers, 1989.

Blocker, Jack and Cheryl Krasnick-Warsh, eds. The Changing Face of Drink: Substance, Imagery, and Behaviour. Ottawa: Les publications Histoire Sociale, 1997.

Blocker, Jack S. David M. Fahey, Ian R. Tyrell, Alcohol and Temperance in Modern History: An International Encyclopedia. Santa Barbara: ABC-CLIO, 2003.

Blumin, Stuart M. "The Hypothesis of Middle-Class Formation in Nineteenth-Century America: A Critique and Some Proposals." The American Historical Review 90, no. 2 (April 1985): 299-338.

_ _ - The Emergence of the Middle-Class: Social Experience in the American City, 1760- 
1900. New York: Cambridge University Press, 1989.

Bodnar, John. The Transplanted: A History of Immigrants in Urban America. Bloomington: Indiana University Press, 1985.

Bonenfant, J.C. "DEVLIN, BERNARD.” In Dictionary of Canadian Biography, vol. 10, University of Toronto/Université Laval, 2003-, accessed April 7, 2016, http://www.biographi.ca/en/bio/devlin_bernard_10E.html.

Bordin, Ruth. Women and Temperance: The Quest for Power and Liberty, 1873-1900. Philadelphia: Temple University Press, 1981.

Boyce, George D. and Alan O'Day, ed., Gladstone and Ireland: Politics, Religion, and Nationality in the Victorian Age. Houndmills, Basingstoke, Hampshire; New York: Palgrave Macmillian, 2010.

Boyer, Paul. Urban Masses and Moral Order in America, 1820-1920. Cambridge: Harvard University Press, 1992.

Brasted, Howard. "Indian Nationalist Development and the Influence of Irish Home Rule, 1870-1886." Modern Asian Studies 14.1 (1980): 37-63.

Bretherton, George. "Against the Flowing Tide: Whiskey and Temperance in the Making of Modern Ireland." In The Social History of Alcohol: Drinking and Culture in Modern Society, edited by Susanna Barrows, Robin Room and Jeffrey Verhey, 147-164. Berkley: Medical Research Institute of San Francisco, Alcohol Research Group 1987.

_ _ _ “ "The Battle Between Carnival and Lent: Temperance and Repeal in Ireland, 18291845." HS/SH 27.54 (November 1994): 295-320.

Brown, J.B. "The Pig or the Stye: Drink and Poverty in Late Victorian England." International Review of Social History, 17 (1973): 380-395.

Brown, Stuart J. David W. Miller, eds, Piety and Power in Ireland, 1760-1960: Essays in Honour of Emmet Larkin. Belfast: Institute of Irish Studies and University of Notre Dame Press, 2000.

Brownlie, Robin Jarvis. "A Persistent Antagonism: First Nations and the Liberal Order." In Liberalism and Hegemony: Debating the Canadian Liberal Revolution, Jean-Francois Constant and Michel Ducharme, eds. 298-321. Toronto: University of Toronto Press, 2009.

Bridgen, Lorne. "On Their Own Terms: Temperance in Southern Ontario's Black Community, 1830-1860.” Ontario History 101, no. 1, (Spring 2009): 64-82.

Brighton, Stephen A. Historical Archaeology of the Irish Diaspora: A Transnational Approach. University of Tennessee Press: Knoxville, 2009. 
Brown, Thomas. Irish-American Nationalism, 1870-1890. Philadelphia and New York: J.B. Lippincott Company, 1966.

Brundage, David. "Recent Directions in the History of Irish American Nationalism." Journal of American Ethnic History 28.4 (2009): 82-89.

Buckner, Phillip and R. Douglas Francis. "Introduction," in Canada and the British World: Culture, Migration, and Identity edited by Phillip Buckner and R. Douglas Francis, 1-9. Vancouver: UBC Press, 2006.

Buckner, Phillip ed. Canada and the British Empire. Oxford: Oxford University Press, 2008.

Burrell, Kathy. "Time Matters: Temporal Contexts of Polish Transnationalism." In Transnational Ties: Cities, Migrations, and Identities, edited by Michael Peter Smith and John Eade, 15-38. New Brunswick and London: Transaction Publishers, 2008.

Burroughs, Robert. "Imperial Eyes or 'The Eyes of Another Race'? Roger Casement's Travels in West Africa.” Journal of Imperial and Commonwealth History 37.3 (2009): 383397.

Burton, Antoinette. "Déjà vu All Over Again." Journal of Colonialism and Colonial History. 3.1 (2002). Accessed September 14 2015. doi: 10.1353/cch.2002.0004.

Cain, Peter J. "Character, 'Ordered Liberty', and the Mission to Civilise: British Moral Justification of Empire, 1870-1914." Journal of Imperial and Commonwealth History, 40.4 (2012): 557-578

Campbell, Robert. "Managing the Marginal: Regulating and Negotiating Decency in Vancouver's Beer Parlours, 1925-1954.” L/LT 44 (Fall 1999): 172-192.

Careless, J.M.S. Brown of the Globe: Statesman of Confederation, 1860-1880. Toronto: The Macmillian Company of Canada, 1963.

Casey, Marion R. "Family, History, and Irish America." Journal of American Ethnic History 28.4 (2009): 110-117.

Cavell, Janice. "The Imperial Race and the Immigration Sieve: The Canadian Debate on Assisted British Migration and Empire Settlement, 1900-1930." Journal of Imperial and Commonwealth History 34.3 (2006): 345-367.

Chilton, Lisa. Agents of Empire: British Female Migration to Canada and Australia, 1860s1930. Vancouver: UBC Press, 2007.

Christie, Nancy. "Revisiting Canada's Project of Liberal Rule, The Underhill Review (Fall 2009).www3.carleton.ca/underhillreview/09/fall/reviews/christie.htm. Accessed 20 February 2014. 
Cisneros, Josue David. The Border Crossed Us: Rhetorics of Borders, Citizenship, and Latina/o Identity. Tuscaloosa: University of Alabama Press, 2013.

Clarke, Brian. "The Parish and the Hearth: Women's Confraternities and the Devotional Revolution Among the Irish Catholic's of Toronto, 1850-1895." In Creed and Culture: The Place of English-Speaking Catholics in Canadian Society, 1750-1930 edited by Terrence Murphy and Gerald Stortz, 185-203. Montreal and Kingston: McGill-Queen's University Press, 1993.

____Piety and Nationalism: Lay Voluntary Associations and the Creation of an IrishCatholic Community in Toronto, 1850-1895. Montreal and Kingston: McGill-Queen's University Press, 1993.

Clark, Samuel. Social Origins of the Irish Land War. Princeton: Princeton University Press, 2014.

Cohen, Robin. "Diasporas and the Nation-State: From Victims to Challengers."

International Affairs 72.3 (July 1996): 507-520.

Collard, Elizabeth. "MCGARVEY, OWEN," in Dictionary of Canadian Biography, vol. 12 University of Toronto/ Université Laval-, accessed January 6, 2014, http://www.biographi.ca/en/bio/mcgarvey_owen_12E.html.

Colley, Linda. Britons: Forging the Nation, 1707-1837. New Haven: Yale University Press, 1992.

Collombier-Lakeman, Pauline. "Ireland and Empire: The Ambivalence of Irish

Constitutional Nationalism.” Radical History Review 104 (Spring 2009): 57-76.

Comerford, R.V. The Fenians in Context: Irish Politics and Society, 1848-82. Dublin: Wolfhound Press, 1985.

Conley, Mary A. From Jack Tar to Union Jack: Representing Naval Manhood in the British Empire, 1870-1918. Manchester: Manchester University Press, 2009.

Connolly, John R. Henry Newman: A View of Catholic Faith for the New Millennium. Lanham, Maryland: Rowman and Littlefield Publishers, 2005.

Connolly, S.J. "Eighteenth-Century Ireland," in The Making of Modern Irish History: Revisionism and The Revisionist Controversy, edited by D. George Boyce and Alan O'Day. London and New York: Routledge, 1996, 15-33.

Conroy, David W. In Public Houses: Drink and the Revolution of Authority in Colonial Massachusetts. Chapel Hill: University of North Carolina Press, 1995.

Constant, Jean-Francois and Michel Ducharme eds., Liberalism and Hegemony: Debating the Canadian Liberal Revolution. Toronto: University of Toronto Press, 2009. 
Cook, S.B. "The Irish Raj: Social Origins and Careers of Irishmen in the Indian Civil Service, 1855-1914.” Journal of Social History 20 (1987): 514-522.

Cook, Ramsay. The Regenerators: Social Criticism in Late Victorian Canada. Toronto: University of Toronto Press, 1985.

Cooper, Fredrick and Ann Laura Stoler eds. Tensions of Empire: Colonial Cultures in a Bourgeois World. Berkeley and Los Angeles: University of California Press, 1997.

Corbally, John. "The Jarring Irish: Postwar Immigration to the Heart of Empire." Radical History Review 104 (Spring 2006): 103-125.

Corcoran, Brandon S. and Laura J. Smith. "Bishop Macdonell and The Friends of Ireland: Mixing Politics and Religion in Upper Canada," Historical Studies 79 (2013): 7-23.

Corrigan, Philip and Derek Sayer. The Great Arch: English State Formation as Cultural Revolution. Oxford: Basil Blackwell Inc., 1985.

Cottrell, Michael. "St. Patrick's Day Parades in Nineteenth Century Toronto: A Study of Immigrant Adjustment and Elite Control." Histoire sociale/Social History 25.49 (May 1992): 57-73.

- _ - "Green and Orange in Mid-Nineteenth-Century Toronto: The Guy Fawkes Day Episode of 1864." Canadian Journal of Irish Studies 19.1 (July 1993): 12-21.

_ _ _ “John O'Donohoe and the Politics of Ethnicity in Nineteenth-Century Ontario," CCHA, Historical Studies, 56 (1989): 67-84.

Cowan, Helen I. British Immigration Before Confederation. Canadian Historical Association Booklets, Canada's Ethnic Groups. Ottawa: Canadian Historical Association, 1978.

Cronin, Mike and Daryl Adair. The Wearing of the Green: A History of St. Patrick's Day. London and New York: Routledge, 2002.

Crooks, Katherine. "The Quest for Respectability: The Charitable Irish Society in Victorian Halifax." Canadian Catholic Historical Association, Historical Studies 81 (2015): 167-194.

Cross, Dorothy S. “The Irish in Montreal, 1867-1896.” (MA Thesis, McGill University, 1969).

Cruikshank, Julie. Do Glaciers Listen?: Local Knowledge, Colonial Encounters, and Social Imagination. Vancouver: UBC Press, 2005.

Cunich, Peter. "Archbishop Vaughan and the Empires of Religion in Colonial New South Wales.” In Empires of Religion, edited by Hilary M. Carey, 137-160. London: Palgrave 
Macmillan, 2008.

Curtis, Bruce. "Class Culture and Administration: Educational Inspection in Canada West." In Colonial Leviathan: State Formation in Mid-Nineteenth-Century Canada, edited by Allan Greer and Ian Radforth, 103-133. Toronto: University of Toronto Press, 1992.

_ _ _ “After 'Canada': Liberalisms, Social Theory, and Historical Analysis." In Liberalism and Hegemony: Debating the Canadian Liberal Revolution, edited by Jean-Francois Constant and Michel Ducharme, 176-200. Toronto: University of Toronto Press, 2009.

Curtis Jr., L. Perry. Anglo-Saxons and Celts: A Study of Anti-Irish Prejudice in Victorian England. University of Bridgeport, Conn.: Conference on British Studies, 1968.

_ — - Apes and Angels: The Irishman in Victorian Caricature. Washington: Smithsonian Institute Press, 1971.

Cuthbertson, B.C. "UNIACKE, RICHARD JOHN (1753-1830)," in Dictionary of Canadian Biography, vol. 6, University of Toronto/Université Laval, 2003-, accessed March 15, 2016,http://www.biographi.ca/en/bio/uniacke_richard_john_1753_1830_6E.ht

Darroch, Gordon and Michael Ornstein. "Ethnicity and Occupational Structure in Canada in 1871: The Vertical Mosaic in Historical Perspective." Canadian Historical Review 61 (Sept 1980): 305-333.

Darroch, Gordon. "Half Empty or Half Full? Images and Interpretations in the Historical Analysis of the Catholic Irish in Nineteenth-Century Canada." Canadian Ethnic Studies 25, no. 1, (1993): 1-8.

_ _ — "Domestic Revolution and Cultural Formation in Nineteenth-Century Ontario, Canada. The History of the Family 4, no. 4 (1999): 427-445.

Davidoff, Lenore and Catherine Hall. Family Fortunes: Men and Women of the English Middle Class, 1780-1850. Chicago: University of Chicago Press, 1987.

Dean, Joanna. Religious Experience and the New Woman: The Life of Lily Dougall. Bloomington: Indiana University Press, 2006.

Delottenville, Peter. "Joe Beef of Montreal: Working-Class Culture and the Tavern, 18691889.” Labour/Le Travailleur 8/9 (Autumn/Spring 1981-82): 9-40.

den Otter, A.A. The Philosophy of Railways: The Transcontinental Railway Idea in British North America. Toronto: University of Toronto Press.

Deslandres, Dominique, John A. Dickinson and Ollivier Hubert, eds., The Sulpicians of Montreal: A History of Power and Discretion, 1657-2007. Montreal: Wilson and Lefleur, 2007. 
Dictionary of Jesuit Biography: Ministry to English Canada, vol. 1: 1842-1987 (Canadian Institute of Jesuit Studies: Toronto, 1991)

Duffy, Eamon. "The Age of Pio Nono: The Age of Paul Cullen." In Cardinal Paul Cullen and his World, edited by Daire Keogh and Albert McDonnell. Dublin: Four Courts Press, 2011.

Eagleton, Terry. "Afterword: Ireland and Colonialism.” In Was Ireland a Colony? Economics, Politics and Culture in Nineteenth-Century Ireland, edited by Terrence McDonough, 326-333. Dublin: Irish Academic Press, 2005.

Eley, Geoff. "Beneath the Skin. Or: How to Forget about the Empire Without Really Trying." Journal of Colonialism and Colonial History. 3.1 (2002). Accessed September 15, 2015. doi: 10.1353/cch.2002.0008.

Elliott, Bruce. Irish Migrants in the Canadas: A New Approach. Montreal and Kingston: McGill-Queen's University Press, 1988.

Emery, George. Principles and Gerrymanders: Parliamentary Redistribution of Ridings in Ontario, 1840-1954. Montreal and Kingston: McGill-Queen's University Press, 2015.

Emmons, David. The Butte Irish: Class and Ethnicity in an American Mining Town, 18751925. Urbana and Chicago: University of Illinois Press, 1990.

Erdozai, Dominic. "The Secularization of Sin in the Nineteenth Century." Journal of Ecclesiastical History 62.1 (2011): 59-88.

Eriksen, Sidsel. "The Making of the Danish Liberal Drinking Style: The Construction of a 'Wet' Alcohol Discourse in Denmark." Contemporary Drug Problems, 20.1 (Spring 1993): $1-31$.

Errington, Elizabeth Jane. Emigrant Worlds and Transatlantic Communities: Migration to Upper Canada in the First Half of the Nineteenth Century. Montreal and Kingston: McGillQueen's University Press, 2007.

Ferry, Darren. Uniting in Measures of Common Good: The Construction of Liberal Identities in Central Canada, 1830-1900. Montreal and Kingston: McGill-Queen's University Press, 2008.

Fichter, James. "The British Empire and the American Atlantic on Tristian da Cunha, 181116." Journal of Imperial and Commonwealth History 36.4 (2008): 567-589.

Flemming, David B. "WALSH, WILLIAM," in Dictionary of Canadian Biography, vol. 8, University of Toronto/Université Laval, 2003-, accessed June 16, 2014, http://www.biographi.ca/en/bio/walsh_william_8E.html.

Fletcher, Holly Berkley. Gender and the American Temperance Movement. New York and 
London: Routledge, 2008.

Florin, Paul, Eric Jones, Abraham Wandersman, "Black Participation in Voluntary Associations." Nonprofit and Voluntary Sector Quarterly 15, no. 1 (January 1986): 65-86.

Foner, Nancy. "What's New About Transnationalism: New York Immigrants Today and at the Turn of the Century." Diaspora 6 (1997): 355-375.

_ _ _ "Then and Now or Then to Now: Immigration in New York in Contemporary and Historical Perspective." In Immigration, Incorporation and Transnationalism, edited by Elliott Barkan, 25-38. New Brunswick and London: Transaction Publishers, 2007.

Forster, Ben. "MACKENZIE, ALEXANDER," in Dictionary of Canadian Biography, vol. 12, University of Toronto/Université Laval, 2003-, accessed March 1, 2016, http://www.biographi.ca/en/bio/mackenzie_alexander_12E.html.

Foucault, Michel. "Governmentality." In The Foucault Effect: Studies in Governmentality. Edited by Graham Burchell, Colin Gordon, and Peter Miller, 87-104. Chicago: University of Chicago Press, 1991.

Friedrich, Carl J. and Zbigniew K. Brzezinski, Totalitarian Dictatorship and Autocracy. Cambridge: Harvard University Press, 1965.

Gans, Herbert J. "Ethnic Invention and Acculturation: A Bumpy-Line Approach.” Journal of American Ethnic History 12.1 (1992): 45-52.

Gerber, David, Bruce Elliott, Suzanne Sinke editors, Letters Across Borders: The Epistolary Practices of International Migrants. New York: Palgrave Macmillian, 2006.

Giddens, Anthony. Class Structure of the Advanced Societies. London: Hutchinson, 1973.

Glazer, Nathan and Daniel P. Moynihan. Beyond the Melting Pot: The Negroes, Puerto Ricans, Jews, Italians, and Irish of New York City. Cambridge: M.I.T. Press and Harvard University Press, 1963.

Glazer, Nathan. "Is Assimilation Dead?" The Annals of the American Academy of Social and Political Sciences 530 (1993): 122-136.

Gleeson, David T. ed. The Irish in the Atlantic World. University of South Carolina Press, 2010 .

Glick-Schiller, Nina, Linda Basch, Cristina Blanc-Szanton. "Transnationalism: A New Analytical Framework for Understanding Migration.” In Toward a Transnational Perspective on Migration, edited by Nina Glick-Schiller, Linda Basch, Cristina BlancSzanton, 1-24. New York: New York Academy of Sciences, 1992.

Goheen, Peter G. "Symbols in the Streets: Parades in Victorian Urban Canada." Urban 
History Review, Vol. 18, no, 3 (February 1990): 237-243.

Gordon, Beverly. Bazaars and Fair Ladies: The History of the American Fundraising Fair. Knoxville: University of Tennessee Press, 1998.

Gordon, Milton. Assimilation in American Life. New York: Oxford University Press, 1964.

Grace, Robert. "Irish Immigration and Settlement in a Catholic City: Quebec, 1842-61." Canadian Historical Review 84.2 (June 2003): 217-251.

Greer, Allan and Ian Radforth, Colonial Leviathan: State Formation in Mid-nineteenthcentury Canada. Toronto: University of Toronto Press, 1992.

Grob-Fitzgibbon, Benjamin. "The Curious Case of the Vanishing Debate over Irish Home Rule: The Dominion of Canada, Irish Home Rule, and Canadian Historiography." American Review of Canadian Studies Vol. 45, No. 1, 125 (2015): 113-128.

Gusfield, Joseph. Symbolic Crusade: Status Politics and the American Temperance Movement. Urbana: University of Illinois Press, 1963.

Habermas, Jurgen. The Structural Transformation of the Public Sphere: An Inquiry Into a Category of Bourgeois Society. Translated by Thomas Burger with the assistance of Frederick Lawrence. Cambridge: MIT Press, 1989.

Hale, Henry. "Explaining Ethnicity." Comparative Political Studies, Volume 37, no.4 (May 2004): 458-485.

Hall, Catherine. Civilizing Subjects: Metropole and Colony in the English Imagination 1830-1867. Chicago: University of Chicago Press, 2002.

Handlin, Oscar. Boston's Immigrants, 1790-1865: A Study in Acculturation. Cambridge: Harvard University Press, 1941.

_ _ - The Uprooted. Boston and Toronto: Little, Brown and Company, 1951.

Harrison, Brian. Drink and the Victorians: The Temperance Question in England: 1815 1872. Pittsburgh: University of Pittsburgh Press, 1971.

Hastings, Paula. "Our Glorious Anglo-Saxon Race Shall Ever Fill Earth's Highest Place: The Anglo-Saxon and the Construction of Identity in Late-Nineteenth-Century Canada." In Canada and the British World: Culture, Migration, and Identity, edited by Phillip Buckner and R. Douglas Francis, 92-110. Vancouver: UBC Press, 2006.

Heaman, E.A. "Rights Talk and the Liberal Order Framework." In Liberalism and Hegemony: Debating the Canadian Liberal Revolution, edited by Jean-François Constant and Michel Ducharme, 147-175. Toronto: University of Toronto Press, 2009. 
_ _ - A Short History of the State in Canada. Toronto: University of Toronto Press, 2015.

Heney, John J. John Heney \& Son: The Saga of an Ottawa Irish Family. Renfrew: General Store Publishing House, 2010.

Heron, Craig. Working in Steel: The Early Years in Canada, 1883-1935. Toronto:

McClelland and Stewart; 1988.

__ _ _ Booze: A Distilled History. Toronto: Between the Lines, 2003.

Holman, Andrew. A Sense of Their Duty: Middle-Class Formation in Victorian Ontario Towns. Montréal: McGill-Queen's University Press, 2000.

Houston, Cecil and William Smyth. Irish Emigration and Canadian Settlement: Patterns, Links, and Letters. Toronto and Buffalo: University of Toronto Press, 1990.

Howe, Stephen. Ireland and Empire: Colonial Legacies in Irish History and Culture. Oxford: Oxford University Press, 2000.

_ _ _ _ "Minding the Gaps: New Directions in the Study of Ireland and Empire." Journal of Imperial and Commonwealth History 37.1 (2009): 135-149.

Humphries, Charles W. "LYNCH, JOHN JOSEPH," in

EN:UNDEF:public_citation_publication, vol. 11, University of Toronto/Université Laval, 2003-, accessed March 10, 2016,

http://www.biographi.ca/en/bio/lynch_john_joseph_11E.html.

Hunt, Alan. Governing Morals: A Social History of Moral Regulation. Cambridge:

Cambridge University Press, 1999.

Hutcheson Jr., John D. and Lino H. Dominguez. "Ethnic Self-Help Organizations in NonBarrio Settings: Community Identity and Voluntary Action." Nonprofit and Voluntary Sector Quarterly 15, no. 4, (October 1986): 13-22.

Iacovetta, Franca. Gatekeepers: Reshaping Immigrant Lives in Cold War Canada. Toronto: Between the Lines Press, 2006.

Ignatiev, Noel. How the Irish Became White. New York: Routledge, 1995.

Isin, Engin F. and Patricia K. Wood. Citizenship and Identity. London: Sage Publications, 1999.

Jackson, Alvin. Home Rule: An Irish History, 1800-2000. Oxford: Oxford University Press, 2003

Jackson, James. "The Radicalization of the Montreal Irish: The Role of The Vindicator." Canadian Journal of Irish Studies 31, no. 1 (Spring 2005): 90-97. 
James, Kevin. "Dynamics of Ethnic Associational Culture in a Nineteenth-Century City: Saint Patrick's Society of Montreal, 1834-56." Canadian Journal of Irish Studies 26, no.1 (2000): 47-67.

Jeffers, Leo W. "Ethnicity and Ethnic Media Use: A Panel Study," Communication Research 27, no. 4 (2000): 496-535.

Jeffrey, Edith. "Reform, Renewal, and Vindication: Irish Immigrants and the Catholic Total Abstinence Movement in Antebellum Philadelphia," The Pennsylvania Magazine of History and Biography, 112, no. 3 (July 1988): 407-431.

Jeffrey, Keith. "Distance and Proximity in Service to the Empire: Ulster and New Zealand between the Wars." Journal of Imperial and Commonwealth History 36.3 (2008): 453-472.

Jenkins, Brian. The Fenian Problem: Insurgency and Terrorism in a Liberal State, 18581874. Montreal and Kingston: McGill-Queen's University Press, 2008.

Jenkins, William. "Deconstructing Diasporas: Networks and Identities Among the Irish in Buffalo and Toronto. 1870-1910." Immigrants and Minorities Volume 23 Issue 2-3 (2005): 359-398.

_ _ _ . "Remapping 'Irish America': Circuits, Places, Performances." Journal of American Ethnic History 28.4 (2009): 90-99.

_ _ _ Between Raid and Rebellion: The Irish in Buffalo and Toronto, 1867-1914. Montreal and Kingston: McGill-Queen's University Press, 2013.

Jensen, Richard. “'No Irish Need Apply:' A Myth of Victimization,” Journal of Social History, 36, no. 2 (Winter 2002): 405-429.

Jess, Raymond. "Re-centering the Periphery: The Protestant Irish of Montreal and the Birth of Canadian National Identity.” (MA Thesis, Concordia University, 2013).

Johnson, Paul E. A Shopkeeper's Millennium: Society and Revivals in Rochester, New York, 1815-1837. New York: Hill and Wang, 1978.

Johnston, A.A. A History of the Catholic Church in Eastern Nova Scotia Vol.1, 1611-1827. Antigonish: St Francis Xavier University Press, 1960.

_ _ _ A History of the Catholic Church in Eastern Nova Scotia Vol 2, 1827-1880.

Antigonish: St Francis Xavier University Press, 1971.

Jones, Aled. "The Nineteenth Century Media and Welsh Identity." In Nineteenth-Century Media and the Construction of Identities, edited by Laurel Brake, Bill Bell, David Finkelstein, 310-325. Hampshire and New York: Palgrave, 2000. 
Jones, Martin, Rhys Jones, Michael Woods, Mark Whitehead, Deborah Dixon, Matthew Hannah, An Introduction to Political Geography: Space, Place and Politics, Second Edition. London and New York: Routledge, 2015.

Kealey, Gregory. Toronto Workers Respond to Industrial Capitalism, 1860-1892. Toronto: University of Toronto Press, 1980.

Kehoe, S. Karly. "Accessing Empire: Irish Surgeons and the Royal Navy, 1840-1880," Social History of Medicine 26, no. 2 (2013): 204-224.

Kelleher, Patricia. "Class and Catholic Irish Masculinity in Antebellum America: Young Men on the Make in Chicago." Journal of American Ethnic History 28.4 (2009): 7-42.

Kelly, Matthew. "Irish Nationalist Opinion and the British Empire in the 1850s and 1860s." Past and Present 204 (August 2009): 127-154.

Kennedy, Catriona "'A Gallant Nation': Chivalric Masculinity and Irish Nationalism in the 1790s." In Public Men: Masculinities and Politics in Modern Britain, edited by Matthew McCormack, 73-92. London: Palgrave Macmillan, 2007.

Kennedy, Liam. Colonialism, Religion and Nationalism in Ireland. Belfast: Institute of Irish Studies, 1996.

Kenny, Kevin ed. New Directions in Irish-American History. Madison: University of Wisconsin Press, 2003.

_ _ _ Ireland and the British Empire. Oxford: Oxford University Press, 2004.

_ _ _ . "Twenty Years of Irish American Historiography." Journal of American Ethnic History 28.4 (2009): 67-75.

Keough, Willeen. The Slender Thread: Irish Women on the Southern Avalon, 1750-1860. New York: Columbia Press, 2008.

Kiberd, Declan. Inventing Ireland: The Literature of the Modern Nation. Cambridge: Harvard University Press, 1997.

Kibler, M. Alison. "Pigs, Green Whiskers, and Drunken Widows: Irish Nationalists and the 'Practical Censorship' of McFadden's Row of Flats in 1902 and 1903." Journal of American Studies 42 (2008): 489-514.

King, Jason and Kevin James. "Introduction.” Canadian Journal of Irish Studies 31 (2005): 14-17.

Kinzer, Bruce. England's Disgrace: J.S. Mill and the Irish Question. Toronto Buffalo London: University of Toronto Press, 2001. 
Kivisto, Peter. "The Transplanted Then and Now: The Reorientation of Immigration Studies From the Chicago School to the New Social History." Ethnic and Racial Studies 13.4 (1990): 455-481.

_ _ _ " "Theorizing Transnational Immigration: A Critical Review of Current Efforts." Ethnic and Racial Studies 24:4 (2001): 549-577.

Lambert, David and Alan Lester. Colonial Lives across the British Empire: Imperial Careering in the Long Nineteenth Century. Cambridge: Cambridge University Press, 2006.

Langton, Stuart. "The New Voluntarism," Nonprofit and Voluntary Sector Quarterly 10, no. 1 (January 1981): 7-20.

Laqueur, Thomas. "Bodies, Death, and Pauper Funerals." Representations 1, no. 1 (1983): 109-131.

Larkin, Emmet. "The Devotional Revolution in Ireland, 1850-1875." American Historical Review 77, no. 3 (June 1972): 625-52.

Layng, Anthony. "Voluntary Associations and Black Ethnic Identity.” Phylon, 39, no. 2 (1978): 171-179.

Leslie, John F. "The Indian Act: An Historical Perspective.” Canadian Parliamentary Review 25.2 (2002): 23-27.

Levitt, Peggy, Josh De Wind, Steven Vertovec. "International Perspectives of Transnational Migration: An Introduction. International Migration Review 37.3 (Fall 2003): 565-575.

Lopata, Helen Znaniecki. "The Functions of Voluntary Associations in an Ethnic Community: 'Polonia'." In Contributions to Urban Sociology, edited by Ernest W. Burgess and Donald J. Bogue, 203-223. Chicago: University of Chicago Press, 1964.

Lower, Arthur R. M. Colony to Nation: A History of Canada. Don Mills, Ontario: Longmans Canada Limited, 1946.

Lynne, D.C. "Irish-Canadian Financial Contributions to the Home Rule Movement in the 1890s." Studia Hibernica 7 (1967): 182-206.

Mac Laughlin, Jim. "Pestilence on Their Backs, Famine in Their Stomachs: The Racial Construction of Irishness and the Irish in Victorian Britain." In Ireland and Cultural Theory: The Mechanics of Authenticity, edited by Colin Graham and Richard Kirkland, 50-76. London: Macmillian Press, 1999.

Malcolm, Elizabeth. Ireland Sober, Ireland Free: Drink and Temperance in $19^{\text {th }}$ Century Ireland. Syracuse: Syracuse University Press, 1986.

Mannion, John. Irish Settlements in Eastern Canada: A Study of Cultural Transfer and 
Adaptation. Toronto: University of Toronto Press, 1974.

Marks, Lynne. Revivals and Roller Rinks: Religion, Leisure, and Identity in Late Nineteenth Century Small Town Ontario. Toronto: University of Toronto Press, 1996.

Marshall, P.J. “Transatlantic Protestantism and American Independence.” Journal of Imperial and Commonwealth History 36.3 (2008): 345-362.

Martin, Scott. Devil of the Domestic Sphere: Temperance, Gender, and Middle-class Ideology, 1800-1860. DeKalb, Illinois: Northern Illinois University Press, 2008.

Mattingly, Carol. Well-Tempered Women: Nineteenth Century Temperance Rhetoric. Carbondale and Edwardsville: Southern Illinois University Press: 1998.

McCormack, Matthew ed. Public Men: Masculinity and Politics in Modern Britain. New York: Palgrave Macmillian, 2007.

McDannell, Colleen. "True Men As We Need Them: Catholicism and the Irish-American Male.” American Studies 27, no. 4 (1986): 19-33.

McDevitt, Patrick F. "Muscular Catholicism: Nationalism, Masculinity and Gaelic Team Sports, 1884-1916.” Gender and History, Vol 9, no. 2 (August 1997): 262-284.

McDonough, Terrance ed. Was Ireland a Colony? Economics, Politics, and Culture $n$ Nineteenth Century Ireland. Dublin: Irish Academic Press, 2005.

McGowan, Mark. "SMITH, Sir FRANK," in Dictionary of Canadian Biography, vol. 13, University of Toronto/Université Laval, 2003-, accessed March 1, 2016, http://www.biographi.ca/en/bio/smith_frank_13E.html.

_ _ _ The Waning of the Green: Catholics, The Irish, and Identity in Toronto, 1887-1922. Montreal and Kingston: McGill-Queen's University Press, 1999.

_ _ _ Michael Power: The Struggle to Build the Catholic Church on the Canadian Frontier. Montreal and Kingston, McGill-Queen's University Press, 2005.

_ _ _ Creating Canadian Historical Memory: The Case of the Famine Migration of 1847. Canada's Ethnic Group Series, Booklet No.30. Canadian Historical Association: Ottawa, 2006.

McGrath, Thomas C. "The Tridentine Evolution of Modern Irish Catholicism, 1563-1962: A Re-examination of the 'Devotional Revolution' Thesis." Recusant History, 20, no. 4, (October 1991): 512-523.

McKay, Ian. "The Liberal Order Framework: A Prospectus for a Reconnaissance of Canadian History.” Canadian Historical Review 81, no. 4 (2000): 617-645. 
_ _ _ . "Canada as a Long Liberal Revolution: On Writing the History of Actually Existing Canadian Liberalisms, 1840s-1940s." In Liberalism and Hegemony: Debating the Canadian Liberal Revolution, edited by Jean-François Constant and Michel Ducharme. Toronto: University of Toronto Press, 2009. 347-452.

McKibben, Sarah E. "Speaking the Unspeakable: Male Humiliation and Female National Allegory After Kinsale," Eire-Ireland 43: 3\&4 (Fall/Winter 2008): 11-30.

McLaughlin, Robert. Irish Canadian Conflict and the Struggle for Irish Independence: 1912-1925. Toronto: University of Toronto Press, 2013.

McMahon, Cian T. "Caricaturing Race and Nation in the Irish American Press, 1870-1880: A Transnational Perspective," Journal of American Ethnic History 33, no. 2 (Winter 2014): $33-56$.

McManus, Shelia. The Line Which Separates: Race, Gender, and the Making of the AlbertaMontana Borderlands. Edmonton: University of Alberta Press, 2005.

McNairn, Jeffrey. The Capacity to Judge: Public Opinion and Deliberative Democracy in Upper Canada, 1791-1854. Toronto: University of Toronto Press, 2000.

Meagher, Timothy. "From the World to the Village and the Beginning to the End and After: Research Opportunities in Irish American History." Journal of American Ethnic History 28.4 (2009): 118-135.

Mehta, Uday Singh. Liberalism and Empire: A Study in Nineteenth-Century British Thought. Chicago: University of Chicago Press, 1999.

Mill, John Stuart. On Liberty. Boston: Ticknor and Fields, 1863.

Miller, J.R. "Anti-Catholicism in Canada from the British Conquest to the Great War." In Creed and Culture: The Place of English-Speaking Catholics in Canadian Society, 17501930, edited by Terrence Murphy and Gerald Stortz, 25-48. Montreal and Kingston: McGillQueen's University Press, 1993.

Miller, Kerby. Emigrants and Exiles: Ireland and the Irish Exodus to North America. New York and Oxford: Oxford University Press, 1985.

_ - _. Ireland and Irish America: Culture, Class, and Transatlantic Migration. Dublin: Field Day, 2008.

_ _ _ . "'Heirs of Freedom' or 'Slaves to England'? Protestant Society and Unionist Hegemony in Nineteenth Century Ulster.” Radical History Review 104 (Spring, 2009): 1740 .

Moloney, Deidre. American Catholic Lay Groups and Transatlantic Social Reform in the Progressive Era. Chapel Hill and London: University of North Carolina Press, 2002. 
_ _ _ . "Land League Activism in Transnational Perspective," US Catholic Historian 22, no. 3 (Summer 2004): 61-74.

_ _ _ . "Who's Irish? Ethnic Identity and Recent Trends in Irish American History." Journal of American Ethnic History 28.4 (2009): 100-109.

Monahan, Arthur J. "Bishop Farrell of Hamilton as a Participant in the Political Life of his Day", Canadian Catholic Historical Association, Report 27 (1960): 25-34.

Moore, Julia. "The Sisters of St Joseph: Beginnings in London Diocese, 1868-1878." CCHA Study Sessions, 45 (1978): 37-55.

Morawska, Ewa. "In Defence of the Assimilation Model," Journal of American Ethnic History 13.2, (1994) 76-86.

Morgan, Hiram. "An Unwelcome Heritage: Ireland's Role in British Empire-Building." History of European Ideas 19 (1994): 619-625.

Morris, Raymond. "British and American Research on Voluntary Associations: A Comparison.” Sociological Inquiry, 35 (Spring 1965): 186-200.

Morton, Desmond. Ministers and Generals: Politics and the Canadian Militia, 1868-1904. Toronto: University of Toronto Press, 1971.

Morton, Graeme and David A. Wilson. Irish and Scottish Encounters With Indigenous Peoples: Canada, the United States, New Zealand, and Australia. Montreal; Kingston: McGill-Queen's University Press, 2014.

Morton, Frederick Lee. "Judicial Recruitment and Selection." In Law, Politics, and the Judicial Process in Canada, edited by Frederick Lee Morton, 117-132. Calgary: University of Calgary Press, 2002.

Moyer, Mel S. "Voluntary Action Research: A View From Canada." Nonprofit and Voluntary Sector Quarterly 14, no. 2-3, (April 1985): 15-16.

Mullan, Michael L. "Sport, Culture, and Nation Among the Hibernians of Philadelphia: Irish American Civic Engagement and Cultural Nationalism, 1880-1920." Journal of Urban History 39 (2013): 579-600.

Murphy, Terrence. "Trusteeism in Atlantic Canada: The Struggle for Leadership Among the Irish Catholics of Halifax, St John's, and Saint John, 1780-1850." In Creed and Culture: The Place of English-Speaking Catholics in Canadian Society, 1750-1930, edited by Terrence Murphy and Gerald Stortz, 126-151. Montreal and Kingston: McGill-Queen's University Press, 1993.

_ _ _ . "Transformation and Triumphialism: The Irish Catholics of Halifax, 1839-1858," 
Unpublished paper delivered at CCHA Conference 2014.

Myrdal, Gunnar with the assistance of Richard Sterner and Arnold Rose. An American Dilemma: Two Volumes. New York: Harper, 1940.

Neswald, Elizabeth. "'The Benefits of a Mechanics' Institute and the Blessing of Temperance': Science and Temperance in 1840s Ireland." Social History of Drugs and Alcohol 22.2 (Spring 2008): 209-227.

Nicholson, Murray W. "Bishop Charbonnel: The Beggar Bishop and the Origins of Catholic Social Action." CCHA Historical Studies, 52 (1985), 51-66.

Noel, Jan. "Dry Patriotism: The Chiniquy Crusade." Canadian Historical Review 71, (June 1990): 189-207.

_ _ _ Canada Dry: Temperance Crusades before Confederation. Toronto and Buffalo: University of Toronto Press, 1995.

Noel, S.J.R. Patrons, Clients, Brokers: Ontario Society and Politics, 1791-1896. Toronto: University of Toronto Press, 1990.

Nolan, Janet. "Women's Place in the History of the Irish Diaspora: A Snapshot." Journal of American Ethnic History 28.4 (2009): 76-81.

O'Brien, Conor Cruise. Parnell and His Party, 1880-90. Oxford: Clarendon Press, 1957.

O'Brien, John. The Men of '38 and Other Pioneer Priests. Kilmore: Lowden Publishing Co., 1975.

O'Day, Alan. Irish Home Rule, 1867-1921. Manchester: Manchester University Press, 1998.

O'Leary, Paul. "Networking Respectability: Class, Gender and Ethnicity among the Irish in South Wales, 1845-1914." Immigrants and Minorities 23.2-3 (2005): 255-275.

O hAnnrachain, Tadhag. "The Consolidation of Irish Catholicism Within a Hostile Imperial Framework: A Comparative Study of Early Modern Ireland and Hungary.” In Empires of Religion edited by Hilary M. Carey, 25-42. London: Palgrave Macmillan, 2008.

Oliver, Peter. "McCROSSON, THOMAS," in Dictionary of Canadian Biography, vol. 13, University of Toronto/Université Laval, 2003-, accessed March 1, 2016, http://www.biographi.ca/en/bio/mccrosson_thomas_13E.html.

Olson, Sherry and Patricia Thornton. Peopling the North American City: Montreal, 18401900. Montreal; Ithica: McGill-Queen's University Press, 2011.

Palmer, Bryan. Working-Class Experience: Rethinking the History of Canadian Labour, 1800-1991. Toronto: McClelland and Stewart, 1992. 
Pentland, H.C. Labour and Capital in Canada, 1650-1860. Toronto: Lorimer, 1981.

_ _ _ . "The Lachine Strike of 1843." Canadian Historical Review 29 (September 1948): $255-277$.

Park, Richard. "Assimilation, Social.” In Encyclopedia of the Social Sciences, edited by E. Seligman and A. Johnson, 281-283. New York: Macmillan, 1930.

Perin, Roberto. Rome in Canada: The Vatican and Canadian Affairs in the Late Victorian Age. Toronto: University of Toronto Press, 1990.

Perry, Adele. Edge of Empire: Gender, Race, and the Making of British Columbia, 18491871. Toronto: University of Toronto Press, 2001.

_ _ _ “Women, Racialized People, and The Making of the Liberal Order." In Liberalism and Hegemony: Debating the Canadian Liberal Revolution, Jean-Francois Constant and Michel Ducharme, eds. 274-297. Toronto: University of Toronto Press, 2009.

Pitts, Jennifer. A Turn to Empire: The Rise of Imperial Liberalism in Britain and France. Princeton and Oxford: Princeton University Press, 2005.

Pocock, J.A. "British History: A Plea for a New Subject," The Journal of Modern History 47.4 (1975): 601-621.

Pooley, Colin G. "Segregation or Integration? The Residential Experience of the Irish in Mid-Victorian Britain.” In The Irish in Britain, 1815-1939, edited by Roger Swift and Sheridan Gilley, 60-83. London: Pinter, 1989.

Portes, Alejandro. "Conclusion: Theoretical Convergencies and Empirical Evidence in the Study of Immigrant Transnationalism." International Migration Review 37.3 (Fall, 2003): 874-892.

Poulter, Gillian. Review of Uniting in Measures of Common Good: The Construction of Liberal Identities in Central Canada, (McGill-Queen's University Press, 2008) by Darren Ferry. Labour/Le Travail 65 (Spring/Printemps 2010): 192-194.

Price, Richard. "One Big Thing: Britain and its Empire.” Journal of British Studies 43.3 (2006): 602-627.

Quinn, John F. “Father Mathew's American Tour,” Éire-Ireland 30 (Spring1995): 91-104.

_ _ _ Father Mathew's Crusade: Temperance in Nineteenth-Century Ireland and Irish America. Amherst and Boston: University of Massachusetts Press, 2002.

Racine, Karen. "Rum, Recruitment, and Revolution: Alcohol and the British and Irish Legions in Columbia's War for Independence, 1817-1823." Irish Migration Studies in Latin 
America 4.2 (2006): 45-53.

Rafferty, Oliver. "Fenianism in North America in the 1860s: The Problems for Church and State," History 84.274 (April 1999): 257-277.

Roberts, Julia. In Mixed Company: Taverns and Public Life in Upper Canada. Vancouver, UBC Press, 2009.

Roby, Yves. "CHINIQUY, CHARLES," in Dictionary of Canadian Biography, vol. 12, University of Toronto/Université Laval, 2003-, accessed March 21, 2016, http://www.biographi.ca/en/bio/chiniquy_charles_12E.html.

Roediger, David. The Wages of Whiteness: Race and the Making of the American Working Class. London; New York: Verso, 1991.

Rose, Arnold. Theory and Method in the Social Sciences. Minneapolis: University of Minnesota Press, 1954.

Ross, Jack C. An Assembly of Good Fellows: Voluntary Associations in History. Westport, Connecticut: Greenwood Press, 1976.

Ryan, Mary P. The Cradle of the Middle-Class: The Family in Oneida County, New York, 1790-1865. Cambridge, Eng: Cambridge University Press, 1981.

Ryder, Sean. "Defining Colony and Empire in Early Nineteenth Century Nationalism." In Was Ireland a Colony, edited by Terrence McDonough, 165-185. Dublin: Irish Academic Press, 2005.

See, Scott W. Riots in New Brunswick: Orange Nativism and Social Violence in the 1840s. Toronto and Buffalo: University of Toronto Press, 1993.

Semple, Rhonda A. "Missionary Manhood: Professionalism, Belief and Masculinity in the Nineteenth-Century British Imperial Field." Journal of Imperial and Commonwealth History 36.3 (2008): 397-415.

Senior, Hereward. The Last Invasion of Canada: the Fenian Raids, 1866-1870. Ottawa: Dundurn Press, 1991.

Shepard, George. "'God Save the Green' Fenianism and Fellowship in Victorian Ontario," Histoire Sociale/Social History, 20 (1987): 129-144.

Shiell Annette, Fundraising, Flirtation, and Fancywork: Charity Bazaars in Nineteenth Century Australia. Newcastle: Cambridge Scholars Publishing, 2014.

Shiman, Lillian Lewis. “John B. Gough: Trans-Atlantic Temperance Orator.” Social History of Alcohol Review 15.3-4 (2001): 20-29. 
Sills, David. "Voluntary Associations: Sociological Aspects." In International Encyclopedia of the Social Sciences, Volume 16, edited by David Sills, 363-376. New York: Macmillan and Free Press, 1968.

Smith, Andrew. British Businessmen and Canadian Confederation: Constitution Making in an Era of Anglo-Globalization. Montreal and Kingston: McGill-Queen's University Press, 2008.

Smith, Anthony. Ethnosymbolism and Nationalism: A Cultural Approach. London:

Routledge, 2009.

Smith, Constance and Anne Freedman. Voluntary Associations: Perspectives on the Literature. Cambridge: Harvard University Press, 1972.

Smith, Michael Peter and Luis Guarnizo, ed. Transnationalism From Below. New Brunswick and London: Transaction Publishers, 1998.

Smithey, Lee A. and Michael P. Young. "Parading Protest: Orange Parades in Northern Ireland and Temperance Parades in Antebellum America." Social Movement Studies 9.4 (2010): 393-410.

Smyth, William J. Toronto, The Belfast of Canada: The Orange Order and the Shaping of Municipal Culture. Toronto: University of Toronto Press, 2015.

Stacey, C.P. “A Fenian Interlude: The Story of Michael Murphy,” Canadian Historical Review 15, no. 2 (June 1934): 133-154.

Sternbeck, Michael. The Catholic Church in Singleton: An Historical Look at its People and Progress. Broadmeadow: Newey and Beath Printers, 1981.

Steward, Patrick and Bryan P. McGovern. The Fenians: Irish Rebellion in the North Atlantic World. University of Tennessee Press: 2013.

Stewart, Gordon. "Political Patronage Under Macdonald and Laurier, 1878-1911." American Review of Canadian Studies Volume 10, Issue 1 (1980): 3-26.

Stillar, Alan. "JAMOT. JEAN-FRANCOIS," in Dictionary of Canadian Biography, vol. 11, University of Toronto/Universite Laval, 2003-, accessed June 18, 2015, http://www.biographi.ca/en/bio/jamot_jean_francois_11E.html

Stortz, G.J. "The Irish Catholic Press in Toronto, 1874-1887.” CCHA Study Sessions, 47 (1980): 42-56.

Strange, Julie-Marie. "Only a Pauper Whom Nobody Owns: Reassessing the Pauper Grave, c. 1880-1914.” Past \& Present 178 (2003): 148-175.

Sutherland, David A.“KENNY, THOMAS EDWARD.” In Dictionary of Canadian 
Biography, vol. 13, University of Toronto/Université Laval, 2003-, accessed April 7, 2016, http://www.biographi.ca/en/bio/kenny_thomas_edward_13E.html.

Swift, Roger and Christine Kinealy, eds. Politics and Power in Victorian Ireland. Dublin and Portland: Four Courts Press, 2006.

Thompson, E.P. The Making of the English Working-Class. New York: Oxford University Press, 1966.

Thompson, Scott and Gary Genosko. Punched Drunk: Alcohol, Surveillance, and the LCBO, 1927-1975. Halifax, Fernwood Press, 2009.

Thomson, Andrew. "The Sentinel and Orange and Protestant Advocate, 1877-1896: An Orange View of Canada.” (M.A. Thesis, Wilfrid Laurier University), http://scholars.wlu.ca/etd/10;

Toner, Peter M. "The Home Rule League in Canada: Fortune, Fenians, and Failure." Canadian Journal of Irish Studies 15, no. 1 (1989): 7-19.

_ _ _ . "The Fanatic Heart of the North." In Irish Nationalism in Canada, edited by David A. Wilson, 34-51. Montreal and Kingston: McGill-Queen's University Press, 2009.

Tosh, John and Michael Roper ed. Manful Assertions: Masculinities in Britain Since 1800. London and New York: Routledge, 1991.

Tosh, John. A Man's Place: Masculinity and the Middle-Class Home in Victorian England. New Haven and London: Yale University Press, 1999.

_ _ _ Manliness and Masculinities in Nineteenth Century Britain. Harlow: Pearson Education Limited, 2005.

Townend, Paul A. Father Mathew, Temperance and Irish Identity. Dublin: Irish Academic Press, 2002.

_ _ _ _ "Between Two Worlds: Irish Nationalists and Imperial Crisis, 1878-1880." Past and Present 194 (February 2007): 139-174.

_ _ _ . "Matthewite Temperance in Atlantic Perspective." In The Irish in the Atlantic World edited by David T. Gleeson. University of South Carolina Press, 2010, 19-37.

Toye, Richard. "'Phrases Make History Here': Churchill, Ireland and the Rhetoric of Empire.” Journal of Imperial and Commonwealth History 38.4 (2010): 549-570.

Treudly, Mary Bosworth. "Formal Organization and the Americanization Process with Special Reference to the Greeks of Boston." American Sociological Review 14 (February 1949): 44-53.

Trigger, Rosalyn. "Irish Politics on Parade: The Clergy, National Societies, and St Patrick's 
Day Processions in Nineteenth-century Montreal and Toronto." Histoire Sociale/Social History, Vol. 37, no. 74 (2004): 159-199.

_ _ _ . "Clerical Containment of Diasporic Nationalism." In Irish Nationalism in Canada, edited by David Wilson. Montreal and Kingston: McGill-Queen's University Press, 2009: 82-96.

Tulchinsky, Gerald J.J., and Alan R. Dever, "RYAN, THOMAS," in Dictionary of Canadian Biography, vol. 11, University of Toronto/Université Laval, 2003-, accessed January 6, 2014, http://www.biographi.ca/en/bio/ryan_thomas_11E.html

Valverde, Mariana. The Age of Light, Soap, and Water: Moral Reform in English Canada, 1885-1925. Toronto: McClelland and Stewart, 1991.

Vargas, Mark A. "The Progressive Agent of Mischief: The Whiskey Ration and Temperance in the United States Army.” Historian 67.2 (2005): 199-216.

Vertovec, Steven. "Conceiving and Researching Transnationalism." Ethnic and Racial Studies 22.2 (1999): 447-462.

_ _ _ Transnationalism. London and New York: Routledge, 2009.

Waite, P.B. "BOWELL, Sir MACKENZIE," in Dictionary of Canadian Biography, vol. 14, University of Toronto Press/Universite Laval, 2003-, accessed June 18 2015, http://www.biographi.ca/en/bio/bowell_mackenzie_14.html.

Wall, Maureen. "The Rise of a Catholic Middle-Class in Eighteenth Century Ireland," Irish Historical Studies, 11, no. 42 (September 1958): 91-115.

__ _ . The Penal Laws, 1691-1760. Dundalk: Dundalgan Press, 1967.

Walsh, Victor. “'Drowning the Shamrock': Drink, Teetotalism, and the Irish Catholics of Gilded-Age Pittsburgh," Journal of American Ethnic History, 10, nos. 1/2 (Fall 1990-Winter 1991): 60-79.

Walter, Virginia A. "Children as Citizens in Training: Political Socialization for s Strong Democracy." Nonprofit and Voluntary Sector Quarterly. 19, no. 1 (Spring 1990): 7-20.

Warsh, Cheryl Krasnick. "Dominion Alliance for the Total Suppression of the Liquor Traffic." In Alcohol and Drugs in North America: A Historical Encyclopedia, Vol. 1, edited by David M. Fahey and Jon S. Miller, 228-230. Santa Barbara, California: ABC-CLIO, 2013.

Whelan, Kevin and Tom Power eds., Endurance and Emergence: Catholics in Ireland in the Eighteenth Century. Dublin: Irish Academic Press, 1990.

Whitaker, Reg, Gregory S. Kealey, Andrew Parnaby. Secret Service: Political Policing in 
Canada From the Fenians to Fortress America. Toronto: University of Toronto Press, 2012.

White, Elizabeth Alice. "Charitable Calculation: Fancywork, Charity, and the Culture of the Sentimental Market." In The Middling Sorts: Explorations in the History of the American Middle Class edited by Burton J Bledstein and Robert D. Johnston, 73-85. New York: Routledge, 2001.

Wilson, David A. The Irish in Canada. Canadian Historical Association Booklet: Canada's Ethnic Groups. Ottawa: Canadian Historical Association, 1989.

_ _ — . "The Fenians in Montreal, 1862-1868: Invasion, Intrigue, and Assassination." Eire-Ireland, 34, nos. 13-14, (Fall-Winter 2003): 109-133.

_ _ _ . "The Whiteness of Ireland Under and After the Union. Comment: Whiteness and Irish Experience in North America," The Journal of British Studies 44, no.1 (January 2005): 153-60.

_ _ _ . "Introduction." In Irish Nationalism in Canada, edited by David A. Wilson, 3-21. Montreal and Kingston: McGill-Queen's University Press, 2009.

_ _ — Thomas D'Arcy McGee Volume 2: The Extreme Moderate, 1857-1868. Montreal and Kingston: McGill-Queen's University Press, 2011.

_ _ _ . "The Fenian World of Jeremiah Gallagher." Canadian Journal of Irish Studies, Volume 39, Volume 1 (2015): 21-37.

Wimmer, Andreas. "The Making and Unmaking of Ethnic Boundaries: A Multilevel Process Theory," American Journal of Sociology 113, no. 4 (January 2008): 970-1022.

Wolffe, John. "Anti-Catholicism and the British Empire, 1815-1914," In Empires of Religion edited by Hilary M. Carey, 43-63. London: Palgrave MacMilliam, 2008.

Yeomans, Henry. "What did the British Temperance Movement Accomplish? Attitudes to Alcohol, the Law and Moral Regulation.” Sociology 45.1 (2011): 38-53.

\section{THESES}

Banoub, David. "The Patronage Effect: Civil Service Reforms, Job-Seeking, and State Formation in Victorian Canada." PhD diss., Carleton University, 2013.

FitzGerald, John E. "Conflict and Culture in Irish Newfoundland Roman Catholicism, 18291850." PhD diss., University of Ottawa, 1997.

Fox, Sherwood Dean. "Voluntary Associations and Social Structure.” PhD diss., Harvard 
University, 1952.

Janis, Ely M. "The Land League in the United States and Ireland: Nationalism, Gender and Ethnicity in the Gilded Age.” PhD diss., Boston College, 2008.

Lambert, Carolyn. "Far from the Homes of their Fathers: Irish Catholics in St John's, Newfoundland, 1840-86.” PhD diss., Memorial University, 2010.

Shanahan, David. "The Irish Question in Canada: Ireland, the Irish and Canadian Politics: 1880-1922.” PhD diss., Carleton University, 1989.

Toner, Peter M. “The Rise of Irish Nationalism in Canada, 1858-1884,” PhD diss., National University of Ireland, 1974. 